\title{
Organisasjonsperspektiv på samordning av helse- og velferdstjenester
}

Catharina Bjørkquist og Mona Jerndahl Fineide (red.)

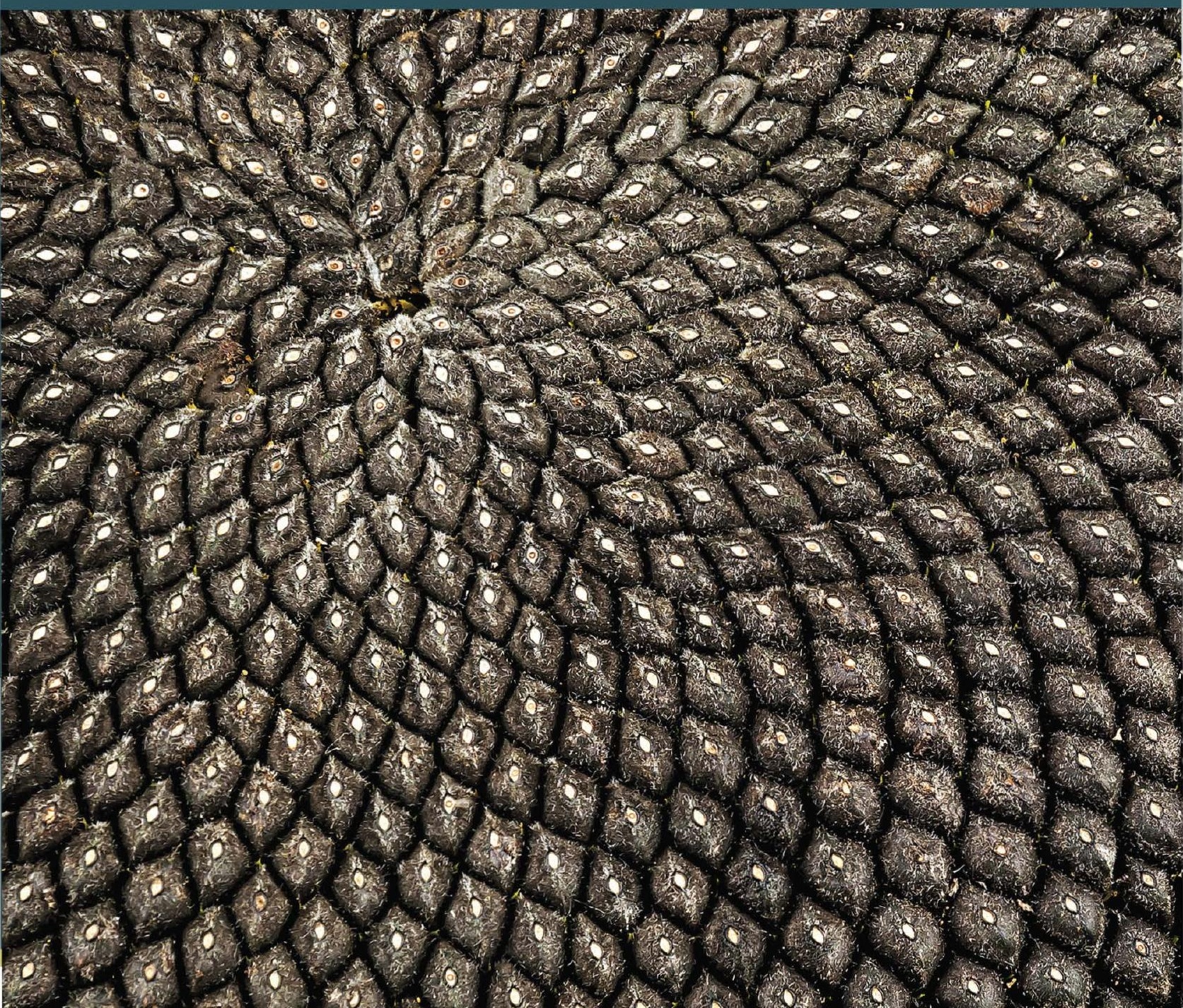
19.2.
잉
9

NOASPP 
Organisasjonsperspektiv på samordning av helse- og velferdstjenester 

Catharina Bjørkquist og Mona Jerndahl Fineide (red.)

\section{Organisasjonsperspektiv på samordning av helse- og velferdstjenester}


(c) 2019 Catharina Bjørkquist, Mona Jerndahl Fineide, Tone Alm Andreassen, Gunnar Vold Hansen, Mia Vabø, Helge Ramsdal, Erlend Vik, Turid Aarseth og Marit K. Helgesen..

Dette verket omfattes av bestemmelsene i Lov om opphavsretten til åndsverk m.v. av 1961. Verket utgis Open Access under betingelsene i Creative Commons-lisensen CC-BY 4.0 (http://creativecommons.org/licenses/by/4.0/). Denne tillater tredjepart å kopiere, distribuere og spre verket i hvilket som helst medium eller format, og å remixe, endre, og bygge videre på materialet til et hvilket som helst formål, inkludert kommersielle, under betingelse av at korrekt kreditering og en lenke til lisensen er oppgitt, og at man indikerer om endringer er blitt gjort. Tredjepart kan gjøre dette på enhver rimelig måte, men uten at det kan forstås slik at lisensgiver bifaller tredjepart eller tredjeparts bruk av verket.

Boka er utgitt med støtte fra Høgskolen i Østfold, Høgskolen i Molde og OsloMet storbyuniversitetet.

ISBN trykt bok: 978-82-02-64593-9

ISBN PDF: 978-82-02-63183-3

ISBN EPUB: 978-82-02-64590-8

ISBN HTML: 978-82-02-64591-5

ISBN XML: 978-82-02-64592-2

DOI: https://doi.org/10.23865/noasp.66

Dette er en fagfellevurdert antologi.

Omslagsdesign: Cappelen Damm AS

Forsidebilde: vovashevchuk/Getty Images. Bildet er brukt med tillatelse fra Getty Images, og er ikke omfattet av CC-BY 4.0-lisens. Bildet kan ikke gjenbrukes uten tillatelse fra Getty Images.

Cappelen Damm Akademisk/NOASP

noasp@cappelendamm.no 


\section{Innhold}

Introduksjon: Behovet for samordning og samarbeid.................................... 7

Catharina Bjørkquist og Mona Jerndahl Fineide

Kapittel 1 Tilnærminger i forskning om samordning og samarbeid 19 Tone Alm Andreassen

Kapittel 2 Organisering av individuell brukermedvirkning 47 Gunnar Vold Hansen

Kapittel 3 Tverrprofesjonelt samarbeid i ulike styringskontekster hverdagsrehabilitering som eksempel .69 Mia Vabø

Kapittel 4 Tverrfaglige team - hvordan lykkes?. .95 Helge Ramsdal

Kapittel 5 Koordinatorordninger som samordningstiltak tre mulige paradokser 119 Erlend Vik \& Turid Aarseth

Kapittel 6 Prosessorienterte modeller - tre organisatoriske utfordringer 145 Mona Jerndahl Fineide

Kapittel 7 Digitalisering - løsninger og problemer 169 Catharina Bjørkquist

Kapittel 8 Bedre tverrfaglig innsats - styrket tverrsektorielt samarbeid om utsatte barn og unge? 193 Marit K. Helgesen 


\section{Introduksjon: Behovet for samordning og samarbeid}

\section{Catharina Bjørkquist}

Avdeling for helse og velferd, Høgskolen i Østfold

Mona Jerndahl Fineide

Avdeling for helse og velferd, Høgskolen i Østfold

\section{Samordning i et organisasjonsperspektiv}

Det er krevende å få til et helhetlig og samordnet tjenestetilbud til brukere med komplekse og sammensatte behov. Utfordringene er beskrevet $\mathrm{i}$ flere studier og offentlige utredninger de siste tiårene. ${ }^{1}$ Når brukerne opplever tjenestene som fragmenterte og lite sammenhengende, kan det være et uttrykk for sviktende samordning. Dette kan blant annet resultere i unødvendige sykehusinnleggelser og reinnleggelser, komplikasjoner som kunne vært unngått, eller redusert funksjonsnivå for bruker. Samordning og samarbeid er ikke goder i seg selv, men det må være noe ved tjenestene og brukergruppen som gjør at man har behov for dette.

Boken har et organisasjonsperspektiv på samordning og samarbeid. Det er mange eksempler på at manglende samarbeid og samordning mellom de ulike organisasjonene og virksomhetene er en av de største utfordringene i helse- og velferdssektoren. Brukerne som har behov for flere tjenester, enten samtidig eller suksessivt, kan oppleve at tjenestene er dårlig koordinert. Over tid har mange ulike løsninger blitt lansert, og mange grep er tatt

1 Se for eksempel Helse- og omsorgsdepartementet, 2008; 2012; 2014; NOU 1986:4; NOU 2004:18; NOU 2005:3; NOU 2011:11; Sosial- og helsedepartementet, 1996.

Sitering av dette kapitlet: Bjørkquist, C., \& Jerndahl Fineide, M. (2019). Introduksjon: Behovet for samordning og samarbeid. I C. Bjørkquist \& M. Jerndahl Fineide (Red.), Organisasjonsperspektiv på samordning av helse- og velferdstjenester (s. 7-17). Oslo: Cappelen Damm Akademisk. https://doi.org/10.23865/noasp.66.cho.

Lisens: CC BY 4.0 
for å skape helhet og sammenheng i tjenestene. Forfatterne av denne boken diskuterer ulike forutsetninger for og erfaringer med løsninger og tiltak som har til hensikt å bidra til samordning og mer helhetlige tjenester. Her problematiseres kun et utvalg - som illustrasjoner på hvordan løsninger og tiltak kan analyseres og forstås i ulike kontekster og situasjoner.

Det er en rekke hindringer for samordning som må bygges ned. Overordnede strukturelle hindringer viser til eksisterende lovregulering, regler og retningslinjer. Videre skaper det utfordringer at tjenestene må være organisert på ulike måter, inkludert strukturer som må legge til rette for involvering av brukere og pårørende i ulike deler av prosessen, enten det gjelder kartlegging, beslutninger og/eller levering av tjenestene. Profesjonelle og kulturelle barrierer bunner gjerne i ulike vurderinger, holdninger og tilnærminger. Teamorganisering, samlokalisering og partnerskap er eksempler på tiltak som er rettet mot å dempe eller bryte ned organisatoriske og profesjonelle grenser i tjenestetilbudet (Abbott, 1988; Andersson, Ahgren, Axelsson, Eriksson \& Axelsson, 2011; Nylehn \& Støkken, 2002). Sviktende lederskap og uklart mandat innebærer hindringer (Bjørkquist, Forss \& Samuelsen, 2018). Relasjonelle hindringer viser til manglende tillit, personlige motsetninger og revirtenkning. Tilsvarende vil gjensidig respekt og tillit bidra til å bygge ned barrierer (Michelle \& Alma, 2014; San Martín-Rodríguez, Beaulieu, D’Amour \& Ferrada-Videla, 2005).

Et organisasjonsperspektiv innebærer at man søker etter mønstre og forklaringer i formelle strukturer og prosesser samt i uformelle strukturer og organisasjonskulturen. Dermed rettes oppmerksomheten mot styringsformer, ledelse, organisasjonsformer, organisasjonskultur, ressurser, rutiner og systemer. Bakgrunnen er en antakelse om hvordan den formelle samordningen utformes, har betydning for hvordan ansatte handler, og dermed også for tjenestene brukerne mottar. Hvorvidt faktisk atferd følger formelle regler og strukturer, er et empirisk spørsmål. Derfor er det også sentralt å forstå og forklare hvordan organisasjonskultur samt uformelle normer og regler virker inn på hvordan ledere og ansatte tenker, og på hva de gjør. Når man skal drive forbedringsarbeid i og av praksis, er det viktig å kunne forstå og forklare likheter og forskjeller mellom organisasjoner og mellom resultatene de oppnår. 
Samordning og samarbeid benyttes her som grep for å fremme helhetlige tjenester. Samordning kan ikke oppnås i et gitt tilfelle, men er en pågående prosess som stadig må (re-)etableres og vedlikeholdes. Ulike deler blir sett i sammenheng, prioritert og tilpasset hverandre, og flere aktører samarbeider gjerne på ulike måter. Brukerens behov for tjenester går ofte på tvers av organisasjonenes etablerte grenser, og mange har behov for flere tjenester samtidig og over lengre tid. Samordning skjer mellom ulike nivåer, noe som innebærer at grenser overskrides. Det kan være interdisiplinære grenser hvor koordinering skjer på tvers av ulike virksomheter og kunnskapsområder. Videre skjer samordning gjerne på tvers av profesjons- og yrkesgrenser. Interorganisatorisk samordning viser til samordning mellom organisasjoner og myndigheter, mens intereller tverrsektoriell samordning skjer på tvers av ulike samfunnssektorer. Det kan være motsetninger mellom ulike faglige og organisatoriske kulturer, verdier og praksis. Disse motsetningene kan skape utfordringer når det gjelder å tilby samordnede tjenester som svar på komplekse og sammensatte omsorgsbehov hos brukerne.

Samarbeid viser til situasjoner der koordinering skjer med utgangspunkt i frivillig innsats (Axelsson \& Axelsson 2014; Jacobsen 1993). Hvem som deltar i samarbeidet, avhenger av behovet til bruker og hvilke tjenester som skal involveres. Samarbeid kan også være formalisert i ulik grad, som for eksempel ansvarsgruppemøter eller kontraktsbaserte partnerskap. Videre er samarbeid et vesentlig kjennetegn ved det å jobbe sammen heller enn å jobbe parallelt, innenfor rammen av felles mål som fortrinnsvis også inkluderer brukere og pårørendes målsettinger (Chesters, Thistlethwaite, Reeves \& Kitto, 2011).

Det er en generell utfordring at tjenestene ikke i tilstrekkelig grad kjenner til hverandres arbeidsområder, og/eller at de har feil eller urealistiske forventinger til hva andre tjenester skal og kan bidra med. Uenighet om målene med tiltak man gjennomfører, er også en utfordring, og det samme er manglende tilbakemelding. Manglende prioritering av samarbeid fra ledelsens side er også en hindring. Dette er faktorer som gjør det vanskelig for tjenestene å få til en samordning.

Etter hvert som folk lever lenger, øker også andelen brukere med komplekse og sammensatte behov (Helse- og omsorgsdepartementet, 2012; 
2014). Helse- og omsorgstjenestene må kunne håndtere en økende andel brukere med kroniske lidelser med bakgrunn i for eksempel kols, diabetes, psykiske lidelser og demens (Helse- og omsorgsdepartementet, 2014).

\section{Helhetlige tjenestetilbud}

Samordning mellom helse- og omsorgstjenestene blir aktuelt når man skal skape et helhetlig helsetilbud til både eldre og yngre brukere med komplekse behov. Brukere med rus og psykiske lidelser vil ha behov for tjenester på tvers av spesialist- og kommunetjenesten og på tvers av ulike kommunale tjenester. Når flere i arbeidsfør alder skal være i jobb med helseproblemer, aktualiserer det samordnings- og samarbeidsbehov mellom helsetjenestene og arbeids- og velferdsforvaltningen. Utsatte barn og unge vil også ha behov for støtte fra ulike tjenester - på tvers av ulike sektorer. Arbeidsrettet bistand er ikke alltid tilstrekkelig for å komme i arbeid. Noen tjenestemottakere vil også ha behov for bistand til andre sider av livet. Det betyr at de mottar flere ulike tjenester samtidig og/eller over tid, for eksempel knyttet til bolig, gjeld, sosialhjelp, barneomsorg, rusbehandling samt helse og omsorg.

Mange av reformene har hatt til hensikt å møte den økende graden av spesialiserte og fragmenterte helse- og velferdstjenester. Når det er behov for helhetlige tjenester, vil dette kreve koordinering mellom enhetene. Her oppstår det fort samordnings- og samarbeidsproblemer. Disse kan knyttes til arbeids- og oppgavefordeling, hvor det kan oppstå dobbeltarbeid og gråsoner når det er uklart hvem som har myndighet og ansvar for hva. Ulik eller lite entydig faglig forstålse legger for det første grunnlag for ulik oppfatning av hva som er det beste tiltaket. Videre blir det ikke entydig hvor ansvaret ligger. I stedet for samtidig innsats oppstår ofte parallell - og adskilt - innsats og/eller sekvensiell innsats hvor overgangene mellom tiltak og tjenester kan innebære store utfordringer for brukerne. Med parallelle tjenestetilbud menes det at en bruker mottar tjenester fra flere virksomheter samtidig, uten at disse blir sett i sammenheng. Sekvensielle tjenestetilbud viser til at brukerne mottar én tjeneste av gangen. Hva som er det beste for bruker, er avhengig av hvilke behov, målsettinger og tjenester vedkommende har. Mennesker med sammensatte og komplekse 
problemer vil i stor grad ha behov for samtidig innsats fra ulike tjenester, ofte både fra spesialisttjenestene og kommunale tjenester. Det vil igjen kreve felles og overlappende ansvar.

\section{Samhandlingsreformen}

Brukernes og de pårørendes stemmer er en viktig del av det å skape helhetlige tjenester. Samhandlingsreformen - Rett behandling - på rett sted - til rett tid (Helse- og omsorgsdepartementet, 2008) - trekker fram at samhandlingen mellom tjenester fra sykehus og kommune, innen kommunen, mellom kommuner, mellom sykehusavdelinger og mellom personellgrupper ikke oppleves som god nok. Det er mange eksempler på at pasienter verken får tilfredsstillende oppfølging eller god nok tilgang til helsetjenester på grunn av manglende samhandling mellom ulike tjenester. Dette var en omfattende reform som hadde til hensikt å redusere presset på helsetjenesten gjennom satsing på helsefremmende og forebyggende tiltak. Hensikten var å dempe veksten i bruk av sykehustjenester. Det mente man kunne gjøres ved å overføre en større del av ansvaret for brukeren til kommunehelsetjenesten samt ved å sikre helhetlige og koordinerte tjenester til pasienter og brukere med komplekse og sammensatte behov.

Fire år etter samhandlingsreformens iverksettelse, med tilhørende endrede lovkrav, gjennomførte Riksrevisjonen en undersøkelse om ressursutnyttelse og kvalitet i helsetjenesten. Rapporten, som ble lagt frem for Stortinget i 2016, viser at det fortsatt er samordningsproblemer. Samarbeidet om pasienter med behov for tjenester fra både primær- og spesialisthelsetjenesten er ikke godt nok. Innenfor rus- og psykiatriområdet er ikke tilbudet $\mathrm{i}$ kommunene styrket i takt med nedbyggingen av døgnplasser i spesialisthelsetjenesten. Kommunene har i liten grad økt sin kapasitet og kompetanse etter innføringen av reformen (Riksrevisjonen, 2016). Det kan være flere momenter som kan forklare resultatene i undersøkelsen, og i et juridisk perspektiv viste en analyse av den rettslige reguleringen mot de sentrale politiske målene at rettsliggjøringen ikke går langt nok dersom en vil garantere at enkeltpersoner får individuelt tilpassede tjenestetilbud (Kjellevold, 2012, s. 24). 


\section{Juridiske aspekter ved samordning}

De siste årene er det foretatt en rekke rettslige reguleringer på helse- og velferdsområdet med henblikk på å sikre samordnede tjenester. Vi vil beskrive noen av de viktigste lovendringene, og refererer til anbefalt litteratur for fordypning.

I kjølvannet av samhandlingsreformen ble lov om kommunale helseog omsorgstjenester vedtatt i 2011. Denne var gjeldende fra 2012. Kommunene styres forholdsvis stramt gjennom den nye loven for å sikre helhetlige og koordinerte tjenestetilbud, og her har hensynet til målet om helhet og samordning fått veie tyngre enn hensynet til kommunalt selvstyre (Kjellevold, 2012, s. 8). Rettigheter for pasienter og brukere er nært knyttet til plikter for de virksomhetene som gir helse- og omsorgstjenester. Når det gjelder helseretten som rettsområde og reguleringer inn mot krav om samordning, viser vi til Befring, Hirst, Ohnstad \& Paulsrud, (2019). Lov om folkehelsearbeid ble vedtatt i $2011 \mathrm{og}$ var gjeldende fra 2012. Samtidig ble det vedtatt endringer i en rekke andre lover for å lovfeste kravet til samordning.

For å bidra til helhetlige og koordinerte tjenester er det ofte nødvendig at profesjonsutøvere utveksler informasjon. Dette krever kunnskap om de rettslige rammene rundt informasjonsutvekslingen samt om muligheter og begrensninger i kommunikasjonsadgangen (Ohnstad, 2011, s. 91). Her er det verdt å merke seg at helsepersonellovens $₫ 33$ pålegger helsearbeidere en rettslig plikt til å gi opplysninger til barnevernet når det er grunn til å tro at et barn blir utsatt for omsorgssvikt. Dette er en plikt som hviler på den enkelte helsearbeider, men overholdelse av den må sees i sammenheng med at det er utviklet gode rutiner og systemer på arbeidsplassen. Når det gjelder taushetsplikt, samtykke og opplysningsplikt, viser vi til Ohnstad (2011) og Kjønstad (2014).

\section{Forskningsbidragene i boken}

Boken skal bidra til ny kunnskap og være til nytte for praksisfeltet. Overordnet sett diskuteres spørsmålene knyttet til ulike løsninger og virkemidler for samordning som kan være egnet i ulike situasjoner og kontekster, og hvilke utfordringer som oppstår. 
Samordning og samarbeid innenfor helse- og velferdstjenestene er et bredt og mangfoldig felt, og vi har ikke gjort noe forsøk på begrense forfatternes tilnærminger ut over at det skal handle om ulike organisatoriske løsninger og tiltak som har til hensikt å bidra til samordning og skape mer helhetlige tjenester. Vi har ønsket kritiske tilnærminger og perspektiver på hvordan disse ulike organisatoriske løsningene virker som barrierer eller drivere for samordning. Kapitlene illustrerer mangfoldet i forskningen om utforming og tilrettelegging for helhetlige tjenester på tvers av sektorer, faglige enheter og nivåer. Boken åpner med et kapittel om ulike forskningstilnærminger til samordning og samarbeid som viser mangfoldet i perspektiver og fagtradisjoner. De etterfølgende bidragene kan alle plasseres innenfor disse tilnærmingene, og kapitlet rammer slik sett inn bokens organisasjonsperspektiv på samordning og samarbeid.

I kapittel to redegjør Tone Alm Andreassen for tre ulike tilnærminger i forskningen om samordning og samarbeid, henholdsvis forskningen om integrerte tjenester, om nettverksstyring og om interorganisatorisk samarbeid og organisatoriske nettverk. De tre tilnærmingene har sine viktigste forankringer $\mathrm{i}$ henholdsvis helsetjenesteforskningen, forvaltningsforskningen og organisasjonsforskningen. De retter oppmerksomheten mot ulike typer organisasjoner og motivasjon for samordning og samhandling på tvers, og de kan derfor utfylle hverandre i analyser av samordning og samarbeid i helse- og velferdstjenestene.

I kapittel tre vil Gunnar Vold Hansen vise at reell brukermedvirkning avhenger av at beslutningsprosessen er organisert slik at brukeren faktisk får innflytelse på de beslutningene som fattes. Helhetlige og samordnede tjenester innebærer at brukeren er med på å planlegge tjenestetilbudet sammen med de som skal yte tjenestene. Bruker skal være en sentral aktør i planleggingen, utformingen og tildelingen av tjenestene han eller hun mottar. Dette knyttes an til delt beslutningstaking, som krever informasjonsdeling og at bruker har reelle valgmuligheter.

Mia Vabø ser i kapittel fire nærmere på tverrprofesjonelt samarbeid i ulike styringskontekster. Med eksempler hentet fra hverdagsrehabilitering (HVR) i to kommuner viser hun hvordan en likelydende idé ble fortolket i lys av kommunenes ulike styringsambisjoner, og hvordan 
omfanget og formen for samarbeid ble preget av ulikheter i forvaltningsstruktur, tildelingspraksis og tiltro til faglig skjønn. Med henvisning til disse ulikhetene argumenterer hun for at det på ingen måte er entydig og gitt hva et tverrprofesjonelt samarbeid er.

Med tittelen «Tverrfaglige team - hvordan lykkes»? gjennomgår Helge Ramsdal i kapittel fem noen perspektiver på teamorganisering i helse- og velferdssektoren. Spørsmålet er hvordan team kan bli effektive med tanke på sine mål og oppgaver. Kapittelet viser betydningen av å foreta en kritisk vurdering av den sammenhengen etablering av nye team inngår i, og at en er bevisst på utfordringer som vil kunne møte teamene, avhengig av hvilke organisatoriske løsninger en velger.

I kapittel seks presenterer Erlend Vik og Turid Aarseth en studie av koordinatorordningen som virkemiddel for samordning i helsetjenesten. Forfatterne peker på at ordningen er rettet mot å håndtere profesjonelle og organisatoriske grenser i helsetjenesten fremfor å bryte dem ned. Dette er en ordning som viderefører og kan forsterke en oppdeling hvor ulike systemer har sine egne forstålser og kulturer. Flere koordinatorordninger overlapper hverandre og griper inn i hverandres ansvars- og funksjonsområder. Det oppstår ytterligere spesialisering og nye grensedragninger mellom delsystemene.

Mona Jerndahl Fineide diskuterer i kapittel syv hvilke organisatoriske utfordringer som bør håndteres for at prosessorienterte modeller kan bidra til bedre samordning. Behandlingslinjer er et illustrerende eksempel på en slik prosessorientert tilnærming, og det empiriske materialet er hentet fra en studie om innføring av to ulike behandlingslinjer for ADHD. Hun trekker frem at anvendelsesområdet for behandlingslinjen er viktig å vurdere, at det anvendes hensiktsmessig verktøy og teknikker, $o g$ at det forberedes for god implementering.

I kapittel åtte diskuterer Catharina Bjørkquist muligheter og utfordringer for samordning når helse- og velferdstjenester digitaliseres. Den offentlige politikken begrunner digitalisering ut fra krav om effektivisering og frigjøring av ressurser. Digitale fagsystemer kan hindre kommunikasjon og informasjonsflyt, for eksempel ved at informasjon ikke oppdateres eller at ansatte mangler tilgang. IKT-systemer skaper mindre profesjonelt handlingsrom. Tjenesteytere finner ulike metoder for å gjøre 
motstand mot de digitale systemene. Dette skaper utfordringer med å samordne tjenester.

I kapittel ni studerer Marit Helgesen det digitale verktøyet Bedre Tverrfaglig Innsats (BTI). Verktøyet skal sikre tidlig innsats til utsatte barn og unge, og det skal fremme samarbeid mellom kommunale tjenester og tjenesteytere. Det blir færre tverrfaglige møteplasser, og de ansatte mister fora hvor tjenesteytere kan utvikle felles holdninger og verdier. Deler av verktøyet blir ikke oppdatert, noe som fører til manglende transparens. Slik BTI er implementert og fungerer i dag, er det en rekke utfordringer med hensyn til å bryte ned grenser og sikre samordning og samarbeid.

\section{Referanser}

Abbott, A. (1988). The system of professions. Chicago: University of Chicago Press.

Andersson, J., Ahgren, B., Axelsson, S.B., Eriksson, A. \& Axelsson, R. (2011).

Organizational approaches to collaboration in vocational rehabilitation - an

international literature review. International Journal of Integrated Care, 11(4), 1-10. https://doi.org/s10.5334/ijic.670

Axelsson, R. \& Axelsson, S.B. (2014). Organisering av samverkan - modeler svårigheter och möjligheter. I E. Willumsen \& A. Ødegård (Red.), Tverrprofesjonelt samarbeid - et samfunnsoppdrag, s. 205-218. Oslo:

Universitetsforlaget.

Befring, A., Hirst, M., Ohnstad, B. \& Paulsrud, K. (2019). Helserett $i$ et nøtteskall (Nøtteskallserien). Oslo: Gyldendal.

Bjørkquist, C., Forss, M. \& Samuelsen, F. (2018). Collaborative challenges in the use of telecare. Scandinavian Journal of Caring Sciences. https://doi.org/10.1111/scs.12605

Chesters, J., Thistlethwaite, J., Reeves, S. \& Kitto, S. (2011). Introduction: A Sociology of Interprofessional Healthcare. I S. Kitto, J. Chesters, J. Thistlethwaite \& S.

Reeves (Red.), Sociology of interprofessional health care practice. Critical reflections and concrete solutions (s. 1-8). New York: Nova Science Publishers, Inc.

Goodwin, N. (2016). Understanding and evaluating the implementation of integrated care: A 'three pipe' problem. International Journal of Integrated Care, 16(4), 19. https://doi.org/10.5334/ijic.2609

Helse- og omsorgsdepartementet (2014). Fremtidens primoerhelsetjeneste - noerhet og helhet (Meld. St. nr. 26 (2014-2015)). Oslo: Helse- og omsorgsdepartementet.

Helse- og omsorgsdepartementet. (2012). Morgendagens omsorg (Meld. St. nr. 29 (2012-2013)). Oslo: Helse- og omsorgsdepartementet. 
Helse- og omsorgsdepartementet. (2008). Samhandlingsreformen. Rett behandling - på rett sted - til rett tid (St.meld. nr. 47 (2008-2009)). Oslo: Helse- og omsorgsdepartementet.

Jacobsen, D.I. (1993). Hvorfor er samarbeid så vanskelig? I P. Repstad (Red.), Dugnadsånd og forsvarsverker: tverretatlig samarbeid i teori og praksis (s. 75-114). Oslo: Universitetsforlaget.

Kaehne, A. (2016). The building blocks of integrated care. International Journal of Integrated Care, 16(4), 5. https://doi.org/10.5334/ijic.2527

Kjellevold, A. (2012). Ny lov om kommunale helse- og omsorgstjenester: verdivalg og rettslig regulering. Tidsskrift for erstatningsrett, 9(1-2), s. 15-44.

Kjellevold, A., Søvig, K.H. \& Østenstad, B.H. (2016). Helse- og omsorgstjenesteloven : Med kommentarer (Fagbokforlagets lovkommentarer). Bergen: Fagbokforlaget.

Kjønstad, A. (2014). Taushetsplikt om barn: Kommunikasjon og samarbeid mellom helse- og omsorgstjenesten, skoleetaten, sosialtjenesten i NAV og barnevernstjenesten (4. utg.). Oslo: Kommuneforlaget.

Michelle, J. \& Alma, H. (2014). Principals leading successful organisational change: Building social capital through disciplined professional collaboration. Journal of Organizational Change Management, 27(3), 473-485. https://doi.org/10.1108/ JOCM-07-2013-0116

Miller, R. (2016). Crossing the cultural and value divide between health and social care. International Journal of Integrated Care, 16(4). https://doi.org/10.5334/ijic.2534

NOU 1986:4 (1986). Samordning i helse- og sosialtjenesten. Oslo: Forbruker- og administrasjonsdepartementet.

NOU 2004:18 (2004). Helhet og plan i sosial-og helsetjenestene. Samordning og samhandling i kommunale sosial- og helsetjenester. Oslo: Helse- og omsorgsdepartementet og Arbeids- og sosialdepartementet.

NOU 2005:3 (2005). Fra stykkevis til helt - En sammenhengende helsetjeneste. Oslo: Helse- og omsorgsdepartementet.

NOU 2011:11 (2011). Innovasjon i omsorg. Oslo: Helse- og omsorgsdepartementet.

NOU 2017:12 (2017). Svikt og svik - Gjennomgang av saker hvor barn har vert utsatt for vold, seksuelle overgrep og omsorgssvikt. Oslo: Barne- og likestillingsdepartementet.

Nylehn, B. \& Støkken, A.M. (2002). De profesjonelle: relasjoner, identitet og utdanning. Oslo: Universitetsforlaget.

Ohnstad, B. (2011). Velferd, rettssikkerhet og personvern. Bergen: Fagbokforlaget.

Riksrevisjonen. (2016). Riksrevisjonens undersøkelse av ressursutnyttelse og kvalitet $i$ helsetjenesten etter innføringen av samhandlingsreformen Dokument 3:5 (20152016). Til Stortinget.

San Martín-Rodríguez, L., Beaulieu, M.-D., D’Amour, D. \& Ferrada-Videla, M. (2005). The determinants of successful collaboration: A review of theoretical and 
empirical studies. Journal of Interprofessional Care, 19(sup1), 132-147. https://doi. org/10.1080/13561820500082677

Sosial- og helsedepartementet. (1996). Åpenhet og helhet - Om psykiske lidelser og tjenestetilbudene (St. Meld. nr. 25 (1996-1997)). Oslo: Sosial- og helsedepartementet. 



\title{
KAPITTEL 1
}

\section{Tilnærminger i forskning om samordning og samarbeid}

\author{
Tone Alm Andreassen ${ }^{1}$ \\ Senter for profesjonsstudier, OsloMet - storbyuniversitetet
}

\begin{abstract}
Sammendrag: Dette kapitlet presenterer tre forskningstilnærminger til samordning ogsamhandling-henholdsvisforskningenomintegrertetjenester,omnettverksstyring og om interorganisatorisk samarbeid og organisatoriske nettverk. Disse tilnærmingene har sine viktigste forankringer i henholdsvis helsetjenesteforskningen, forvaltningsforskningen og organisasjonsforskningen. Framstillingen legger hovedvekten på hva forskningstilnærmingene har vært opptatt av, ikke hva forskningen forteller om hvorvidt samordning og samarbeid fungerer og leder til ønskede resultater. Kapitlet bygger primært på litteratur som søker å sammenfatte og systematisere de ulike tilnærmingene.

Hensikten er å vise at en i forskningen kan nærme seg spørsmål om samordning og samarbeid på tvers av fag, profesjoner, organisasjoner og sektorer med ulike forskningsinteresser, begreper og teoretiske perspektiver. Denne variasjonen representerer en ressurs i empiriske studier. De tre tilnærmingene retter oppmerksomheten mot ulike typer organisasjoner samt motivasjon for samordning og samhandling på tvers. De kan derfor kan utfylle hverandre i analyser av samordning og samarbeid i helse- og velferdstjenestenes organisasjoner.
\end{abstract}

Nøkkelord: samordning, samhandling, interorganisatorisk samarbeid, nettverk, nettverksstyring, forskningstilnærminger

\section{Introduksjon}

Spørsmål om samordning og samhandling på tvers av organisatoriske og faglige grenser diskuteres og analyseres innenfor flere vitenskapelige tradisjoner med ulike begrepsapparat og interesseområder. Innenfor

1 Kapitlet er utviklet i forbindelse med oppbyggingen av kjerneforskningsmiljøet INTEGRATE, med støtte fra Norges forskningsråd, prosjekt nr. 269298.

Sitering av dette kapitlet: Alm Andreassen, T. (2019). Tilnærminger i forskning om samordning og samarbeid. I C. Bjørkquist \& M. Jerndahl Fineide (Red.), Organisasjonsperspektiv på samordning av helse- og velferdstjenester (s. 19-46). Oslo: Cappelen Damm Akademisk. https://doi.org/10.23865/noasp.66.ch1.

Lisens: CC BY 4.0 
forvaltningsforskningen, det som på engelsk betegnes som public administration eller public management, finnes en forskningstilnærming knyttet til begrepet governance - som jeg her omtaler som «nettverksstyring». Innenfor organisasjonsforskningen finnes det analyser som tar for seg interorganisatorisk samarbeid og organisatoriske nettverk. Innenfor helsetjenesteforskningen har det den senere tid vokst fram en tilnærming som er opptatt av integrerte tjenester.

Med forskningstilnœrminger refererer jeg ikke til klart definerte fag eller disipliner, men til måter å analysere og forstå et samfunnsfenomen på. Det er også et poeng at tilnærmingene deles av flere og brukes over tid, slik at de kan representere felles perspektiver eller pågående diskusjoner, og eventuelt beskrives som forskningstradisjoner. Mange samfunnsspørsmål behandles innenfor flere ulike forskningstradisjoner eller -tilnærminger med ulike begrepsapparat og perspektiver. Greenhalgh og medforfattere har for eksempel identifisert 13 ulike tilnærminger i forskningen om spredning av innovasjoner (Greenhalgh mfl., 2005). Slik er det også med forskning om interorganisatorisk samarbeid (Cropper, Ebers, Huxham \& Ring, 2011, 2012).

Motivasjonen for dette kapitlet har vært at jeg gjennom flere tiår, innenfor forskning om problemstillinger som krysser faglige og organisatoriske grenser, har erfart at slike problemstillinger blir behandlet i mange ulike faglige sammenhenger. Ønsket mitt er å vise fram noen sentrale tilnærminger som kan tilby viktige analytiske perspektiver i forskning om samordning og samarbeid. Hensikten er å bidra til mer klarhet om forskjeller og likheter mellom ulike tilnærminger når det gjelder hvordan forskningen nærmer seg temaet, hvilke problemstillinger man er opptatt av, hvilke typer organisasjoner som får oppmerksomhet, og hvordan organisasjonene forstås. Derfor er jeg ikke først og fremst opptatt av hva forskningen har funnet ut, men snarere av hva disse tilnærmingene oppfatter som interessant å forske på.

Selv om jeg beskriver det som tre ulike tilnærminger, er det ikke slik at de er fullstendig adskilte. Forfattere kan publisere og trekkes på innenfor flere av tilnærmingene. Dette gjelder for eksempel den praksisnære forskningen til Huxham og medforfattere om hva som skal til for at interorganisatorisk samarbeid kan fungere (Huxham, 2000, 2003), og som jeg her først og fremst presenterer under forskningen om interorganisatorisk 
samarbeid. Videre rommer The Oxford Handbook of Inter-Organizational Relations (Cropper mfl., 2012) bidrag både fra forvaltningsforskningen og fra organisasjonsforskningen. I sin gjennomgang av sju teoretiske rammeverk for tverrsektorelt samarbeid, viser Bryson og medforfattere at de fleste trekker på flere typer teorigrunnlag, inkludert organisasjonsteori, forvaltningsteori og ledelsesteori (Bryson, Crosby \& Stone, 2015).

Et sentralt fellestrekk er at tilnærmingene retter oppmerksomheten mot samhandling og samordning som har nettverkskarakter. Dette er former for samhandling som bygger på sosiale forpliktelser, ikke juridisk definerte plikter, markedets kontraktsbaserte transaksjoner eller hierarkiets ovenfra-og-ned-styring (Powell, 1990; Thompson, 1991).

De forskningstilnærmingene jeg tar fram, er omfattende, og i denne korte presentasjonen blir det ikke plass til mange nyanser. Hovedkildene mine er oversiktsartikler og oppsummeringer, og jeg bruker litteratur jeg har samlet opp gjennom mange år. Grunnen til at en publikasjon har fanget min interesse, er, slik det ofte er i vitenskapelig arbeid, at den har blitt referert til av andre. Når jeg har identifisert nyttige kilder, har jeg benyttet snøballmetoden og sett på hvem som har sitert denne kilden (slik det framkommer av Google Scholar) for å finne flere og nyere bidrag. Mye relevant litteratur (som mine kilder trekker på) framkommer dermed ikke av litteraturlisten til dette kapitlet. Den finnes derimot om man går til kildene - i referanselistene til de publikasjonene jeg nevner her. For å gjøre videre litteratursøk enklere refererer jeg sentrale engelske termer.

Presentasjonen starter med den tilnærmingen som ligger nærmest helse- og velferdstjenestene, nemlig forskningen om integrerte tjenester. Deretter presenterer jeg nettverksstyrings-tilnærmingen, og så forskningen om interorganisatorisk samarbeid, før jeg avslutter med å se nærmere på noen sentrale forskjeller mellom tilnærmingene.

\section{Forskning om integrerte tjenester}

Det jeg her omtaler som forskning om integrerte tjenester, er en forskningstilnærming som synes å være tett knyttet til helse- og omsorgstjenestene. På engelsk brukes ofte begrepet integrated care eller integrated services. Lignende begreper er shared care, continuing care, transmural 
care og comprehensive care (Minkman, Ahaus, Fabbricotti, Nabitz \& Huijsman, 2008) eller coordinated care og seamless care (Goodwin, Stein \& Amelung, 2017). Som begrepene indikerer, er dette en forskning som har forbindelser til helsetjenesteforskningen og oppmerksomhet på helsesektorens oppgaver og utfordringer. Forskningen har også inkludert helsetjenestenes forbindelser til andre tjenestesektorer, da først og fremst sosiale tjenester. Når det dreier seg om sosiale tjenester, for eksempel tjenester til utsatte familier, brukes også begreper som integrated services, integrated service delivery eller joint working. Her omtaler jeg det som forskning på integrerte tjenester, først og fremst fordi ordet «omsorg» på norsk gir snevrere assosiasjoner enn begrepet «care».

Begrepet integrated care peker også på forskningstilnærmingens kobling til utviklingen og utbyggingen av primærhelsetjenester (Amelung mfl., 2017; Gröne \& Garcia-Barbero, 2001; Valentijn, Schepman, Opheij \& Bruijnzeels, 2013). Det beskriver en tenkning om organisering av helsetjenester som er vokst ut av primærhelsetjenestebevegelsen, som er et svar på veksten i kroniske sykdommer og multimorbiditet, og som forstås som et paradigmatisk skifte i måten helsetjenester ledes og leveres på (Goodwin mfl., 2017)

Forskningen om integrerte tjenester er ung. Tidsskriftene Journal of Integrated Care (JICA) og International Journal of Integrated Care (IJIC) ble startet rundt årtusenskiftet, mens JournaI of Interprofessional Care ble startet i 1996. I 2002 ble dette beskrevet som et raskt voksende forskningsfelt (Kodner \& Spreeuwenberg, 2002). I 2017 blir integrated care omtalt som et dominerende tema i helsetjenesteledelse og design av helsetjenestesystemer (Amelung mfl., 2017).

I et spesialnummer av International Journal of Integrated Care om kunnskapsstatus om integrerte tjenester framhever redaktøren at forskningen er svært begrepsorientert (Kaehne, 2016). Det finnes også en empirisk forskning om integrerte tjenester, med hovedvekt på prosesser. Nedenfor presenteres disse to typene forskningsbidrag.

\section{Begreps- og modellutvikling}

Én type bidrag innenfor forskningen om integrerte tjenester dreier seg å konseptualisere innholdet og elementene i disse tjenestene. Forskerne 
søker å få grep om hvilke elementer som er vesentlige for å realisere, forbedre, utvikle og opprettholde integrerte tjenester (Minkman mfl., 2008). Det gjøres ut fra mål om å utvikle begreper og modeller som kan gi dekkende forståelser av hva disse tjenestene består av, og hvordan dette kan oppnås. Et mål er også at det kan utvikles konsensus, felles forståelse og felles bruk av begreper og modeller.

Noen bidrag består av en gjennomgang av faktorer som har betydning (Axelsson \& Axelsson, 2006; Cameron, Lart, Bostock \& Coomber, 2014), eller av strategier som kan tas i bruk (Kodner \& Spreeuwenberg, 2002), uten at disse er satt sammen i en modell. Andre bidrag tilbyr mer helhetlige modeller eller rammeverk. Et eksempel er en Development Model for Integrated Care (DMIC) (van Duijn, Zonneveld, Montero, Minkman \& Nies, 2018), som er bygget på en kvalitetsledelsesmodell for integrated care (Minkman mfl., 2008). Sentrale faktorer i denne modellen er gruppert under ni hovedoverskrifter: personsentrering, leveringssystem, resultatmåling, kvalitet, resultatfokusert læring, tverrfaglig teamarbeid, definerte roller og oppgaver, forpliktelse, og entreprenørskap. En modell over faktorer som er nødvendige for å sikre implementering av integrerte tjenester (Maruthappu, Hasan \& Zeltner, 2015), løfter fram blant annet adekvat finansiering, endring av kliniske kulturer, understøttende regulering, fleksibel reorganisering, IT-infrastruktur, ledelse og delte verdier. En «regnbuemodell» som søker å fange faktorer på mikro-, meso- og makronivå (Valentijn mfl., 2013), peker på at integrerte tjenester fordrer klinisk integrering rundt den enkelte pasient, integrering mellom profesjonene, organisatorisk integrasjon og systemintegrasjon. Det er utviklet modeller for måling og evaluering av tjenesteintegrering (Browne, Kingston, Grdisa \& Markle-Reid, 2007; Browne mfl., 2004). En modell for helhetlig evaluering av intervensjoner for å etablere integrerte tjenester, og som søker å fange både kontekst, utfall og mekanismer (COMIC Model), er bygget på komparasjon av «tykke» casestudier (Busetto, Luijkx \& Vrijhoef, 2017). Det er også utviklet modeller for å evaluere integrerte tjenester fra et brukerperspektiv (Ahgren, Axelsson \& Axelsson, 2009).

Begreps- og modellutviklingen har skjedd blant annet gjennom litteraturgjennomgang og ekspertintervjuer som anvendes til å utlede og systematisere dimensjonene eller elementene som modellene settes sammen 
av. Det synes også være en forståelse av at begrepsdefinisjoner og modeller kan valideres gjennom diskusjon med eksperter (Valentijn mfl., 2013), og gjennom uttesting av om de fungerer for å fange opp praksis (van Duijn mfl., 2018).

Begrunnelsene for modellutviklingen er at dette er nødvendig for at forskningen, policy-analysene og praksisen kan forstå og bruke forskningen til å veilede kunnskapsutvikling, evidens og læring. Det er nødvendig for å bevege dette framvoksende feltet ytterligere framover (Kodner \& Spreeuwenberg, 2002). Det er også nødvendig for å kunne sammenligne ulike initiativer for å styrke integrerte tjenester (Valentijn mfl., 2013), og for å legge til rette for systematisk kvalitetsutvikling (Minkman mfl., 2008).

\section{Kartlegging av praksis}

En annen type forskning om integrerte tjenester dreier seg om å kartlegge eller undersøke disse tjenestene empirisk. Slike bidrag består av å kartlegge empiriske typer innsats eller programmer som er prøvd ut, av å sammenligne og høste kunnskap, erfaringer og lærdommer på tvers, eller av å oppsummere på tvers av ulike studier for å trekke generelle lærdommer og utlede anbefalinger for politikkutformere og ledere (Leutz, 1999). Konseptuelle modeller kan da brukes som rammeverk som peker på forhold som bør undersøkes (Minas, 2016; Mur-Veeman, van Raak \& Paulus, 2008; van Duijn mfl., 2018).

Ett formål med slike empiriske studier har vært å kunne si noe om hvilke dimensjoner eller elementer som er sentrale for å oppnå integrerte tjenester (van Duijn mfl., 2018). Et annet formål har vært å vise fram gode eksempler å lære av (Amelung mfl., 2017). Et tredje formål har vært å sammenligne på tvers av land eller målgrupper, og belyse betydningen av institusjonell kontekst eller av type problemsituasjon (Minas, 2016; Mur-Veeman mfl., 2008). Slike analyser peker på at både nasjonal kontekst og den konkrete institusjonelle konteksten rundt problemområdet (utsatte familier, ungdom utenfor arbeid eller utdanning, arbeidslivsintegrering av marginaliserte, eldre omsorgstrengende) har betydning for hva slags modeller som utformes (Minas, 2016). Det pekes også på at en 
tydelig proaktiv politikk fra nasjonale og regionale myndigheter har betydning, men ikke er tilstrekkelig, og at land som har en lite utviklet politikk for integrerte tjenester, også har en svak førstelinje (Mur-Veeman mfl., 2008).

Det finnes også systematiske kunnskapsgjennomganger som søker å oppsummere og evaluere effektene av integrerte tjenester. Et eksempel på dette er en gjennomgang som fant at programmer rettet mot spesifikke grupper pasienter med kroniske lidelser hadde positiv effekt på kvaliteten, selv om det var stor variasjon i hva programmene inneholdt (Ouwens, Wollersheim, Hermens, Hulscher \& Grol, 2005). Pasientopplæring og støtte til egenomsorg, kombinert med strukturert klinisk oppfølging, tverrfaglige team og tverrfaglige forløp var innholdet i flere programmer.

I spesialnummeret av International Journal of Integrated Care, som omhandler den oppsamlede kunnskapen om integrerte tjenester (Kaehne, 2016), peker redaktøren på at det finnes eksempler på vellykket integrering på tvers av helsetjenester og sosiale tjenester, men at disse er enkeltstående tilfeller og ikke representerer allmenne, overførbare svar. Snarere viser de bredden av mulige løsninger, og hvorvidt løsningene er anvendt andre steder, avgjøres av lokale forhold. Noen sentrale faktorer framheves likevel: opplæring, utdanning og fagutvikling.

Redaktøren peker videre på at det er forsket lite på effekter for pasientene av integrerte tjenester, og på hvilke faktorer som predikerer vellykket integrering, men at det er gode grunner for denne situasjonen: Fordi integrerte tjenester dreier seg om mellommenneskelig samhandling, vil hva som fungerer eller ikke, være kontekstavhengig og vanskelig å gripe med konvensjonelle forskningsdesign. Selv om nye forskningsparadigmer kan ha mer å tilby, kan det likevel hende at feltet må innse at de mest lovende metodene for å bedre pasientenes situasjon vil forbli «underbekreftet» (under-evidenced), sier redaktøren (Kaehne, 2016).

\section{Samordning, ikke nødvendigvis samarbeid}

Verdt å merke seg er at forskningen om integrerte tjenester dreier seg om koordinering - eller samordning - i bred forstand, ikke bare om samhandling og samarbeid. Integrerte tjenester er resultatet av koordineringen. 
Koordinering er et virkemiddel for å oppnå integrerte tjenester, og kan skje gjennom interorganisatorisk og interprofesjonelt samarbeid, som er mekanismer som forutsetter samhandling mellom de som skal koordinere seg. Integrerte tjenester kan imidlertid også oppnås via andre mekanismer, for eksempel gjennom former for «standardisering» (Mintzberg, 1979). Et eksempel på standardisering av arbeidsprosesser kan være «pakkeforløp» for hva som skal skje ved en bestemt diagnose. Slike former for koordinering forutsetter et overordnet nivå som står for samordningen.

I litteraturen beskrives det hvordan integrerte tjenester kan oppnås gjennom (en kombinasjon av) både hierarki, marked og nettverk (Axelsson \& Axelsson, 2006; Valentijn mfl., 2013). Samtidig framheves nettverk som koordineringsform, som den ideelle kombinasjonen av fleksibilitet og opplevelse av forpliktelse (Valentijn mfl., 2013), og det understrekes at interorganisatorisk samarbeid mellom autonome organisasjoner er sentralt i helsetjenestesystemer som nettopp består av et mangfold av ulike organisasjoner (Axelsson \& Axelsson, 2006).

\section{Politikknær forskning}

Formålet med forskningen om integrerte tjenester er knyttet til utfallet av samordningen og samhandlingen på tvers av ulike tjenesteytende organisasjoner, nemlig at tjenestene leveres integrert til mennesker som har sammensatte problemer, mangesidige og langvarige relasjoner til helseog velferdstjenestene. Det beskrives som et moralsk arbeid, motivert av et engasjement for kvalitet i pasientomsorgen (Kaehne, 2018).

Det kan kanskje sies at forskningen om integrerte tjenester er praksisnær og opptatt av det som skjer i tjenestene, men på en del områder er den mer styringsnær enn praksisnær. Den handler om utviklingen av tjenestene, ikke den daglige gjennomføringen av dem. Det dreier seg om å utvikle nasjonale helsetjenestesystemer (Gröne \& Garcia-Barbero, 2001; WHO, 2015), ikke bare om å utvikle samhandling i hverdagens tjenesteyting. Typisk er kanskje at det da nystartede tidsskriftet IJIC i sitt aller første nummer har et position paper skrevet av to eksperter i det kontoret i WHO Europa som har ansvaret for å utvikle integrerte tjenester (Gröne \& Garcia-Barbero, 2001). Håndboken om integrerte tjenester er ikke 
beregnet for forskere, men for helsepolitikere og praktikere (Amelung mfl., 2017). På den måten er forskningen om integrerte tjenester koblet til politikken.

\section{Forskning om nettverksstyring}

Det jeg her beskriver som forskningen om «nettverksstyring», refererer til forskning om nettverk som styringsform - at styringen gjennom nettverk involverer og skjer i samspill mellom staten og andre aktører. På engelsk brukes uttrykket governance og i noen sammenhenger collaborative governance. Tilnærmingen plasserer seg innenfor den mer statsvitenskapelige forskningen om offentlig forvaltning. Mange sentrale tidsskrifter er veletablerte, slik som Governance, Public Administration Review, Journal of Public Administration Research and Theory og Administration \& Society, mens Public Management Review, etablert rundt år 2000, er nyere. To vitenskapelige håndbøker samt en antologi om ulike perspektiver på governance utkommer omtrent samtidig, og illustrerer begrepets voksende utbredelse, mangesidighet og kobling til ulike teoretiske perspektiver (Bevir, 2010; Levi-Faur, 2012; Osborne, 2010).

Utgangspunktet er endringer i den politiske styringen - et skifte fra government til governance (Rhodes, 1996; Sullivan \& Skelcher, 2002): Hierarkisk styring er blitt erstattet med eller utfylt av former for nettverksstyring der en rekke aktører blir involvert i den offentlige styringen og iverksettingen, og der staten eller den offentlige forvaltningen ikke lenger er den suverene autoriteten, men kun én deltaker blant flere. Her refererer altså begrepet governance til en bestemt form for styring, ikke til styring generelt, slik begrepet kan brukes i andre sammenhenger.

Mange, som Rhodes (1996), knytter nettverksstyringen til selvorganiserte interorganisatoriske nettverk og koordineringsformer karakterisert av tillit og gjensidig tilpasning, og mener nettverksstyring er noe annet enn - ikke en hybrid av - marked og hierarki. Andre inkluderer kontrakter som den sterkeste formaliseringen av nettverksstyring, mens nettverk framheves som den minst formaliserte, og partnerskap som en mellomform med mer formaliserte, felles beslutningsprosesser (Sullivan 
\& Skelcher, 2002). På norsk har begrepet samstyring blitt tatt i bruk som en oversettelse av governance (Fossestøl, 2009; Vabo \& Røiseland, 2008). Her bruker jeg nettverksstyring for å understreke at det er nettverk som er koordineringsmekanismen.

Et nettverksperspektiv på offentlig styring og forvaltning brukes også i andre sammenhenger. En litteraturgjennomgang (Lecy, Mergel \& Schmitz, 2014) peker i tillegg på forskning på nettverksorganisert tjenesteproduksjon og effekter av slik tjenesteorganisering, samt på forskning om policy-nettverk, forstått som nettverk rettet mot å prege politikkutformingen (Enroth, 2010; Smith, 1993).

\section{Beskrivelse av styringens karakter}

Mange bidrag innenfor forskningen om nettverksstyring er opptatt av å beskrive nettverksstyringens karakter og hva det er som kjennetegner nettopp den til forskjell fra andre styringsformer.

Det pekes på samfunnsendringer som bakgrunn for utviklingen av nettverksbaserte styringsformer: De problemene politiske myndigheter står overfor, er så kompliserte og involverer så mange ulike aktører at de kan ikke løses av en hierarkisk myndighet alene (Sullivan \& Skelcher, 2002). Statens styringsmyndighet er utilstrekkelig, fordi løsningene er avhengig av bidrag fra en rekke autonome aktører som ikke er direkte underlagt statens myndighet. Videre pekes det på at nettverksstyring kan sees som en reaksjon på og en motvekt til styringsutfordringer skapt av New Public Management (NPM) - nemlig koordineringsutfordringer som følge av omfattende spesialisering og oppsplitting av statlige etater $\mathrm{i}$ autonome enheter og selskaper (Christensen \& Lægreid, 2007, 2011; Klijn \& Koppenjan, 2012; Osborne, 2006; Sullivan \& Skelcher, 2002). Osborne beskriver det som framveksten av et nytt styringsparadigme, New Public Governance (Osborne, 2006).

Andre begreper blir også brukt om nye styringsformer som har etterfulgt NPM: post-NPM, joined-up government (Pollitt, 2003) eller wholeof-government (Christensen \& Lægreid, 2007). Disse begrepene dekker ikke helt det samme som nettverksstyring, for de kan også romme sterkere sentral styring og hybride kombinasjoner av nettverksstyring og 
NPM-styring. Alle begrepene viser imidlertid til forsøk på å oppnå mer samordnet og integrert offentlig styring.

Sentralt i begrepet om nettverksstyring ligger ideer om å involvere samfunnet i styringen (Peters \& Pierre, 1998). Nettverksstyringen krysser grensene mellom offentlig, privat og frivillig sektor. Det kan også dreie seg om at innbyggere og sivilsamfunnsorganisasjoner involveres i utvikling og produksjon av offentlige tjenester (co-creation, co-production) (Bovaird, 2007; Brandsen \& Pestoff, 2006), eller om at offentlige myndigheter samarbeider med private bedrifter i partnerskap (public-private partnerships) (Osborne, 2002).

Uttrykket collaborative governance peker særlig mot involvering av innbyggere, sivilsamfunn og frivillige organisasjoner. Forskningen er opptatt av nye former for demokratisk begrunnet involvering av innbyggere og brukere - og av samarbeid med sivilsamfunnets frivillige organisasjoner (Ansell \& Gash, 2008; Brandsen \& Pestoff, 2006; Emerson, Nabatchi \& Balogh, 2012). Det kan dreie seg om å bringe sammen ulike stakeholdere (eller interessenter), fra både privat, frivillig og offentlig sektor, i kollektive fora for å delta i konsensusorienterte beslutningsprosesser, det som også omtales som et samarbeid om politikkutvikling (collaborative policymaking) (Ansell, Sørensen \& Torfing, 2017). Tanken er at når politikken i større grad er informert av kunnskap om de utfordringer, interesser, ressurser og løsninger som de berørte har, vil iverksettingen fungere bedre (Ansell mfl., 2017).

At nettverksstyring kobles til demokrati, er et viktig utviklingstrekk, framhever Klijn \& Koppenjan, som tidlig satte nettverksstyring på forskningsdagsordenen (Klijn \& Koppenjan, 2012). De refererer da til det å involvere innbyggere og sivilsamfunn i den offentlige styringen, men også til et engasjement for å demokratisere nettverkene og styrke deres demokratiske legitimitet.

\section{Studier av betingelser og utfordringer}

Innenfor forskningen om nettverksstyring finnes også en rekke bidrag om hva dette innebærer i praksis. Disse studiene så på hvordan nettverk kan etableres eller mobiliseres, og på utfordringer ved nettverksstyring og i ledelse av nettverk. 
Sentrale spørsmål er blant annet hvordan interorganisatoriske samarbeidsrelasjoner kan oppmuntres og mobiliseres for politiske formål, og hva det innebærer for politiske myndigheter at politikk må implementeres gjennom autonome aktører som ikke er underlagt forvaltningens hierarkiske autoritet (O’Toole, 2003). Det pekes på at nettverk er selvorganiserte, autonome og selvstyrende, og derfor i noen grad motstandsdyktige mot overordnet styring, men også på at staten kan være en aktiv deltaker i nettverk, om enn ikke i en suveren overordnet posisjon, og styre mer indirekte og via kontroll over ressurser (Rhodes, 1996).

Videre pekes det på at nettverk kan bidra til fragmentering av ansvar (Rhodes, 1996). Når styringen involverer mange ulike aktører, er det ikke like entydig som i hierarkisk styring hvilken instans som til syvende og sist kan holdes ansvarlig (Peters \& Pierre, 1998; Sullivan \& Skelcher, 2002). Det berører derfor det som på engelsk omtales som accountability, og som av noen oversettes til ansvarsutkrevelse.

Når politikk og offentlig styring skjer gjennom komplekse samhandlingsprosesser og gjennom nettverk av autonome aktører, blir spørsmål om hvordan nettverkene organiseres, ledes og fungerer, helt sentrale (Agranoff \& McGuire, 2001; Bryson, Crosby \& Stone, 2006; Klijn, 2005; Vangen, Hayes \& Cornforth, 2015).

Et poeng er at nettverksstyring innebærer styring av kompleksitet (Huxham, 2000). Hensikten med nettverksstyring er å ivareta et offentlig formål som ikke ellers ville kunne oppnås. Interorganisatorisk samarbeid kan være den eneste veien til løsning av kompliserte sosiale problemer, og dette er samarbeidets fortrinn (collaborative advantage) (Huxham, 2003). Samarbeidets fortrinn ligger nettopp i at nettverket involverer forskjellige aktører, men forskjellene innebærer også ulike ressurser fra organisasjoner med ulike formål, ulikheter i fagterminologi, organisasjonskultur og organisatoriske prosedyrer. Dette kan danne grobunn for misforståelser, vanskeliggjøre beslutningstaking og ikke minst innebære ulikheter i makt og innflytelse (Huxham, 200o). Flere faktorer kan spille inn, så som motivasjon, ambisjoner, kapasitet og ledelse, eller mangel på alt dette (Williams \& Sullivan, 2010). En litteraturgjennomgang (Ansell \& Gash, 2008) viser at kritiske faktorer er a) hvorvidt forhistorien er preget av konflikt eller samarbeid, b) hvilke insentiver partene har til å 
samarbeide, c) ressurs- og maktbalansen mellom deltakerne, d) ledelse og institusjonelt design. Samarbeid fremmes når det etableres gode sirkler av ansikt-til-ansikt-dialog, tillitsbygging, utvikling av felles forståelse og forpliktelser, og vektlegging av resultatoppnåelse i det små (ikke bare store, langsiktige mål). Under bestemte betingelser lar samarbeidets fortrinn seg realisere (Doberstein, 2016).

Et annet poeng er at styring via nettverk stiller ledere i det offentlige overfor andre utfordringer enn styring via (internt) hierarki, og dette krever både nye ledelsesformer og nye ledelsesferdigheter (Crosby \& Bryson, 2005; Klijn, 2005; Radin, 2003; Sullivan, Williams \& Jeffares, 2012). På engelsk brukes uttrykk som network management eller governing collaboration om det vi på norsk kan omtale som nettverksledelse. Nettverksledelse dreier seg om å operere i multiorganisatoriske arrangementer (Agranoff, 2006) og å balansere mellom autonomi og gjensidig avhengighet (O'Leary \& Vij, 2012). Ledelsesoppgaver er blant annet å initiere og fasilitere samhandlingsprosesser, å etablere og omforme planer som kan sikre koordinering, å skape innhold f.eks. gjennom å utrede nye ideer og scenarioer, og å organisere felles kunnskapsoppbygging (Klijn, 2005). Det å fasilitere samarbeid er en kontinuerlig oppgave - samarbeidet må pleies (Huxham, 2003). Slik ledelse krever forhandlingsferdigheter og evne til å bygge løsninger som appellerer til dem som besitter ressurser til å implementere løsningene. Lederskap for samarbeid betyr blant annet å skape inkluderende relasjoner, jobbe i fellesskap for å identifisere løsninger, være sensitiv overfor varierende og skiftende situasjoner, og oppnå å få satt fellesskapets eller brukernes behov over organisasjonenes egne interesser (Sullivan mfl., 2012).

\section{Bestemmelse av nettverksstyringens dimensjoner}

I litteraturen finnes ulike bud på hva som er de sentrale dimensjonene i studier av nettverk. Vangen og medforfattere (2014) skiller mellom strukturer, prosesser og aktører. Klijn \& Koppenjan (2012) skiller mellom a) aktører, gjensidig avhengighet og forståelsesrammer, for å peke på at aktørene i nettverk er gjensidig avhengige, men likevel handler ut fra ulike situasjonsforståelser (rammer); b) samhandling og kompleksitet, 
som viser til komplekse samhandlings- og forhandlingsprosesser; c) institusjonelle trekk, som viser til at samhandlingsmønstre institusjonaliseres, og at regler og reguleringer kan regulere handlinger i nettverk; og d) nettverksledelse, som peker på at samhandlingen fasiliteres og gis retning (Klijn \& Koppenjan, 2012).

Emerson og medforfattere (2011) har utarbeidet et rammeverk over alle elementene i collaborative governance. Rammeverket er ment å dekke hva som er drivere for samarbeid, samarbeidsdynamikkens elementer og hva samarbeidet leder til, samt den systemkonteksten samarbeidsstyringen inngår i. Andre rammeverk eller modeller finnes også (Ansell \& Gash, 2008; Bryson mfl., 2006; Williams \& Sullivan, 2010), og Bryson og medforfattere har sammenlignet og laget en syntese av flere slike (Bryson mfl., 2015). Det er også utviklet modeller for å evaluere effekter av nettverksorganisert tjenesteproduksjon (Kenis \& Provan, 2009; Provan \& Milward, 2001).

Forskningen om nettverksstyring er knyttet til framveksten av nye politiske styringsformer fra og med 1990-tallet (Huxham, 2000). Forskningen er rettet mot å forstå, men også å bidra til å utvikle slike styringsformer. Den har ikke bare et analyserende siktemål, men også et mål om å komme til nytte, for eksempel i form av anbefalinger for ledere i offentlig sektor (Agranoff, 2006).

\section{Forskning om organisatoriske nettverk og interorganisatorisk samarbeid}

Det jeg her beskriver som forskningen om organisatoriske nettverk og interorganisatorisk samarbeid, ser ut til å være tilnærminger med litt ulikt utspring, men som møtes i studier av nettverksorganisasjoner og organisasjoners målrettede handlinger for å utnytte sitt nettverk for å fremme egne og felles interesser. Redaktørene av The Oxford Handbook of Inter-Organizational Relations viser til bidrag fra 1950-tallet som tidlige kilder til studier av interorganisatorisk samarbeid, men sier også at først fra 1970-tallet skjedde det en vekst i denne forskningen (Cropper mfl., 2012). Redaktørene peker videre på at interorganisatoriske relasjoner kan studeres gjennom en rekke teoretiske perspektiver, herunder teori om sosiale nettverk. 
Forskningen synes å ha en hovedbase i organisasjonsteori og sosiologiske tilnærminger samt i organisasjons- og ledelsestidsskrifter som Journal of Management og tidsskriftene til Academy of Management, profesjonsorganisasjonen for forskere i organisasjon og ledelse, stiftet i 1936.

Interorganisatorisk samarbeid kan forstås som kobling av situasjonsforståelse og konkrete ressurser - som informasjon, penger og arbeidskraft - for å løse problemer som den enkelte samarbeidspartner ikke kan løse alene (Gray, 1985). Grunnlaget er altså en gjensidig avhengighet mellom aktørene. At organisasjonene trenger noe fra hverandre, motiverer samarbeidet. En teoretisk inngang har vært det som omtales som resource dependence theory, om ressursavhengighet og interorganisatorisk samarbeid som tilgang til ressurser den enkelte organisasjon ikke besitter (Parmigiani \& Rivera-Santos, 2011). De samarbeidsrelasjonene aktørene inngår i, kan ta form av partnerskap, nettverk, allianser, konsortier eller joint ventures (Cropper mfl., 2012; Parmigiani \& Rivera-Santos, 2011).

\section{Studier av nettverksrelasjoner}

Studier av interorganisatoriske relasjoner fokuserer på fire hovedkomponenter: organisasjoner og trekk ved disse, relasjoner og forbindelseslinjer mellom organisasjonene, kontekst som organisasjonene er innvevd i, og prosesser som bidrar til etablering, videreføring, endring og oppløsning av relasjonene og til å produsere resultater av samarbeidet (Cropper mfl., 2012).

Begrepet nettverk opptrer også innenfor organisasjonsforskningen. Nettverk kan opptre på ulike nivåer: rundt eller mellom individer (interpersonal), for eksempel på tvers av fag eller disipliner, mellom enheter eller avdelinger innenfor en organisasjon (interunit) og mellom organisasjoner (interorganizational) (Brass, Galaskiewicz, Greve \& Tsai, 2004). I nettverksteoriens begrepsapparat kan enhver aktør (individ eller organisasjon) betraktes som en node i et nettverk som består av deres forbindelser eller bånd (ties) til andre aktører. Aktørers posisjon bestemmes både av hvor mange andre aktører de har forbindelser til (centrality), og av hvor tette disse forbindelsene er (density).

Sentrale elementer eller ideer i studier av nettverk (Kilduff \& Brass, 2010) er at dette er studier av relasjoner mellom aktører, at aktører er 
omsluttet av nettverk av relasjoner, og at aktørers posisjoner er bestemt av de nettverkene de inngår i. Videre er det sentralt at det finnes nettverksstrukturer, dvs. etablerte mønstre av bånd og fravær av forbindelser (huller) som kjennetegner et nettverk, og at nettverkene som individer, grupper og organisasjoner er innlemmet i, har konsekvenser. Et siste poeng er at nettverk kan oppstå og utvikles som en konsekvens av en rekke aktørers ikke-koordinerte handlinger og samhandlinger, eller de kan være resultat av målbevisst handling fra organisasjoner som har felles mål eller interesser (Kilduff \& Brass, 2010).

Borgatti \& Foster (2003) har identifisert ulike retninger i den organisatoriske nettverksforskningen: én retning som er opptatt av hva slags sosial støtte og hvilke ressurser individers nettverk representerer, og en annen retning som undersøker betydningen av organisasjoners nettverk for deres økonomiske transaksjoner. For eksempel kan analysene dreie seg om hvorvidt organisasjoners suksess kan forklares av deres nettverksposisjon eller trekk ved det nettverket organisasjoner inngår i. En tredje retning er opptatt av å studere nettverksorganisasjoner eller organisatoriske nettverk, altså organisatoriske former som er kjennetegnet ved samhandling mellom (delvis) autonome organisasjoner, og som bygger på tillit opparbeidet gjennom relasjoner over tid (Borgatti \& Foster, 2003).

Organisatoriske nettverk kan altså studeres som noe organisasjoner (og mennesker) er innvevd i eller omsluttet av (embedded in), eller som noe organisasjoner aktivt velger å etablere eller inngå i. Den første typen nettverksstudier retter seg mot konsekvenser av organisasjoners nettverk og nettverksposisjoner. Denne andre typen vil være studier av målorienterte nettverk, med oppmerksomheten rettet mot intenderte organisatoriske prosesser og handlende aktører, kort sagt, studier av interorganisatorisk samarbeid.

\section{Strategisk samarbeid og resultatoppnåelse gjennom nettverk}

Et sentralt tema i forskningen om interorganisatorisk samarbeid har vært hva organisasjoner kan oppnå gjennom å delta i dette. Interorganisatoriske relasjoner forstås som strategisk viktige samarbeidsrelasjoner 
mellom en organisasjon (den som studeres) og en eller flere andre organisasjoner for å dele eller utveksle ressurser i den hensikt å oppnå bedre resultater (Parmigiani \& Rivera-Santos, 2011). Forskningen undersøker hvordan interorganisatorisk samarbeid kan forbedre en organisasjons resultatoppnåelse, for eksempel gjennom spredning av risiko, deling av ressurser, utvidet fleksibilitet, økt tilgang til teknologisk kunnskap eller til nye markeder (Phillips, Lawrence \& Hardy, 2000). Gjennom samarbeid kan organisasjoner ikke bare få tilgang til økonomiske ressurser eller kunnskap, men også til legitimitet og renommé (Parmigiani \& Rivera-Santos, 2011).

Hardy og kolleger peker på tre ulike litteraturstrømninger som har vært opptatt av litt forskjellige typer resultater (Hardy, Phillips \& Lawrence, 2003). Strategilitteraturen har vektlagt at interorganisatorisk samarbeid kan legge til rette for deling av kritiske ressurser og for kunnskapsoverføring. Det de omtaler som loeringslitteraturen, framhever at interorganisatorisk samarbeid også kan bidra til kunnskapsgenerering, til utvikling av ny kunnskap og til innovasjon. Det de omtaler som en litteratur om organisasjonspolitikk, framhever at samarbeid kan endre organisasjoners posisjoner i et nettverk, og dermed også deres makt og innflytelse. Interorganisatorisk samarbeid kan derfor være noe organisasjoner tar i bruk for å styrke sin egen posisjon i et felt.

I mange tilfeller har forskningen studert resultater for den enkelte organisasjonen. Det har imidlertid også vært forsket på nettverk betraktet som subjekt - som whole networks (Provan, Fish \& Sydow, 2007), som interorganisatoriske system innenfor et domene eller felt bestående av ulike aktører som deler problemer eller interesser (Gray, 1985), eller som interorganisatoriske enheter (entities) (Cropper mfl., 2011). I denne forskningen, der nettverket eller samarbeidet er undersøkelsesenheten, flyttes oppmerksomheten fra hva den enkelte deltakende organisasjon oppnår, til hva nettverket som helhet skaper av resultater. I en litteraturgjennomgang finner Provan mfl. (2007) flest slike studier innenfor helseog sosialsektoren.

Mye oppmerksomhet har vært rettet mot organisasjoner i privat sektor og bedrifter som konkurrerer i et marked, og mot relasjonenes betydning for de økonomiske resultatene (Kilduff \& Brass, 2010). Ideelle og frivillige 
organisasjoner behandles også som aktører som forfølger sine organisasjonsinteresser og konkurrerer om givere og offentlig støtte (Hardy m.fl., 2003).

I studier av interorganisatoriske relasjoner har en forståelse av organisasjonene som rasjonelle og instrumentelle vært utbredt (Lounsbury \& Ventresca, 2003). Institusjonell organisasjonsteori gir imidlertid et blikk for at organisasjoner og de som befolker dem, er innvevd i institusjonelle logikker som de oppfatter verden gjennom og handler ut fra, og slike logikker former hva som betraktes som rasjonelt og legitimt (Lounsbury \& Ventresca, 2003). Innarbeidede logikker preger dermed også forståelsene av saken som gjøres til gjenstand for samarbeid, hvem som er rettmessige deltakere i samarbeidet, og hvordan problemene bør møtes (Phillips mfl., 200o). De kan utgjøre barrierer for samarbeid, men kan også representere ressurser deltakerne kan trekke på. Institusjonell organisasjonsteori kan dessuten rette oppmerksomheten mot hvordan institusjonelt arbeid (institutional work) kan være nødvendig for å omforme innarbeidede forståelser og praksiser, slik at samarbeid kan realiseres (Lawrence \& Suddaby, 2006; Lawrence, Suddaby \& Leca, 2009).

\section{Samarbeidsprosesser og hva som påvirker hvordan de fungerer}

Et sentralt tema, som man også har vært opptatt av i studier av nettverksstyring i offentlig sektor, har vært hvordan interorganisatorisk samarbeid fungerer, hva som påvirker hvordan samarbeidet faktisk utspiller seg, og hvordan samarbeid dermed kan tilrettelegges for.

Basert på et sett av casestudier fra både privat og offentlig sektor analyserer Gray (1985) etableringen av interorganisatorisk samarbeid gjennom tre faser: 1) etablering av en felles problemforståelse blant aktører som berøres av et problem (problem-setting), 2) utpeking av retningen for samarbeidet, av framtiden man sikter mot og verdiene aktørene enes om (direction-setting), og 3) strukturering av samhandlingen i samarbeidet (structuring). Analysen dreier seg om forhold som påvirker samarbeidet.

Gray peker på at deltakerne bør representere alle sider ved den kompleksiteten som problemet representerer. Spesielt viktig er det å få med aktører 
som kan boikotte den problemløsningen partene eventuelt kommer fram til. En utfordring kan være at det hersker uenighet om hvem som er legitime deltakere. En annen utfordring kan være at et stort antall deltakere kan gjøre prosessen mindre effektiv enn om antallet deltakere er lite, mens det å utelate berørte deltakere kan skape motstand når løsninger skal iverksettes.

For å ville delta må aktørene anerkjenne at det eksisterer en gjensidig avhengighet, og at samarbeid er nødvendig og kan virke positivt på problemløsningen. Hvis viktige aktører ikke anerkjenner dette, kan det bli nødvendig med insentiver. At samarbeid er pålagt (mandated), slik det kan være i offentlig sektor, er sjelden tilstrekkelig til å sikre at effektivt samarbeid faktisk vil finne sted.

Videre vektlegger Gray at det har betydning hvem som initierer og tar ledelsen i samarbeidet: Det kan være en aktør som allerede har legitimitet som autoritet i feltet, men hvis det er høy grad av konflikt mellom deltakerne, bør det heller være en nøytral tredjepart. Legitimitet alene er imidlertid ikke tilstrekkelig, også kompetanse er nødvendig - til å se potensialer, fremme visjoner og vise konsekvenser.

Gray argumenterer for at ressursavhengighet og nærhet mellom aktørene bidrar positivt til et samarbeid, men i alle interorganisatoriske felt vil noen grupper ha større kontroll over kritiske ressurser enn andre. Relasjonene vil være preget av makt- og avhengighetsforhold. Det kan være behov for tiltak som kan utjevne maktforhold, men på den andre siden, hvis maktbalansen blir helt jevn, er det fare for stillstand.

Hardy og Phillips (1998) peker på tre former for makt som kan utspille seg i interorganisatoriske relasjoner: Den ene er formell autoritet - at noen organisasjoner har en legitim rett til å fatte beslutninger som er vitale for samarbeidet. Den andre er ressurser - at noen organisasjoner disponerer kritiske ressurser som samarbeidet er avhengig av, for eksempel kapital eller ekspertise. Og den tredje er «diskursiv legitimitet» - at noen organisasjoner anerkjennes å ha rett til å ytre seg på vegne av en gruppe. Dette er en form for makt som gjerne besittes av interesseorganisasjoner. Interorganisatorisk samhandling vil påvirkes av samspillet mellom disse tre maktformene. Samhandlingen vil kunne utvikle seg ulikt, avhengig av hvilke mønstre av makt og avhengighet som eksisterer i et konkret felt (Hardy mfl., 2003). 
En praksisnær teori om samarbeid er utviklet av Chris Huxham, i samarbeid med Siv Vangen og andre (Huxham, 2003), i stor grad gjennom aksjonsforskning. Hensikten er å forstå hvordan samarbeidsprosesser kan forløpe - hvordan de kan tilrettelegges for, designes, ledes og understøttes - og få fram at også når samarbeidet oppfattes som vellykket, kan det ha inneholdt mange vanskeligheter (Huxham, 2003). Et poeng er at selv om samarbeidende parter må enes om felles mål, inneholder samarbeidsrelasjoner også organisasjonenes og deltakernes egne målsettinger. Ikke alle mål er eksplisitte, noen er tatt for gitt, andre er bevisst holdt skjult. Å starte med å handle kan derfor noen ganger være bedre enn å ha lange diskusjoner om mål. Et neste poeng er at maktforhold alltid er til stede, men makt ligger ikke bare hos dem deltakerne tilskriver en maktposisjon. I stedet må maktinfrastrukturen undersøkes spesifikt i den enkelte samarbeidsprosessen. Et tredje poeng er at selv om tillit ofte framheves som en forutsetning, starter samarbeid ikke sjelden med skepsis og mistenksomhet. Tillitsbygging er en nødvendig prosess, ikke et premiss. Tillitsbygging kan baseres på tidligere erfaring og deltakernes renommé, men også på at deltakerne er villige til å ta risikoen for at samarbeidet kan feile.

\section{Utfyllende tilnærminger}

Dette kapitlet har vist hvordan spørsmål om samordning og samhandling på tvers av organisatoriske og faglige grenser diskuteres og analyseres innenfor flere ulike vitenskapelige tradisjoner, med ulike begrepsapparat og ulike interesseområder, og med vekt på ulike typer organisasjoner.

\section{Samordning og offentlige organisasjoner}

I statsvitenskapen har oppmerksomheten vært rettet mot «nettverksstyring», forstått som offentlig styring som også involverer aktører fra privat og frivillig sektor. Bakteppet er en tanken om at mange samfunnsproblemer ikke kan løses av en enkelt administrasjon eller forvaltning alene, men at de krever samarbeid på tvers av sektorer og organisasjoner. 
Innenfor helsetjenesteforskningen finnes en tilnærming som er opptatt av «integrerte tjenester». Der kartlegges bestanddelene og betingelsene for å gi pasientene tilgang til slike tjenester. Integrerte tjenester til mennesker med komplekse behov er typisk en utfordring som krever samordning og samhandling på tvers av faglige og organisatoriske grenser.

Både forskningen om integrerte tjenester og forskningen om nettverksstyring virker å være sammenvevd med politikken. Særlig forskningen om integrerte tjenester synes å være utviklet som et verktøy for å operasjonalisere og implementere politikken, og som en standard å kartlegge og evaluere praksis etter. Det man ønsker å oppnå gjennom integrerte tjenester, ligner på målene for integrert offentlig styring (Kodner \& Spreeuwenberg, 2002; Pollitt, 2003; Valentijn mfl., 2013). Det dreier seg om mer helhetlige og individuelt tilpassede tjenester, om brukertilfredshet, kvalitet, bedre tilgjengelighet, fleksibilitet og kontinuitet, og om større effektivitet, mindre dobbeltarbeid og mindre sløsing med ressurser.

Begge disse to forskningstradisjonene studerer primært organisasjoner i offentlig sektor. Organisasjonene forstås som redskaper for et overordnet formål - integrerte tjenester eller god samfunnsstyring. Det overordnede formålet er et implisitt premiss i analysene - i den forstand at det er dette som berettiger forskningen. Her dreier det seg om organisasjoner som arbeider på et offentlig oppdrag, med et politisk gitt mandat.

En særegen problemstilling finnes i forskningen om organisasjoner med et politisk mandat, nemlig hvorvidt nettverksstyringen medfører fragmentert ansvar - at når mange organisasjoner er involvert i politikkutformingen og iverksettingen, blir det vanskelig se hvilke organisasjoner som skal holdes ansvarlig for det som oppnås. Et poeng er at ansvarsuklarhet kan gjøre ledere i offentlige organisasjoner mer bekvemme med hierarkisk styring og organisasjonsinterne resultatmål enn med nettverksstyring som kan gjøre det vanskelig å identifisere hver enkelt deltakers bidrag til resultatet. Dette kan forsterkes når oppgavene offentlige organisasjoner får ressurser til, er stramt avgrenset, og dersom organisasjoner og ledere blir målt på organisasjonsinterne måleindikatorer (Pollitt, 2003; Sullivan \& Skelcher, 2002; Williams \& Sullivan, 2010). For offentlige organisasjoner kan da motivasjon for samarbeid utover egen organisasjon måtte hvile på verdier om sosial rettferdighet 
og visjoner om gode tjenester til innbyggerne (Kaehne, 2018; Sullivan \& Skelcher, 2002).

Et annet trekk ved organisasjoner i offentlig sektor preger også forskningen om nettverksstyring: Gjennom sitt politiske mandat kan organisasjoner i offentlig sektor innlemmes i en overordnet plan for integrerte forløp og pålegges interorganisatorisk samarbeid. En forklaring på at de fleste studier av nettverk som subjekt finnes innenfor helse- og sosialsektoren (Provan mfl., 2007), kan være at i offentlig sektor er interorganisatorisk samarbeid i større grad stimulert eller pålagt fra overordnet nivå for å oppfylle mål utenfor det målet som er gitt den enkelte organisasjonen som deltar.

\section{Interorganisatorisk samarbeid og organisasjoner i privat sektor}

Den tredje tilnærmingen i kapitlet er en mer sosiologisk og organisasjonsteoretisk tilnærming som studerer interorganisatorisk samarbeid. Her rettes oppmerksomheten mer på organisasjoner i privat sektor. Dette dreier seg om organisasjoner som selv definerer sine mål, og som ofte opererer $\mathrm{i}$ et marked der de konkurrerer med andre. Organisasjonene forstås i stor grad som subjekter - som intensjonale, handlende aktører som velger å inngå i (eller stå utenfor) samarbeidsrelasjoner ut fra vurderinger av hva de kan oppnå gjennom deltakelsen. Samarbeidsrelasjonene er frivillige.

Det finnes også forskning om organisatoriske nettverk der organisasjonene mer opptrer som objekter, og der man studerer hvordan organisasjonenes handlingsmuligheter er bestemt av nettverkene de er innvevd i. Imidlertid rommer også nettverksforskningen studier av nettverksorganisasjoner i form av interorganisatorisk samarbeid mellom autonome organisasjoner som velger å samarbeide på tvers av organisatoriske grenser.

Forskningen om interorganisatorisk samarbeid og nettverksorganisasjoner har rettet oppmerksomheten mot hva som gjør organisasjoner motivert for å samarbeide over sine egne grenser, og hva slags resultater de oppnår gjennom samarbeidet. Motivasjonen ligger i mulighetene for 
å oppnå resultater. Et viktig poeng er at motivasjonen for interorganisatorisk samarbeid bygger på at det eksisterer en gjensidig avhengighet mellom organisasjonene. De trenger andre for å nå sine egne mål.

En illustrasjon på forskjellen mellom disse tilnærmingene er at i litteraturen om interorganisatorisk samarbeid er forskningen opptatt av hvordan den enkelte organisasjon i et samarbeid kan styrke sin posisjon og sin resultatoppnåelse, dele ressurser og spre risiko. Litteraturen om offentlig forvaltning er i én forstand opptatt av det samme, men med motsatt fortegn, nemlig av hvordan deling av ressurser og spredning av risiko innebærer fragmentering eller oppløsning av ansvar - og dermed redusert mulighet for å holde noen ansvarlig for virksomheten og resultatene.

\section{Mandat, avhengighet og motivasjon}

Innenfor alle tre tilnærmingene finnes en interesse for hvordan samarbeid kan stimuleres for å finne løsninger på utfordringer den enkelte organisasjonen ikke kan løse alene. Her kan ulikhetene mellom tilnærmingene representere utfyllende perspektiver. Forskningen om interorganisatoriske relasjoner viser hvordan samarbeid i privat sektor motiveres av gjensidig avhengighet. Til forskjell kan organisasjoner i offentlig sektor pålegges å samarbeide på tvers, for eksempel for å skape integrerte tjenester. Implementeringsforskningen har imidlertid vist at overordnede planer og mandater ikke nødvendigvis materialiseres i lokal praksis. Organisasjonstilnærmingen har bud på hvordan dette kan forstås.

Institusjonelle organisasjonsperspektiver kan peke på at rasjonelle, instrumentelle grep for å skape koordinering ikke nødvendigvis lar seg realisere hvis de bryter mot innarbeidede forståelser og praksiser. Perspektivet på organisasjonene som rasjonelle og instrumentelle viser hvordan samarbeid kan motiveres av muligheter for gevinster. I offentlig sektor kan det være slik at de som tjener på at organisasjonene samarbeider for å oppnå integrerte tjenester, er innbyggere med komplekse behov som krysser sektorgrenser. Organisasjonene, derimot, kan oppnå bedre resultatmålinger om de konsentrerer seg om oppgavene de har fått budsjett til, og resultatene de blir målt på. Samarbeid på tvers kan bli 
avhengig av lederes og fagpersoners verdier og visjoner (Kaehne, 2018). Slike organisasjonsteoretiske perspektiver kan rette oppmerksomheten mot den offentlige styringen - og mot spørsmålet om offentlige organisasjoner opplever at de er avhengige av andre for å nå sine mål, eller om de belønnes for samarbeid på tvers.

\section{Referanser}

Agranoff, R. (2006). Inside collaborative networks: Ten lessons for public managers. Public Administration Review, 66, 56-65. https://doi.org/10.1111/j.1540-6210. 2006.00666.x

Agranoff, R. \& McGuire, M. (2001). Big questions in public network management research. Journal of Public Administration Research and Theory, 11(3), 295-326.

Ahgren, B., Axelsson, S.B. \& Axelsson, R. (2009). Evaluating intersectoral collaboration: A model for assessment by service users. International journal of integrated care, 9(1).

Amelung, V., Stein, V., Goodwin, N., Balicer, R., Nolte, E. \& Suter, E. (2017). Handbook integrated care. Cham: Springer International Publishing.

Ansell, C. \& Gash, A. (2008). Collaborative governance in theory and practice. Journal of Public Administration Research and Theory, 18(4), 543-571.

Ansell, C., Sørensen, E. \& Torfing, J. (2017). Improving policy implementation through collaborative policymaking. Policy \& Politics, 45(3), 467-486.

Axelsson, R. \& Axelsson, S.B. (2006). Integration and collaboration in public health-a conceptual framework. The International Journal of Health Planning and Management, 21(1), 75-88.

Bevir, M. (2010). The SAGE handbook of governance. London: Sage.

Borgatti, S.P. \& Foster, P.C. (2003). The network paradigm in organizational research: A review and typology. Journal of Management, 29(6), 991-1013.

Bovaird, T. (2007). Beyond engagement and participation: User and community coproduction of public services. Public Administration Review, 67(5), 846-860.

Brandsen, T. \& Pestoff, V. (2006). Co-production, the third sector and the delivery of public services. Public Management Review, 8(4), 493-501. https://doi. org/10.1080/14719030601022874

Brass, D.J., Galaskiewicz, J., Greve, H.R. \& Tsai, W. (2004). Taking stock of networks and organizations: A multilevel perspective. Academy of Management Journal, $47(6), 795-817$.

Browne, G., Kingston, D., Grdisa, V. \& Markle-Reid, M. (2007). Conceptualization and measurement of integrated human service networks for evaluation. International Journal of Integrated Care, 7(4). 
Browne, G., Roberts, J., Gafni, A., Byrne, C., Kertyzia, J. \& Loney, P. (2004). Conceptualizing and validating the human services integration measure. International Journal of Integrated Care, 4(2).

Bryson, J.M., Crosby, B.C. \& Stone, M.M. (2006). The design and implementation of cross-sector collaborations: Propositions from the literature. Public Administration Review, 66(s1), 44-55.

Bryson, J.M., Crosby, B.C. \& Stone, M.M. (2015). Designing and implementing cross-sector collaborations: Needed and challenging. Public Administration Review, 75(5), 647-663.

Busetto, L., Luijkx, K. \& Vrijhoef, B. (2017). Development of the COMIC Model for the comprehensive evaluation of integrated care interventions. International Journal of Integrated Care, $17(5)$.

Cameron, A., Lart, R., Bostock, L. \& Coomber, C. (2014). Factors that promote and hinder joint and integrated working between health and social care services: a review of research literature. Health \& Social Care in the Community, 22(3), 225-233.

Christensen, T. \& Lægreid, P. (2007). The whole-of-government approach to public sector reform. Public Administration Review, 67(6), 1059-1066.

Christensen, T. \& Lægreid, P. (2011). Beyond NPM? Some Development Features. I T. Christensen \& P. Lægreid (Red.), The Ashgate research companion to new public management (s. 391-403). Aldershot: Ashgate Publishing, Ltd.

Cropper, S., Ebers, M., Huxham, C. \& Ring, P.S. (2011). Packing more punch? Developing the field of inter-organisational relations. International Journal of Strategic Business Alliances, 2(3), 153-170.

Cropper, S., Ebers, M., Huxham, C. \& Ring, P.S. (2012). The Oxford handbook of inter-organizational relations. Oxford: Oxford University Press.

Crosby, B.C. \& Bryson, J.M. (2005). A leadership framework for cross-sector collaboration. Public Management Review, 7(2), 177-201.

Doberstein, C. (2016). Designing collaborative governance decision-making in search of a 'collaborative advantage'. Public Management Review, 18(6), 819-841.

Emerson, K., Nabatchi, T. \& Balogh, S. (2012). An integrative framework for collaborative governance. Journal of Public Administration Research and Theory, 22(1), 1-29.

Enroth, H. (2010). Policy Network Theory. I M. Bevir (Red.), The SAGE handbook of governance (s. 19-35). London: Sage.

Fossestøl, K. (2009). Valgfrihet, styring eller dialog. Om samstyring av velferdsstatlig tjenesteyting. Sosiologi i dag, 39(1), 37-62.

Goodwin, N., Stein, V. \& Amelung, V. (2017). What is integrated care? I V. Amelung, V. Stein, N. Goodwin, R. Balicer, E. Nolte \& E. Suter (Red.), Handbook integrated care (s. 3-24). Cham: Springer International Publishing. 
Gray, B. (1985). Conditions facilitating interorganizational collaboration. Human Relations, 38(10), 911-936.

Greenhalgh, T., Robert, G., Macfarlane, F., Bate, P., Kyriakidou, O. \& Peacock, R. (2005). Storylines of research in diffusion of innovation: A meta-narrative approach to systematic review. Social Science \& Medicine, 61(2), 417-430.

Gröne, O. \& Garcia-Barbero, M. (2001). Integrated care. International Journal of Integrated Care, 1(2).

Hardy, C., Phillips, N. \& Lawrence, T.B. (2003). Resources, knowledge and influence: The organizational effects of interorganizational collaboration. Journal of Management Studies, 40(2), 321-347.

Huxham, C. (2000). The challenge of colloborative governance. Public Management, 2(3), 337-357.

Huxham, C. (2003). Theorizing collaboration practice. Public Management Review, $5(3), 401-423$.

Kaehne, A. (2016). The building blocks of integrated care. International Journal of Integrated Care, 16(4).

Kaehne, A. (2018). The tacit assumptions of care integration. Journal of Integrated Care, 26(4), 254-256. https://doi.org/10.1108/JICA-10-2018-057

Kenis, P. \& Provan, K.G. (2009). Towards an exogenous theory of public network performance. Public Administration, 87(3), 440-456.

Kilduff, M. \& Brass, D.J. (2010). Organizational social network research: Core ideas and key debates. The Academy of Management Annals, 4(1), 317-357.

Klijn, E.-H. (2005). Networks and inter-organizational management: Challenging, steering, evaluation, and the role of public actors in public management. I C. Pollitt, E. Ferlie \& L.E. Lynn (Red.), The Oxford handbook of public management (s. 257-281). Oxford: Oxford University Press.

Klijn, E.-H. \& Koppenjan, J. (2012). Governance network theory: Past, present and future. Policy \& Politics, 40(4), 587-606.

Kodner, D.L. \& Spreeuwenberg, C. (2002). Integrated care: Meaning, logic, applications, and implications - a discussion paper. International Journal of Integrated Care, 2(4).

Lawrence, T.B. \& Suddaby, R. (2006). Institutions and institutional work. I S.R. Clegg, C. Hardy, T.B. Lawrence \& W.R. Nord (Red.), The SAGE handbook of organization studies (Andre. utg., s. 215-254). London: Sage.

Lawrence, T.B., Suddaby, R. \& Leca, B. (2009). Institutional work: Actors and agency in institutional studies of organizations. Cambridge: Cambridge University Press.

Lecy, J.D., Mergel, I.A. \& Schmitz, H.P. (2014). Networks in public administration: Current scholarship in review. Public Management Review, 16(5), 643-665. https:// doi.org/10.1080/14719037.2012.743577 
Leutz, W.N. (1999). Five laws for integrating medical and social services: Lessons from the United States and the United Kingdom. The Milbank Quarterly, 77(1), 77-110.

Levi-Faur, D. (2012). The Oxford handbook of governance. Oxford: Oxford University Press.

Lounsbury, M. \& Ventresca, M. (2003). The new structuralism in organizational theory. Organization, 10(3), 457-480.

Maruthappu, M., Hasan, A. \& Zeltner, T. (2015). Enablers and barriers in implementing integrated care. Health Systems \& Reform, 1(4), 250-256. https:// doi.org/10.1080/23288604.2015.1077301

Minas, R. (2016). The concept of integrated services in different welfare states from a life course perspective. International Social Security Review, 69(3-4), 85-107.

Minkman, M., Ahaus, K., Fabbricotti, I., Nabitz, U. \& Huijsman, R. (2008). A quality management model for integrated care: Results of a Delphi and Concept Mapping study. International Journal for Quality in Health Care, 21(1), 66-75.

Mintzberg, H. (1979). The structuring of organizations: A synthesis of the research. Englewood Cliffs, N.J.: Prentice-Hall.

Mur-Veeman, I., van Raak, A. \& Paulus, A. (2008). Comparing integrated care policy in Europe: Does policy matter? Health Policy, 85(2), 172-183. https://doi. org/10.1016/j.healthpol.2007.07.008

O’Toole, L. (2003). Interorganizational relations in implementation. I B.G. Peters \& J. Pierre (Red.), Handbook of public administration (s. 234-244). London: Sage.

O'Leary, R. \& Vij, N. (2012). Collaborative public management: Where have we been and where are we going? The American Review of Public Administration, 42(5), 507-522.

Osborne, S.P. (2002). Public-private partnerships: Theory and practice in international perspective. London: Routledge.

Osborne, S.P. (2006). The new public governance? Public Management Review, 8(3), 377-387.

Osborne, S.P. (2010). The new public governance: Emerging perspectives on the theory and practice of public governance. London: Routledge.

Ouwens, M., Wollersheim, H., Hermens, R., Hulscher, M. \& Grol, R. (2005). Integrated care programmes for chronically ill patients: a review of systematic reviews. International Journal for Quality in Health Care, 17(2), 141-146.

Parmigiani, A. \& Rivera-Santos, M. (2011). Clearing a path through the forest: A meta-review of interorganizational relationships. Journal of management, 37(4), 1108-1136.

Peters, B.G. \& Pierre, J. (1998). Governance without government? Rethinking public administration. Journal of Public Administration Research and Theory, 8(2), 223-243. 
Phillips, N., Lawrence, T.B. \& Hardy, C. (200o). Inter-organizational collaboration and the dynamics of institutional fields. Journal of Management Studies, 37(1).

Pollitt, C. (2003). Joined-up Government: A survey. Political Studies Review, 1(1), 34-49.

Powell, W.W. (1990). Neither market nor hierachy. Network forms of organization. Research in Organizational Behavior, 12, 295-336.

Provan, K.G., Fish, A. \& Sydow, J. (2007). Interorganizational networks at the network level: A review of the empirical literature on whole networks. Journal of management, 33(3), 479-516.

Provan, K.G. \& Milward, H.B. (2001). Do networks really work? A framework for evaluating public-sector organizational networks. Public Administration Review, $61(4), 414-423$

Radin, B.A. (2003). The instruments of intergovernmental management. I B.G. Peters \& J. Pierre (Red.), Handbook of public administration (s. 607-618). London: Sage.

Rhodes, R.A.W. (1996). The new governance: Governing without government. Political Studies, 44(4), 652-667.

Smith, M.J. (1993). Pressure, power and policy: State autonomy and policy networks in Britain and the United States. New York: Harvester Wheatsheaf.

Sullivan, H. \& Skelcher, C. (2002). Working across boundaries: Collaboration in public services. Basingstoke: Palgrave Macmillan.

Sullivan, H., Williams, P. \& Jeffares, S. (2012). Leadership for collaboration: Situated agency in practice. Public Management Review, 14(1), 41-66.

Thompson, G. (1991). Markets, hierarchies and networks: The coordination of social life. London: Sage.

Vabo, S.I. \& Røiseland, A. (2008). Governance på norsk: Samstyring som empirisk og analytisk fenomen. Norsk statsvitenskapelig tidsskrift, 24(1-2), 86-103.

Valentijn, P.P., Schepman, S.M., Opheij, W. \& Bruijnzeels, M.A. (2013). Understanding integrated care: A comprehensive conceptual framework based on the integrative functions of primary care. International Journal of Integrated Care, 13.

van Duijn, S., Zonneveld, N., Montero, A.L., Minkman, M. \& Nies, H. (2018). Service integration across sectors in Europe: Literature and practice. International Journal of Integrated Care, 18.

Vangen, S., Hayes, J.P. \& Cornforth, C. (2015). Governing cross-sector, interorganizational collaborations. Public Management Review, 17(9), 1237-126o. https://doi.org/10.1080/14719037.2014.903658

WHO (2015). WHO global strategy on people-centred and integrated health services: interim report. Geneva: WHO-World Health Organization.

Williams, P. \& Sullivan, H. (2010). Despite all we know about collaborative working, why do we still get it wrong? Journal of Integrated Care, 18(4), 4-15. 


\title{
KAPITTEL 2
}

\section{Organisering av individuell brukermedvirkning}

\section{Gunnar Vold Hansen}

\author{
Avdeling for helse og velferd, Høgskolen i Østfold
}

\begin{abstract}
Sammendrag: Brukermedvirkning er i dag et sentralt prinsipp i helse- og velferdssektoren. Noen ganger er tjenestene imidlertid organisert slik at dette er vanskelig å ivareta. I dette kapitlet ses det nærmere på hvordan organisering av beslutningsprosessene kan skape utfordringer for brukermedvirkningen. Det diskuteres hvordan brukermedvirkning kan forstås og analyseres. Ved hjelp av blant annet beslutningsteori og eksempler fra forskning trekkes det frem en del organisatoriske utfordringer for brukermedvirkning og hvordan disse kan løses. Kapitlet avsluttes derfor med en oppfordring til å være bevisst på at brukermedvirkningen må sikres ved at tjenesteyterne aktivt engasjerer seg for å legge til rette for at brukerne kan delta $\mathrm{i}$ beslutningsprosessene og fremme sine interesser.
\end{abstract}

Nøkkelord: brukermedvirkning, organisering og beslutningsprosesser

\section{Innledning}

Den klassiske beskrivelsen av en profesjonell var en person som hadde en faglig innsikt som gjorde at vedkommende kunne gjøre vurderinger på grunnlag av faglig skjønn. Dette faglige skjønnet var forankret i en kunnskap som ble beskrevet som esoterisk - det vil si at kunnskapen bare var forståelig bare for dem som hadde den gitte utdanningen (Freidson, 1988). Mange profesjonelle mente derfor at brukerne ikke hadde muligheter for å forstå de faglige vurderingene som ble foretatt, og at dette var en god begrunnelse for ikke å involvere brukerne når beslutninger skulle tas. Fra 1980-90-årene har dette gradvis endret seg. Helgesen og 
Hansen (2010) peker på at rekke utviklingstrekk bidro til dette. Blant annet fikk helse- og sosialfagutdanningene på midten av 1990-tallet nye rammeplaner der brukermedvirkning sto sentralt. Offentlig forvaltning ble dessuten på samme tid mer opptatt av å oppfatte brukerne som kunder. I tillegg ble mange lover endret, slik at brukerrettigheter ble både en plikt for tjenesteyterne og en rettighet for brukerne. Samlet bidro dette til en sterkere oppmerksomhet om brukermedvirkning. Dette har medført at mange ansatte i helse- og velferdssektoren nå er opptatt av å ivareta brukermedvirkning i det daglige arbeidet (Bjørkquist \& Hansen, 2018).

Brukermedvirkning handler likevel ikke bare om de ansattes holdning til brukerne. Noen ganger er tjenestene organisert slik at brukermedvirkningen er vanskelig å ivareta. Målsettingen med dette kapitlet er å vise at brukermedvirkning i stor grad er avhengig av å organisere beslutningsprosessene slik at brukerne kan ha reell innflytelse på de beslutningene som tas. Kapitlet tar utgangspunkt i tre eksempler på beslutningsprosesser. Problemstillingene er ulike, men alle viser hvilke utfordringer og muligheter som ligger i å sikre brukermedvirkningen. De tre eksemplene belyser brukermedvirkning ved overføring av brukere fra sykehus til kommune, ved organisering av tjenestetilbud i faste team og ved bruk av individuelle planer.

\section{Noen begrepsavklaringer}

\section{Brukere og tjenesteytere}

I dette kapitlet benyttes betegnelsen bruker om de som mottar eller skal motta en tjeneste fra helse- og velferdssektoren. Det kan være de som tjenesten er direkte rettet mot - de som gjerne kalles primærbrukere (pasienter og tjenestemottakere), og andre - de som kalles sekundærbrukere (for eksempel foreldre), og som indirekte nyter godt av tjenesten. Begrepene ansatte og tjenesteytere brukes delvis om hverandre. Ansatte kan være både tjenesteytere og andre ansatte (for eksempel saksbehandlere), men tjenesteytere er de som yter direkte brukerrettede tjenester. 


\section{Brukerperspektiv på samordning}

Hva man legger i et helhetlig og samordnet tjenestetilbud, vil for en stor grad være avhengig av hvilket perspektiv man har. Goodwin (2016) hevder at brukerne kun i begrenset grad er opptatt av hvordan tjenestene er organisert, og at de i større grad er opptatt av hvordan tjenestetilbudet ytes som et helhetlig tilbud. Derfor kan følgende være et eksempel på hvordan en bruker vil beskrive et samordnet og helhetlig tjenestetilbud: «Jeg kan planlegge mitt tjenestetilbud sammen med personer som samarbeider med meg og mine omsorgspersoner. Disse personene lar meg styre og samle tjenestene for å oppnå de resultatene som er viktige for meg» (Goodwin, 2016, s. 1). En slik forståelse av helhetlige tjenestetilbud forutsetter at brukerne har både en sentral og en aktiv plass i utformingen og gjennomføringen av tjenestene. Brukermedvirkning er derfor et av elementene som må oppfylles for at man skal få til en god samordning av helse- og velferdstjenester. Brukermedvirkning er likevel ikke et begrep som er entydig definert. Derfor er det nødvendig å avklare hva som menes med brukermedvirkning i denne sammenhengen.

\section{Ulike beskrivelser av brukermedvirkning}

I mange sammenhenger forklares brukermedvirkningsbegrepet ved hjelp av en skala. Allerede i 1969 beskrev Sherry R. Arnstein brukermedvirkning som delt inn i åtte stigetrinn. Modellen hennes er siden blitt kritisert for å fokusere ensidig på resultatene av brukernes medvirkning og i for liten grad ta hensyn til prosesser (se for eksempel Tritter \& McCallum, 2005). En rekke forfattere har derfor valgt å lage sine egne skalaer. Solheim og Rønning (1998, s. 37) refererer til Stromberg og beskriver i alt ni trinn på skalaen. Humerfelt (2005, s. 31) har også en slik skala, men begrenser seg til å beskrive totalt fem trinn. I denne sammenhengen er det ikke behov for en omfattende oppdeling av stigen, og det anses derfor som tilstrekkelig med en trapp med fire trinn (Hansen, 2007). Skalaen går fra liten grad av brukermedvirkning til stor grad av brukermedvirkning. De fire punktene er: brukerperspektiv, brukerdeltakelse, brukerinnflytelse og brukerstyring og kan synliggjøres i følgende modell: 


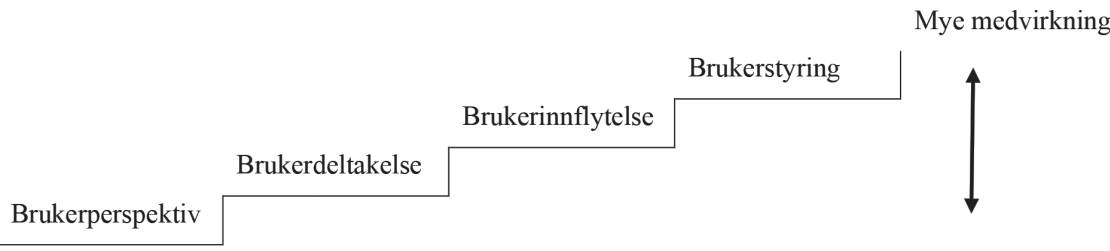

Figur 1. Brukermedvirkningstrappen.

De ulike trinnene i denne skalaen kan beskrives slik:

- Brukerperspektiv: Tjenestemottakernes interesser blir ivaretatt av hjelpeapparatet uten at brukerne deltar aktivt i selve beslutningsprosessen. Det innebærer at de ansatte selv definerer hvilke behov tjenestemottakeren har, og hvordan disse skal ivaretas best mulig. Det er altså ikke tjenestemottakeren selv som bestemmer noe, men de ansatte yter tjenester ut fra hvilke behov de tror at tjenestemottakeren har.

- Brukerdeltakelse: Tjenestemottakerne får delta i beslutningsprosessene, men har ikke nødvendigvis innflytelse over tiltakene som iverksettes. Dette kan være situasjoner der tjenestemottakeren får anledning til å delta i beslutningsprosessen, men der tjenesteyterne tar den endelige beslutningen. Dette gjelder for eksempel for en del ytelser som er regulert i et regelverk, og der tjenestemottakeren gis rettigheter til å uttale seg, men der det er tjenesteyteren som har retten til å konkludere hvorvidt grunnlaget for tjenesten er til stede. I slike situasjoner kan tjenestemottakeren komme med sine synspunkter og fremme de argumenter vedkommende måtte ha. Likevel er det de ansatte som sitter igjen med retten til å ta den endelige beslutningen.

- Brukerinnflytelse: Tjenestemottakerne får delta i beslutningsprosessene og har innflytelse over tiltakene som iverksettes. Dette er situasjoner der tjenestemottakerne både deltar i og har reell innflytelse på de beslutningene som tas. Likevel er det klart at hvor stor innflytelse tjenestemottakerne har, er avhengig av hvilke rammer som settes. Valg mellom to løsninger som begge oppleves som utilfredsstillende, vil være en svært snever form for brukerinnflytelse. Valg der rammene er vide, kan derimot gi stor grad av brukerinnflytelse. 
- Brukerstyring: Tjenestemottakerne deltar i beslutningsprosessen og har avgjørende innflytelse over hva som vedtas. Da er det tjenestemottakeren selv som tar beslutningene, og den ansatte blir bare den som utfører. Ordningen med brukerstyrt personlig assistent er ment å være en ordning der tjenestemottakeren selv har full styring.

En viktig tilnærming til brukermedvirkning finnes også i begrepet samproduksjon. I mange sammenhenger blir dette brukt som et løst begrep for å dekke mange ulike, men relaterte ideer. Selv om det ikke er enighet om en definisjon, kan følgende være et utgangspunkt som synes å dekke bruken i flere sammenhenger hvor man vektlegger «Ytelser av offentlige tjenester i et likeverdig og gjensidig forhold mellom fagfolk, brukere, deres familier og lokalsamfunnet» (Boyle \& Harris, 2009, s. 11). Tidligere ble samproduksjon benyttet om samarbeid som involverte bruker og tjenesteytere. I det senere har også pårørende samt frivillige organisasjoner blitt inkludert i begrepet (Askheim, 2016).

Torjesen mfl. (2017) mener at politiske føringer i Norge i stor grad legger opp til at brukermedvirkning skal foregå som samproduksjon. Dette innebærer at brukere ikke bare vil ha innflytelse på tjenestene de mottar, men at de også vil kunne være viktige aktører gjennom ulike faser i levering av tjenesten, som planlegging, utforming og tildeling (Bjørkquist \& Hansen, 2017). I noen tilfeller er det ikke praktisk mulig for brukerne å delta i levering av tjenestene - for eksempel ved kirurgiske inngrep. Likevel forventes det at brukermedvirkningen ivaretas ved at brukerne deltar i beslutningsprosessen om hva som skal gjøres. Dette kan gjøres gjennom et partnerskap mellom tjenesteytere og brukere (Coulter, 1999). Et begrep som illustrerer denne formen for partnerskap, er «Shared DecisionMaking» (delt beslutningstaking eller samvalg, som det også kalles). Storm og Edwards (2013) peker på at en slik prosess blant annet krever aktiv deltakelse fra både bruker og tjenesteyter samt en prosess der informasjonsdeling og reelle valg av løsninger er sentrale elementer. 
Vanligvis forventer man at en beslutningsprosess skal gi muligheter for å velge den beste løsningen, det som kalles en rasjonell beslutningsprosess. Hatch (2004) beskriver en slik prosess der utgangspunktet er en eller annen form for problemformulering - en oppgave som skal løses. Hva slags oppgave dette er, analyserer man seg frem til gjennom første ledd. Når man først har funnet ut hva som er problemet, gjelder det å finne frem til hvilken løsning man ønsker seg, og deretter formulere hva slags mål man har. På bakgrunn av dette finner man frem til hvilke alternativer som finnes - hvilke tiltak kan man iverksette for å nå målene og løse problemet. Man må så vurdere hvilke av de foreliggende alternativene som gir best måloppnåelse, og så velge det som er mest gunstig. I ettertid vil det være naturlig å vurdere om den valgte løsningen faktisk ga det resultatet man ønsket, og hvis ikke kan man begynne prosessen på nytt, men nå med erfaringene som er gjort, som ekstra datagrunnlag (Hatch, 2004, s. 301).

March og Olsen (1986, s. 13) skisserer - med bakgrunn i en slik tilnærming - følgende fire forutsetninger for en rasjonell beslutningsprosess:

- klare preferanser

- kjennskap til alternativene

- kjennskap til konsekvensene

- en tilfredsstillende beslutningsrutine

De ansatte har en forholdsvis stor grad av profesjonell frihet til å gjøre jobben slik de anser at den bør gjøres. Samtidig er ansatte i helse- og velferdssektoren utsatt for et nokså omfattende tidspress og har derfor begrensete muligheter for å gjennomføre en systematisk beslutningsprosess.

En alternativ måte å se beslutningsprosesser på er å se dem som et produkt av fire strømmer: beslutningssituasjoner, deltakere, problemer og løsninger (March, 1994). Hvilken beslutning man kommer frem til, er da et resultat av at deltakerne har en rekke problemer som de ønsker å finne en løsning på, ikke bare de problemene brukeren ønsker å få løst. Hver deltaker representerer også en rekke løsninger, og hvis de kan benytte ett av sine problemer som løsning for de andre, er det en fordel. Et eksempel kan være at en tjenesteyter har problemer med å rekruttere nok brukere 
til sitt tilbud. Da vil motivasjonen for å foreslå det tjenestilbudet som en løsning for brukeren, være stor. Hvorvidt man kommer frem til den mest optimale løsningen, vil derfor i stor grad være avhengig av at man - i tråd med kravene til March og Olsen (1986) - blir enige om mål, om fordelene med de ulike alternativene, og at man klarer å enes om en felles beslutning.

En av begrunnelsene for tverrfaglige møteplasser er nettopp at ulik bakgrunn kan skape større forståelse og generere løsninger som deltakerne hver for seg ikke kan se for seg (Freeman, 2008; Hudson, 2004). Er man bevisst på utfordringer og muligheter, kan slike møteplasser skape grunnlag for å utforske nye løsninger. For brukeren er det viktig at målsettinger, alternativer og mulige konsekvenser av de ulike løsningsforslagene blir tydeliggjort. Det innebærer at tjenesteyterne også må avsløre den usikkerheten som foreligger.

De fleste problemene i helse- og velferdssektoren kan beskrives som uregjerlige problemer (Vabø, 2014). Det vil si at det er problemer der blant annet årsakene er uklare, der det er uenighet om målene, og der det ikke finnes en bestemt riktig løsning (Rittel \& Webber, 1973). Uenighet om årsaker, mål og løsningsalternativer kan bidra til at en del beslutninger tas i «skjul», ved at tjenesteytere avgjør forhold innenfor sitt ansvarsområde uten å inkludere brukere og andre tjenesteytere. På den måten kan tjenesteyterne legge vekt på hva de selv mener er riktig tjenestetilbud, og unngå å forholde seg til felles mål (Hansen, 2007).

I helse- og velferdssektoren er det også en utfordring at brukerne ofte står i et avhengighetsforhold til tjenesteyterne. Det betyr at det ikke er en gjensidig maktbalanse mellom partene. En klassisk definisjon på makt er: "Makt forekommer når en aktør A får en aktør B til å gjøre noe hun eller han ellers ikke ville ha gjort» (Dahl, 1957, s. 202-203). I helse- og velferdssektoren ser vi at tjenesteyterne kan få brukerne til å handle annerledes enn de ellers ville ha gjort av flere grunner. Delvis kan dette skyldes direkte maktutøvelse, der tjenesteyterne (eller virksomhetene) nekter brukeren hjelp hvis ikke brukeren selv oppfyller visse krav. Det kan være formelle krav om at man må møte opp personlig hos legen for å få en sykemelding, eller mer direkte krav som at brukeren må være rusfri for å få en bestemt type hjelp. Vi kan også tenke oss at makt utøves 
mer indirekte ved at tjenesteyterne ikke setter noen bestemte krav, men hvor brukeren tilpasser seg de prioriteringene de tror at tjenesteyteren har, fordi brukeren vet at vedkommende er avhengig av bistand og derfor vil imøtekomme tjenesteyteren best mulig (Weber, 1971).

I dette kapitlet skal jeg vise at brukermedvirkning kan være et spørsmål om hvordan man organiserer beslutningsprosessene, ikke bare et spørsmål om hvordan den enkelte tjenesteyteren forholder seg til brukeren.

\section{Datasamling og analyse}

De eksemplene som presenteres her, bygger på data som er samlet inn i perioden fra 2004 til 2017. Datagrunnlaget er intervjuer med tjenesteytere og andre ansatte, samt observasjoner av ulike møter der det tas beslutninger om innholdet i tjenestene. Den viktigste datakilden har vært observasjoner, og det er gjennomført observasjon av i alt 28 ansvarsgruppe-/ samarbeidsmøter. I tillegg er det gjennomført intervjuer med nesten hundre ansatte. Aktiviteten i de ulike møtene ble registrert i et eget skjema som var utarbeidet spesielt for formålet (Hansen, 2007). Alle intervjuene ble tatt opp med digital opptaker, og de fleste ble transkribert fullt ut, men for en del av intervjuene ble bare de delene som etter en gjennomhøring ble ansett som interessante, skrevet ut.

Et sentralt spørsmål i denne sammenhengen er hvordan man skal måle brukermedvirkning. Den mest innlysende måten er selvfølgelig å spørre tjenestemottakerne. Det er en viss selvmotsigelse i å velge andre tilnærminger. Likevel kan det være vanskelig for brukerne å vurdere hvorvidt de har fått god nok informasjon til å gjøre selvstendige valg mellom foreliggende alternativer, og om de har vært utsatt for manipulering. En viktig del av grunnlaget for de konklusjonene som skisseres i dette kapitlet, er derfor observasjon av beslutningssituasjoner i ulike møter og analyse av om disse beslutningssituasjonene har ivaretatt de kravene som er skissert over.

Det første eksempelet handler om overføring av pasienter fra sykehus til kommunale rehabiliteringstilbud. Data som presenteres, bygger på syv gruppeintervjuer med i alt 25 personer ansatt henholdsvis ved et sykehus og i tre forskjellige kommuner. Tre av gruppeintervjuene var med 
ansatte på kommunenes tildelingskontorer, tre med ansatte på kommunens rehabiliteringsavdeling og ett med ansatte ved sykehuset. Det andre eksempelet handler om samarbeid mellom spesialisthelsetjenesten og kommunene om brukere med omfattende rusproblemer og psykiske lidelser. Data bygger på observasjoner av 13 ulike møter, først og fremst i samarbeidsgruppene. Umiddelbart etter at samarbeidsmøtene var gjennomført, ble hele gruppen intervjuet. Det ga oss mulighet til å få en mer detaljert bakgrunn og en dypere forståelse av de observasjonene som var gjort. I tillegg ble det gjennomført i alt seks individuelle intervjuer med sentrale aktører. Det siste eksempelet handler om utvikling av individuelle planer i psykisk helsetjeneste i to kommuner. Først og fremst bygger det på data som ble samlet inn ved å følge utviklingen av fire individuelle planer over en periode på ett år. I alt ble 15 ansvarsgruppemøter observert, og koordinatorene for disse planene ble intervjuet etter hvert møte. De kunne da utdype det som ble observert, og forklare hvorfor man hadde handlet som man gjorde. I det siste eksempelet benyttes også data fra to gruppeintervjuer: det ene med fem pårørende og det andre med fire brukere.

Selve analysen har i hovedsak vært deduktiv, ved at både observasjoner og intervjuutsagn er vurdert opp mot hvordan beslutningsprosessene har vært gjennomført, hvem som har deltatt, hvilken informasjon brukerne har fått, og om de har fått reelle muligheter til å velge løsninger.

\section{Brukermedvirkning i praksis}

\section{Eksempel 1 - Forløp ved overføring av bruker fra sykehus til kommunale tjenester}

Dette eksempelet bygger på et prosjekt som kartla en del av de utfordringene tre større kommuner og det regionale sykehuset hadde når det gjaldt samarbeid om rehabiliteringspasienter. Undersøkelsen viste at det var en rekke utfordringer knyttet til å skape et best mulig samordnet rehabiliteringstilbud. Én av dem handlet om å sikre at forløpet fra sykehuset til de kommunale rehabiliteringsavdelingene bidro til at brukerne fikk et best mulig tilpasset kommunalt tilbud. Et rehabiliteringstilbud skal være 
forankret både i brukerens egne ønsker og i en faglig vurdering av hvilke muligheter og behov brukeren har for å realisere disse ønskene. Gode rehabiliteringsprosesser må derfor forankres i brukermedvirkning.

Forløpet for rehabiliteringsbrukere var lagt opp slik at sykehuset sendte melding til kommunen når en person ble innlagt, og da behandlingen skulle avsluttes, ble det gitt ny beskjed til kommunen. Vanligvis kom henvendelsene fra sykehuset i form av et utfylt, standardisert skjema. På dette skjemaet kunne sykehuset blant annet beskrive brukerens situasjon og behov ved å krysse av på ulike skalaer. I tillegg hendte det ofte at sykehuset ga uttrykk for hvilket tilbud de mente brukeren hadde behov for. De anbefalingene som sykehuset ga, ble også fulgt opp av brukeren selv eller pårørende som henvendte seg til tildelingskontoret med ønske om å få det tilbudet sykehuset hadde anbefalt. Alle kommunene hadde et tildelingskontor som skulle fordele brukerne på tre ulike tilbud: oppfølging i hjemmet, kort- eller langtidsopphold i pleie- og omsorgsinstitusjon, eller et intensivt tilbud på en rehabiliteringsavdeling.

Undersøkelsen viste at overgangen fra sykehus til kommune i en rekke tilfeller var problematisk. For kommunen var det et problem at mange rehabiliteringspasienter fikk et tilbud som de ikke kunne nyttiggjøre seg fullt ut. For å løse dette tok alle tre kommunene i bruk en ordning der de møtte opp og intervjuet brukeren mens vedkommende fortsatt var innlagt på sykehuset. Det var en løsning som, til tross for at den var mer ressurskrevende, ga bedre tilpassete tilbud til brukerne.

I praksis er det to alternative beslutningsprosesser. Den ene bygger i hovedsak på skriftlig informasjon fra sykehuset til tildelingskontoret. På bakgrunn av denne informasjonen bestemmer tildelingskontoret hvilket kommunalt tjenestetilbud brukeren skal få. Alternativt bygger tildelingskontoret sine vurderinger både på informasjon fra sykehuset og på direkte kontakt med brukeren mens vedkommende fortsatt er på sykehuset.

Det er grunn til å stille spørsmål ved om brukermedvirkning kan ivaretas ved at sykehuset sender sine innspill skriftlig til tildelingskontoret. Selv om det er klart at innspillene sykehuset kommer med, for eksempel om at brukeren trenger sykehjemsplass eller rehabiliteringsopphold, er diskutert både med bruker og pårørende, er det usikkert om de bygger på reell brukermedvirkning. Det er avgjørende for brukermedvirkningen at 
brukeren har relevant informasjon og reelle alternativer å velge mellom (Askheim, 2007). Ansatte på sykehuset har begrenset kunnskap om det kommunale tjenestetilbudet. Den veiledningen de kan yte, vil derfor vanligvis være begrenset. Hvis sykehusansatte er den eneste informasjonskilden om de kommunale tilbudene, kan de ønskene brukeren og pårørende kommer med, være forankret i et informasjonsgrunnlag som ikke er tilstrekkelig. Da blir beslutningen ikke nødvendigvis i tråd med brukerens prioriteringer (March, 1994). I tillegg er det å formidle et ønske bare å anse som brukerdeltakelse, det innebærer ikke nødvendigvis noe innflytelse (Hansen, 2007). Det er en forutsetning for reell brukermedvirkning at det foregår gjensidig kommunikasjon mellom bruker og beslutningstaker (Storm \& Edvards, 2013; Vrangbæk, 2015). Skriftlig informasjonsutveksling er en lite avansert form for samarbeid (Andersson mfl., 2011). Dette skaper ikke godt nok grunnlag for reell utveksling av synspunkter mellom bruker og tjenesteyter for å komme frem til en omforent felles løsning.

Beskrivelsen av kontakten koordinatorene fra kommunen gir fra sine besøk hos bruker på sykehus før utskrivning, gir derimot et annet bilde. Koordinatorene beskriver hvordan de prøver å bli kjent med brukeren, gir vedkommende relevant informasjon og samarbeider om å finne et hensiktsmessig tjenestetilbud. Det må riktignok tas forbehold om at det ikke er data på hvordan brukerne selv opplever denne situasjonen. Uansett vil en direkte kontakt mellom bruker og kommune, mens brukeren fortsatt er på sykehuset, trolig ivareta brukermedvirkningen på en bedre måte enn uten en slik kontakt. Når bruker og en av beslutningstakerne møtes og utveksler informasjon, gir dette et bedre grunnlag for å gjennomføre en beslutningsprosess der også brukerens interesser ivaretas (Hansen, 2007). Likevel er det en svakhet ved denne løsningen. Den forutsetter at de ansatte ved tildelingskontoret har god nok innsikt i de tilbudene som brukerne kan velge mellom. Erfaringer fra andre kommuner tyder på at tildelingskontorer kan mangle tilstrekkelig innsikt i spesialiserte tjenestetilbud som rehabilitering, og at det dermed skaper usikkerhet med hensyn til om beslutningene som tas, er tilstrekkelig godt forankret i kunnskap og brukermedvirkning (Steihaug mfl., 2016).

Når tildelingskontoret avgjør hvilket tjenestetilbud brukeren skal få, på bakgrunn av en skriftlig henvendelse fra sykehuset, vil dette i beste fall være 
brukerdeltakelse i den skalaen som er skissert over. Når kommunens tildelingskontor møter opp på sykehuset, gir det brukeren større muligheter for å påvirke avgjørelsen i den retningen vedkommende ønsker. Under forutsetning av at kommunenes representant kan presentere aktuelle alternativer og forklare konsekvensene av de ulike løsningene, får brukeren muligheter til å forhandle med beslutningstakeren. Denne måten å organisere beslutningsprosessen på skaper dermed muligheter for brukerinnflytelse.

\section{Eksempel 2 - Samarbeidsteam uten brukerdeltakelse}

Dette eksempelet handler om opprettelse av faste team - kalt samhandlingsgrupper - som skulle sikre samarbeid mellom kommuner og en samarbeidende ruspoliklinikk og distriktspsykiatrisk senter (DPS). Det var i alt fem slike samhandlingsgrupper, og de var satt sammen slik at de hadde representanter for de to «søylene» i spesialisttjenesten: rustjenesten og psykisk helsevern samt ulike kommunale tjenester som rusarbeid og psykisk helsearbeid, NAV og fastlege. I begynnelsen hadde man møter én gang i uken, etter hvert ble dette redusert til hver annen eller hver tredje uke. Arbeidsformen var nokså lik i de ulike gruppene. På møtene gikk gruppen normalt gjennom situasjonen for alle de brukerne som var inkludert i prosjektet, om lag ti personer i hver kommune. Målsettingen var at man skulle kunne justere tilbudet raskt dersom gruppen så behov for det. Fordi man diskuterte flere brukere samtidig, mente man at det ville være brudd på taushetsplikten å la brukerne få delta på disse møtene, men fra flere av kommunene deltok det en erfaringskonsulent (en person med tidligere brukererfaring som var tilsatt i kommunen for å fremme brukernes interesser).

En god del av de spørsmålene som ble tatt opp, var forankret i henvisninger til brukernes egne ønsker, som f.eks. «Han sier at han vil ...». Ofte var det imidlertid også de ansattes vurderinger som var utgangspunkt for diskusjoner. Eksempelvis kunne det være utsagn som «etter min mening trenger hun ...». På bakgrunn av slike utsagn kunne gruppen diskutere seg frem til hvordan dette kunne løses, og hvem som skulle følge opp brukeren. Tjenesteyterne mente at de ivaretok brukermedvirkningen på to måter. For det første ved at brukerne alltid hadde muligheter til å si nei 
eller ja til de forslagene man hadde kommet frem til i samhandlingsgruppene. For det andre ble det hevdet at brukernes stemme var representert ved erfaringskonsulentens deltakelse.

Brukermedvirkning på individplan skulle i utgangspunktet ivaretas i ansvarsgruppene. Disse gruppene møtte mye sjeldnere enn samhandlingsgruppene (ansvarsgruppene to til fire ganger i året, samhandlingsgruppene om lag hver annen uke). Dessuten var det ikke alle som hadde en ansvarsgruppe rundt seg. Individuell brukermedvirkning, i form av deltakelse på beslutningsarenaen samhandlingsgruppen, manglet derfor. Dette kan man i teorien kompensere for ved å ha gode beslutningsprosesser der brukerne har en indirekte deltakelse. En del av de problemstillingene som ble tatt opp, ble initiert av de ansatte etter diskusjon med den enkelte bruker. I andre situasjoner var diskusjonene i samhandlingsgruppene initiert av ansvarsgrupper der brukeren hadde deltatt $\mathrm{i}$ avgjørelsen om å videreformidle saken til samhandlingsgruppen. Slik sett kan man anta at brukerne i noen tilfeller har vært med å formulere hvilke problemstillinger som skulle tas opp i samhandlingsgruppene, enten fordi de var formulert i ansvarsgrupper, eller direkte overfor en av de ansatte som hadde formidlet dem videre til samhandlingsgruppen. Likevel tydet diskusjonene i samhandlingsgruppene på at en stor del av problemstillingene ble initiert uten at brukerne var klar over det. Derfor er det grunn til å tro at brukerne bare i begrenset grad hadde innflytelse på hvilke spørsmål som ble tatt opp i samhandlingsgruppene (Trittle \& McCallum, 2006).

Den utvidete informasjonen som kom frem i samhandlingsgruppene, ble i noen tilfeller benyttet til å velge et alternativ som brukerne ble forelagt. På den måten har utvidet informasjon i samhandlingsgruppen blitt snevret inn til ett eller noen få konkrete forslag som brukerne er blitt forelagt. Dermed har de fătt et redusert informasjonsgrunnlag som basis for å delta i beslutningsprosessen, og en av de sentrale forutsetningene for reell brukerinnflytelse - tilstrekkelig informasjon - er ikke ivaretatt (Tait \& Lesser, 2005). Dette innebærer at brukerne enten ikke får være med på selve beslutningen om hvilken løsning som skal velges, eller at de får seg forelagt avgrensete løsningsforslag. Manglende informasjon om alternative behandlingsopplegg samt manglende innflytelse på valg av 
behandlingsopplegg oppleves som et stort problem for brukerne (Kjøllesdal \& Iversen, 2014).

Fordi brukerne ikke har deltatt i samhandlingsgruppene, har de i liten grad hatt muligheter for å skissere problemer og velge mellom aktuelle løsningsforslag (March, 1994). De beslutningene man er kommet frem til, er blitt forelagt brukerne - prosessen frem til dette har de hatt begrenset innflytelse på. I praksis innebærer dette at brukerne kun i liten grad har kontroll over problemer, deltar i diskusjonen om løsninger, deltar i beslutningsprosessen eller kan velge mellom aktuelle alternativer (March \& Olsen, 1986). I praksis har brukerne derfor ikke kontroll over noen av de faktorene som påvirker en beslutningsprosess.

Samhandlingsgruppene er bare ett av flere eksempler på hvordan man i dag velger å organisere samarbeidet i sektoren ved å opprette ulike former for faste team. Utfordringer som oppstår, forventes å bli løst ved at teammedlemmene i fellesskap finner frem til en løsning. Det er stor enighet om at team er en god og effektiv måte å organisere samarbeid mellom ulike virksomheter på (se f.eks. Hudson, 2004; Ferlie mfl., 2011; Head \& Alford, 2015). Mulighetene for at team blir en stadig mer populær organisasjonsform, er derfor til stede. Det foregår i dag omfattende forsøk med utvikling av nye samarbeidsmodeller. Det sentrale i disse utviklingsprosjektene synes i stor grad å handle om hvordan man skal få til gode og effektive møteplasser for de ulike tjenestene. Erfaringene fra dette eksempelet viser at man, til tross for de beste intensjoner, ikke har klart å ivareta den enkelte brukers deltakelse i beslutningsprosessene godt nok. Derimot er det klart at samarbeidet mellom de ulike tjenesteyterne i den aktuelle modellen er blitt klart bedre. Skal man oppnå brukerinnflytelse, må også slike utviklingsprosesser legge vekt på hvordan brukerne kan sikres deltakelse i teamenes beslutningsprosesser.

\section{Eksempel 3 - Brukerdeltakelse i ansvarsgrupper og ved individuelle planer}

Brukerdeltakelse i en beslutningsprosess bidrar ikke uten videre til brukerinnflytelse. Noen ganger er det av ulike grunner slik at brukerne, selv om de deltar i prosessen, har liten makt eller innflytelse over de 
beslutningene som tas. Det kan da være nødvendig å legge til rette for en form for maktutjevning mellom tjenesteytere og brukere. Dette skal illustreres med erfaringene fra arbeidet med individuelle planer i kommunalt psykisk helsearbeid. Innholdet i og justeringer av innholdet i de individuelle planene ble i hovedsak fastsatt i ansvarsgruppemøter. Selv om en del av beslutningene om hvilke tjenestetilbud brukeren skulle få, ble tatt andre steder, for eksempel på kommunens tildelingskontor, hadde deltakerne normalt gode muligheter til å justere tilbudet innenfor de gitte rammene. Datagrunnlaget for dette eksempelet er observasjoner av i alt 15 ansvarsgruppemøter, individuelle intervjuer med koordinatorene og gruppeintervjuer med brukere og pårørende.

Ansvarsgrupper og individuelle planer er en ordning som burde legge til rette for reell brukermedvirkning i form av direkte innflytelse på utformingen av tjenestetilbudet. En av målsettingene med en individuell plan er at den skal styrke samhandlingen mellom tjenesteyter og pasient/ bruker og eventuelt pårørende, og mellom tjenesteytere og etater innenfor et forvaltningsnivå eller på tvers av forvaltningsnivåene (Forskrift om habilitering og rehabilitering). Arbeidet med individuelle planer kobles derfor gjerne med ansvarsgrupper der både bruker, pårørende (hvis det er aktuelt) og de ulike tjenestene møtes med sikte på å planlegge og samordne tjenestetilbudet. I noen tilfeller etableres det ansvarsgrupper uten at det utarbeides en IP. Ansvarsgruppemøter, uansett om de kobles til IP eller ikke, vil i prinsippet være en arena der man kan legge til rette for brukermedvirkning gjennom samvalg.

Erfaringen med bruk av ansvarsgrupper er likevel ikke entydige. De eksemplene som trekkes frem her, viser at selv om brukerne deltok sammen med tjenesteyterne på disse møtene, var det ikke alle som hadde noen innflytelse over de beslutningene som ble tatt. Blant annet var det et problem at ansvarsgruppemøtene bare i begrenset grad ble brukt til å utforme en strategi og beslutte hvilke tjenester brukeren skulle ha. Det skyldtes delvis at de tjenesteyterne som deltok, ofte var mest opptatt av å rapportere om det som hadde skjedd. Slike rapporter kunne vært et godt datagrunnlag for en analyse av hva som var brukerens behov og utfordringer, men ingenting tydet på at de ble brukt på denne måten. I stedet dannet disse rapportene utgangspunkt for at de som kunne det, 
fortalte hva de hadde planlagt av tjenestetilbud fremover. Vurdering av alternativer skjedde sjelden. I hvilken grad brukerne hadde vært med på å planlegge de tiltakene som ble referert, var ikke klart. Målsettingen med ansvarsgrupper er uansett at de skal benyttes til å utarbeide samordnete tjenester. Hvis man skal utnytte det potensialet for bedre tjenester som ligger $\mathrm{i}$ at flere samarbeider om å finne det beste tilbudet (Hudson, 2004), må tjenestetilbudet diskuteres i fellesskap, og brukerne må ha innflytelse på de beslutningene som diskusjonen fører frem til.

I hvilken grad brukermedvirkningen ble ivaretatt i separate diskusjoner mellom hver enkelt tjenesteyter og brukeren, ble det ikke opplyst noe om på møtene. Det er helheten i tjenestetilbudet som er avgjørende for brukeren (Goodwin, 2016). Dette betyr at de ulike tiltakene må tilpasses hverandre, og at brukermedvirkning må innebære at brukeren gis anledning til å delta i og påvirke en slik tilpasning. På et av ansvarsgruppemøtene ble det diskutert hvordan man kunne tilpasse de ulike tjenestene til hverandre, men da ble det initiert av brukeren selv. Brukeren ga beskjed om at vedkommende på grunn av medisineringen ikke lenger kunne fortsette i jobben sin. Det medførte at de ulike deltakerne kom frem med en rekke gode forslag om hvordan jobb og medisinering kunne kobles, og man kom i fellesskap frem til en løsning som passet brukeren. Dette eksempelet illustrerer flere ting. For det første at medisineringen ikke var tilpasset brukerens jobbsituasjon. Dernest viste det at brukeren selv ikke hadde en god løsning på problemet. Samtidig viser eksempelet at ingen av tjenesteyterne hadde registrert problemet. Derfor var det først når man hadde en samlet diskusjon der både bruker og tjenesteytere deltok, at man kom frem til en løsning som ivaretok alle parter. Problemet ble dermed løst ved at brukeren fikk anledning til å beskrive det, deretter diskuterte man ulike løsninger i fellesskap, og brukeren fikk velge det løsningsalternativet som vedkommende mente var best.

I noen sammenhenger skaper en felles møteplass løsninger ingen av deltakerne kunne se for seg på forhånd. På et av ansvarsgruppemøtene ba brukeren, som blant annet var plaget med angst og ikke var særlig trygg i omgang med ukjente, om at noen kunne følge ham til søndagsgudstjenesten i kirken. Pleie- og omsorgssektoren ga klart uttrykk for at deres tjenester var sterkt begrenset i helgene, og at de ikke kunne 
prioritere et slikt tiltak. En av de andre (en NAV-ansatt) kunne da fortelle at han gikk i kirken hver søndag, og gikk forbi brukerens bolig på veien, så han kunne gjerne ta brukeren med i kirken. Dette illustrerer hvordan slike møter skaper løsninger som ingen hadde sett for seg på forhånd (Freeman, 2008).

I noen ansvarsgruppemøter fikk man en diskusjon både av strategi og av konkrete tiltak. Dette skjedde der det var en bruker som var bevisst og som hadde klare prioriteringer, og derfor satte krav til tjenestene. En del av disse kravene ville ikke tjenestene innfri. Det satte i gang en interessant prosess fordi brukeren fikk støtte av den som var koordinator for den individuelle planen. Denne koordinatoren prøvde å underbygge brukerens argumentasjon, og da det ikke gikk, forsøkte vedkommende å finne frem til ulike kompromisser. Dette illustrerer et poeng som stadig flere er opptatt av, nemlig hvordan enkelte tjenesteytere tar rollen som «advokat» eller talsperson for brukere (Bjørkquist \& Hansen, 2018; Tahan, 2005).

Aktiv støtte til brukeren fra en eller flere av tjenesteyterne i en ansvarsgruppe handler også om makt. I en diskusjon mellom en bruker og en tjenesteyter vil makten normalt ligge hos tjenesteyteren (Stang, 1998). Når andre tjenesteytere støtter brukeren, kan maktforholdene utjevnes. På den annen siden kan en situasjon der brukeren blir stående alene mot alle tjenesteyterne, svekke brukerens innflytelse. Et alternativ er derfor å sørge for at brukeren har en talsperson som uansett støtter ham eller henne. I gruppeintervjuet med brukere fremhevet flere at de hadde positive erfaringer med å ha en støttespiller (gjerne en tillitsvalgt i en brukerorganisasjon), både i ansvarsgrupper og ellers der det var mulig å fremme brukermedvirkning. Noen ganger kan det også være hensiktsmessig å profesjonalisere denne støttefunksjonen. En pårørende som hadde bistått som hjelpeverge for et familiemedlem, fortalte at vedkommende opplevde store utfordringer med å bli tatt alvorlig av de profesjonelle $\mathrm{i}$ ansvarsgruppen. Dette endret seg betraktelig da hjelpevergefunksjonen ble overtatt av en betalt verge. Dette var en person som kjente både mulighetene og systemet godt, og kunne derfor diskutere med de profesjonelle tjenesteyterne på likt plan. Det innebar at denne vergen kunne formidle brukerens ønsker og argumentere for disse på en måte som tjenesteyterne tok seriøst. Den pårørende mente at tjenestetilbudet hadde blitt mer 
brukerorientert og bedre etter dette. Den betalte vergen fungerte her som en talsperson som kunne fremme brukerens interesser. Maktubalansen som kan oppstå i en situasjon der en bruker møter en gruppe tjenesteytere, kan dermed utjevnes noe ved at brukeren har med seg en talsperson. Det skyldes blant annet at brukeren får tilgang til alternative argumenter og opplysninger, og derfor får et bedre grunnlag for å prioritere mellom ulike alternativer. Vi skal heller ikke se bort fra at opplevelsen av ikke å stå alene mot alle andre, bidrar til at brukeren føler seg tryggere på sine egne argumenter. Et viktig poeng her er om den som fungerer som talsperson, er en del av tjenestene eller ikke. Undersøkelser viser at mange tjenesteytere opplever at de møter en rekke barrierer, som lojalitet til tjenestene og press fra kollegaer, når de skal fungere som brukerens talsperson (Oliveira \& Tariman, 2017). Talspersoner som ikke er en del av tjenestene, har trolig større muligheter for å håndtere slike barrierer.

\section{Oppsummering}

Utgangspunktet i dette kapitlet var en beskrivelse av hva som er viktig for brukerne ved samordning av helse- og velferdstjenester. Beskrivelsen innebærer at tjenestene må organiseres slik at brukerne gis en sentral rolle i å utforme tjenestetilbudet, og at det må legges stor vekt på brukermedvirkning. I den forståelsen som er lagt til grunn her, oppnås brukermedvirkning først når det eksisterer en form for samarbeid mellom brukere og tjenesteytere om de beslutningene som skal tas. Det medfører at brukerne må få en reell rolle i beslutningsprosessene. Dessverre er det ikke gitt at alle beslutningsprosesser organiseres slik at brukerne får anledning til å delta. I slike tilfeller er det vanskelig å se at brukermedvirkningen ivaretas på en forsvarlig måte. Det er heller ikke gitt at om brukerne deltar i en beslutningsprosess, så får de innflytelse på beslutningene. Ulike former for støtte til brukere som deltar i en beslutningsprosess, synes å gi dem et vesentlig bedre grunnlag for å fremme sine synspunkter og gi dem reell innflytelse på utformingen av tjenestetilbudet. Slik vi ser det, innebærer dette at dersom man skal oppnå brukerinnflytelse, må beslutningsprosessene organiseres slik at brukerne får delta. Brukerne må også gis tilstrekkelig støtte slik at de får tilgang til alternative argumenter og hjelp til å 
fremme sine synspunkter overfor andre deltakere i beslutningsprosessen. Også tjenesteyterne må være bevisst på hvordan de må oppføre seg for å skape grunnlag for bedre brukermedvirkning. Den klassiske profesjonelle ekspertrollen bør derfor tones ned til å bli mer som en rådgiverrolle, og i noen tilfeller kan tjenesteyteren bli brukerens talsperson.

\section{Referanser}

Andersson, J., Ahgren, B., Axelsson, S.B., Eriksson, A. \& Axelsson, R. (2011). Organizational approaches to collaboration in vocational rehabilitation-an international literature review. International Journal of Integrated care, 11(4), 1-10. https://doi.org/s10.5334/ijic.670

Arnstein, S.R. (1969). A ladder of citizen participation. Journal of the American Institute of planners, 35(4), 216-224.

Askheim, O.P. (2007). Empowerment-ulike tilnærminger. I O.P. Askheim \& B. Starrin (Red.), Empowerment i teori og praksis (s. 21-33). Oslo: Gyldendal Akademisk.

Askheim, O.P. (2016). Samproduksjon som velferdssektorens kinderegg. Tidsskrift for omsorgsforskning, 2(01), 24-36.

Bjørkquist, C. \& Hansen, G.V. (2017). Samproduksjon med pårørende til personer med ROP-lidelser. Tidsskrift for omsorgsforskning, 3(03), 194-203.

Bjørkquist, C. \& Hansen, G.V. (2018). Reducing service barriers to people with dual diagnosis in Norway. Cogent Social Sciences (OASS). https://doi.org/10.1080/23311 886.2018.1561237

Boyle, D. \& Harris, M. (2009). The challenge of co-production. London: New Economics Foundation.

Coulter A. (1999). Paternalism or partnership? Patients have grown up-and there's no going back. BMJ (Clinical research ed.), 319(7212), 719-20.

Dahl, R.A. (1957). The concept of power. Behavioral Science, 2(3), 201-215.

Ferlie, E., Fitzgerald, L., McGivern, G., Dopson, S. \& Bennett, C. (2011). Public policy networks and 'wicked problems': A nascent solution? Public Administration, $89(2), 307-324$.

Forskrift om habilitering og rehabilitering, individuell plan og koordinator, https:// lovdata.no/dokument/SF/forskrift/2011-12-16-1256 lest 19.12.2018.

Freeman, R. (2008). Learning by meeting. Critical Policy Analysis, 2(1), 1-24.

Freidson, E. (1988). Professional powers: A study of the institutionalization of formal knowledge. Chicago: University of Chicago Press.

Goodwin N. (2016). Understanding integrated care. International Journal of Integrated Care. 16(4):6. https://doi.org/10.5334/ijic.2530 
Hansen, G.V. (2007). Samarbeid uten fellesskap - om individuelle planer i kommunalt psykisk helsearbeid, Karlstad University Studies 2007:15.

Hatch, M.J. (2001). Organisasjonsteori: moderne, symbolske og postmoderne perspektiver. Oslo: Abstrakt forlag.

Head, B.W. \& Alford, J. (2015). Wicked problems: Implications for public policy and management. Administration \& Society, 47(6), 711-739.

Helgesen, M.K. \& Hansen, G.V. (2010): Public Action Empowerment, Synthesis Report, www.knowandpol.eu

Helse- og omsorgsdepartementet (2015). Nasjonal helse- og sykehusplan (2016-2019). (Meld. St. 11 (2015-2016)). Oslo: Helse- og omsorgsdepartementet.

Hudson, B. (2004). Analysing network partnerships: Benson re-visited. Public Management Review, 6(1), 75-94. https://doi.org/10.1080/14719030410001675740

Humerfelt, K. (2005). Begrepene brukermedvirkning og brukerperspektiv: Honnørord med lavt presisjonsnivå. I E. Willumsen (Red.), Brukernes medvirkning - kvalitet og legitimitet $i$ velferdstjenestene (s. 15-33). Oslo: Universitetsforlaget.

Kjøllesdal, J.G. \& Iversen, H.H. (2014). Pasienters erfaringer med døgnopphold innen psykisk helsevern. Resultater etter en landsdekkende undersøkelse i 2014. PasOpprapport - Brukererfaringsundersøkelse nr. 9 - 2014. ISBN 978-82-8121-909-o ISSN 1890-1565.

March, J.G. (1994). A primer on decision making. How decisions happen. New York: Free Press.

March, J. \& Olsen, J.P. (1986). Garbage can models of decision making in organizations. I J. March \& R. Weissinger-Baylon (Red.), Ambiguity and Command (s. 11-35). Marshfield, MA: Pitman.

Oliveira, C. \& Tariman, J.D. (2017). Barriers to the patient advocacy role: An integrative review of the literature. Journal of Nursing Practice Applications \& Reviews of Research, 7(2), 7-12.

Rittel, H. \& Webber, M. (1973). Dilemmas in a general theory of planning. Policy Sciences, 4(2), s. 155-169. https://doi.org/10.1007/bfo1405730

Ryan, B. (2012). Co-production: Option or obligation? Australian Journal of Public Administration, 71(3), 314-324. https://doi.org/10.1111/j.1467-8500.2012.00780.x

Rønning, R. \& Solheim, L.J. (1998). Hjelp på egne premisser?: om brukermedvirkning $i$ velferdssektoren. Oslo: Universitetsforlaget.

Stang, I. (1998). Makt og bemyndigelse. Oslo: Universitetsforlaget.

Steihaug, S., Johannessen, A.K., Ådnanes, M., Paulsen, B. \& Mannion, R. (2016). Challenges in achieving collaboration in clinical practice: The case of Norwegian health care. International Journal of Integrated Care, $16(3)$.

Stokmo, H., Ness, O., Borg, M. \& Sommer, M. (2014). Helsearbeidernes erfaringer med hvordan krav om modelltrofasthet virker inn på brukermedvirkning i ACTteam. Tidsskrift for psykisk helsearbeid, 11(01), 14-23. 
Storm, M. \& Edwards, A. (2013). Models of user involvement in mental health. Patient-centred health care: Achieving co-ordination, communication and innovation. Psychiatric Quarterly, 84(3), 313-32 214. https://doi:10.1057/978113730 8931_17

Tahan, H.A. (2005). Essentials of advocacy in case management. Professional Case Management, 10(3), 136-145.

Torjesen, D.O., Aarrevaara, T., Time, M.S. \& Tynkkynen, L.K. (2017). The users' role in primary and secondary healthcare in Finland and Norway. Scandinavian Journal of Public Administration, 21(1), 103-122.

Tritter, J.Q., \& McCallum, A. (2006). The snakes and ladders of user involvement: Moving beyond Arnstein. Health Policy, 76(2), 156-168.

Vabø, M. (2014). Dilemmaer i velferdens organisering. I M. Vabø \& S.I. Vabo (Red.), Velferdens organisering (s. 11-28). Oslo: Universitetsforlaget.

Vrangbæk, K. (2015). Patient involvement in Danish health care. Journal of Health Organization and Management, 29(5), 611-624. https://doi.org/10.1108/JHOM-012015-0002

Weber, M. (1971): Makt og byråkrati - essays om politikk og klasse, samfunnsforskning og verdier. Oslo: Pax Forlag. 



\title{
Tverrprofesjonelt samarbeid i ulike styringskontekster - hverdagsrehabilitering som eksempel
}

\author{
Mia Vabø \\ NOVA, Senter for velferds- og arbeidslivsforskning, OsloMet - \\ storbyuniversitetet
}

\begin{abstract}
Sammendrag: Tverrfaglighet og tverrprofesjonelt samarbeid er blitt et mantra i helse- og omsorgstjenestene. Bak begrepene skjuler det seg imidlertid varierende praksiser. Det varierer hvem som samarbeider, om hva, i hvilken fase av tjenesteforløpet og ut fra hvilken hensikt. Med eksempler fra hverdagsrehabilitering i to kommuner viser jeg hvordan slike variasjoner henger sammen med ulike styringskrav og styringssystemer. Jeg viser hvordan en likelydende idé om et tverrfaglig samarbeid ble fortolket i lys av kommunenes ulike styringsambisjoner, og hvordan omfanget og formen for samarbeid ble preget av ulike forvaltningsstrukturer, ulik tildelingspraksis og ulik tiltro til faglig skjønn. Med henvisning til disse ulikhetene argumenterer jeg for at det på ingen måte er entydig og gitt hva et tverrprofesjonelt samarbeid innebærer. Det er heller ikke gitt at det er noe selvinnlysende fordelaktig. En må alltid reise spørsmål ved hvilken hensikt det tverrprofesjonelle samarbeidet skal tjene, og for hvem det eventuelt vil være en fordel.
\end{abstract}

Nøkkelord: tverrprofesjoneltsamarbeid,praksislæring,styringsbetingelser,hverdagsrehabilitering

\section{Innledning}

Med en aldrende befolkning og stadig flere som lever med kroniske og sammensatte lidelser, anbefaler norske helsemyndigheter at ressurser fra ulike fagdisipliner koordineres og utnyttes bedre (Helse- og

Sitering av dette kapitlet: Vabø, M. (2019). Tverrprofesjonelt samarbeid i ulike styringskontekster - hverdagsrehabilitering som eksempel. I C. Bjørkquist \& M. Jerndahl Fineide (Red.), Organisasjonsperspektiv på samordning av helse- og velferdstjenester (s. 69-94). Oslo: Cappelen Damm Akademisk. https://doi.org/10.23865/ noasp.66.ch3.

Lisens: CC BY 4.0 
omsorgsdepartementet, 2014). Ambisjonen om å skape helhet og sammenheng på tvers av faggrenser er ikke noe nytt. I et spesialisert helsevesen har det vært en vedvarende utfordring å unngå at ulike profesjoner opererer innfor sine egne «lukkede» kunnskapssiloer. Det som likevel er nytt, er at idealer om tverrfaglighet og tverrprofesjonelt samarbeid nå løftes opp på et ideologisk og politisk nivå som del av en strategi for å utnytte helsevesenets fagressurser på en mer kostnadseffektiv måte (Lehn-Christensen, 2016). Ifølge WHO kan ikke presset på helsevesenet dempes utelukkende gjennom økt tilgang på personell. Det vil i tillegg kreve at både utdanninger og praksis i større grad legger til rette for samarbeid på tvers av ulike disipliner. Tverrprofesjonell samarbeidslæring i utdanningene anbefales både av norske myndigheter (Kunnskapsdepartementet, 2011) og av Verdens helseorganisasjon (WHO, 2010), og regnes både nasjonalt og internasjonalt som et vesentlig element $i$ et mer integrert og personsentrert tjenestetilbud (Helse- og omsorgsdepartementet, 2014; WHO, 2015).

I likhet med tidligere populære ledelses- og organisasjonstrender blir tverrfaglighet og tverrprofesjonelt samarbeid ofte omtalt som noe selvinnlysende positivt, noe som bør optimeres. Mye av det som skrives om emnet, er handlingsforeskrivende eller rettet mot å dokumentere effekter. Det er ikke så mye som handler om å få en dypere forståelse av hva som menes med tverrprofesjonelt samarbeid, og om hvordan ulike former for tverrprofesjonelt samarbeid utfoldes i praksis innenfor ulike strukturelle og institusjonelle rammer (Barr, 2013; Højholdt, 2016; Lehn-Christensen, 2016; Paradis \& Whitehead, 2015). Et unntak er Lehn-Christensen (2016) som, gjennom å undersøke hvordan fagfolk i helsevesenet selv anvender begrepet, konkluderer med at det er et generelt og flertydig begrep. Det er bred enighet om at det dreier seg om å koble sammen kunnskap fra ulike disipliner. Praksis viser imidlertid at sammenkoblingen kan foregå på ulike måter. Det kan skje gjennom jevnbyrdige eller hierarkiske samarbeid (Lehn-Christensen, 2016), gjennom et mer eller mindre integrert teamarbeid, gjennom en form for overlevering i et behandlingsforløp eller ved å utnytte hverandres ressurser i et løst nettverk (Højholdt, 2016). Det varierer også hva som vektlegges som mål og mening med det tverrprofesjonelle samarbeidet. Lehn-Christensen (2016) viser hvordan det begrunnes med utgangspunkt i ulike rasjonaler (fornuftsgrunnlag). 
Ofte anlegges et problemløsningsrasjonale, der det argumenteres for at innsikt fra flere fag er nødvendig for å løse komplekse problemer, og et pasientsentreringsrasjonale, der det argumenteres for at et tverrprofesjonelt samarbeid vil sikre en mer helhetlig forståelse av pasientens helseproblem. Hun viser også til hvordan samarbeid på tvers av fagfelt begrunnes med utgangspunkt i et profesjonaliseringsrasjonale, der det vektlegges at et samarbeid vil fremme gjensidig læring og dermed bidra til faglig utvikling. Profesjonaliseringsrasjonalet assosieres med et demokratisk ideal og et paradigmeskifte som tar til orde for et likeverdig samarbeid, der profesjonsutøvere søker å overskride innbyrdes forskjeller til beste for pasienten (D’Amour \& Oandasan, 2005). Ifølge Lehn-Christensen kan idealet stå i kontrast til et systemoptimaliseringsrasjonale, der argumentet er at tverrprofesjonelt samarbeid kan betraktes som en kilde til bedre utnyttelse av faglige og økonomiske ressurser i et presset helsevesen. Det siste rasjonalet åpner opp for en nivellering av faglighet via en forestilling om at sentrale oppgaver kan delegeres og løses av flere faggrupper.

Flertydigheten som omgir ideen om «tverrprofesjonelt samarbeid», tilsier at vi har å gjøre med et fenomen som kan oversettes til praksis på mange ulike måter. Skal vi få mer kunnskap om hvordan det offentlige tjenesteapparatet i praksis blir berørt av ideene, er det derfor nærliggende å undersøke nærmere hvordan ideen blir fylt med meningsinnhold i konkrete kontekster. Karl Weick (1995) kaller slike meningsskapende prosesser for sensemaking. ${ }^{1}$ Meningsskapende prosesser skjer ikke i et sosialt vakuum, men veves inn i en historisk og institusjonell kontekst (Weber \& Glynn, 2006).

I dette kapitlet retter jeg søkelyset mot tverrprofesjonelt samarbeid og viser hvordan begrepet tilskrives ulikt meningsinnhold innenfor rammen av ulike styringskontekster. Det empiriske grunnlaget er hentet fra en undersøkelse omkring hverdagsrehabilitering (HVR heretter), en form for hjemmebasert rehabilitering der flere faggrupper samarbeider om å bistå personer med trening og tilrettelegging av hverdagsaktiviteter. De

$1 \quad$ Sensemaking skjer kontinuerlig og retrospektivt i den forstand at man stadig forsøker å rettferdiggjøre egne handlinger. Weick bruker begrepet enactment som en betegnelse på at ideer og begreper (tanker) og iverksettingen av ideer er to sider av samme sak. Å skape mening er både en individuell og en sosial prosess. Den forutsetter menneskelig kognisjon, men vil alltid ha et kollektivt preg, ettersom den inngår i en sosial kontekst. 
to kommunene som deltok i undersøkelsen, var inspirert av den samme generelle ideen om HVR, men fortolket og oversatte ideen forskjellig, herunder også oppfatninger omkring hvordan ulike fagfolk skulle bidra i et samarbeid. Jeg ønsker her å vise hvordan ulike forståelser og praksiser omkring tverrprofesjonelt samarbeid kom til uttrykk i de to kommunene, og hvordan disse ble preget av at de ble iverksatt innenfor rammen av ulike styringssystemer og styringskrav.

Før jeg går dypere inn i den empiriske redegjørelsen, skal jeg innlede med å si litt om distinksjonen mellom ulike styringsmodeller norske kommuner har vært inspirert av, og litt om hvilken rolle profesjonene er blir tilskrevet innenfor hver av modellene. I dette avsnittet utdyper jeg også kort hvordan styringsmodellene kan tenkes å sameksistere.

\section{Velferdsprofesjonenes rolle og legitimitet innenfor ulike forvaltningsmodeller}

Når det er snakk om ulike modeller for offentlig styring, blir det ofte vist til Stephen Osbornes distinksjon mellom klassisk Public Administration (PA), New Public Management (NPM) og New Public Governance (NPG) (Osborne, 2010). De tre modellene baserer seg på ulike styringslogikker og på ulike og til dels motstridende syn på profesjonenes rolle (Brandsen \& Honingh, 2013).

(1) Den klassiske administrasjonsmodellen (PA), som dominerte i velferdsstatens utbyggingsfase, baserer seg på en form for styring der maktutøvelse legitimeres med utgangspunkt i demokratisk vedtatte regler og profesjonalisert yrkeskompetanse. Selv om ikke velferdsprofesjonene hadde den samme friheten som de tradisjonelt frittstående profesjonene (legene og juristene), utøvde de betydelig grad av faglig skjønn, ettersom de ble ansett å inneha den kunnskapen som var nødvendig for å nå velferdspolitiske mål. PA-modellen ble etter hvert kritisert for å tilskrive de profesjonelle en for beskyttet rolle. Kritikerne pekte på at profesjonsutøvernes faglige perspektiver ikke nødvendigvis sammenfalt med brukernes interesser (Brandsen \& Honingh, 2013; Flynn, 1999; Osborne, 2010). 
(2) Den markedsinspirerte styringsmodellen (NPM) ble på flere måter tuftet på denne skepsisen til profesjonene. Tanken var å skape et korrektiv til profesjonsmakten gjennom å sette «kundens» interesser i høysetet. Offentlige byråkratier skulle gjenskapes i bedriftens og markedets bilde gjennom å styres ved hjelp av klare bestillinger og kvalitetskrav. Dette innebar at det ble opprettet et skille mellom forvaltningen som bestiller (stiller krav til) tjenesten, og den som utfører tjenesten. I tillegg ble det skapt en oppsplitting i ulike resultatenheter som skulle underlegges kontroll og prestasjonsmålinger. Aller helst skulle resultatenhetene utsettes for konkurranse - enten i en myk form basert på sammenligninger (benchmarking) eller gjennom å utfordres av «ekte» private tilbydere (Vabø, 2007).

NPM skapte et insentiv for at de ulike driftsenhetene skulle konsentrere seg om å oppfylle egne prestasjonsmål. Kritikken mot NPM har blant annet vært at dette har gjort tjenestene «innadvendte» og mer opptatt av måloppnåelse i egen resultatenhet framfor i de totale velferdsløsningene. NPM ble beskyldt for å bidra til en fragmentering av tjenesteapparatet. Dette skapte igjen et behov for å samordne ulike tjenester - «lime sammen» det som er oppsplittet (Christensen \& Lægreid, 2007; Newman, 2001).

(3) På samme måte som NPM betraktes som en samlebetegnelse for bedriftsinspirerte styringsoppskrifter (Vabø, 2007), blir NPG i dag lansert som en samlebetegnelse for en rekke initiativer orientert mot å få til gode velferdsløsninger $p a ̊$ tvers av etater og sektorer (Koppenjan, 2012). NPG-tiltak er - i motsetning til typisk intraorganisatoriske NPM-tiltak - orientert mot et bredere interorganisatorisk nedslagsfelt. Torfing, Sørensen \& Røiseland (2016) anvender betegnelsen co-creation for å understreke at det dreier seg om å skape velferdsløsninger i samarbeid med borgere og tjenesteytere som opererer utenfor det offentlige styringsfeltet. NPG er en form for pragmatisk selvstyring i nettverk, der løsningen på problemer krever kommunikasjon og tillit like mye som spesifikk kunnskap (Brandsen \& Honingh 2013). I Norge kommer ideen til uttrykk dels via sentrale politiske dokumenter som den såkalte Hagen-rapporten 
(NOU 11: 2011) og dels via utviklingsprogrammer og håndbøker om innovasjon (Kobro, 2018).

Det har vært hevdet at sistnevnte styringstrend vil styrke profesjonenes posisjon gjennom å understøtte nye profesjonsidealer om collaborative professionalism (Adler, Kwon \& Heckscher, 2009) eller multi-professionalism (Noordegraaf, 2011). Enkelte hevder at profesjonsutøvere dermed også spiller en nøkkelrolle i å fremme NPGideene (se også Burau, Carstensen, Lou \& Kuhlman, 2017; Hudson, 2002; Suddaby \& Viale, 2011). Ifølge Brandsen \& Honingh (2013) er imidlertid styringstrenden foreløpig så ung at det er vanskelig å si noe klart om hvordan den faktisk berører profesjonenes posisjon. Forfatterne antyder at styringsidealet like gjerne kan true profesjoners rolle, ettersom tverrprofesjonelt samarbeid også åpner opp for at deres allment aksepterte kunnskapsbase blir utfordret og dermed svekket. De bygger med andre ord på et systemoptimeringsrasjonale som legger til grunn at man, innenfor et presset helsevesen, vil forsøke å «tøye» personalets faglighet og kompetanse i håp om å få mest mulig igjen for knappe ressurser (Lehn-Christensen, 2016, s. 63).

\section{Hvordan skifter styringstrender?}

Selv om de tre styringsmodellene ofte presenteres som trender som etterfølger hverandre i kronologisk rekkefølge, blir det advart mot å forstå dem i lys av en strengt definert faseteori, der den ene modellen byttes ut med en ny. Det som i praksis ofte skjer, er at de ulike styringslogikkene overlapper hverandre og sameksisterer - noen ganger i et vanskelig spenningsforhold (Newman, 2001). Forskning fra den kommunale omsorgstjenesten har vist at endringstiltak med utspring i NPM noen ganger sporer av i uintenderte retninger når de «legges ovenpå» en klassisk profesjonsbyråkratisk organisasjon (Vabø, 2007, 2014). Stramme NPMinspirerte styringstiltak har blitt myket opp og tilpasset gjeldende praksis, eller de har blitt «paret med» statlige prosedyrekrav, slik at de i virkeligheten har bidratt til mer papirarbeid og «byråkrati» - ikke mindre, slik NPM-tilhengere ofte vil hevde (Vabø, 2014). 
Det er nærliggende å tro at tilsvarende spenninger vil oppstå når det nå i økende grad tas initiativer til å iverksette ideer om NPG. Erfaringer fra Storbritannia har vist at forsøk på å stimulere offentlige tjenesteytere til å inngå i samarbeidsnettverk i noen tilfeller hemmes av at de i for stor grad er «låst» til NPM-inspirerte rapporteringssystemer (Newman, 2001). Ifølge Torfing mfl. (2016) krever iverksetting av NPG noe mer enn god vilje. Det krever i tillegg en rekke systemendringer. Forfatterne nevner blant annet at det vil være nødvendig med en mer tverrprofesjonell tenkning. Om en skal få til samskaping, bør det legges til rette for dialog, åpenhet og nysgjerrighet på tvers av profesjoner. Man bør altså bryte med tradisjonelle forestillinger om at visse profesjoner besitter «hellig» og ubestridelig kunnskap. Dersom man ønsker å stimulere til at ulike aktører utveksler ressurser og lærer av hverandre, er det også viktig å dempe anvendelsen av prestasjonsmålinger og i stedet legge større vekt på horisontal og profesjonell ansvarsutkreving (accountability). Dette vil igjen forutsette at en nullfeilkultur og et kortsiktig perspektiv på effektiv problemløsning dempes til fordel for en mer risikovillig kultur og et mer langsiktig perspektiv på hva som er gode løsninger.

Hvorvidt initiativer til ulike former for samskaping virkelig ledsages av denne typen systemendringer, er på ingen måte gitt (Torfing mfl., 2016). I sin undersøkelse av hvordan ledere takler misforhold mellom etablerte styringskontekster og nye ideer, argumenterer Termeer (2009) for at endringsprosesser bør analyseres med utgangspunkt i Weicks begrep om sensemaking - det vil si med søkelys på hvordan ideer formuleres og iverksettes slik at de framstår som logiske og meningsfylte i en bestemt kontekst. Hun hevder, i tråd med det andre forskere har påpekt (Newman, 2001), at det er først når en forstår hvordan ideene fortolkes innenfor rammen av etablerte styringssystemer, at en kan få innsikt i hvorvidt og hvordan de bidrar til å endre praksis.

\section{En komparativ casestudie}

De empiriske eksemplene jeg viser til i dette kapitlet, er hentet fra et følgeforskningsprosjekt der prosessen med å iverksette hverdagsrehabilitering 
ble fulgt i to norske kommuner. Undersøkelsen ble designet som en komparativ casestudie. Fordelen med to eller flere ulike caser er at det blir mulig å peke på kontraster både innenfor en case og mellom caser, noe som igjen gir grunnlag for å utvikle forklaringer på hvordan fenomener henger sammen (Yin, 1994). Her baserte vi oss på casestudier fra to kommuner som begge var inspirert av ideen om hverdagsrehabilitering, men som i utgangspunktet var preget av ulike styringskontekster og styringskrav. Den ene (Sørkommunen) var organisert i tråd med en klassisk profesjonsbyråkratisk organisasjonsmodell (Mintzberg, 1985), der betydelig grad av makt og ansvar var delegert til ledere og koordinatorer som befant seg nær praksisnivået i organisasjonen. Den andre (Nordkommunen) hadde (ca. 15 år tidligere) latt seg inspirere av en bedriftsøkonomisk organisasjonsmodell. Denne modellen innebar at makt og ansvar i større grad var samlet i en sentral bestillerenhet - atskilt fra praksisnivået. En viktig grunn til at vi valgte oss kommuner med ulik styrings- og organisasjonsform, var nettopp at vi ønsket å få bedre innsikt i hvordan kontekstuelle forhold kunne tenkes å få betydning for hvordan ideen om hverdagsrehabilitering ble oversatt til praksis.

Prosjektet la opp til en formativ, dialogbasert prosessanalyse, der en viktig del av hensikten var å skape et «refleksjonsfelleskap» (Winther \& Munn-Giddings, 2001) og et «læringssamarbeid» (Gredig \& Sommerfeld, 2008) mellom forskere og utforsket. Det ble gjennomført intervjuer, samtaler og møter med personer som var involvert i referansegruppe/ styringsgruppe for hverdagsrehabilitering. Datainnsamlingen ble gjort på ulike tidspunkter gjennom den treårige prosjektperioden. Det ble blant annet arrangert tre fellessamlinger der begge kommunene deltok: et kickoff-seminar, et midtveisseminar og et avsluttende møte for planlegging av en formidlingskonferanse. I tillegg ble det gjennomført individuelle intervjuer med terapeuter og annet personell som arbeidet med hverdagsrehabilitering, samt tolv gruppesamtaler med pleiepersonale fra hjemmetjenesten og andre tilstøtende tjenester. Sammen med plandokumenter, interne evalueringer og ulike former for informasjonsmateriell gav dette oss et godt innblikk i vurderinger og begrunnelser som dannet utgangspunkt for kommunenes ulike veivalg, inkludert veivalg som berørte det tverrprofesjonelle samarbeidet. 
Forskningsdesignet la til rette for kommunikativ validering (Kvale, 1990). Forskernes beskrivelser og analyser av implementeringsprosessen ble prøvd ut og diskutert med ledere og ansatte i de to kommunene - både underveis i prosjektet og i sluttfasen, da utkast til rapport forelå (Vabø \& Vik, 2017).

\section{Systemoptimering med utgangspunkt i ulike styringsmodeller}

Hverdagsrehabilitering (HVR heretter) er et tjenestetilbud som i løpet av kort tid har fått stor oppslutning i nordiske kommuner. I beskrivelser av den populære tjenesten går det igjen at det dreier seg om en tidsavgrenset, intensiv og målrettet rehabiliteringsprosess som foregår i hjem og nærmiljø, og som tar utgangspunkt i aktivitetsmål som er viktige for personen selv. Ofte blir det understreket at det dreier seg om «tidlig innsats» for å forhindre at mennesker som nylig har opplevd et akutt funksjonsfall, blir svekket eller passivisert. Og det understrekes at tilnærmingen skal være tverrfaglig (Førland og Skumsnes, 2016; Tuntland \& Ness, 2014). Til tross for at ideen har fått stor oppslutning, gir den rom for mange fortolkninger - for eksempel omkring hvem som er målgruppen for tjenesten, hva som menes med at intervensjonen er tidsavgrenset og intensiv (hvor lenge, hvor ofte), hva som menes med tidlig innsats (hvor tidlig), eller hva en tverrfaglig tilnærming innebærer.

Når det gjelder tverrfaglig tilnærming (som det skal handle om i dette kapitlet), er det teoretisk mulig å tenke seg at en sammenkobling av ulike fagkunnskaper kan skje på ulike måter og i ulike stadier av tjenesteforløpet. I den norske faglitteraturen om hverdagsrehabilitering blir det gjerne understreket at det dreier seg om en form for tverrprofesjonelt samarbeid basert på tette, forpliktende relasjoner. Fagfolk fra ulike disipliner forutsettes å utvikle felles tverrfaglig kunnskap med utgangspunkt i brukerens mål, samtidig som de utnytter den særlige kunnskapen som de enkelte fagfolkene besitter (Tuntland \& Ness, 2014; Moe \& Brataas, 2016). Ikke desto mindre er det relevant å stille spørsmål om hvordan profesjonenes idealer om et samarbeid på tvers av ulike disipliner oversettes til praksis. 
Ved oppstarten av prosjektet i Sørkommunen og Nordkommunen opplevde vi at aktører som sto ansvarlige for iverksettingen, snakket om HVR i generelle og positive vendinger. De anså HVR som en tjeneste som, gjennom å understøtte de eldres egne ressurser, ville bidra til en mer kostnadseffektiv og bærekraftig tjeneste. Etter hvert som ideen materialiserte seg i praksis, ble det imidlertid gradvis tydeligere at de to kommunene foretok ganske ulike veivalg. Begrunnelsene for veivalgene var preget av praksiser og diskurser (talemåter) som var relatert til kommunenes ulike styringsmodeller.

\section{Sørkommunen: HVR - en spydspiss i et interorganisatorisk samarbeid om tidlig innsats}

I Sørkommunen, der tjenesteapparatet var organisert i tråd med en klassisk velferdsbyråkratisk modell, var det nylig erkjent at kommunen burde tenke mer langsiktig og satse mer på forebygging. Viktige kilder til omstillingsambisjonene var den tidligere nevnte Hagen-rapporten - Innovasjon i omsorg 2011:11 - samt en studietur til Fredericia i Danmark, der Sørkommunens representanter hadde fått høre om hvordan HVR med sin vekt på «tidlig innsats» og intensiv trening hadde klart å redusere omfanget av kostnadskrevende hjemmehjelp. Ledelsen festet lit til at HVR, til tross for å være en kostbar tjeneste, ville lønne seg på sikt - fordi den ville redusere behovet for langvarig hjelp. Ut fra denne langsiktige investeringstenkningen gav det mening å ta utgangspunkt i at tjenesten skulle være et tilbud til personer som viste typiske typiske tegn på å bli gradvis avhengig av hjelp, men som fortsatt hadde en viss restkapasitet og et potensial for å bli selvhjulpne.

Sørkommunen etablerte et selvstendig tverrfaglig team for hverdagsrehabilitering, «HVR-teamet», bestånde av en fysioterapeut, en ergoterapeut, en sykepleier og etter hvert en helsefagarbeider. Teamet skulle ideelt sett fungere som en spydspiss i en omstilling der hele tjenesteapparat $\mathrm{i}$ kommunen skulle gjøres mer proaktivt og forebyggende. Tanken var at fagfolk i alle tjenestene skulle utvikle en årvåkenhet for å fange opp personer som sto i fare for å rammes av et funksjonsfall - med påfølgende hjelpeavhengighet. En viktig begrunnelse for å organisere tjenesten i et 
selvstendig team var at det var ønskelig å utvikle spisskompetanse i grenseoppgangene mellom ulike fagfelt. Dersom HVR ble integrert som en del av den ordinære hjemmetjenesten, så man en fare for at fagutviklingen ville bli nedtonet, og at særlig sykepleierens kompetanse ville bli absorbert i annet, mer akutt helsearbeid.

Et interessant trekk ved Sørkommunens strategi var at den, gjennom å tilskrive HVR-teamet en rolle som spydspiss, bygde på et systemoptimeringsrasjonale som var i tråd med NPG og en interorganisatorisk tenkning. Kommunalsjefen understreket at arbeidet med å spore opp personer med et rehabiliteringspotensial ideelt sett skulle være et samarbeid på tvers av alle tjenestene $i$ kommunen. For å få denne tenkningen inn under huden ble det etablert en ressursgruppe bestående av representanter fra fire soner av hjemmetjenesten, fra en korttidsavdeling (som mottok ferdigbehandlede pasienter fra sykehus), fra en mestringsenhet for hjemmeboende med psykiske plager og fra dagsenteret der hjemmeboende eldre fikk ekstra tilsyn og sosialt samvær. Ressurspersonene skulle holde seg faglig oppdatert om HVR, og de skulle hver for seg sørge for at egen tjenesteenhet hadde rutiner og oppmerksomhet rettet mot å identifisere aktuelle kandidater for HVR. Ressurspersoner fra hjemmetjenesten skulle også ha et særlig ansvar for oppfølgingen av pasienter som til tross for gjennomført HVR-forløp ville ha behov for visse tjenester.

Lederen for HVR-teamet fungerte som pådriver og katalysator for å finne kandidater. Hun inviterte seg selv til rapportmøter, utskrivingsmøter og informasjonsmøter i andre tjenesteenheter. Det viktige spørsmålet omkring hvem som har potensial for å få utbytte av hverdagsrehabilitering, involverte dermed et bredt spekter av fagfolk: fastleger, terapeuter fra andre rehabiliteringstjenester, miljøarbeidere fra psykiatri samt personale fra hjemmesykepleie og dagsenter. Fagfolkene ble oppfordret til ikke å være for defensive med å henvise kandidater. HVR-lederens motto var følgende:

Det er bedre å henvise for mange enn for få. At noen kandidater blir avvist, er «naturlig» når det dreier seg om mennesker som befinner seg i gråsonen mellom å være hjelpeavhengig og selvstendig.

Et viktig tilleggsargument bak mottoet var at mange henvisninger samtidig ville være en kilde til læring og faglig utvikling (mer om dette 
nedenfor). På denne måten senket de terskelen for å få henvist kandidater som kunne ha et potensial for å gjenvinne eller bedre sin funksjonsevne. Dette medførte igjen at relativt mange mennesker fikk tilbud om HVR, samtidig som det også var relativt mange som ble avvist etter en nærmere kartlegging.

\section{Nordkommunen: HVR som en ny aktiverende arbeidsform i hjemmetjenesten}

Nordkommunen hadde, i likhet med mange andre norske kommuner, en delt forvaltningsstruktur der ansvaret for å vurdere behov og tildele tjenester var lagt til en sentral bestillerenhet - atskilt fra den operative tjenesten. En viktig del av hensikten med bestiller-utfører-strukturen var å sørge for bedre ressursstyring. På det tidspunktet HVR ble iverksatt, var helse- og omsorgstjenestene inne i en innsparingsprosess, der saksbehandlere ved bestillerenheten skulle være særlig påpasselige med å holde seg strengt innenfor rammen av sitt lovpålagte ansvar. KOSTRA-tall fra kommunen hadde indikert at ressurser i for stor grad var blitt tildelt personer med moderate hjelpebehov. Det ble forventet at saksbehandlere skulle bidra til å få tallet ned gjennom å prioritere de pasientene som hadde størst behov.

Prosjektgruppen som hadde ansvaret for iverksettingen av HVR, forklarte at de kortsiktige innsparingskravene også la klare begrensinger på hvor mange og hvem som kunne få vedtak om HVR, og hvor store faglige ressurser de kunne anvende på tjenesten. Det ble umulig å tenke seg at de skulle bedrive aktiv oppsporing av kandidater som kunne tenkes å ha nytte av et rehabiliteringsforløp på et tidlig stadium i et funksjonsfall. HVR skulle, på linje med ordinære hjemmetjenester, forbeholdes personer som etter kriterier i loven hadde behov for «nødvendig helsehjelp». Det viste seg etter hvert at Nordkommunen tilbød HVR til relativt få personer - kun en fjerdedel av det antallet som mottok tjenesten i Sørkommunen, (jf. Vabø \& Vik, 2017, s. 44).

Innenfor disse økonomiske og administrative rammene gav det mening for prosjektgruppen for HVR-satsingen å forstå den nye tjenesten som en endret arbeidsform $i$ hjemmetjenesten. Hensikten var ikke primært å 
tilby HVR som en forebyggende tjeneste, men å bidra til at arbeidet i den ordinære hjemmetjenesten var mer orientert mot å understøtte brukernes egne ressurser. Dette var en ny måte å jobbe på som utnyttet fysio- og ergoterapeutenes rehabiliteringskompetanse, og som derigjennom gjorde tjenestene mer treffsikre og kostnadseffektive. Ut fra denne forståelsen mente styringsgruppen at det var mest fornuftig å velge en integrert modell. To terapeuter ble ansatt i hjemmetjenesten i hver sin halve stilling, samtidig som de beholdt en halv stilling og arbeidsplasstilhørighet i kommunens fysio- og ergotjeneste. Terapeutene hadde ansvaret for kartlegging og utarbeidelse av rehabiliteringsplan, men delegerte det praktiske rehabiliteringsarbeidet til det ordinære pleiepersonalet. Underveis i prosjektet ble det understreket at dette bidro til en smartere måte å jobbe på i hjemmetjenesten. Pleiepersonalet fortalte at de lærte små knep og triks som bidro til at brukerne ble selvhjulpne med oppgaver som hjemmetjenesten tidligere hadde brukt mye tid på. Som en av de ansatte sa:

Vi er kvitt en hel del tulleoppgaver - oppgaver vi tidligere brukte mye tid på. For eksempel det å gå inn og ut til folk for å hjelpe dem av og på med støttestrømper. Nå har vi strømpepåtrekkere.

Fortellinger om hvordan hjemmetjenesten i noen tilfeller hadde lyktes med å «delegere» oppgaver til brukeren selv, ble presentert som suksesshistorier i dobbelt forstand: Den nye måten å jobbe på hadde ført til at brukerne fikk bedre kontroll over eget liv, samtidig som den hadde bidratt til å redusere pleiernes tidsbruk. Dette var helt i tråd med den kortsiktige effektiviseringsstrategien kommunen hadde sporet inn på.

\section{Samme tverrfaglige tjenestetilbud - to ulike former for tverrprofesjonelt samarbeid}

HVR blir ofte omtalt som en tjenesteform som er relativt likeartet på tvers av kommunegrenser. ${ }^{2}$ I forskningslitteraturen blir det likevel påpekt at

2 Dette lå blant annet implisitt i den nasjonale effektstudien som ble utført på oppdrag for Helsedirektoratet, der effekter av 833 HVR-intervensjoner ble målt og sammenlignet med ordinære hjemmetjenester på tvers av 43 kommuner (Langeland mfl., 2016, s. 4). 
det er uklart, ikke bare hvilke pasientgrupper som blir antatt å være relevante kandidater for HVR, men også hva slags intervensjon HVR dreier seg om (Legg, Gladman, Drummond \& Davidson, 2016). I Norge synes det å være bred enighet om at HVR dreier seg om et tverrprofesjonelt samarbeid «der terapeuter, sykepleiere og ansatte i hjemmetjenesten i kommunen samarbeider og bistår personen med trening og tilrettelegging av hverdagsaktiviteter som er viktige for personen selv» (Førland \& Skumsnes, 2016, s. 11). Denne vide definisjonen ble anvendt i begge våre kommuner. Imidlertid avdekket undersøkelsen vår at det tverrprofesjonelle samarbeidet omkring HVR-pasientene ble utviklet på helt forskjellige måter.

\section{Sørkommunen - et integrert teamarbeid}

I Sørkommunen, der HVR-tjenesten var organisert som et team - «et hold» (Højholdt, 2016), var tanken at de spesifikke fagkunnskapene hos sykepleier, ergo- og fysioterapeut skulle utnyttes når det gjaldt kartlegging, operativt rehabiliteringsarbeid og evaluering/plan for videre oppfølging. Medlemmene av teamet beskrev samarbeidet som fleksibelt. Hvorvidt det var en sykepleier, fysio- eller ergoterapeut som tok hovedansvaret for å kartlegge pasientens situasjon og funksjonsevne, kom helt an på hva slags funksjonsnedsettelser det dreide seg om. Dersom en rekke medisinske problemstillinger var involvert, var sykepleierens monofaglige kompetanse påkrevd, og dersom det gjaldt opptrening etter en bruddskade, var fysioterapeutens kompetanse påkrevd. Ettersom teamet jobbet under samme tak til daglig, diskuterte de kontinuerlig hvilke erfaringer de fikk i møte med ulike pasienter, og utvekslet kunnskap med hverandre. For eksempel ville ergoterapeuten spørre om bistand fra sykepleieren dersom hun opplevde at pasienten klaget over smerter eller svimmelhet. Sykepleieren forklarte at hun aldri ville finne på å endre et treningsprogram som fysioterapeuten hadde foreslått, men ville be fysioterapeuten om å vurdere en endring dersom hun opplevde at treningsprogrammet ble for krevende for pasienten. De hadde som en tommelfingerregel at alle fagfolkene skulle ha vært innom hver pasient i løpet av den første uken. 
Målet var også å lære av hverandre - og derigjennom utvikle noen arbeidsformer som var felles for alle deltakerne i teamet. Som eksempel nevnte fysioterapeuten at hun, etter å ha samarbeidet med sykepleieren, hadde lært å spørre om søvn, ernæring og væskeinntak. Tilsvarende lærte sykepleieren å utføre de enkleste treningsøvelsene fra fysioterapeuten og de mest elementære støttetiltakene fra ergoterapeuten.

Da teamet var nyopprettet, hadde det en fast praksis med å la to fagfolk gå sammen på kartleggingsbesøk. Dette ble dels gjort fordi teamet ønsket å utvikle et felles tilpasset kartleggingsverktøy som var flerdimensjonalt og egnet til å mobilisere alle fagkunnskaper temaet hadde, dels fordi det ønsket å justere og avklare hva som måtte til for at brukerne kunne nå sine mål (jf. Vabø \& Vik, 2017, kap. 4). Etter hvert som medlemmene av teamet ble trygge på kartleggingsprosedyrene, avviklet de rutinen med å gå to og to. De fant også ut at det var hensiktsmessig å ansette en helsefagarbeider som kunne fungere som «hjemmetrener» og avlaste i det rent operative rehabiliteringsarbeidet. De ulike fagfolkene var likevel kontinuerlig involvert i alle delene av rehabiliteringsforløpene, og hadde hovedansvar for å evaluere og utarbeide en videre plan for pasienter som skulle overføres til hjemmetjenesten med noe hjelp.

\section{Nordkommunen: Et sekvensielt stafettløp}

I Nordkommunen hadde organiseringen av HVR i større grad karakter av å være et «stafettløp» (en overlevering, jf. Højholdt, 2016). Det var i utgangspunktet bestillerenheten som hadde ansvaret for å ta den endelige beslutningen om hvem som var egnede kandidater. Selv om fagfolk i hjemmetjenesten kunne foreslå kandidater, var de klart underordnet vurderingen fra bestillerenheten. I neste etappe hadde de to deltidsansatte terapeutene et hovedansvar for å kartlegge pasientens situasjon samt utarbeide en plan. Ansvaret for å utføre det operative rehabiliteringsarbeidet i tråd med planen, ble så overlatt til det ordinære personalet i hjemmetjenesten. Terapeutene tok siste etappe med avsluttende evaluering og anbefalt oppfølging.

Ifølge en av terapeutene innebar modellen at de måtte lage planer og rehabiliteringsopplegg som var enkle nok til at «alle» kunne utføre det. 
Hun mente at rehabiliteringsarbeidet dermed fikk et noe mer standardisert preg enn det ville ha fătt dersom tjenesten hadde blitt utført av dem selv innenfor et profesjonelt team. Hjemmetjenestens personale fortalte at de hadde begrenset med tid til rådighet. Ettersom vedtak fra bestillerkontoret var preget av at tjenesteomfanget skulle begrenses, ble normen at rehabiliteringsarbeidet skulle holdes innenfor de samme tidsrammene som de ordinære pleieoppgavene. Dermed var det begrenset med fleksibilitet til å justere innsatsen utover de standardiserte oppleggene som i utgangspunktet var fastsatt av terapeutene.

\section{Tverrprofesjonell samarbeidslæring eller kompetansedelegasjon?}

Det var et uttrykt mål i begge kommunene at HVR generelt skulle inspirere og bidra til kompetanseutvikling i de hjemmebaserte tjenestene. Det skulle bli et tankesett og en arbeidsform som skulle internaliseres og praktiseres også i det ordinære arbeidet i hjemmetjenesten. Begge kommunene hadde lagt opp til at ansatte i hjemmetjenesten fikk faglige opplæringsdager om HVR, og de var opptatt av at nye samarbeidsflater på tvers av faggrupper skulle utnyttes til mer situert læring - læring på arbeidsplassen.

Til tross for at kommunenes mål og visjoner var like også på dette punktet, viste det seg at både betingelsene for og formen for situert læring ble forskjellig i praksis. Forskjellene handlet dels om at kommunene fikk ulik erfaringsmengde som følge av ulikt antall HVR-løp; dels om at de opererte med ulike læringsbegreper.

\section{Sørkommunen: Gjensidig læring}

I Sørkommunen førte det aktive arbeidet med å spore opp kandidater til at det ble skapt flere læringsarenaer i grenseflatene mellom HVR-teamet og de øvrige kommunale tjenestene. HVR-teamet deltok på nettverksmøter omkring pasienter som ble skrevet ut fra kommunens korttidsavdeling, og det deltok jevnlig på hjemmetjenestens møter der status for 
ulike pasienter ble gjennomgått. Mange diskusjoner om egnethet, kartleggingssamtaler omkring ulike kategorier av pasienter og stadig flere gjennomførte rehabiliteringsforløp bidro til økt erfaringskunnskap både i HVR-teamet og i hjemmetjenesten.

En viktig kilde til læring var en intern hospiteringsordning som først ble tilrettelagt for at ressurspersoner (fra de ulike tjenesteenhetene) skulle få et konkret innblikk i hvordan HVR-teamet jobbet. Hospitering i HVRteamet ble etter hvert en obligatorisk del av opplæringen for alle nyansatte i hjemmetjenesten, og det ble et generelt tilbud til andre interesserte (fra hjemmetjenesten, mestringsteamet, rehabiliteringsavdelingen og dagsenteret). Tanken var at alle skulle lære seg «den nye måten å jobbe på». Gjennom faglige diskusjoner som oppsto i grenseflatene mellom HVRteamet og hjemmetjenesten, ble det også bestemt at hospiteringsordningen skulle «snus på hodet», slik at terapeutene fra HVR-teamet fikk et mer erfaringsnært innblikk i hjemmetjenestens hverdag. Tanken var at de skulle få se konkrete eksempler på hva slags pasienter pleierne anså for å være «lite egnede» eller «kanskje egnede» for HVR. Terapeutene skulle også få et bedre innblikk i hvordan tidspresset i hjemmetjenesten påvirket muligheten for å følge opp planer fra HVR-teamet. Læringsprosessene og læringsutbyttet i Sørkommunen ble dermed i stor grad beskrevet som gjensidige prosesser, der HVR-teamet og hjemmetjenestens personale skulle lære av og om hverandre.

Det gjensidige læringsperspektivet kom også tydelig til uttrykk i beskrivelser av læringen innad i HVR-teamet. Terapeutene understreket hvor viktig det var at sykepleieren var en del av teamet og ikke bare en «ekstern» samarbeidspartner (slik de hadde hørt om i andre kommuner). De opplevde det betryggende å ha en som kunne «se» når det er nødvendig å ta kontakt med lege, og som kunne stille kritiske spørsmål til deres terapeutiske vurderinger. Som eksempel på hvordan hun hadde fått styrket sin egen faglighet og evne til å agere kvalifisert, fortalte fysioterapeuten om hvordan hun nå var blitt mer bevisst på smerteproblematikk - for eksempel at det kunne være aktuelt at pasienten tok smertestillende før trening, men at en måtte være oppmerksom på at for mye kunne medføre forstoppelse. 


\section{Nordkommunen: Formidlingslæring}

I Nordkommunen var en viktig del av tanken bak det å integrere HVR i hjemmetjenesten at dette ville inspirere personalet til en rehabiliterende arbeidsform, også overfor pasienter som ikke fikk innvilget et fullstendig HVR-forløp. Læring og fagutvikling var med andre ord en vesentlig del av hensikten med å velge en integrert form. Personalet skulle dessuten få faglig påfyll - dels gjennom et kort hospiteringsopphold i en dansk kommune, dels gjennom ukentlige lunsjmøter sammen med terapeutene. Den opprinnelige planen for lunsjmøtene var at de skulle veksle mellom refleksjoner omkring bestemte forhåndsdefinerte temaer knyttet til HVR og refleksjoner omkring erfaringer med konkrete HVR-forløp. Med et relativt lavt antall kandidater for HVR ble møtene imidlertid gjerne for teoretiske. Personalet ønsket seg mer praktisk opplæring. Dermed ble lunsjmøtet omdefinert til et ukentlig fagmøte som i bredere forstand handlet om hvordan HVR-tankegangen kunne smitte over på det ordinære arbeidet. I disse møtene opptrådte terapeutene som kunnskapsformidlere som gav tips, råd og små leksjoner, samtidig som de oppfordret de ansatte i hjemmetjenesten til å stille spørsmål og ta opp konkrete utfordringer de hadde støtt på i hverdagen, når de forsøkte å bistå pasienter med å være mest mulig selvhjulpne.

Både samarbeidet med terapeutene og lunsjmøtene ble høyt verdsatt av personalet i hjemmetjenesten. Terapeutene hadde gitt dem faglig påfyll i form av nye arbeidsverktøy som satte dem i stand til å understøtte brukernes mestringsevne. Vi hørte imidlertid ikke om tilsvarende læringsutbytte fra terapeutenes side. Beskrivelsene av dem som instruktører og møteledere (i lunsjmøtene) vitnet om en tradisjonell enveisoverføring av fagkunnskap fra terapeutene (lærerne) til pleiepersonalet (elevene). Det var underforstått at det først og fremst var terapeutenes faglighet som ble ansett for å være relevant kunnskap for å utvikle den nye arbeidsformen.

\section{Oppsummering og diskusjon}

I et presset helsevesen - der knapphet på fagutdannet personell merkes tydelig, og der komplekse helseproblemer står i kø -, er det blitt en nesten udiskutabel sannhet at fagfolk fra ulike disipliner bør samarbeide mer. 
Ideer om tverrprofesjonelt samarbeid skaper håp om bedre ressursutnyttelse og mer kvalifiserte og innovative løsninger. I pedagogiske tekster er det ofte underforstått at et tverrprofesjonelt samarbeid er noe som vil lykkes dersom fagfolk tilegner seg tverrprofesjonell samarbeidskompetanse (Kvilhaugsvik \& Husøy, 2017; Almås, Vasset, \& Ødegård, 2018). Denne typen tekster synes å overse det faktum at samarbeidet mellom ulike profesjonsutøvere utspiller seg i institusjonelle settinger preget av bestemte maktstrukturer og motstridende krav (Paradis \& Whitehead, 2015).

I dette kapitlet har jeg - med utgangspunkt i casestudier fra to kommuner - vist hvordan kommunenes ulike styringsambisjoner og styringssystemer spiller en viktig rolle når ideen om et tverrprofesjonelt samarbeid skal fylles med et konkret meningsinnhold. De to kommunene som ble undersøkt, var inspirert av samme idé om hverdagsrehabilitering (HVR), og de var enige om at det dreide seg om en form for tverrfaglig rehabilitering der fagfolk samarbeider om å bistå pasienter som hadde hatt et funksjonsfall, med trening og tilrettelegging av hverdagsaktiviteter (Førland \& Skumsnes, 2016, s. 11). Til tross for den generelle enigheten landet de på løsninger som innebar at samarbeidet mellom fagfolk ble begrunnet forskjellig og fikk høyst forskjellig innhold, omfang og form.

I Sørkommunen (se figur 1) ble iverksetting av HVR vevet inn i kommunens ambisjon om å jobbe mer forebyggende. Innenfor rammen av en langsiktig investeringsstenkning gav det mening å legge opp til et samarbeid på tvers av tjenester og faggrupper for å spore opp kandidater som sto i fare for å få et funksjonsfall. Invitasjonen til ulike fagfolk om å spille inn forslag til hvilke konkrete personer som var aktuelle kandidater, bidro til at spørsmålet om egnethet for HVR ble belyst fra ulike faglige perspektiver. For øvrig ble både kartlegging, målformulering, praktisk utførelse og oppfølging av rehabiliteringsarbeidet noe som ble diskutert og løst i fellesskap i et team der sykepleier, ergo- og fysioterapeut samarbeidet tett. Det tverrprofesjonelle samarbeidet - både på tvers av tjenester og innad i teamet - ble forstått og beskrevet som et gjensidig lærings- og utviklingsarbeid. Man skulle lære om og av hverandre.

I Nordkommunen (se figur 2) var organiseringen av HVR-arbeidet i større grad preget av en kortsiktig innsparingspolitikk, noe som kom til uttrykk gjennom en strengere tildelingspraksis og en mer hierarkisk 
arbeidsdeling: Saksbehandlerne i bestillerenheten hadde ansvaret for å avgjøre hvem som skulle få tildelt HVR, terapeutene hadde hovedansvaret for å kartlegge funksjonsevne, identifisere mestringsmål, legge planer og evaluere resultater, mens ansvaret for det operative rehabiliteringsarbeidet ble delegert til det ordinære pleiepersonalet. Det dreide seg om en form for vertikal delegering (Nancarrow \& Borthwick, 2005), der pleiepersonalet fikk utvidet sitt oppgaverepertoar, samtidig som arbeidet var kontrollert av terapeutene.

Et stort nettverk av

fagfolk ble invitert

Integrert teamarbeid:

tíl å diskntere

fysio-, ergoterapiog

Helsefagarbeider bidrar

egnethet. HVR.

syleepleie samarbeider

intforelsen

teamet tíldeler.

om hele forlopet.

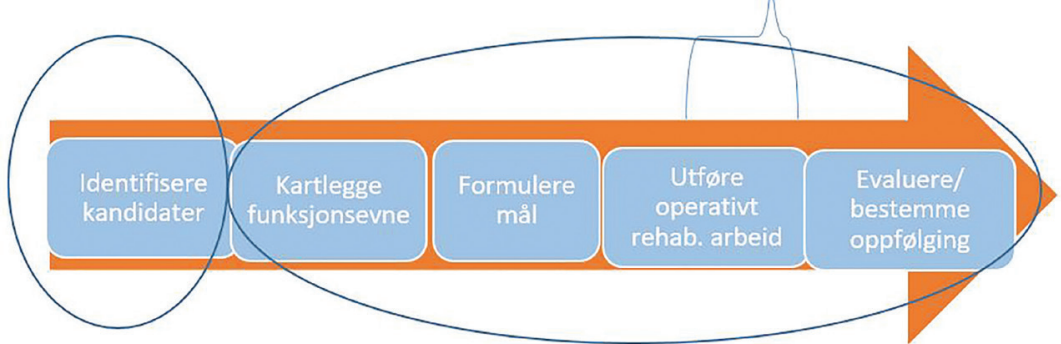

Figur 1. Sørkommunen: Samarbeid preget av gjensidig utveksling av fagkunnskap

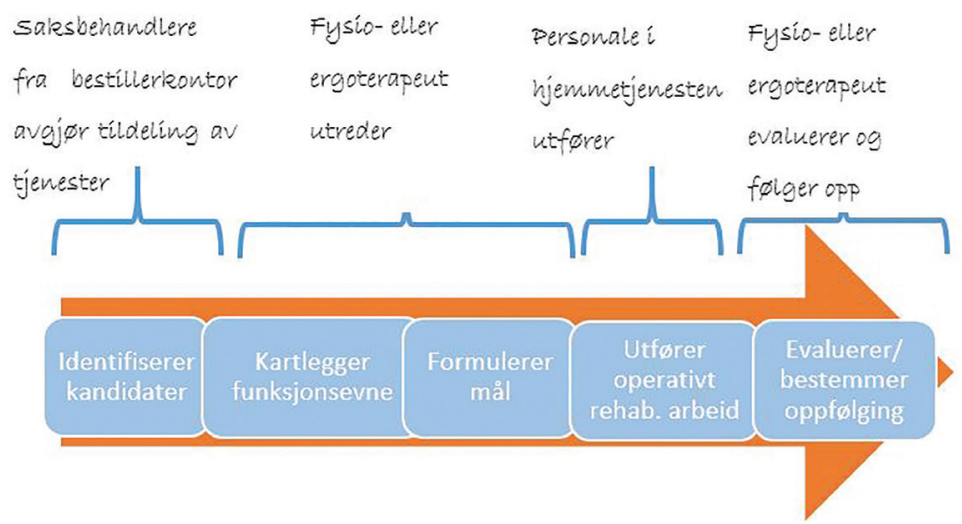

Figur 2. Nordkommunen: Samarbeid preget av «stafettløp» og hierarkisk arbeidsdeling 
Undersøkelsene fra de to kommunene viser hvordan forståelsen omkring det tverrprofesjonelle samarbeidet blir farget av styringsambisjoner og styringsstrukturer som omgir praksisfeltet. At det i Sørkommunen så tydelig ble lagt opp til at både tildeling og utførelse av HVR skulle skje i samarbeid mellom ulike faggrupper på det utøvende nivået, må sees i lys av at kommunen i utgangspunktet hadde tradisjon for å delegere ansvaret for behovsvurderinger til fagfolk. Idealet ble understøttet av kommunens strategiske satsing på forebygging og langsiktig tenkning. Det var simpelthen bruk for den informasjonen fagfolkene var i besittelse av i kraft av sin nærhet til brukerne. Fagfolkenes egen forståelse av hva det vil si å samarbeide på tvers av ulike disipliner, ble farget av de demokratiske samarbeidsidealene de brakte med seg fra lærebøker om tverrprofesjonell samarbeidslæring (Almås mfl., 2018; Moe \& Brataas, 2016; Tuntland \& Ness, 2014). Den interne hospiteringsordningen og det tverrprofesjonelle samarbeidet om å finne egnede kandidater for HVR, fungerte dermed som en «indre» (endogen) drivkraft i retning av en mer NPG-inspirert styringslogikk (se også Suddaby \& Viale, 2011; Temeer, 2009).

At Nordkommunen landet på en løsning som innebar et mer hierarkisk og sekvensielt samarbeid, må sees i lys av kommunens NPM-inspirerte styringssystem og tilhørende vektlegging på kortsiktige resultatmålinger. Her ble ideen om HVR som en form for «tidlig innsats» nedtonet, med henvisning til at kommunen primært ville satse på forebygging gjennom mer kollektive virkemidler - ikke gjennom å gi ressurskrevende tjenester til enkeltpersoner. Innenfor rammen av kommunens styringsstrategi var det mer meningsfullt å anse HVR som en særegen arbeidsform i hjemmetjenesten - en aktiverende arbeidsform som ville understøtte de eldres evne til selvhjulpenhet og samtidig bidra til kostnadsreduksjon for kommunen. Det gav også mening at knappe terapeutressurser skulle utnyttes bedre gjennom å bidra til at pleiepersonalet tilegnet seg nye metoder og teknikker for en aktiverende arbeidsform.

Beskrivelsene av de to kommunene må ikke leses som eksempler på hvordan tverrfaglig samarbeid blir determinert av ulike styringsmodeller. Norske kommuner er preget av komplekse endringsdynamikker der ulike styrings- og organisasjonsformer stadig brytes mot hverandre 
(Vabø, 2014). Det er ikke gitt at alle kommuner som har holdt fast på en tradisjonell profesjonsbyråkratisk modell, vil handle så proaktivt som det ble gjort i Sørkommunen. Grepene som ble tatt, var dels et resultat av at ledelsen delte Hagen-utvalgets anbefalinger om en langsiktig forebyggende strategi, dels et resultat av HVR-lederens offensive lederstil. Det er fullt mulig å tenke seg at andre ledere og fagfolk ville ha vært mer tilbøyelige til å tenke mer kortsiktig og mer monofaglig. Motsvarende er det mulig å tenke seg at andre typiske NPM-kommuner ville ha beveget seg i retning av en mer tillitsbasert styringsform - gjennom å redusere detaljstyring samt understøtte fagfolks egen kapasitet til å gjøre riktige vurderinger. En slik dreining ser vi konturene av gjennom såkalte tillitsreformer, som for tiden prøves ut i flere bydeler i hovedstaden (Eide, Gullslett, Nilsen, Dugstad \& Eide, 2018; Dyrhol, 2018; Vatn, 2018).

Beskrivelsene fra de to kommunene er heller ikke ment å gi en vurdering av hva som er en «riktig» form for tverrprofesjonelt samarbeid. Hensikten er snarere å vise hvor elastiske begreper om tverrfaglighet og tverrprofesjonalitet er, og at de kan tjene mange ulike hensikter og romme ulike former for samarbeid. Begrepene kan begrunnes med utgangspunkt i ulike systemrasjonaler: langsiktige og interorganisatoriske eller kortsiktige og intraorganisatoriske. De kan vise til samarbeidspraksiser som er basert på tillit og gjensidig læring så vel som praksiser basert på vertikal delegering og enveislæring. Å hevde at en tverrfaglig tilnærming i seg selv er noe selvinnlysende fordelaktig eller bra, blir dermed meningsløst. En må alltid reise spørsmål ved «hva slags hensikt» det har å samarbeide, og for hvem eller hva samarbeidet kan tenkes å være en fordel.

\section{Referanser}

Adler, P., Kwon, S.-W. \& Heckscher, C. (2019). Professional work: The emergence of collaborative community. Organization Science, 19(2), 359-37. https://doi. org/10.1287/orsc.1070.0293

Almås, S.H., Vasset, F. \& Ødegård, A. (Red.) (2018). Tverrprofesjonell samarbeidsloring (TPS). Oslo: Fagbokforlaget.

Barr, H. (2013). Towards a theoretical framework for Interprofessional education. Journal of Interprofessional Care, 27(1), 4-9. https://doi.org/10.3109/13561820.2012. 698328 
Burau, V., Carstensen, K., Lou, S. \& Kuhlmann (2017). Professional groups driving change toward patient-centered care: Interprofessional working in stroke rehabilitation in Denmark. BMC Health Service Research, 662. https://doi. org/10.1186/s12913-017-2603-7

Bergold, J. \& Thomas, S. (2012). Participatory research methods: A methodological approach in motion. Forum: Qualitative Social Research, 1. https://doi. org/10.17169/fqs-13.1.1801

Brandsen, T. \& Honingh, M. (2013). Professionals and shift in governance. International Journal of Public Administration, 36(12), 876-883.

D’Amour, D. \& Oandasan, I. (2005). Interprofessionality as the field of interprofessional practice and interprofessional education: An emerging concept. Journal of Interprofessional Care, 19 (Suppl. 1), 8-20. https://doi. org/10.1080/13561820500081604

Dyrhol, V.V. (2018). Oversetting, demping og filtrering av tillitsreformen i Oslo kommune. En studie i to sektorer (Masteroppgave i styring og ledelse), OsloMet storbyuniversitetet, Fakultet for samfunnsvitenskap. Oslo.

Eide, T., Gullslett, M.K., Nilsen, E.R., Dugstad, J. \& Eide, H. (2018). Tillitsmodellen hovedpilotering i Oslo kommune 2017-18. Skriftserien fra Universitetet i SørøstNorge, nr. 4/2018. Drammen: USN / Vitensenteret helse og teknologi.

Flynn, R. (1999). Managerialism, professionalism and quasi-markets. I M. Exworth \& S. Halford (Red.), Professionals and the new managerialism in the public sector (s. 18-36). Buckingham: Open University Press.

Førland, O. \& Skumsnes, R. (2016). Hverdagsrehabilitering. En oppsummering av kunnskap. Senter for omsorgsforskning, vest, Bergen. https://brage.bibsys.no/ xmlui/handle/11250/2414929

Gredig, D. \& Sommerfeld, P. (2008). New proposals for generating and exploiting solution-oriented knowledge. Research on Social Work Practice, 18(4), 292-300. https://doi.org/10.1177/1049731507302265

Helse- og omsorgsdepartementet. (2014). Fremtidens primorhelsetjeneste - noerhet og helhet (Meld. St. 26 (2014-2015)). Oslo: Helse- og omsorgsdepartementet.

Hudson, R. (2002). Interprofessionality in health and social care: The Achilles' heel of partnership? Journal of Interprofessional Care, 16(1), 7-17. https:// doi:10.1080/13561820220104122

Højholdt, A. (2016). Tveerprofessionelt samarbejde i teori og praksis (2. utg). København: Hans Reitzels forlag.

Kamp, A. \& Hvid, H. (2012). Introduction: Elderly care in transition. I A. Kamp \& $\mathrm{H}$. Hvid (Red.), Elderly care in transition - management, meaning and identity at Work. A Scandinavian perspective (s. 13-28). København: Copenhagen Business School Press. 
Kobro, L.U. (Red.) (2018). La oss gjøre det sammen! Håndbok i lokal samskapende sosial innovasjon. Høgskolen i Sørøst-Norge / Senter for sosialt entreprenørskap og samskapende sosial innovasjon.

Koppenjan, J. (2012). The new public governance in public service delivery. Reconciling efficiency and quality, The Hague: Eleven International Publishing.

Kvale, S. (1990). Det kvalitative interview. I I Andersen (Red.), Valg af organisationssosiologiske metoder: et kombinationsperspektiv. (s 215-241)

København: Samfundslitteratur.

Kunnskapsdepartementet. (2011). Utdanning for velferd. (Meld. St. 13 (2011-2012)). Oslo: Kunnskapsdepartementet.

Langeland, E., Førland, O., Aas, E., Birkeland, A. Folkestad, B., Kjeken, I., Jacobsen F.F. \& Tuntland, H. (2016). Modeller for hverdagserehabiliteing, en følgeevaluering i norske kommuner. Effekter for brukere og gevinster for kommunene? (Rapport 6/2016). Senter for omsorgsforskning, vest, Bergen.

Legg, L., Gladman, J., Drummond, A. \& Davidson, A. (2016). A systematic review of the evidence on home care reablement services. Clinical Rehabilitation, 3o(8), 741-749. https://doi.org/10.1177/0269215515603220

Lehn-Cristiansen S. (2016). Tvorprofessionelt samarbejde i sundhedsfaglig praksis. København: Munksgaard.

Minzberg, H. (1983). Structure in fives: Designing effective organizations. Englewood Cliffs: Prentice-Hall.

Moe, A. \& Brataas, H.V. (2016). Interdisciplinary collaboration experiences in creating an everyday rehabilitation model: A pilot study. Journal of Multiprofessional Healthcare, 9, 173-182. https://doi.org/10.2147/JMDH.S103696

Nancarrow, S. \& Borthwick, A.M. (2005). Dynamic professional boundaries in the healthcare workforce. Sociology og Health and Illness, 27(7), 897-919. https://doi. org/10.1111/j.1467-9566.2005.00463.x

Newman, J. (2001). Modernizing governance. New labour, policy and society. London: Sage.

Newman, J., Barnes, M., Sullivan H. \& Knops, A. (2004). Public participation and collaborative governance. Journal of Social Policy, 33(2), 203-223. https://doi. org/10.1017/Soo47279403007499

Noordegraaf, M. (2011). Risky business: How professional and professional fields (must) deal with organizational issues. Organization Studies, 32(10), 1349-1371. https://doi.org/10.1177/0170840611416748

Osborne, S. (2006). Editorial: The New Public Governance? Public Management Review, 8(3), 377-387. https://doi:10.1080/14719030600853022

Nygård, L. (1984). Korleis bør kommunane organisere omsorgstenesta si? Rapport 4/84. Trondheim: Norsk institutt for sykehusforskning. 
Paradis E. \& Whitehead, C.R. (2015). Louder than words: Power and conflict in interprofessional education articles, 1954-2013. Medical Education, 49(4), 399407. https://doi.org/10.1111/medu.12668

Suddaby, R. \& Viale, T. (2011). Professionals and field-level change: Institutional work and the professional project. Current Sociology, 59(4), 423-442. https://doi. org/10.1177/0011392111402586

Termeer, C.J.A.M. (2009). Barriers to new modes of horizontal governance. Public Management Review, 11(3), 299-316. https://doi.org/10.1080/14719030902798180

Torfing, J., Sørensen, E. \& Røiseland, A. (2016). Transforming the public sector into an arena for co-creation: Drivers, barriers and ways forward. Administration and Society. https://doi.org/10.1177/0095399716680057

Torfing, J. \& Triantrafillou, P. (2016). What's in a name? Grasping new public governance as a political-administrative system. International Review of Public Administration, 18(2), 9-25. https://doi.org/10.1080/12294659.2013.10805250

Tuntland, H. \& Ness, N.E. (Red.). (2014). Hverdagsrehabilitering. Oslo: Gyldendal Akademisk.

Vabø, M. (2015). Changing welfare institutions as sites of contestation. I F. Engelstad \& A. Hagelund (Red.), Cooperation and conflict the Nordic way. Work welfare and institutional change in Scandinavia (s. 252-261). Berlin: de Gruyter Open.

Vabø, M. (2014). Dilemmaer i velferdens organisering. I M. Vabø \& S.I. Vabo (Red.), Velferdens organisering (s. 11-78). Oslo: Universitetsforlaget.

Vabø, M. (2007). Organisering for velferd. Hjemmetjenesten i en styringsideologisk brytningstid. Avhandling for dr.philos.-graden (NOVA rapport 22/2007). Oslo: Det samfunnsvitenskapelige fakultet, Universitet i Oslo.

Vabø, M. \& Vik, K. (2017). Sammen om en aktiv hverdag. Hverdagsrehabilitering $i$ Eigersund og Karmøy kommune - erfaringer og refleksjoner fra et forskningssamarbeid (NOVA rapport 17/2017). Hentet fra: http://www.hioa.no/ Om-OsloMet/Senter-for-velferds-og-arbeidslivsforskning/NOVA/Publikasjonar/ Rapporter/2017/Sammen-om-en-aktiv-hverdag.

Vatn, G. (2018). Troen på tillitsreformen - en studie av sentrale aktørers forståelse av Tillitsreformen i Oslo kommune (Masteroppgave i styring og ledelse). OsloMet storbyuniversitetet, Fakultet for samfunnsvitenskap. Oslo.

Weber, K.E. \& Glynn, M.A. (2006). Making sense with institutions: Context, thought and action in Karl Weick's theory. Organization Studies, 27(11), 1639166o. https://doi.org/10.1177/0170840606068343

Weick, K.E. (1995). Sensemaking in organizations. Thousand Oaks: Sage.

WHO (2010). Framework for action on interprofessional education and collaborative practice. Geneva: https://www.who.int/hrh/resources/framework_action/en/ 
WHO (2016). Framework on integrated, people-centred health services, A69/39 Report by the Secretariat http://apps.who.int/gb/ebwha/pdf_files/WHA69/A69_39-en. pdf?ua $=1 \& u a=1$

Winter, R. \& Munn-Giddings, C. (Red.) (2001). A handbook for action research in health and social care. London: Routledge.

Yin, R. (1994). Case study research: Design and methods (2. utg.). Thousand Oaks, CA: Sage Publishing. 


\section{Tverrfaglige team - hvordan lykkes?}

Helge Ramsdal

Avdeling for helse og velferd, Høgskolen i Østfold

Sammendrag: I dette kapittelet gjennomgås noen perspektiver på teamorganisering i helse- og velferdssektoren. Spørsmålet er hvordan team kan bli effektive når det gjelder mål og oppgaver. Med utgangspunkt i en analysemodell der ulike aspekter ved teamorganisering blir sett i sammenheng, drøfter jeg tre empiriske studier som belyser forhold som hemmer og fremmer effektivt arbeid i team. Denne drøftingen er basert på studier av tverrfaglige team fra henholdsvis arbeids- og velferdsetaten, lokalbaserte tjenester for mennesker med rusproblemer og psykiske lidelser, og et overvektsteam ved et sykehus. Innenfor rammen av den analysemodellen som er presentert, er det to forhold som fremheves som avgjørende for om teamene har lykkes i sine intensjoner: For det første kontekst, det vil si kjennetegn ved de delene av helse- og velferdssektoren teamene arbeider innenfor. Hvordan team kan inngå i det tjenestesystemet de er en del av, har stor betydning. For det andre er også teammedlemmenes tilknytningsform som heltids- eller deltidsdeltakere i teamet viktig. Vi ser på betydningen av å foreta en kritisk vurdering av den sammenhengen etableringen av nye team inngår i, og at en er bevisst på ulike utfordringer som vil kunne møte teamene - avhengig av hvilke organisatoriske løsninger en velger.

Nøkkelord: tverrfaglige team, helse- og velferdspolitikk, kontekstuell analyse

\section{Innledning}

Regjeringen vil legge til rette for en mer teambasert helse- og omsorgstjeneste, og sier «at tjenestene er for fragmenterte, bl.a. som følge av siloorganisering».

(Stortingets arbeids- og sosialkomité, 2016)

Opprettelse av tverrfaglige team er en vanlig metode for å organisere arbeid som skal løse komplekse problemer i helse- og velferdssektoren.

Sitering av dette kapitlet: Ramsdal, H. (2019). Tverrfaglige team - hvordan lykkes?. I C. Bjørkquist \& M. Jerndahl Fineide (Red.), Organisasjonsperspektiv på samordning av helse- og velferdstjenester (s. 95-117). Oslo: Cappelen Damm Akademisk. https://doi.org/10.23865/noasp.66.ch4.

Lisens: CC BY 4.0 
Slike team er ofte omspunnet av idealistiske ideer som at «Nobody is perfect, but a team can be!» (Belbin, 1981), og at etablering av multiprofesjonelle team er en god ting i seg selv. Derfor er det neppe tilfeldig at organisering av team blir foreslått i offentlige utredninger, reformer og satsinger. Helse- og velferdstjenestene blir i mange ulike sammenhenger oppfattet som for sterkt preget av silotenkning, for mye spesialisering samt mangel på helhetlige løsningsstrategier, slik også politiske myndigheter oppfatter det. Tverrfaglige team blir da ansett som en mer fleksibel måte å organisere helse- og velferdsarbeid på, og et virkemiddel som kan redusere de samordningsproblemene som kjennetegner mange av tjenestene.

Både i sykehus, i mange kommunale helsetjenester og i arbeids- og velferdsetaten er det etter hvert blitt vanlig å arbeide i slike team. Bare de siste par årene har sentrale helsemyndigheter foreslått etablering av «primærhelseteam» (Helsedirektoratet, 2016), «oppfølgingsteam» for mennesker med komplekse og langvarige behov (Helsedirektoratet, 2018), HOD: Opptrappingsplanen for rusfeltet 2016-2020 samt ACT og FACT-team i arbeid med mennesker med rusproblemer og psykiske lidelser (Helsedirektoratet, 2017). Felles for disse forslagene er ønsket om å skape mer effektive og samordnete tjenester på ulike felt i denne sektoren.

Katzenbach og Smith (1992, s. 5) definerer «team» som «a small number of people with complementary skills who are committed to a common purpose, performance goals, and approach for which they hold themselves mutually accountable». Men i likhet med mange andre organisatoriske løsninger som lanseres i sektoren, er også kunnskapen om hvordan tverrfaglige team fungerer, fragmentert og lite systematisert. Tverrfaglige team er - som nevnt - ofte omsluttet av idealistiske oppfatninger om at de pr. definisjon er et godt tiltak. Her skal jeg problematisere denne oppfatningen. Med utgangspunkt i tre studier av tverrfaglige team skal jeg diskutere hvilke utfordringer og problemer i helse- og velferdssektoren som kan rettferdiggjøre etablering av tverrfaglige team. Deretter skal jeg ta for meg ulike måter slike team kan organiseres på, og hvilke forhold som synes å gjøre at noen team fungerer bedre enn andre. Er det mulig å utkrystallisere noen generelle lærdommer om hvordan 
teamarbeid fungerer - og som kan bidra til at team som en planlegger å etablere i sektoren, fungerer slik en ønsker at de skal? Det grunnleggende spørsmålet er: Hva skal til for at tverrfaglige team skal lykkes i sine intensjoner?

I dette kapittelet vil jeg først gjøre rede for ulike måter å organisere tverrfaglige team på. Deretter gjør jeg kort rede for noen av de faktorene som internasjonale oversikter av forskningen om team fremhever som viktige for at team skal «lykkes». På grunnlag av Reeves, Lewin, Espin \& Zwarenstein (2010) presenterer jeg så et analytisk rammeverk for empiriske studier av tverrfaglige team. Basert på dette rammeverket gjennomgår jeg noen av de analysene jeg sammen med kolleger har gjennomført de siste årene, der vi har studert tverrfaglige team i ulike deler av helse- og velferdssektoren.

\section{Datagrunnlaget}

De empiriske eksemplene som er valgt som utgangspunkt for drøftingen, er knyttet til studier/evalueringer jeg har deltatt $i$, der tverrfaglige team inngår i en strategi for å bedre kvaliteten på helse- og velferdstjenester. Studiene er valgt for å gi et bredt tilfang av empiri når man diskuterer hvordan tverrfaglige team fungerer. De teamene som ligger til grunn for diskusjonen, er:

- «ROP-team» $i$ arbeidet med rus og psykisk helse: Dette var samhandlingsteam i tilknytning til det såkalte Romeriksprosjektet (Hansen \& Ramsdal, 2015; Ramsdal \& Hansen, 2012; Ramsdal \& Hansen, 2017).

- «Overvektsteam» ved sykehuset: Dette er multidisplinære team som i særlig grad fokuserer på arbeidet med å behandle pasienter med overvektslidelser ved Sykehuset Østfold HF (Fineide, Bjørkquist \& Ramsdal, 2018).

- «NAV-team» $i$ velferdssektoren: Dette blir betegnet som «virksomhetsbaserte team» innenfor NAVs strategi for å redusere sykefraværet i kommunene (Ramsdal, Bjørkquist, Fineide, Haug \& Hansen, 2018). 
Disse tre prosjektene er valgt både fordi de viser variasjonsbredden i organisering av tverrfaglige team, og fordi de belyser problemstillinger $i$ organisering av og arbeid i team som kan bidra til en mer generell drøfting av forutsetningene for at tverrfaglige team kan lykkes i sine intensjoner. Med andre ord er det ikke en sammenlikning av de tre teamene som er hensikten her. Det dreier seg snarere om en strategisk utvelgelse av noen casestudier som kan belyse teoretiske poenger (Hoskela-Huotari, Edvardsson, Jonas, Sørhammar \& Witell, 2016; Stewart, 2012).

\section{Hvorfor etablere tverrfaglige team?}

Selv om teamorganisering har lange tradisjoner i helse- og velferdssektoren, er bevisstheten om hvorfor og hvordan team kan organiseres, blitt større de siste årene (Goodwin, 2016; Røvik, 2009).

Teamorganisering er kun én av mange måter å styrke samarbeid og samhandling mellom ulike aktører i helse- og velferdssektoren på. I klassisk organisasjonsteori har en argumentert for at det er mulig å identifisere ulike organisasjonsløsninger som «passer inn» i de oppgavene/ problemene en skal løse (Mintzberg, 1978; 1993; Thompson, 1967). Thompson pekte på at det er mulig å klassifisere problemer som organisasjoner skal løse, ved å skille mellom kjente og ukjente problemer på den ene siden og grad av kompleksitet på den andre. Grad av kjennskap til problemene og grad av kompleksitet i oppgaveløsning definerer hvorvidt en kan strukturere arbeidsoppgaver etter byråkratiske linjeprinsipper, eller om en må benytte mer profesjons-/kunnskapsbaserte og fleksible organisasjonsformer (Mintzberg, 1978; Stabell \& Fjeldstad, 1996: Thompson, 1967). For tverrfaglige team er tanken at en gjennom en optimal sammensetning av ulike spesialkunnskaper skal kunne fatte relativt raske, «omforente» beslutninger om hva som skal gjøres. Denne grunnleggende ideen innebærer at tverrfaglige team ikke kan forventes å fungere under alle omstendigheter. Tvert imot vil det være noen problemer/oppgaver som egner seg for tverrfaglig teamorganisering, mens andre ikke vil det. Eksempler på situasjoner der team ikke egner seg, kan være der en står overfor kjente og forutsigbare oppgaver. Slike vil ofte organiseres etter «standard operating procedures» $(\mathrm{SOP})$, der organisering etter 
byråkratiske regler er mer fordelaktig. Og i møte med problemer som defineres som «uregjerlige» («wicked problems») - der det er stor kompleksitet, og der kunnskapen om hvordan en skal løse dem, er mangelfullvil andre organisasjons- og arbeidsformer, for eksempel forhandlinger og nettverksorganisering, være mer passende (Rittel \& Webber, 1973; Stabell \& Fjeldstad, 1996).

Fra et organisasjonsteoretisk synspunkt bør en derfor være kritisk til å foreslå team uten først å ha avklart hvilke problemer og oppgaver som skal løses.

\section{Hvordan organisere tverrfaglige team i helse- og velferdssektoren?}

Innenfor helse- og velferdssektoren er organisering av ulike tjenester karakterisert ved en ekstrem variasjon. Noen mener å se en utvikling fra der en tidligere primært konsentrerte seg om å samordne aktiviteter gjennom linjeorganisasjoner, det som blir betegnet som standardisert, «byråkratisk» «verdikjede-tenkning», til mer komplekse blandingsformer. I økende grad taler en om effektivitet - gjerne forstått som kostnadseffektivitet - noe som innebærer at forløpstenkning og prosessbaserte modeller er blitt et mantra (Ramsdal \& Ramsdal, 2007; Porter \& Teisman, 2005). Men etter hvert har en innsett at dette ikke er optimal organisering, spesielt når en møter pasienter/brukere med komplekse og langvarige behov og/eller med usikre diagnoser. Her kreves det større grad av samordning. Nyere organisasjonsteori er derfor opptatt av at de utfordringene en står overfor i helse- og velferdssektoren, krever ulike løsninger for å ivareta hensynet til fleksibilitet i tjenesteyting, sammen med bedre koordinering og kostnadseffektivitet. Svaret på slike utfordringer er å organisere faglig arbeid basert på ulike modeller. Og behovet for kompetanse til å analysere hvilke koplinger mellom problemer og organisasjonsmodeller som er optimale, er derved også økende. Informasjonsutveksling gjennom nye (digitale) kanaler, koordinatorfunksjoner, etablering av felles møteplasser (som ansvarsgrupper), felles lokalisering og partnerskapsorganisering er noen svar på disse utfordringene (Berlin, Carlstrøm \& Sandberg, 2009). 
Tverrfaglige team er et annet svar. Etablering av slike team blir oppfattet som et av de sterkeste virkemidlene for økt samordning av tjenestene ut fra de alternativene som er nevnt foran:

Den mest intensive formen for samarbeid er når representanter fra ulike profesjoner og organisasjoner jobber kontinuerlig sammen mot felles mål i tverrfaglige team.

(Axelsson \& Axelsson, 2009, s. 149)

I tråd med de synspunktene fra klassisk organisasjonsteori som er skissert foran, er et velfungerende team tenkt å gi en mer effektiv arbeidsorganisasjon. Det skal skje gjennom en rask kopling av ulike kompetanser til bestemte oppgaver, og ved at rask tilgang på kompetent bredde- og dybdekunnskap skaper handlingskapasitet (Katzenbach \& Smith, 1993). Imidlertid er det verdt å merke seg at teamorganisering betoner en

prestisjefri samhandling i stedet for hierarkiske relasjoner ovenfra og ned. Dette er forutsatt å skulle redusere treghet mellom ulike profesjoner i arbeidet.

(Berlin mfl., 2009, s. 16-17)

Teamorganisering er imidlertid ikke et entydig begrep. Det opereres med ulike betegnelser, hvorav tre skal nevnes her: Tverrfunksjonelle team kjennetegnes ved at medlemmer hentes fra ulike virksomheter og beveger seg mellom teamarbeid og arbeid i disse «moderorganisasjonene». Et multiprofesjonelt team henter medlemmer fra ulike profesjoner og kompetanser fra en og samme organisasjon, som sammen løser oppgaver. Et multidisiplinoert team er sammensatt av medlemmer fra ulike kunnskapsområder (profesjoner), og som arbeider kun i teamet (Franklin, Bernhardt, Lopez, Long-Middleton \& Davis, 2015).

Som jeg skal komme tilbake til senere i kapittelet, er et av de viktigste skillene når det gjelder etablering av tverrfaglige team i sektoren, kontrasten mellom team som er tverrfunksjonelle (der en altså låner ressurser fra en «moderorganisasjon» til teamarbeid $\mathrm{i}$ et avgrenset funksjonsområde og med deltidsarbeid i teamet), og et multidisiplinært team (der ulike profesjoner arbeider likestilt og fulltid i teamet).

Hver av disse teamorganisasjonene møter særegne utfordringer. Øvretveit (1996) har gitt en oversikt over hvilke faktorer som fremmer 
og hemmer samarbeid i team. Han peker på fem forhold der han mener disse faktorene gjøres gjeldende: Det som fremmer godt samarbeid i team, er etter hans oppfatning et godt integrert team gjennom at teamdeltakerne føler et fellesskap, tar ansvar for helheten i arbeidet, og at det finnes reell tverrfaglighet med likeverdighet mellom de kunnskapsgrunnlag og profesjoner som er representert i teamet. I tillegg mener han at teamledelse må ha full instruksjonsmyndighet når det gjelder teamets arbeid. De to siste punktene peker mot at multidisiplinære team har større muligheter til å lykkes enn team som er organisert på andre måter. Skillet mellom tverrfunksjonelle og multidisiplinære team har betydning for forekomsten av faktorer som fremmer/hemmer samarbeid i teamet. Generelt vil multidisiplinære team ha bedre forutsetninger for å utvikle sterk integrasjon, helhetlig teamansvar, heltidsengasjement, tverrfaglighet og sterkere ledelse. Et tverrfunksjonelt team vil på sin side tendere mot å ha større grad av hemmende faktorer - ved at identiteten til teammedlemmene er delt mellom «moderorganisasjonen» og teamorganisasjonen, gjerne i det som betegnes som en matriseorganisasjon. Matriseorganisasjoner er generelt preget av utfordringer med ledelse og arbeidsfordeling mellom moderorganisasjonen og teamorganisasjonen (Røvik, 2009).

\section{Et rammeverk for analyser av tverrfaglige team}

Reeves mfl. (2010) er blant dem som er opptatt av at analyser av tverrfaglige team krever en bred tilnærming, der en utvider perspektivet fra den «tradisjonelle» fokuseringen på teamenes indre liv. De lanserer derfor et konseptuelt rammeverk som tar utgangspunkt i fire faktorer de mener gir grunnlag for en mer helhetlig forståelse av tverrfaglige team. Disse faktorene betegner de som kontekstuelle, organisatoriske, prosessuelle og relasjonelle. Modellen spesifiserer så ulike elementer som hver av disse faktorene preges av:

- Kontekstuelle: kultur, variasjon, kjønn, politisk vilje, økonomiske rammer. 
- Organisatoriske: organisasjonsstøtte fra det som kan betegnes som «driftsorganisasjonene» team inngår i, profesjonssammensetning, juridiske rammer / rettslig ansvar.

- Prosessuelle: tidsrammer for teamet, rutiner/ritualer, bruk av IT-teknologi, graden av kompleksitet i oppgaver.

- Relasjonelle: makt/hierarki, sammensetning av teamet, roller som de ulike teammedlemmene skal ivareta (Reeves mfl., 2010, s. 58).

Disse faktorene samspiller. Gjennom å avklare hvilke ulike måter de ivaretas på, kan en oppnå en mer realistisk, empirisk basert analyse av de tverrfaglige teamenes forutsetninger for å fungere etter intensjonene. Jeg skal her benytte dette rammeverket som en inngang til en drøfting av de tre tverrfaglige teamene som jeg sammen med kolleger har studert (se foran). Det er riktignok ikke mulig å foreta en fullstendig analyse av alle de faktorene/elementene som er presentert over, men en kan likevel gi et innblikk i hvordan rammeverket kan anvendes i relasjon til hvorfor teamene ble etablert, og til hvordan de fungerer. Jeg vil særlig fokusere på den helse- og velferdspolitiske og den organisatoriske konteksten teamene arbeidet innenfor, og hvilken betydning organiseringen av teamene har hatt.

\section{Noen studier av tverrfaglige team i ulike deler av helse- og velferdssektoren «ROP-team»}

Den studien det refereres til her, bygger på erfaringer med tverrfaglige team i tjenester knyttet til rus og psykisk helse i det såkalte Romeriksprosjektet. Evalueringen er basert på et omfattende datamateriale som ble samlet inn i to runder - i en midtveisrapport (Hansen \& Ramsdal, 2012) og en sluttrapport (Hansen \& Ramsdal, 2015). I begge omganger ble det samlet inn data ved hjelp av spørreskjema, deltakende observasjon på teammøter og gruppeintervjuer. I tillegg ble det foretatt intervjuer med prosjektleder, sentrale ledere i spesialisttjenestene for rus og psykisk helse 
i helseforetaket og i kommunale helse- og velferdstjenester (Hansen \& Ramsdal, 2012; Hansen \& Ramsdal, 2015).

Romeriksprosjektet var et lokalt initiativ, men knyttet til Helsedirektoratets arbeid med å utvikle bedre samordning og samarbeid mellom tjenestene for rus og psykiske helse - både horisontalt (mellom rustjenester og psykiske helsetjenester) og vertikalt (mellom de statlige spesialisttjenestene og de kommunale tjenestene (Helsedirektoratet, 2012). Den samarbeidsmodellen som ble utprøvd på Romerike, hadde tilknytning til modeller som ble etablert omtrent samtidig: ACT, FACT og Bærumsmodellen. Alle disse innbefattet etablering av tverrfaglige team, og samtlige ble og blir gjenstand for omfattende evalueringer (Andersen, 2013; Ramsdal \& Hansen, 2012; 2015; 2017; Ruud \& Landheim, 2012). Prosjektet Forpliktende samhandling om psykisk helse på Romerike (Romeriksprosjektet) arbeidet siden oppstarten i 2010 med å iverksette et systematisk og forpliktende samarbeid mellom syv kommuner, to distriktspsykiatriske sentre (DPS-er) og to ruspoliklinikker innenfor Divisjon for psykisk helsevern ved Akershus universitetssykehus.

Målet for prosjektet var å gi mennesker med alvorlige psykiske lidelser - alene eller i kombinasjon med rusproblemer, kognitiv svikt mv. - et helhetlig og sammenhengende behandlings- og tjenestetilbud. (Akershus HF, Prosjektbeskrivelse 2009). Det ble etablert sju samarbeidsteam, som senere ble redusert til fem. Teamene var sammensatt av ansatte ved ulike fagavdelinger fra spesialisttjenestene og kommunene. I prosjektbeskrivelsen het det at modellen forutsatte at prosjektet skulle styrke samhandling i de eksisterende driftsorganisasjoner, og at prosjektet derved skulle være et virkemiddel for å skape varige samhandlingsformer (Akershus HF, Prosjektbeskrivelse 2009).

Evalueringen viste at mange av de viktigste målene, som å skape bedre kommunikasjon og samarbeid, ble oppnådd. Dette var begrunnet i at deltakerne i teamene ble bedre kjent med hverandres kompetanser og arbeidsformer. Men evalueringen viste også at det var store utfordringer når det gjaldt forholdet mellom samhandlingsgruppene/teamene og de respektive driftsorganisasjoner om rekrutteringsgrunnlaget for pasienter, oppgavefordeling, ressurs- og tidsbruk. 


\section{«Overvektsteam»}

Dette er et multiprofesjonelt team ved Sykehuset Østfold HF (SØ HF). Gjennomgangen av dette teamet er basert på prosjektet Kvalitetsutvikling, pasientforløp og prosessforbedring (KUPP) (Fineide, 2018). Problemstillingen var her hvordan ulike tverrfaglige team på sykehuset ivaretar kvalitet/kvalitetsutvikling gjennom gode pasientforløp, og hvilke muligheter/utfordringer en finner i implementering av teamarbeidsmodellene. Datainnsamlingen var basert på dokumenter/konseptbeskrivelser samt dokumentasjon av utvikling i pasientbehandling/-forløp. Deretter ble det gjort to semistrukturerte fokusgruppeintervjuer med alle de ansatte i teamet (til sammen 17), og ett intervju med den kirurgiske overlegen som har det overordnete ansvaret for forløpsbeskrivelsen der overvektsteamet inngår.

Sykehuset Østfold HF har i mange år arbeidet med kvalitetsutvikling, pasientforløp og prosessforbedring (Ramsdal \& Bjørkquist, 2016, 2018). Overvektsteamet har som formål å planlegge av behandlingsopplegg, ta beslutninger om prioritering av pasienter og hvilken behandling (om noen) som skal benyttes. Ut fra nasjonale retningslinjer for forebygging og behandling av sykelig overvekt i utredning, og behandling av sykelig overvekt i spesialisttjenesten (Sosial- og helsedirektoratet, 2008), ble overvektsteamet etablert ved Sykehuset Østfold i 2013. Oppgavene til teamet er å gjennomføre motivasjonstiltak, utredninger av den enkelte pasientens fysiologiske og psykososiale forutsetninger for å gjennomføre behandling samt valg av behandlingsform (der særlig avgjørelse om «konservativ», motiverende behandling eller kirurgisk inngrep blir valgt). Begge disse valgene er forutsatt å avsluttes med etterbehandling/oppfølging. Teamet består i realiteten av to arbeidslag («team») som i prinsippet er likt sammensatt - med leger, sykepleiere, psykolog, ernæringspsykolog, fysioterapeut, sosionom og sekretær. Hvert av de to arbeidslagene hadde syv-ti ansatte. I tillegg kom den kirurgiske aktiviteten som hadde sin egen arbeidsform.

Analysen av overvektteamet viser at det blir ansett som svært vellykket, med den hovedbegrunnelsen at teamets tverrfaglige sammensetning og arbeidsmåte er godt innarbeidet i sykehusorganisasjonen, at de ansatte er fulltidsengasjerte i teamet, og at oppgavene er klart definert. 
Teamets kjerneteknologi er knyttet til selve beslutningsformen, der de enkelte representantene for fagprofesjonene først foretar en selvstendig vurdering av pasienten, basert på faglige standarder og vurderinger. Deretter samles teamet om en felles, omforent beslutning. Tidsrammene for gjennomføring av de ulike arbeidsoperasjonene er klart definerte, og er rutinemessig knyttet til at en faglig basert beslutning om pasientens behandlingsopplegg (eller avvisning) blir foretatt innenfor rammen av fastsatte møtepunkter. Uenighet og ulike vurderinger som forekommer mellom de deltakende faggruppene, må derfor avklares raskt, og i praksis skjer beslutninger uten at det er en hierarkisk orden i avgjørelsene som tas.

\section{«NAV-team»}

Dette dreide seg om etablering av såkalte "virksomhetsbaserte team» innenfor NAVs strategi for å redusere sykefraværet i kommunene, knyttet til et prosjekt kalt «NED-prosjektet» (Ramsdal mfl., 2018). Dette prosjektet var et initiativ for å finne nye arbeidsmåter for å nå målet om 20 prosent reduksjon i sykefraværet i utvalgte kommuner, og evalueringsprosjektet fokuserte på å forklare de faktorene som bidro til måloppnåelsen. Det ble benyttet to metoder i datainnsamlingen. Den første var dokumentasjon av resultater i form av oversikter, statistikk og sykefraværsanalyser. Resultatene derfra dannet grunnlaget for gruppeintervjuer og den videre innhentingen av data om organisering som kunne bidra til å gi en ytterligere kunnskap om utvikling i sykefraværet i de aktuelle kommuneorganisasjonene. Totalt ble det gjennomført 13 slike intervjuer. De som ble intervjuet var ansatte i de virksomhetsorganiserte teamene, kommunale ledere og prosjektleder i NAV.

Utgangspunktet for dette arbeidet var det nasjonale «NED-prosjektet» (NAV, 2015), der målet var å redusere sykefraværet (i offentlig sektor). I $\emptyset$ stfold ble det tatt initiativ til å forsterke denne nasjonale strategien med et eget prosjekt, kalt «NED med sykefraværet - IA-ledelse 2.0». Dette var et ettårig prosjekt som ble iverksatt av NAV Østfold. Det dreide seg om å gjennomføre forsøk med såkalte «virksomhetsbaserte team», der målet har vært å redusere sykefraværet i de fem bykommunene og i én 
nabokommune i fylket med i gjennomsnitt 20 prosent. Dette ble gjort ved at en etablerte fem team bestående av ansatte fra arbeidslivssenteret (IA) og kommunale NAV-kontor. Størrelsen på teamene varierte - fra tre til ti personer - og i utgangspunktet ønsket en personer med lang erfaring i arbeid med sykefravær fra de ulike delene av fylket. Den viktigste innovasjonen som var knyttet til etableringen av disse teamene, var at de skulle arbeide direkte opp mot sine respektive kommuner og konsentrere seg om de avdelingene/virksomhetene som hadde høyest sykefravær. Teamene tok dermed utgangspunkt i den sykemeldtes arbeidssted («virksomhet»), og ikke i fødselsårstall, som er vanlig i NAV. Gjennom tidlige samtaler med den sykemeldte og arbeidsgiverne/ledere i virksomhetene ble det avklart i hvilken grad og hvordan en kunne finne fleksible løsninger for den enkelte (ev. å konkludere med at sykemeldingen ble videreført).

Evalueringen viste at teamene bidro til at prosjektet langt på vei oppnådde sine tallfestete mål, med en markert reduksjon i sykefravær blant de virksomhetene som har deltatt. Denne reduksjonen varierte fra 20 til 40 prosent. Prosjektet førte også til at arbeidsgiver har fått ett kontaktpunkt for oppfølging av alle sine sykemeldte arbeidstakere, at oppfølgingen av sykemeldte har kommet i gang tidligere enn før, og at NAV-ansatte har fått utvidet beslutningsmyndighet (men ikke så mye som de mener er nødvendig for å gjøre jobben effektivt). Det er også klart at det gjenstår en del før de organisatoriske målsettingene er fullt ut ivaretatt (Ramsdal mfl., 2018).

\section{Noen momenter $\mathrm{i}$ analysen av teamene basert på Reeves mfl. (2010)}

Med utgangspunkt i de forholdene som Reeves mfl. mener er de mest sentrale for å forstå hvordan team fungerer, skal jeg her foreta en (relativt kortfattet og enkel) gjennomgang av de tre teamene vi har analysert. Utgangspunktet er de elementene som er knyttet til henholdsvis kontekstuelle, organisatoriske, prosessuelle og relasjonelle faktorer. Dette kan være et grunnlag for å forstå de utfordringene de tre team-organisasjonene møtte, ut fra de evalueringene vi har foretatt. 


\section{Kontekstuelle forhold}

ROP-teamet, innenfor rammen av Romeriksprosjektet, var politisk prioritert som ledd i utprøvingen av ulike måter å organisere lokale tjenester knyttet til rus og psykisk helse på. Sentrale fagmyndigheter finansierte og fulgte opp prosjektet. De ulike kommunene og spesialisttjenestene var involvert, de overførte ressurser (deltakere i teamet) og støttet prosjektet. Men våre intervjuer viste at mange i driftsorganisasjonene i kommunene og helseforetaket var ambivalente, $i$ likhet med noen av deltakerne i teamene. Dette hadde primært sammenheng med at prosjektet innebar at arbeid i samhandlingsgruppene ble ansett som ressursoverføring som gikk ut over driftsorganisasjonene.

Overvektsteamet var generert innenfra; det vil si at det var etablert som ledd i en helsepolitisk prioritering av pasienter med overvektsproblemer. Initiativet til teamet var en idé som var utviklet av fagpersoner internt på sykehuset. På sett og vis er teamet et eksempel på organisatoriske innovasjoner innenfor rammen av sykehusorganisasjoner, der en har funnet at ca. 80 prosent av innovasjoner i sykehus er utviklet gjennom nye måter å organisere og utføre medisinskfaglig arbeid på (Lévesque, 2012). Ut fra analysen fremgår det at teamet anses som en suksess i sykehusorganisasjonen.

NAV-teamet var etablert som et initiativ fra NAV Østfold, som ledd i en overordnet strategi for å avbyråkratisere og effektivisere arbeidet med sykefraværet, særlig i kommunal sektor. Teamene inngikk i en nasjonal strategi for dette, men forsterket denne strategien ved å gjøre teamene til en organisatorisk innovasjon som fikk tilslutning og ble fulgt med interesse av den nasjonale NAV-ledelsen. Teamene overoppfylte de kvantitative målene om reduksjon i sykefraværet i de aktuelle kommunene, samtidig som de bidro til å skape større nærhet til brukere og arbeidsgivere, og til å avbyråkratisere arbeidsformen til NAV på dette området.

\section{Organisatoriske forhold}

Tre vilkår er ifølge Reeves mfl. (2010) viktige når det gjelder organisatoriske forhold ved tverrfaglige prosjekt: 1) Om mål og oppgaver er klart definerte, 2) Forholdet mellom prosjekt- og driftsorganisasjon - i hvilken 
grad teamet er integrert i driftsorganisasjonen eller fungerer på utsiden i (en eller annen form for) matriseorganisasjon, og 3 ) teamdeltakernes grad av forpliktelse til teamet - der spørsmål om fulltidsdeltakelse i teamet (multidisiplinære team) eller ikke er sentralt. De tre teamene vi har studert, varierer når det gjelder disse forholdene.

ROP-teamene, som var Romeriksprosjektets samhandlingsgrupper, viste seg å ha relativt mange problemer med å avklare sine mål og oppgaver. Dette gjaldt særlig driftsorganisasjonens mangslungne utfordringer mht. pasientgrunnlag (problemer med rus og psykisk helse), arbeidsfordeling mellom ulike deler av spesialisttjenestene og kommunale tjenester, både horisontalt og vertikalt. Ettersom samhandlingsgruppene var et virkemiddel for å bidra til økt samarbeid mellom de ulike tjenestene på feltet, ble teamene også en del av den usikkerheten og de interessekonfliktene som hersket mellom tjenestene i driftsorganisasjonene de utgikk fra. Kort sagt ble samhandlingsgruppene organisatorisk «kilt inn» i de veletablerte siloene (særlig i spesialisttjenestene), tiltak og tjenester som de rekrutterte fra, og som de skulle kompensere for. ROP-teamene var eksempler på tverrfunksjonelle team, noe som innebar at de faktorene som bidrar til å hemme vellykket teamarbeid, var til stede.

Overvektsteamets og NAV-teamenes mål og oppgaver var på den annen side mer avgrenset, og ansett som relativt klart definert på forhånd. I overvektsteamet var det viktigste grepet at teamdeltakerne først individuelt gjennomførte undersøkelse av pasienten basert på faglige standarder for egen profesjon, og deretter samlet seg for en faglig omforent konklusjon om strategien for videre behandling av den enkelte pasient. Dette ble fremstilt som en meget tydelig, nærmest forbilledlig, rolleavklaring. Overvektsteamet var organisatorisk sett sterkt integrerte multiprofesjonelle team.

Uansett hvilken relasjon det var mellom team og driftsorganisasjon(er), var det $\mathrm{i}$ alle de tre teamene problemstillinger knyttet til dette forholdet. Som det fremgår over, hadde samtlige team ulik kopling til sine driftsorganisasjoner. ROP-teamene var definert som «samhandlingsgrupper», og skulle i prinsippet være deltidsdeltakere i teamene, mens de øvrige deltakerne arbeidet i driftsorganisasjonen. For den enkelte deltaker var dette et problem, i og med at det ble vanskelig å skille mellom oppgaver som ble 
lagt til teamene, og oppgaver som var driftsorganisasjonens ansvar. Det innebar også at teamene støtte på et legitimitetsproblem - der knappe personalressurser fra de ulike driftsorganisasjonene skulle avsettes til arbeid i teamene. I overvektsteamet var forholdet mellom driftsorganisasjon og team lite problematisert. Grunnen var åpenbart at teamet etter kort tid ble integrert som en ordinær, permanent virksomhet i sykehusets organisasjonsstruktur. Teamet hadde høy legitimitet innad i sykehusorganisasjonen, noe som kom til uttrykk ved at det ble tilført flere stillinger år om annet, til tross for generelle innstramminger når det gjaldt rekruttering av nytt personale til sykehuset. NAV-teamene var blitt rekruttert som en blanding av heltids- og deltidsdeltakere, men alle visste at dette var et midlertidig prosjekt av relativt kort varighet.

Det siste forholdet som er trukket frem her, er grad av deltakelse. I ROP-teamene var det en forutsetning at teamdeltakelsen var et deltidsengasjement, i og med at målet med prosjektet nettopp var at en skulle utprøve en modell der en - i motsetning til de øvrige lokale teammodellene en prøvde ut innenfor feltet - skulle ha sterkest mulig integrasjon mellom samhandlingsgruppenes arbeid og de mange og ulike driftsorganisasjonene i kommunene og spesialisttjenestene. I NAV-teamene var de fleste deltakerne deltidsansatte i teamet. Dette hadde deltakerne selv ulike oppfatninger av: For noen innebar det en stressfaktor å skulle fordele tid mellom team og drift, mens det for andre ble nevnt som en fordel å kunne «flekse» mellom oppgaver mellom de to. Det var generell enighet om at selv om denne arbeidsorganiseringen innebar at teamene var mindre organisatorisk integrerte enn det en fulltidsdeltakelse ville innebære, fungerte måten dette spørsmålet ble avklart på, relativt godt. I vår evaluering fremhever vi at det vellykkede resultatet av teamenes arbeid henger sammen særlig med to faktorer: For det første det svært eksakte og eksplisitt formulerte målet for arbeidet. For det andre selve arbeidsformen, med vektlegging av nærheten til de ulike virksomhetene og kontakten med de sykemeldte. På den annen side kan en spørre om det er arbeidsformen fremfor teamorganisasjonen som er avgjørende for at disse faktorene ble utslagsgivende. I overvektsteamet var deltidsengasjement bare en problemstilling for et par av de ansatte. Dette fremstår da også som et sterkt integrert team. 


\section{Prosessuelle forhold}

Jeg skal her konsentrere meg om to vilkår som fremstår som spesielt viktige med hensyn til prosessuelle forhold i de tre teamene: tidsrammer og graden av kompleksitet i oppgaver.

ROP-teamene var preget av at Romerriksprosjektet var tidsavgrenset, som et prosjekt med en varighet på fire år. NAV-teamene på sin side hadde, som ledd i NED-prosjektet, en relativt stram tidsramme - kun to år. Overvektsteamet er på den annen side å oppfatte som et permanent team, som en del av sykehusets ordinære driftsorganisasjon. Det er liten tvil om at tidsramme er viktig: For NAV-teamenes del innebar det at en måtte fremvise resultater raskt, og dokumentasjonen av sykefraværet gjennom ukentlige (skype-)møter understreket dette. For ROP-teamenes del var det først og fremst en utfordring at det tok lang tid (i praksis et par år) før en hadde et relativt klart grunnlag for å arbeide effektivt i prosjektet. Tidsrammen fikk derfor ulike konsekvenser for de tre temaorganisasjonene vi studerte.

Graden av kompleksitet i oppgaver representerer på mange måter grunnlaget for at team etableres, slik vi har påpekt foran. I vår sammenheng er det tre forhold som er viktige: 1) Hvorvidt målgruppens problemer/lidelser som teamenes arbeid dreier seg om, er klart definert eller ikke, 2) om kunnskapssammensetningen i teamet kan dekke oppgavene, og 3) om det finnes operative standarder som kan bidra til å «løse» de oppgavene som målgruppene har.

Også her er det variasjoner mellom de tre teamorganisasjonene vi tar for oss: Romeriksprosjektets ROP-team arbeidet med mennesker med lidelser knyttet til rus og psykisk helse, gjerne i kombinasjon (såkalte ROP-lidelser). En rekke forfattere har pekt på at disse lidelsene, også kalt «wicked problems, er blant de mest utfordrende i velferdsstaten (Rittel \& Webber, 1973; Vabø \& Vabo, 2014). Slik det fremgår av intervjuene med deltakerne i teamene, er dette anerkjent som en av grunnene til den usikkerheten og noen av de samordningsproblemene en opplevde i de ordinære tjenestene, og som i sin tur smittet over på teamenes arbeid. Å finne en felles strategi for tiltak for målgruppen kunne være vanskelig - ettersom deltakerne representerte ulike fagtradisjoner og kom fra tjenester som hadde ulike faglige perspektiver. Det var derfor ikke alltid 
enighet om hvilke strategier som skulle velges i behandlingen. Men gjennom noen av de nye teknologiene som ble introdusert, som «tavlemøter» med digitale hjelpemidler, ble en stort sett enig om hvordan arbeidet med den enkelte pasient skulle foregå, gitt at en var enig om hvilket nivå pasientens problemer til enhver tid befant seg på (Hansen \& Ramsdal, 2015).

Også pasientgrunnlaget for overvektsteamet var preget av komplekse avveininger - særlig med hensyn til pasientenes motivasjon for å gjennomføre de tiltakene som krevdes, og hvorvidt kirurgiske inngrep skulle anbefales. Her var utvelgelsen av de pasientene som skulle inngå i teamets arbeid det viktigste beslutningsgrunnlaget. Og når denne beslutningen var tatt, fremsto kunnskapsgrunnlaget for det videre arbeidet som relativt klart, selv om en var opptatt av at «overvekt» er en svært kompleks blanding av fysiologiske og psykiske faktorer. De operative kravene til utførelsen av dette arbeidet fremsto likevel som relativt standardiserte.

For NAV-teamene var avklaringen av hvilke brukere (sykemeldte) en skulle konsentrere arbeidet om, det viktigste beslutningspunktet. Det dreide seg om å anvende erfaring fra tidligere arbeid med sykefravær som et viktig grunnlag, der en vurderte både den enkeltes potensielle arbeidsevne og arbeidsorganisasjonens grad av fleksibilitet for å finne tilpassede løsninger. Svært mange av de som teamene arbeidet med, var arbeidstakere med diffuse psykososiale problemer, muskel- og skjelettlidelser etc. dvs. de som utgjør den største andelen av sykemeldte. Ettersom teamene var rekruttert av både kommunalt NAV-ansatte og IA-ansatte, innebar dette at en kunne kombinere to typer kompetansebakgrunn. Mens problemene var komplekse, var arbeidet kjennetegnet av at en ut fra de to kunnskaps- og erfaringsgrunnlagene teammedlemmene hadde, kunne foreslå fleksible løsninger. Dette skjedde i samarbeid mellom den sykemeldte, arbeidsgiver og NED-teamet. Resultatet var at de overordnete målene for den nasjonale moderniseringsstrategien for NAV ble operasjonalisert i prosjektert på en relativt uavhengig måte, uten for mange sideblikk til de mer «byråkratiske» arbeidsformene som ellers preger NAV. Det ble lagt vekt på at det ikke fantes standardiserte løsninger, men tilrettelegging for individuelt tilpassede tiltak som bidro til at flere kom tilbake til arbeid. 


\section{Relasjonelle forhold}

Her dreier det seg primært om teamenes «indre liv» - om maktrelasjoner, sammensetning av teamene og rollene som teammedlemmene utformer. Etter min vurdering blir det i for mange sammenhenger lagt nærmest ensidig vekt på relasjonelle forhold når teamarbeid diskuteres. Men uansett vil også slike forhold være viktige. Dersom de bryter sammen, vil teamet lett gå i oppløsning som effektivt arbeidsfellesskap. Og noen ganger kan gode relasjoner skape effektive team gjennom å kompensere for svakheter med de øvrige forholdene som er diskutert her, for eksempel at en arbeider innenfor tverrfunksjonelle team. Samtidig er det potensielt duket for problematiske maktrelasjoner i helse- og velferdssektoren, der særlig legeprofesjonens rolle som faglig ansvarlig skaper en risiko for ubalanse i relasjonene samt maktkonflikter.

I de tre teamene var det noe ulike oppfatninger av relasjonelle forhold. Interessant nok var det ikke i overvektsteamet, som besto av flere sterke fagprofesjoner, at makthierarkier ble ansett som et problem. Tvert imot var det her en oppfatning av likeverdighet - noe som kan forklares ved at en hadde klart definerte roller knyttet til de arbeidsoppgavene som var tildelt representantene for de ulike fagprofesjonene. Heller ikke i NAV-teamene ble hierarkiske relasjoner ansett som et problem. Det ble tvert imot fremhevet at det var erfaring, snarere enn faglig bakgrunn, som skapte en naturlig autoritet når det gjaldt å finne løsninger. Når det gjaldt ROP-teamene og Romeriksprosjektet var det derimot en rekke konfliktfylte relasjoner, både ved at psykiatere fremsto som klassiske «legeledere», og ved at en opplevde hierarkiske relasjoner mellom spesialisttjenestene og de kommunale tjenestene som noen ganger smittet over på teamene. Igjen ser vi at egenskaper ved målgruppen, arbeidets kopling til driftsorganisasjoner samt kontekstuelle forhold som teamene arbeider innenfor, har betydning for relasjonelle forhold. Det er derfor vanskelig å studere teamenes funksjon når det gjelder relasjonelle forhold uten å forstå de rammene som relasjonene utformes innenfor. 


\section{Drøfting}

De tre eksemplene som er skissert foran, illustrerer variasjonsbredden i det vi med en fellesbetegnelse har kalt tverrfaglige team. Selv om de er forankret i ulike deler av helse- og velferdstjenestene, er ulikt sammensatt og inngår i ulike organisatoriske kontekster, har de likevel noen viktige fellestrekk:

For det første dreier det seg om etablering av team på politisk og helseog sosialfaglig prioriterte områder. Dette burde tilsi at forutsetningene for å få legitimitet og (materiell) støtte i arbeidet bør være til stede. For det andre er etableringen av teamene forsøk på å finne nye løsninger for arbeid med komplekse samfunnsproblemer innen de respektive fagfeltene. Kompleksiteten varierer likevel. Organisering av tjenester for mennesker med rusproblemer og psykiske lidelser er preget av usikkerhet og til dels uenighet (Forsetlund mfl., 2012; Helsetilsynet 2016), med hensyn til både avgrensing av pasientgruppen og arbeids- og behandlingsformer (Ramsdal \& Hansen, 2016). Arbeid med å redusere sykefraværet er også preget av usikkerhet. De grunnleggende årsakene til økende sykefravær er komplekse, og det er vanskelig å finne konkrete strategier for å demme opp for dem (Stortinget, 2016). Disse to områdene er blitt betegnet som preget av «uregjerlige» problemer («wicked problems») (Rittel \& Webber, 1978; Vabo \& Vabø, 2014). Sykelig overvekt fremstår som et komplekst, men likevel et lettere identifiserbart og avgrenset problemfelt, selv om strategier for å «løse» det i et folkehelseperspektiv er svært utfordrende. Også behandlingen av den enkelte pasient er preget av å være meget komplekst, og ha usikre resultater (Sosial- og helsedirektoratet, 2008). I alle disse sammenhengene kan etablering av tverrfaglige team være eksempler på at en søker å finne nye - eller justere gamle - løsninger når det gjelder organisasjons- og arbeidsformer.

Med utgangspunkt i de tre analysene som er referert til over, kan en peke på noen momenter som synes å ha betydning for i hvilken grad teamene lykkes i sine intensjoner:

For det første er definisjonen av målgruppe viktig: I de teamene vi har studert, er det store variasjoner i hvordan målgruppen avgrenses: I rus-/ psykiatritjenestene var det uklarhet og til dels uenighet om hvordan målgruppen for teamenes arbeid skulle defineres. I overvektsteamet var det 
på sin side relativt klart definerte inntakskriterier (BMI), men her var det en utskilling av pasienter basert på en mer omfattende vurdering av motivasjon, psykososiale forhold og somatiske tilleggssykdommer som var avgjørende. I NAV-teamene var det teammedlemmene som initialt definerte brukere som egnet seg for å bli gjenstand for en mer aktiv hjelpeprosess, noe som i sin tur utløste den videre sammenkoplingen av brukere, arbeidsgivere og NAV-konsulenter. Det bildet som avtegner seg, innebærer at avklaringene av målgruppe - eller mangel på sådanne avklaringer - som skjedde ved opprettelse av teamene, hadde følger for hvorvidt teamene fikk arbeidsbetingelser som skapte konstruktive løsninger for brukerne.

For det andre er organisatorisk kontekst viktig. Her er det særlig sammenhengen mellom driftsorganisasjon(er) og team som er i fokus. I rus-/ psyk-tjenestene var det en utfordring å etablere team innenfor rammene av et mangfold av tiltak og tjenester - ved at de skulle «kiles inn» i tjenestesystemet. I tillegg var teamene basert på deltakelse fra både spesialisttjenester og kommunale tjenester. Dermed ble den organisatoriske konteksten kompleks, og avklaringen av arbeidsfordeling var i utgangspunktet uklar når det gjaldt mange (potensielle) pasienter. I virksomhetsteamene var imidlertid konteksten enklere, siden de hadde et klart definert mandat som skilte teamene fra den øvrige virksomheten. I forbindelse med overvektsteamet var den organisatoriske konteksten preget av at teamet fungerte i tråd med arbeidsformer som var veletablerte på sykehuset. Her var ledelsesstruktur og organisatorisk forankring i driftsorganisasjonen avklart.

For det tredje styrker de analysene vi har foretatt av de tre teamene, oppfatningen om at team sammensatt av heltidsansatte - sammen med at de arbeider innenfor rammen av en bestemt organisatorisk enhet, med andre ord kombinasjon av multidisiplinære og tverrfunksjonelle team er den mest effektive organiseringen. Dette var tilfellet i overvektsteamet, og delvis i NAV-teamene. På den annen side er det mer utfordrende å organisere team som trekker ansatte med ulike faglige kompetanser inn fra ulike tjenester, det vil si tverrfunksjonelle team. Basert på de tre teamene som er diskutert over, kan en hevde at det er de som er organisert i samsvar med de kravene som i team-litteraturen anses som optimale, 
som faktisk har klart seg best. Her kan en konstatere at team som er multidisiplinære, i kombinasjon med å være tverrfunksjonelle, opplever færrest utfordringer med å samordne arbeidet.

\section{Oppsummering}

I tråd med Katzenbach og Smith (1992, s. 93) har jeg her tatt utgangspunkt i en pragmatisk, relativt åpen definisjon av hva team er. Likevel er det noen kjennetegn som er viktige: Det dreier seg om grenser med hensyn til størrelse, hvilke kunnskaper teammedlemmer kan bidra med, og at en må sikre at arbeidet preges av en grunnleggende forståelse av mål og hensikt. Teamorganisering er bare én måte å skape fleksible, effektive arbeidsformer på for å nå disse målene. Her har jeg prøvd å vise mangfoldet i organisering av team, og særlig vektlagt behovet for å vurdere kritisk i hvilke sammenhenger etablering av team kan være en effektiv løsning. Et fellestrekk for å kunne utvikle effektive team er at en også gir ressurser, tid og rom for at team kan fokusere på de oppgavene de er satt til å løse, og at en har avklart hvilke bidrag teamorganisering skal ha i konkrete sammenhenger.

\section{Referanser}

Andersen, S. (2012). Nasjonal faglig retningslinje for utredning, behandling og oppfølging av personer med samtidig ruslidelse og psykisk lidelse - ROP-lidelser (Nasjonale retningslinjer (Helsedirektoratet)). Oslo: Helsedirektoratet.

Akerhus HF (2009). Prosjektbeskrivelse Romeriksprosjektet, Lørenskog

Andersen, B.J. (2013). Samhandlingsteamet i Bærum, S Flex-modellen. Praksis og effektevaluering. Tidsskrift for psykisk helsearbeid, 8(2), 154-162.

Axelsson, S. \& Axelsson, R. (2009). Multidiciplinera team och ledarskap - från revirtankande til altruism. I Berlin, J., Carlstrøm, E. \& Sandberg, H. (Red.), Team $i$ vård, behandling och og omsorg (s. 149-169). Lund: Studentlitteratur.

Belbin, M. (1981). Management teams. London: Heinemann.

Berlin, J., Carlstrøm, E. \& Sandberg, H. (2009). Team i vård, behandling och og omsorg - erfarenheter och reflektioner. I Berlin, J., Carlstrøm, E. \& Sandberg, H. (Red.), Team i vård, behandling och og omsorg (s. 15-24). Lund: Studentlitteratur.

Fineide, M.J., Bjørkquist, C. \& Ramsdal, H. (2018). Kvalitetsutvikling, pasientforløp og prosessforbedring - KUPP - Prosjektbeskrivelse. Høgskolen i Østfold, Avd. for helse og velferd. 
Forsetlund L., Lidal, I.B. \& Austvoll-Dahlgren, A. (2012). Effekter av ulike organiseringstiltak for tjenester innen psykisk helsevern (Kunnskapssenteret rapport nr. 05-2012). Oslo: Nasjonalt kunnskapssenter for helsetjenesten.

Franklin, C., Bernhardt, J., Lopez, R., Long-Middleton, E. \& Davis, S. (2015). Interprofessional teamwork and collaboration between community health workers and healthcare teams: An integrative review. Health Services Research and Managerial Epidemiology, 2, 2333392815573312.

Goodwin, N. (2016). Understanding integrated care. International Journal of Integrated Care 16(4)6, 1-4. https://doi.org/10.5334/ijc.2530.

Hansen, G.V. \& Ramsdal, H. (2015). Forpliktende samhandling om psykisk helse på Romerike («Romeriksprosjektet») - Sluttevaluering (Oppdragsrapport 2015:2). Halden: Høgskolen i Østfold.

Helsedirektoratet (2016). Primœrhelseteam. Overordnet skisse til forsøk med primorhelseteam. (Rapport nr. IS-2546, 10/2016). Oslo: Helsedirektoratet.

Helsedirektoratet (2017). ACT og FACT-team. Oslo: Helsedirektoratet.

Helsedirektoratet. (2018). Pilot for oppfølgingsteam. Strukturert tverrfaglig oppfølgingsteam - Innhold og gjennomføring av pilot (Rapport nr. hdir 12.03.2018). Oslo: Helsedirektoratet.

Helse- og omsorgsdepartementet (2015). Opptrappingsplanen for rusfeltet (20162020) Prop. 15 S (2015-2016), Innst. 240 S (2015-2016). Oslo: Helsedirektoratet.

Helsetilsynet (2016). Risikovurdering av tjenester til personer med samtidig ruslidelse og psykisk lidelse (Rapport 3/2016). Oslo: Statens helsetilsyn.

Hoskela-Huotari, K., Edvardsson, B., Jonas, J.M. Sørhammar, D. \& Witell, L. (2016). Innovation in service ecosystems - breaking, making, and maintaining institutionalized rules of integration. Journal of Business Research, 69(8), 2964-2971.

Katzenbach, J.R. \& Smith, D.K. (1992). Why teams matter. The McKinsey Quarterly, 3(Summer 1992). Retrieved from https://link.galegroup.com/apps/doc/A13857017/ $\mathrm{AONE} ? \mathrm{u}=$ googlescholar\&sid $=\mathrm{AONE} \& \mathrm{xid}=2 \mathrm{ee} 35 \mathrm{c} 78$

Lévesque, B. (2012). Social innovation and governance in public management systems: Limits of npm and search for alternatives? Collection Études théoriques. Montreal: Centre de recherche sur les innovations sociales.

Melding til Stortinget nr. 33 (2015-2016). NAV i en ny tid - for arbeid og aktivitet. Oslo: Arbeids- og sosialdepartementet.

Mintzberg, H. (1979/1993). The structuring of organizations - a Synthesis of the research. Englewood Cliffs, NJ: Prentice Hall.

Porter, M.E. \& Teisman, E.O. (2006). Redefining health care: Creating value-based competition on results. Boston, MA: Harvard Business School Press.

Ramsdal, H. \& Bjørkquist, C. (2019). Value-based innovations in a Norwegian hospital: From conceptualisation to implementation. Sendt Public Management Review, under vurdering. 
Ramsdal, H., Bjørkquist, C., Fineide, M.J., Haug, E. \& Hansen, G.V. (2018). Tidlig ute og tett på. Evaluering av virksomhetsbaserte team som ledd $i N A V$-prosjektet «Ned med sykefravceret - IA-ledelse2.o» (Oppdragsrapport 2018:1). Fredrikstad: Høgskolen i Østfold.

Ramsdal, H. \& Hansen, G.V. (2012). Forpliktende samhandling om psykisk helse på Romerike («Romeriksprosjektet») - Underveisevaluering (Oppdragsrapport 2012:2). Halden: Høgskolen i Østfold.

Ramsdal, H., \& Hansen, G.V. (2017). The organisation of local mental health services in Norway. Evidence \& Policy: A Journal of Research, Debate and Practice, 13(4), 605-622. https://doi.org/10.1332/174426416X14715382995623

Reeves, S., Lewin, S., Espin, S. \& Zwarenstein, M. (Red.) (2010). Interprofessional teamwork for health and social care. Oxford, UK: Wiley-Blackwell.

Rittel, H. \& Webber, M. (1973). Dilemmas in a general theory of planning. Policy Sciences, 4, 155-169. Amsterdam: Elsevier Scientific Publishing Company, Inc.

Ruud, T. \& Landheim, A. (2014). Evaluering av 12 ACT-team i Norge. Hva viser resultatene? Oslo: Akershus Universitetssykehus og Nasjonal kompetansetjeneste for samtidig rusmisbruk og psykisk lidelse.

Røvik, K.A. (2009). Moderne organisasjoner. Trender i organisasjonstenkningen ved årtusenskiftet. Bergen: Fagbokforlaget.

San Martín-Rodríguez, L., Beaulieu, M.D., D’Amour, D. \& Ferrada-Videla, M. (2005). The determinants of successful collaboration: A review of theoretical and empirical studies. Journal of Interprofessional Care, 19(1), 132-147.

Stabell, C.B. \& Fjeldstad, Ø.D. (1996). Configuring value for competitive advantage: on chains, shops, and networks. Strategic Management Journal, 19, 413-437.

Stewart, J. (2012). Multiple-case study methods in governance-related research. Public Management Review, 14(1), 67-82.

Stortinget. (2016b). Team - tilgjengelighet, tverrfaglighet og koordinering. Oslo: Helse- og omsorgskomiteen.

Thompson, J.D. (1967). Organizations in action. New York: McGraw-Hill.

Vabø, M. \& Vabo, S.I. (Red.) (2014). Velferdens organisering. Oslo:

Universitetsforlaget.

Øvretveit, J. (1996). Five ways to describe a multidisciplinary team. Journal of Interprofessional Care, 10(2), 163-171. 



\title{
KAPITTEL 5
}

\section{Koordinatorordninger som samordningstiltak - tre mulige paradokser}

\author{
Erlend Vik
}

Avdeling for økonomi og samfunnsvitenskap, Høgskolen i Molde

\section{Turid Aarseth}

Avdeling for økonomi og samfunnsvitenskap, Høgskolen i Molde

\begin{abstract}
Sammendrag: Koordinatorordninger i helsetjenesten er temaet for dette kapittelet, der vi undersøker både bakgrunnen for og spesielle utfordringer ved denne typen samordningstiltak. Det teoretiske utgangspunktet er Luhmanns systemteori og en forståelse av helsetjenesten som funksjonelt differensiert. Samordning handler her om å kunne få til kobling mellom ulike delsystemer.

Vi ser samhandlingsreformen som et tidsskille, og har gjennomført en dokumentanalyse av nasjonale styringsdokumenter i perioden 2008-2018. Gjennomgangen avdekket 14 ulike koordinatorordninger, hvorav åtte var spesifikt rettet mot pasienter med sammensatte behov. Problembeskrivelsene i styringsdokumentene og trekk ved utformingen av koordinatorordningene danner grunnlag for å identifisere tre mulige paradokser. Det første handler om at koordinatorordningene - gjennom å være opptatt av å håndtere grenser mellom delsystemer - kan bidra til å bevare den funksjonelle differensieringen heller enn å redusere den. Det andre viser til at selve organiseringen av koordinatorordningene kan forsterke den funksjonelle differensieringen, mens det tredje synliggjør at ordningene i seg selv bidrar til økt kompleksitet, ved at det oppstår behov for å koordinere koordinatorene.
\end{abstract}

Nøkkelord: koordinator, pasienter, sammensatte behov, systemteori, samordning, primær- og spesialisthelsetjeneste

Sitering av dette kapitlet: Vik, E., \& Aarseth, T. (2019). Koordinatorordninger som samordningstiltak tre mulige paradokser. I C. Bjørkquist \& M. Jerndahl Fineide (Red.), Organisasjonsperspektiv på samordning av helse- og velferdstjenester (s. 119-143). Oslo: Cappelen Damm Akademisk. https://doi.org/10.23865/ noasp.66.ch5.

Lisens: CC BY 4.0 


\section{Innledning}

Koordinering regnes som en av de eldste og største utfordringene i offentlig sektor (Bouchaert, Peters \& Verhoest, 2010). Særlig i helsetjenesten er behovene for koordinering store, gitt spesialisering og organisasjonsgrenser som i liten grad er tilpasset pasienter med sammensatte og langvarige hjelpebehov. Samhandlingsreformen St.meld. nr. 47 (2008-2009) kan ses som en bekreftelse på at arbeidet for å sikre mer helhet i pasientomsorgen har blitt en politisk og helsefaglig kjernesak (Hagen \& Johnsen, 2013; Vik, 2018). Både i tilknytning til selve reformen og til den videre oppfølgingen lanseres ulike koordinatorordninger som virkemidler for økt samordning. Slike ordninger er ikke noe særnorsk fenomen, og de inngår i repertoaret av samordningsstrategier i en stadig mer spesialisert og kompleks helsetjeneste (Andersson, Ahgren, Axelsson, Eriksson \& Axelsson, 2011).

Utgangspunktet for dette kapittelet er et spørsmål om koordinatorordninger har noen særtrekk som på en grunnleggende måte gjør at de skiller seg fra andre virkemidler. Mens for eksempel teamorganisering, samlokalisering, hospitering og partnerskap er innrettet mot å utfordre og bryte ned profesjonelle og organisatoriske grenser i helsetjenesten, kan det synes som om koordinatorordningene først og fremst er orientert mot å håndtere disse grensene. I så fall er det behov for innsikt både i innholdet i koordinatorordningene og i hvilke konsekvenser de kan tenkes å ha når målene om økt samordning i helsetjenesten skal realiseres. Vår utforskning er inspirert av Luhmanns systemteori (1993) og en forståelse av helsetjenesten som funksjonelt differensiert. Med dette menes at helsetjenesten ses som et system bestående av flere delsystemer som opprettholder hver sine funksjoner, eksempelvis i form av ulike profesjoner, organisatoriske enheter og forvaltningsnivåer. Samordningsutfordringene dreier seg da om hvordan man kan oppnå sammenkobling mellom de ulike delsystemene, slik at tjenestetilbudet fremstår som helhetlig.

Selve koordinatorbegrepet skaper positive forventninger om at det skal skje en ønsket sammenkobling mellom aktører og/eller tjenester. Begrepet representerer også en sentral kjerne i organisasjonsteorien, og er særlig vektlagt i teoritradisjoner som er opptatt av hvordan organisasjonsformer (konfigurasjoner) er koblet til ulike koordineringsmekanismer (for eksempel Mintzberg, 1979). Begrepsbruken i politikk, praksis og 
forskning fremstår imidlertid som mangfoldig og med uklar kobling til organisasjonsteoretiske posisjoner. Internasjonalt benyttes begrep som for eksempel patient navigator (Paskett, Harrop \& Wells, 2011), case coordinator (Neal, Brown \& Rojjanasrirat, 1999) og care coordinator (Walsh mfl., 2010). Begrepsvariasjonen er forankret både i diagnosegrupper og i organisatorisk tilknytning. Norsk forskning gjenspeiler denne variasjonen. Blant annet er det en rekke studier av kreftkoordinatorordningen, først og fremst i primærhelsetjenesten (Lie, Hauken \& Solvang, 2018; Melby, Das, Halvorsen \& Steihaug, 2017; Syse \& Moshina, 2015), men også av pakkeforløp i spesialisthelsetjenesten (Avila, Eide \& Vaage, 2016). I tillegg til studier av diagnosebaserte ordninger finnes forskning om koordinatorordningen i individuell plan (Ahgren, 2014; Kjellevold, 2014). Videre kan vi nevne Høyem, Gammon \& Steinsbekks (2018) studie av koordinator og kontaktlege i spesialisthelsetjenesten samt Gjerde, Torsteinsen \& Aarseths (2016) arbeid som belyser ulike sider ved kommunale koordinerende enheter.

På samme måte som ved tverrfaglige team (Ramsdal, 2019) bærer forskningen om koordinatorordninger preg av å være kontekstspesifikk og lite koblet til en mer overordnet forståelse av bakgrunnen for og innholdet i det samordningsvirkemiddelet en her tar i bruk. Vårt utgangspunkt er et annet. Vi vil ikke fokusere på en bestemt type ordning, men på koordinatorordninger ${ }^{1}$ som fenomen. Vi avgrenser oss til å studere trekk ved nyere politikkutforming med samhandlingsreformen som startpunkt, og har gjennomført en innholdsanalyse av ulike styringsdokumenter, tre stortingsmeldinger og fire veiledere fra Helsedirektoratet.

På det empiriske plan har artikkelen en selvstendig verdi ved å gi en oversikt over eksisterende koordinatorordninger. Selve analysen og fortolkningene av den er teoretisk informert av Luhmanns systemteori (1982; 1993), og skiller seg fra tidligere studier av spesifikke koordinatorordninger særlig på to måter. For det første er vi opptatt av å forstå hvordan koordinatorordninger samlet sett begrunnes og utformes av nasjonale myndigheter. For det andre ønsker vi å vise hvordan ordningene bidrar

1 Vi bruker begrepene koordinator og koordinatorordninger om hverandre. 
til å håndtere samordningsutfordringer i en funksjonelt differensiert helsetjeneste.

Problemstillingene er formulert som to spørsmål om kjennetegn ved og begrunnelser for koordinatorordninger og ett spørsmål som åpner for å avdekke utfordringer og mulige paradokser knyttet til denne formen for samordningstiltak.

1. Hvilke koordinatorordninger finnes i helsetjenesten?

2. Hvordan beskrives forholdet mellom samordningsbehov og løsning i form av koordinatorordninger?

3. Hvilke konsekvenser kan koordinatorordninger ha i en funksjonelt differensiert helsetjeneste?

Med utgangspunkt i en dokumentanalyse identifiserer og drøfter vi tre mulige paradokser koordinatorordningene som samordningstiltak kan representere. Det første handler om hvordan ordningene påvirker differensieringen i helsetjenesten. Det andre er knyttet til hvordan man har valgt å organisere koordinatorene, mens det tredje dreier seg om behovet for å koordinere koordinatorene.

\section{Metode}

Datamaterialet er valgt ut etter en kartlegging av aktuelle dokumenter i perioden 2008-2018 med tilknytning til samhandlingsreformen. Vi omtaler dem som styringsdokumenter, og inkluderingen er basert på subjektive relevanskriterier. For eksempel har vi bare inkludert én veileder for pakkeforløp i spesialisthelsetjenesten, da denne typen veiledere har en tilnærmet felles beskrivelse av hva en koordinator er og skal gjøre. Tidsavgrensningen kan problematiseres. Også før samhandlingsreformen ble innført, ble koordinatorordninger sett på som aktuelle samordningstiltak, og spesielt i St.meld. nr. 21 Ansvar og meistring (1998-1999) er koordinatoren sentral. Vi vil likevel argumentere for den valgte avgrensingen ut fra en oppfatning om at samhandlingsreformen representerer et tidsskille, og der samordning er blitt det sentrale målet for helsepolitisk styring (Hagen \& Johnsen, 2013).

De inkluderte dokumentene er nummerert i kronologisk rekkefølge. 


\begin{tabular}{|l|l|c|}
\hline 2008 & $\begin{array}{l}\text { Samhandlingsreformen - Rett behandling - på rett sted - til rett tid } \\
\text { (St.meld. nr. 47 (2008-2009)) }\end{array}$ & 1 \\
\hline 2014 & Fremtidens primærhelsetjeneste (St.meld. nr. 26 (2014-2015)) & 2 \\
\hline 2015 & Nasjonal helse- og sykehusplan (St.meld. nr. 11 (2015-2016)) & 3 \\
\hline 2016 & Kontaktlege i spesialisthelsetjenesten (Helsedirektoratet, 2016) & 4 \\
\hline 2018 a & $\begin{array}{l}\text { Pakkeforløp for kreft - Generell informasjon for alle pakkeforløpene for } \\
\text { kreft (Helsedirektoratet, 2018a) }\end{array}$ & 5 \\
\hline $2018 b$ & $\begin{array}{l}\text { Veileder om oppfølging av personer med store og sammensatte behov } \\
\text { (Helsedirektoratet, 2018b) }\end{array}$ & 6 \\
\hline $2018 c$ & $\begin{array}{l}\text { Veileder om rehabilitering, habilitering, individuell plan og koordinator } \\
\text { (Helsedirektoratet, 2018c) }\end{array}$ & 7 \\
\hline
\end{tabular}

Tabell 1. Datagrunnlag sortert etter tidslinje.

Analysen av dokumentene er gjort i tre steg. Først ble det gjennomført en full gjennomlesning for å identifisere kjennetegn ved de ulike koordinatorordningene og generelle trekk ved problembeskrivelsene. Deretter ble analysen spisset mot hvordan koordinatorordninger forstås som en løsning på samordningsutfordringene. Alle tekstutdrag som inneholdt ordet koordinator, ble lagt inn i en analysetabell. I alt ble 168 tekstutdrag analysert. 28 av disse tilhører stortingsmeldingene, mens de resterende 140 ble hentet fra ulike veiledere og retningslinjer fra Helsedirektoratet. Utfordringsbildet er mest konkretisert i stortingsmeldingene, mens dokumentene fra Helsedirektoratet naturlig nok er mer opptatt av å beskrive retningslinjer og organisering av de ulike ordningene.

Alle tekstutdrag ble analysert med utgangspunkt i tre spørsmål:

- Hvilke koordinatorordninger presenteres, og hva kjennetegner disse mht. mål, oppgaver og organisering?

- Hva er problemet: Hvordan forstås samordningsbehov?

- Hvordan ses koordinatorordninger som løsning på samordningsbehov?

Det første spørsmålet hører inn under problemstilling 1 og skal kartlegge helheten og eventuelle variasjoner i beskrivelsene av hva koordinatorordningene er, hvem de refererer til, samt hvilke retningslinjer og organisatoriske rammer som gjelder. De to siste spørsmålene er avledet fra problemstilling 2 og dreier seg om hvilke problemer ordningene er ment 
å løse, og på hvilken måte de forstås som egnet løsning på problemene som beskrives. Det siste steget i analysen sammenfatter alle tre delspørsmålene og tolker tekstutdragene i lys av systemteori.

\section{Teori}

Grunnprinsippet i Luhmanns systemteori (1993) er skillet mellom system og omverden. Verden, som innebærer alt og alle, er så kompleks og uoversiktlig at uten systemer blir en slukt $i$ et hav av muligheter for valg og forbindelser. Systemene reduserer kompleksiteten ved å gjøre valgmulighetene færre - gjennom å trekke en grense mellom seg og sine omgivelser. Forenkling skjer ved at problemer reformuleres gjennom systemenes kommunikative og selvrefererende virkemåte, som vil si at hvert system forstår sine problemer og oppgaver ut fra seg selv (Moe, 1994).

Samordning handler om å håndtere kompleksiteten som oppstår når to eller flere selvrefererende systemer skal virke sammen. En avgjørende faktor for hvordan samordningen skal kunne fungere, er knyttet til hvordan man velger å organisere arbeidsdelingen, eller differensieringen, mellom systemene. Basert på en historisk analyse skiller (Luhmann, 1982) mellom tre konkurrerende former for differensiering: segmentær, hierarkisk og funksjonell. De ulike formene kan sameksistere, men det utvikles alltid en primer differensieringsform som konstituerer det overordnede systemets egenart.

Segmentær differensiering viser til en oppdeling basert på likeartede systemer. En helsetjeneste basert på en segmentær differensiering vil bestå av en rekke allmennpraktiserende helsesystemer med lik kunnskap, som vil kunne behandle samme type lidelser. Standardiserte generalisttilbud som legesenter og helsestasjoner kan være eksempler på segmentær differensiering. Samtidig er det klart at en slik organisering ikke kan være den primære for å håndtere kompleksiteten i et moderne, spesialisert og høyteknologisk helsevesen.

Hierarkisk differensiering innebærer en oppdeling hvor systemene er rangert etter makt og innflytelse. Her reduseres kompleksitet gjennom at de med høyest rang bestemmer hva som er «rett og galt». En helsetjeneste basert på en hierarkisk differensiering vil være preget av en klar lagdeling 
mellom ulike profesjoner og organisatoriske enheter, og arbeidsdelingen styres av de som har mest makt. Hierarkisk differensiering kan langt på vei beskrive legenes posisjon i etterkrigstidens norske helsevesen, og er i litteraturen omtalt som fagstyre (Nordby, 1989; 1993), medikrati (Berg, 2005) og profesjonsstat (Erichsen, 1996).

Funksjonell differensiering viser til en oppdeling basert på systemenes ulike funksjoner. Ifølge Luhmann (1997) kjennetegnes det moderne samfunnet av en slik differensiering, hvor spesialiserte og selvstendige funksjonssystemer som økonomi, juss, politikk, helse og vitenskap ivaretar hver sine oppgaver for samfunnet som helhet. En funksjonelt differensiert helsetjeneste vil bestå av en rekke ulike delsystemer som alle ivaretar sine oppgaver for pasienten og for helsetjenesten som helhet. Differensieringen minsker kompleksiteten for de ulike delsystemene gjennom at hvert system kan konsentrere seg om sitt ansvarsområde, sin ekspertise og sin type helsehjelp. Utdifferensieringen, altså utskillingen av nye delsystemer, gjør helsesystemet i stand til å håndtere stadig mer spesialiserte og komplekse oppgaver. Samtidig øker fragmenteringen og behovet for samordning på tvers av de utdifferensierte systemene. Spesielt viktig blir en slik samordning for pasienter med sammensatte lidelser og behov for hjelp fra ulike delsystemer. I slike tilfeller må systemene kunne kommunisere med hverandre, men kommunikasjon vanskeliggjøres av systemenes interne diskurser. Hvert delsystem forstår sin omverden (pasienter og resten av helsetjenesten) ut fra sin egen funksjon.

Behovet for felles kommunikasjon kan ifølge Luhmann imøtekommes ved å koble kommunikasjonen opp mot generaliserbare medier med et mer entydig språk som flere eller alle systemene forstår (Moe, 1994). Generaliserte medier er basert på samfunnets funksjonssystemer, og eksempler kan være penger, makt, lover, helse og tro. Ut fra kommunikasjonsmediene utvikles det binoere koder som etablerer mening og sammenheng for systemene, for eksempel betale/ikke betale, lovlig/ulovlig, frisk/syk, posisjon/opposisjon, sant/ikke sant. Utfordringen for helsetjenesten er at den er strukturelt koblet til flere funksjonssystemer - som helse, økonomi, politikk, vitenskap og juss - og dermed kan karakteriseres som polyfon (Åkerstrøm, 2002). De mange koblingene utfordrer samordningen ved at det skapes usikkerhet om hvilken kode eller forståelse 
som skal danne grunnlaget for en felles kommunikasjon. Skal beslutninger om samordning være basert på medisinske, juridiske, økonomiske eller politiske kriterier? Gjerde mfl. (2016) viser at den juridiske koden dominerer tildelingskontorenes samordningsfunksjon, og representerer slik et forsøk på å tydeliggjøre beslutningsgrunnlag overfor andre delsystemer og pasienter.

Sentrale spørsmål for å analysere koordinatorordninger er hvordan koordinatorene er tenkt å kunne koble sammen delsystemer, og hvilke koder de forholder seg til når de skal samordne. Ser man på koordinatorordningene som system, vil systemgrensen være basert på koordinering. Alt som omhandler koordinering, får en plass innenfor systemet, mens alt annet tilhører koordinatorsystemets omverden. Samtidig vil systemets selvrefererende virkemåte innebære at grensen som definerer hva koordinering er, vil variere ut fra systemets kontekst. Kontekst kan her være alt fra struktur og kultur til ressurser. Et koordinatorsystem som blir etablert i spesialisthelsetjenesten, vil dermed kunne redusere kompleksiteten på en annen måte enn det et koordinatorsystem i primærhelsetjenesten gjør. Hvordan systemgrensene trekkes, vil altså kunne variere, og flere studier viser til utfordringer, samt hvordan koordinatorer aktivt må jobbe for å etablere sin egen grense i helsetjenesten og gjennom dette redusere kompleksiteten i sin koordineringsfunksjon (Lie mfl., 2018; Melby mfl., 2017; Neal mfl., 1999).

\section{Resultater og drøfting}

\section{Ulike koordinatorordninger}

I styringsdokumentene omtales i alt 14 ulike koordinatorordninger. Ofte benyttes begrepet koordinator generelt uten at det vises til en bestemt ordning, og i noen tilfeller har samme koordinatorordninger ulike benevninger. Eksempelvis kalles koordinatoren i primærhelsetjenesten teamkoordinator, pleiekoordinator og koordinator i forbindelse med individuell plan (IP). Også de koordinerende enhetene har ulike navn, som tildelingskontor og forvaltningskontor. Videre kan koordinatorordningene representere både en rolle, en stillingsprosent og en organisatorisk enhet. 


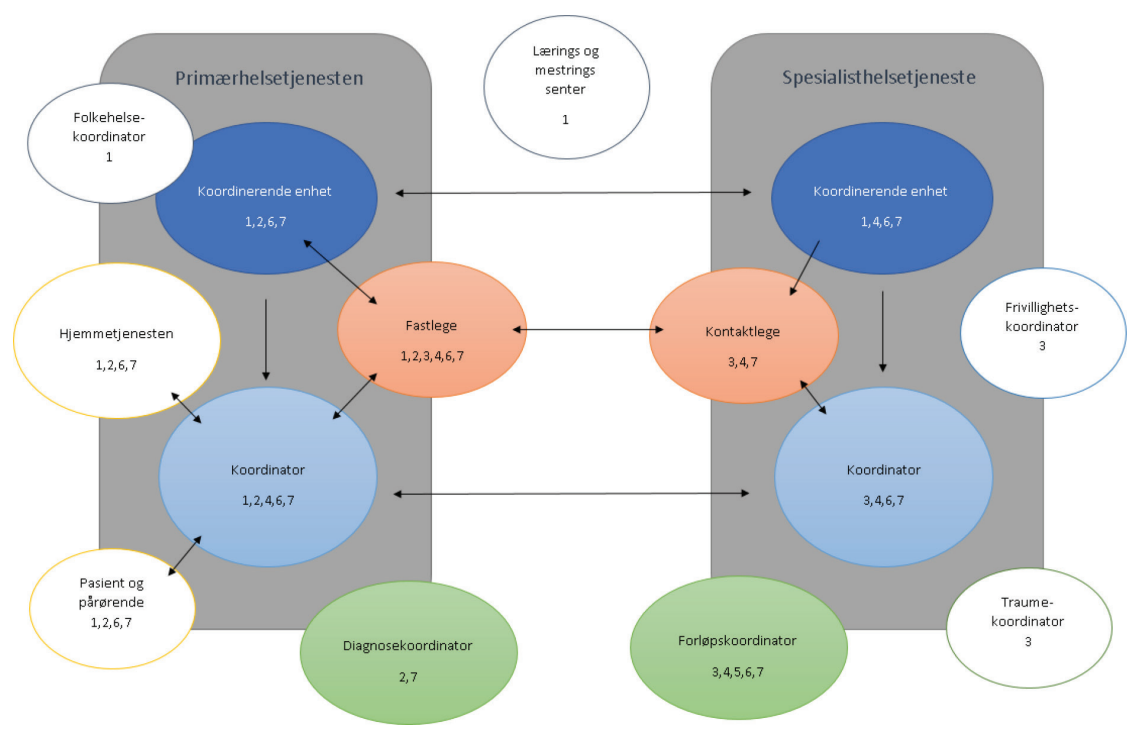

Figur 1. Oversikt over ulike koordinatorordninger

Figuren baserer seg på styringsdokumentenes beskrivelser av koordinatorordninger, og illustrerer mangfoldet i de ulike koordinatorordningene, deres organisatoriske tilknytning og relasjonene dem imellom. Tallene viser til hvilke styringsdokumenter koordinatorordningene er beskrevet i (jf. Tabell 1). Koordinerende enheter og egne koordinatorer finnes både i primærhelsetjenesten og i spesialisthelsetjenesten. Videre finner vi spesifisert diagnose- og forløpskoordinatorer for ulike pasient- og diagnosegrupper, og det medisinskfaglige koordineringsansvaret blir ivaretatt av fastleger og kontaktleger. I styringsdokumentene legges det også vekt på pasient og pårørendes ansvar i koordineringen av eget behandlingsløp. Andre ordninger som tilskrives en viktig koordinerende funksjon, er hjemmetjenesten, folkehelsekoordinator, læring og mestringssentrene, traumekoordinator og frivillighetskoordinator.

Av de 14 koordinatorordningene har vi valgt å se nærmere på, er det åtte som spesielt er rettet mot pasienter med sammensatte behov. Disse ordningene er markert med farger i figur 1. På bakgrunn av fremstillingen i styringsdokumentene har vi sammenfattet informasjon om ordningenes mål, oppgaver og organisering. 


\begin{tabular}{|c|c|c|c|}
\hline Koordinator-ordning & Mål & Oppgaver & Organisering \\
\hline $\begin{array}{l}\text { Koordinerende enhet } \\
\text { i kommune }\end{array}$ & $\begin{array}{l}\text { Sikre helhetlige og } \\
\text { koordinerte tilbud } \\
\text { til pasienter og } \\
\text { brukere med behov } \\
\text { for tjenester fra } \\
\text { flere fagområder, } \\
\text { nivåer og sektorer. }\end{array}$ & $\begin{array}{l}\text { Utvikle rutiner } \\
\text { og møteplasser } \\
\text { for samhandling, } \\
\text { informasjon og } \\
\text { kompetanseutvikling på } \\
\text { tvers av fag, nivåer og } \\
\text { sektorer. } \\
\text { Overordnet ansvar for } \\
\text { tildeling, opplæring } \\
\text { og veiledning av } \\
\text { koordinatorer. }\end{array}$ & $\begin{array}{l}\text { Organisasjonsform } \\
\text { varierer og avgjøres av } \\
\text { den enkelte kommune. } \\
\text { Kan integreres i } \\
\text { allerede etablerte } \\
\text { enheter. }\end{array}$ \\
\hline $\begin{array}{l}\text { Koordinerende } \\
\text { enhet i spesialist- } \\
\text { helsetjenesten }\end{array}$ & $\begin{array}{l}\text { Sikre et helhetlig } \\
\text { tilbud til pasienter } \\
\text { med behov for } \\
\text { habilitering og } \\
\text { rehabilitering. }\end{array}$ & $\begin{array}{l}\text { Bygge faste nettverk } \\
\text { og møteplasser } \\
\text { for samhandling, } \\
\text { informasjon og } \\
\text { kompetanseutvikling } \\
\text { på tvers av } \\
\text { forvaltningsnivåer og } \\
\text { kommunegrenser. } \\
\text { Overordnet ansvar for } \\
\text { tildeling, opplæring } \\
\text { og veiledning av } \\
\text { koordinatorer. }\end{array}$ & $\begin{array}{l}\text { Organisasjonsform } \\
\text { varierer og avgjøres } \\
\text { av det enkelte } \\
\text { helseforetak. } \\
\text { Vanlig at enheten } \\
\text { plasseres i foretakets } \\
\text { samhandlingsavdeling. }\end{array}$ \\
\hline $\begin{array}{l}\text { Koordinator } \\
\text { i kommunen } \\
\text { (Individuell plan) }\end{array}$ & $\begin{array}{l}\text { Sikre at pasient } \\
\text { og bruker får } \\
\text { et helhetlig, } \\
\text { koordinert og } \\
\text { individuelt tilpasset } \\
\text { tjenestetilbud. }\end{array}$ & $\begin{array}{l}\text { Hovedansvar for } \\
\text { oppfølging av bruker. } \\
\text { Sikre felles forståelse } \\
\text { av mål i planprosessen, } \\
\text { initiere, innkalle og } \\
\text { eventuelt lede møter } \\
\text { knyttet til individuell } \\
\text { plan. } \\
\text { Styrke samhandlingen } \\
\text { mellom tjenesteytere på } \\
\text { tvers av fag, nivåer og } \\
\text { sektorer. }\end{array}$ & $\begin{array}{l}\text { Oppnevnes av } \\
\text { koordinerende enhet } \\
\text { i forbindelse med } \\
\text { tildeling av individuell } \\
\text { plan. } \\
\text { En rolle i tillegg til } \\
\text { hovedstilling. }\end{array}$ \\
\hline $\begin{array}{l}\text { Koordinator } \\
\text { i spesialist- } \\
\text { helsetjenesten }\end{array}$ & $\begin{array}{l}\text { Sikre samordning } \\
\text { av tjenestetilbudet } \\
\text { i forbindelse med } \\
\text { institusjonsopphold } \\
\text { og overfor andre } \\
\text { tjenesteytere. }\end{array}$ & $\begin{array}{l}\text { Samhandle med } \\
\text { kontaktlege og } \\
\text { tjenesteytere utenfor } \\
\text { institusjonen. } \\
\text { Sikre fremdrift i arbeidet } \\
\text { med individuell plan } \\
\text { i samarbeid med } \\
\text { koordinator i kommunen. } \\
\text { Sikre overganger etter } \\
\text { utskrivning. }\end{array}$ & $\begin{array}{l}\text { Koordinerende enhet } \\
\text { har ansvar for tildeling, } \\
\text { men i praksis delegert } \\
\text { til pasientansvarlig } \\
\text { avdeling. } \\
\text { Kan både være en rolle } \\
\text { og en stillingsprosent. }\end{array}$ \\
\hline
\end{tabular}




\begin{tabular}{|c|c|c|c|}
\hline Koordinator-ordning & Mål & Oppgaver & Organisering \\
\hline Kontaktlege & $\begin{array}{l}\text { Være } \\
\text { pasientens faste } \\
\text { medisinskfaglige } \\
\text { kontakt } \\
\text { gjennom hele } \\
\text { pasientforløpet. }\end{array}$ & $\begin{array}{l}\text { Være involvert i } \\
\text { behandlingen og } \\
\text { oppfølgingen av } \\
\text { pasienten. } \\
\text { Være tilgjengelig } \\
\text { for pasient og } \\
\text { helsepersonell i } \\
\text { medisinske spørsmål. } \\
\text { Bidra til at } \\
\text { pasientforløpet går som } \\
\text { planlagt. }\end{array}$ & $\begin{array}{l}\text { Det enkelte } \\
\text { helseforetak er } \\
\text { ansvarlig for tildeling } \\
\text { av kontaktlege. } \\
\text { Variasjon både } \\
\text { mellom foretak og } \\
\text { internt på bakgrunn } \\
\text { av ulike avdelingers } \\
\text { innhold og profil. }\end{array}$ \\
\hline Fastlege & $\begin{array}{l}\text { Medisinskfaglig } \\
\text { koordinatoransvar } \\
\text { for pasienter på sin } \\
\text { liste. }\end{array}$ & $\begin{array}{l}\text { Samarbeid med og } \\
\text { henvisning til andre } \\
\text { tjenesteytere. } \\
\text { Informere om og } \\
\text { medvirke til utarbeidelse } \\
\text { av individuell plan. } \\
\text { Koordinerer etter at } \\
\text { pasienten er skrevet ut } \\
\text { fra sykehus og mellom } \\
\text { sykehusopphold } \\
\end{array}$ & $\begin{array}{l}\text { Hovedsakelig private } \\
\text { næringsdrivende. } \\
\text { Finnes enkelte } \\
\text { kommunale } \\
\text { legesentre. }\end{array}$ \\
\hline Forløps-koordinator & $\begin{array}{l}\text { Sikre } \\
\text { sammenhengende } \\
\text { aktiviteter i hele } \\
\text { pakkeforløpet. }\end{array}$ & $\begin{array}{l}\text { Ansvar for utredning, } \\
\text { initial behandling og } \\
\text { oppfølging. } \\
\text { Sikre effektiv utnyttelse } \\
\text { av tilgjengelig kapasitet. } \\
\text { Være representert } \\
\text { i teammøter for å } \\
\text { sikre kontinuitet i } \\
\text { pakkeforløpet. }\end{array}$ & $\begin{array}{l}\text { Organisert gjennom } \\
\text { sykehusene og } \\
\text { standardisert gjennom } \\
\text { ulike pakkeforløp. }\end{array}$ \\
\hline $\begin{array}{l}\text { Diagnose- } \\
\text { koordinator }^{2}\end{array}$ & $\begin{array}{l}\text { Ansvar for å } \\
\text { samordne tilbud } \\
\text { og tjenester til } \\
\text { kreftpasienter i } \\
\text { kommunen. }\end{array}$ & $\begin{array}{l}\text { Skal være lett tilgjengelig } \\
\text { for pasienter og } \\
\text { pårørende. } \\
\text { Skal bidra til gode } \\
\text { rutiner og systemer } \\
\text { for kreftomsorg i } \\
\text { kommunene. }\end{array}$ & $\begin{array}{l}\text { Organisert gjennom } \\
\text { kommunene } \\
\text { med støtte fra } \\
\text { Kreftforeningen. } \\
\text { Kan også ivareta } \\
\text { den lovpålagte } \\
\text { koordinatorrollen. }\end{array}$ \\
\hline
\end{tabular}

Tabell 2. Oversikt over koordinatorordninger for pasienter med sammensatte behov

Tabellen viser at de åtte koordinatorordningene fordeler seg likt mellom forvaltningsnivåene og har en klar parallellitet. De fire ordningene i spesialisthelsetjenesten er koordinerende enhet, koordinator, kontaktlege og forløpskoordinator. Tilsvarende finner vi koordinerende enhet,

2 Her eksemplifisert med kreftkoordinatoren. Andre eksempler på kommunale diagnosekoordinatorer er blant annet demenskoordinator og palliativ koordinator (Helsedirektoratet, 2018c). 
koordinator, fastlege og kreftkoordinator på kommunalt nivå. Videre er målbeskrivelsene (i konsentrert form) til forveksling like. Det dreier seg om å sikre helhet i tilbudene samt være kontaktpunkt for pasienter. Koordinatorordningenes oppgaver er i all hovedsak beskrevet i et «tilretteleggingsspråk», der det dreier seg om å være bindeledd og håndtere kontaktbehov mellom ulike deler av hjelpeapparatet. I tillegg ligger det en oppgave i å forvalte ordningene gjennom oppnevning og opplæring av koordinatorer. Bare for kontakt- og fastlege er koordineringsoppgavene koblet spesifikt til et medisinsk behandlingsansvar for pasienten. Når det gjelder organisering, er hovedbildet at nasjonale myndigheter har overlatt til henholdsvis helseforetak og kommuner å bestemme plassering og konkret utforming.

\section{Hvordan forstås samordningsbehov?}

Stortingsmeldingene Samhandlingsreformen (2008-2009) og Fremtidens primærhelsetjeneste (2014-2015) peker på fragmentering og spesialisering som de grunnleggende faktorene som skaper behov for samordning:

Det er i dag få systemer som er rettet inn mot helheten i de tjenester som skal svare på pasientenes behov for koordinerte tjenester. Derimot har vi mange systemer som er rettet inn mot de ulike deltjenestene, herunder oppdelinger i ulike organisatoriske enheter, separate rettighets-, finansierings- og IKT-systemer. (Helse- og omsorgsdepartementet, 2008, s. 13)

Tjenestene [i dagens helse- og omsorgstjeneste] er siloorganisert og ses ikke i sammenheng som en nødvendig helhet. [Også] nye tjenester etableres atskilt fra eksisterende tjenester, og fragmenteringen forsterkes av at tjenestene gjerne holder til fysisk atskilt i hver sine bygg, med få eller ingen formelle møtearenaer. (Helse- og omsorgsdepartementet, 2015, s. 16)

For pasienter med behov for langvarige og koordinerte tjenester innebærer denne oppsplittingen at tjenester oppfattes som lite tilgjengelige og helhetlige (Helse- og omsorgsdepartementet, 2008; Helse- og omsorgsdepartementet, 2015). Veilederen om oppfølging av personer med store og sammensatte behov (2018b) viser til den samme problematikken: Tjenesteytere jobber hver for seg og ofte monofaglig. Det oppstår 
barrierer når bidrag fra ulike aktører skal virke sammen til en helhet. Videre påpekes det at kompleksiteten i stor grad kan tilskrives de faglige, administrative og organisatoriske ulikhetene. Siloorganiserte og fragmenterte tjenester gir manglende kontinuitet og informasjonsflyt, og pasientene mangler et bestemt kontaktpunkt. Helsedirektoratets veileder for oppfølging av personer med store og sammensatte behov gir følgende situasjonsbeskrivelse:

Økende spesialisering og «silo-organisering» av tjenester kan ha bidratt til fragmentering av tjenestetilbudet både i kommuner og i spesialisthelsetjenesten. De som trenger bred faglig tilnærming må forholde seg til et økende antall tjenesteytere. Dermed øker også behovet for koordinering ved at bidrag fra mange aktører må ses i sammenheng og organiseres på en strukturert måte rundt den enkelte. (Helsedirektoratet, 2018b, s. 8)

Samlet sett må problembeskrivelsene i styringsdokumentene kunne karakteriseres som unisone: Organisatorisk og faglige fragmentering fører til mangelfull samordning mellom ulike aktører i helsetjenesten. Resultatet er at pasienter mangler et bestemt kontaktpunkt, og tjenestene oppleves som lite tilgjengelige og helhetlige.

I lys av systemteori er utfordringene som beskrives, et resultat av helsetjenestens funksjonelle differensiering. Fragmenteringen viser til det store antallet utdifferensierte delsystemer i helsetjenesten, og delsystemenes grenser og selvrefererende virkemåte forhindrer at delsystemenes ulike funksjoner kan virke sammen. Helheten som etterlyses i dokumentene, er de ulike delsystemenes omgivelser, og representerer den kompleksiteten som delsystemene nettopp stenger ute for å kunne opprettholde sin funksjon.

\section{Koordinatorordninger som løsning}

På samme måte som dokumentene har en samstemt beskrivelse av fragmentering som årsak til samordningsbehov, formidler de en tro på at koordinatorordninger kan bidra til en løsning. I 19 av tekstutdragene står det eksplisitt at koordinator skal jobbe for å sikre samordning/ 
koordinering/sammenheng i tjenestene til pasienter med sammensatte behov. Her er tre eksempler:

Koordinator er en viktig person for brukerne for å sikre at tjenestene blir samordnet og tilpasset den enkeltes behov, og for at brukermedvirkning blir ivaretatt gjennom forløpet. (Helse- og omsorgsdepartementet, 2014, s. 108)

Koordinerende enhet for habilitering og rehabilitering har en sentral rolle i å tilrettelegge for gode overganger. Individuell plan og koordinator er gode verktøy for å sikre overganger. Overgangene kan noen ganger innebære bytte av koordinator. God overlapping mellom koordinatorene bør være etablert praksis. Overføring av informasjon bør skje både gjennom dokumentasjon og planmøter. (Helsedirektoratet, 2018b, s. 49).

I spesialisthelsetjenesten er det i forbindelse med innføringen av pakkeforløp etablert en ordning med forløpskoordinatorer. Disse personene skal sikre sammenhengende aktiviteter i hele pakkeforløpet. Det vil si utredning, behandling og oppfølging uten unødig ikke-medisinsk begrunnet ventetid (Helsedirektoratet, 2018c, s. 93).

Tabell 1 viser at det sentrale målet for koordinatorordningene er å sikre koordinert oppgavefordeling mellom de ulike delsystemene i helsetjenesten. Målet er altså ikke primært å bryte ned grensene i helsetjenesten, men å håndtere grenser ved å være bindeledd mellom delsystemer. I lys av systemteori er det et paradoks å etablere samordningstiltak som opprettholder den funksjonelle differensieringen som blir beskrevet som hovedutfordringen for å oppnå samordning.

Til tross for det paradoksale i at man utdifferensierer et nytt delsystem som svar på differensieringsproblemer, kan en slik løsning gi lokale reduksjoner av kompleksitet. Krav om samordning flyttes fra de andre delsystemene til koordinatorsystemet. Flyttingen kan medføre minsket kompleksitet for pasientene, som kan forholde seg til ett system og ett kontaktpunkt. Samtidig forenkles situasjonen i de andre delsystemene i helsetjenesten ved at de i mindre grad må forholde seg til den kompleksiteten som krav om samordning med andre delsystemer innebærer. Nordsveen og Andershed (2015) viser hvordan koordinatoren letter sykepleiernes arbeid ved å fungere som en kontaktperson som formidler informasjon de selv tidligere måtte ta ansvar for. Koordinatorene 
bidro til at sykepleierne brukte mindre tid på å finne riktig person, det oppstod færre misforståelser, og sykepleierne kunne bruke mer tid sammen med pasienten. Innføringen av koordinatorordninger legger slik til rette for at andre delsystemer kan fokusere på sitt eget ansvarsområde. I sin ytterste konsekvens kan dette bidra til å forsterke differensieringen og grensene mellom delsystemer ved at ekstern kontakt går via koordinator.

Gjerde mfl. (2016) illustrerer poenget med forsterket differensiering gjennom sin studie av kommunale tildelingskontorer. Disse kontorene er kontaktledd til sykehuset når det gjelder utskrivningsklare pasienter, og representerer en sentral «koblingsboks» både mellom sykehuset og det kommunale tjenestetilbudet og horisontalt i kommunen. Utdifferensiering av et eget koordineringssystem - i form av et tildelingskontor - har på den ene siden avlastet profesjonene i praksisfeltet når det gjelder å ta ansvar for koordinering av tjenester. På den andre siden viser studien at man har mistet kollegiale og helsefaglige beslutningsarenaer innad i den enkelte kommune og i relasjonen mellom kommuner og sykehus. Både vertikal og horisontal kontakt går via kontoret, og i mindre grad mellom de som jobber i det operative feltet. Tildelingskontorenes arbeid skjer innenfor et byråkratisk rammeverk med vekt på at beslutningene skal være juridisk korrekte, dvs. at man bruker juridisk kode.

Vi tolker styringsdokumentenes argumentasjon som et uttrykk for at koordinatorordninger heller forstås som en måte å håndtere kompleksitet på, enn som strategier som direkte forsøker å endre systemenes manglende evne til felles kommunikasjon og handling. Men bildet er ikke helt entydig. Vi finner også eksempler på at koordinatorordningene skal bidra til å redusere eksisterende differensiering ved å utvikle rutiner og arenaer for samarbeid samt arbeide for tverrfaglighet og en felles forståelse av pasientens behov. Denne typen forventninger er spesielt aktuelle for koordinerende enheter og diagnosekoordinator, dvs. ordninger som primært arbeider på et overordnet og administrativt nivå, men de uttrykkes også i noen tilfeller for de pasientorienterte koordinatorordningene: 
Koordinator skal sikre felles forståelse av målene i planprosessen. (Helsedirektoratet, 2018c, s. 91)

Felles kompetansetiltak og veiledning på tvers av enheter, felles rutiner for tverrfaglig samarbeid og møteplasser for å utvikle felles «kultur» er viktige tiltak for å bygge ned «siloer». Koordinatoropplæring med deltakelse på tvers av fag, nivåer og sektorer er ett eksempel på slike tiltak. (Helsedirektoratet, 2018b, s. 30)

[De koordinerende] enhetene i helseforetak og kommuner bør være pådrivere for utvikling av felles kunnskap og god samarbeidskultur i arbeidet med individuell plan. (Helsedirektoratet, 2018c, s. 73)

Samlet sett fremstår argumentasjonen som noe uklar. På den ene siden argumenteres det for å etablere egne koordinatorordninger som skal ha ansvaret for å samordne de ulike delsystemene, mens det på den andre siden uttrykkes forventninger om at koordinatorene skal arbeide for en mer dedifferensiert helsetjeneste. Her kiles det inn et nytt system som reduserer de andre systemenes samordningskompleksitet, samtidig som det uttrykkes et ønske om at koordinatorordningen skal inkludere delsystemene i den samme kompleksiteten. Sett fra delsystemenes side er en av gevinstene med koordinatorordningene nettopp at de representerer en buffer som skjermer dem for direkte krav om å ta ansvar for koordineringen.

\section{En funksjonelt differensiert koordinatorordning}

Samhandlingsreformen fremhever at både nye og gamle samordningstiltak må utvikle felles forståelse og felles mål:

Skal summen av gamle og nye tiltak gi de tilsiktede effektene for bedre samhandling er det avgjørende at det innenfor helse- og omsorgstjenesten utvikler seg en faglig og organisatorisk kultur, der de ulike faglige aktørene og organisatoriske enhetene i større grad ser sine egne tjenester som en del av et samlet pasientforløp. Mer konkret betyr dette at aktørene må utvikle felles forståelse av hva som er gode pasientforløp for de ulike pasientgruppene og for den enkelte 
pasient, og samles om felles mål for behandlingen. (Helse- og omsorgsdepartementet, 2008, s. 48)

Tabell 1 viser at helhet og felles forståelse trekkes frem som viktig for både mål og oppgaver. I lys av systemteori kan man argumentere for at koordinatorordningene kunne ha dannet grunnlag for felles forståelse og mål for koordineringen dersom koordinatorsystemet var et overordnet samordningstiltak. Med overordnet menes det at ordningen kan operere uavhengig av den eksisterende differensieringen i helsetjenesten. Altså at koordinatorsystemet har myndighet og mandat til å håndtere koordinering av pasientbehandling på tvers av forvaltningsnivåer, organisatoriske og profesjonelle grenser. Et overordnet koordinatorsystem som hadde koblet beslutninger og kommunikasjon om samordning opp mot ett funksjonssystem og én kode, kunne altså ha bidratt til en felles forståelse av koordinering i helsetjenesten.

Ser vi på antallet koordinatorordninger og hvordan de er organisert, tyder det derimot på at de langt på vei adopterer den funksjonelle differensieringen som allerede kjennetegner helsetjenesten. Figur 1 illustrerer hvordan koordinatorordningene gjenspeiler helsetjenestens organisering på forvaltningsnivå, i faglige spesialiseringer og enheter. Istedenfor å etablerere et overordnet koordinatorsystem med ansvar for samordning på tvers av delsystemene, er det delsystemene selv som har fått ansvar for å utdifferensiere koordinatorsystemene. Resultatet er en rekke ulike koordinatorer som har ansvaret for koordinering i sine respektive deler av helsetjenesten.

Tabell 1 viser at helseforetak, kommuner og sykehus har stor frihet til å organisere ordningene slik de ønsker, så lenge den lovpålagte koordinatorfunksjonen opprettholdes. At koordinatorordningene utdifferensieres fra delsystemene i helsetjenesten, innebærer at de yter sin koordineringsfunksjon med utgangspunkt i de ulike delsystemenes interne logikker og forståelser. Koordinatorene bidrar ikke da til å skape en felles forståelse og kultur i helsetjenesten; de kan snarere videreføre og forsterke de forskjellene som allerede finnes. Vi oppfatter denne potensielle forsterkningen som vårt andre paradoks. En slik oppfatning er heller ikke fremmed for nasjonale myndigheter. I primærhelsemeldingen uttrykkes 
en bekymring for at koordinatorordningene faktisk kan forsterke fragmenteringen i helsevesenet:

Desto flere særlige team og koordinatorordninger man etablerer for særlige brukergrupper (f.eks. kreft, palliasjon, demens), desto mer løftes kompetansen og ansvaret ut av de ordinære tjenestene, og faren for fragmentering og koordineringsproblemer øker. (St.meld. nr. 26 (2014-2015), s. 48)

Avila mfl. (2016) bekrefter at en sementering av systemgrenser ved hjelp av flere koordinatorer per forløp oppleves å fungere godt. De enkelte koordinatorene har oversikt over sin avdeling. Dersom de skulle «blande seg inn» i andre avdelinger, ville det kunne skape kaos for dem som ikke er involvert med akkurat deres pasient. På samme vis som i Nordsveen og Andersheds (2015) studie beskrives her det paradoksale som noe positivt: Det er bra at ulike koordinatorer skjermer avdelinger og ansatte mot å måtte forholde seg til hverandre. Igjen ser vi hvordan koordinatorordningene reduserer kompleksiteten for delsystemene gjennom å opprettholde grensene og den funksjonelle differensieringen i helsetjenesten.

\section{Koordinering av koordinatorer}

Den funksjonelle differensieringen av både helsetjenesten og koordinatorordningen fører oss videre til det tredje paradokset. Med de mange koordinatorordningene som finnes, er det i dag ikke bare behov for å koordinere profesjoner og organisatoriske enheter. Det oppstår i tillegg et behov for koordinering av koordinatorene. Styringsdokumentene gir en rekke eksempler på denne type koordineringsbehov og ambisjoner:

Koordinerende enheter i helseforetak og kommuner er faste gjensidige kontaktpunkt for tverrfaglig samarbeid. Samarbeidet bør omfatte informasjonsutveksling, kompetanseutvikling og dialog om sentrale utviklingsområder. (Helsedirektoratet, 2018c, s. 74) 
Koordinator og kontaktlege må opptre samlet og godt koordinert, slik at deres respektive roller fremtrer tydelige for pasient, pårørende og samarbeidspartnere. De må samarbeide om å løse pasientens utfordringer. (Helsedirektoratet, 2016, s. 27)

Koordinering av koordinatorene vil utfordre deres respektive roller og ansvarsområder. Ifølge sammenstillingen i tabell 1 har både mål og oppgaver klare fellestrekk, og ansvarsområdene er i flere tilfeller overlappende. For eksempel har både koordinator i kommunen og koordinator i spesialisthelsetjenesten ansvaret for sammenheng i tjenestetilbudet til pasienter som beveger seg mellom forvaltningsnivåene. Om de kommunale koordinatorene står følgende å lese:

Koordinatoren skal sørge for nødvendig oppfølging av den enkelte pasient eller bruker. Koordinator skal også sikre samordning av tjenestetilbudet og fremdrift i arbeidet med individuell plan. (Helsedirektoratet, 2018c, s. 91)

Mens det for koordinatorene i spesialisthelsetjenesten står:

I og med at koordinator i forbindelse med individuell plan i de fleste tilfeller oppnevnes i kommunen, blir rollen til koordinator i spesialisthelsetjenesten noe annerledes. Oppgaven til koordinator i spesialisthelsetjenesten innebærer å koordinere internt under oppholdet, og eksternt med de som skal følge opp etter utskrivning. Dersom behovet for kontinuitet og sammenheng i forløpet tilsier det, skal koordinator samhandle med personell og instanser utenfor institusjonen som har eller vil få et behandlings- eller oppfølgingsansvar for pasienten. (Helsedirektoratet, 2018c, s. 92)

Koordinatorene i kommuner og i spesialisthelsetjenesten skal altså samordne tjenestetilbudet, og samtidig har fastlegen det medisinskfaglige koordineringsansvaret til pasientene på sin liste. Et medisinskfaglig koordineringsansvar har også kontaktlegen i spesialisthelsetjenesten. Skillet mellom en kontaktlege og en koordinator i spesialisthelsetjenesten beskrives på følgende måte: «Henvendelser og kontakt med annet helsepersonell om saker av medisinskfaglig karakter håndteres av 
kontaktlegen. Praktisk tilrettelegging og samordning av ulike tilbud ivaretas av koordinator» (Helsedirektoratet, 2018c).

Så kan man spørre seg om ikke den praktiske tilretteleggingen og samordningen av ulike tilbud også har elementer av medisinskfaglige karakter? I lys av Luhmann viser sitatet til at kontaktlegen skal koordinere ut fra en medisinsk kode (syk/frisk) og ta utgangspunkt i diagnoser og behandling, mens koordinatoren skal benytte en annen kode, muligens avledet fra logistikk (økonomi). Samtidig er det lovfestet at personell i spesialisthelsetjenesten som er oppnevnt som koordinatorer, utfører helsehjelp når de utøver koordinatorrollen (Helsedirektoratet, 2018c). Koordinatorene utfører altså helsehjelp, men det er kontaktlegen som skal ta seg av den medisinskfaglige koordineringen. Distinksjonen mellom de to koordinatorordningene kan virke noe uklar, og ansvarsfordelingen og hvordan de to ordningene skal samordnes, beskrives på følgende måte:

Koordinator skal medvirke til at informasjon av betydning for behandlingen videreformidles til kontaktlegen, og kontaktlegen skal være oppmerksom på å holde koordinator orientert om forhold av betydning for planlegging av tjenestetilbudene. (Helsedirektoratet, 2018c, s. 93)

Kontaktlegen har det medisinskfaglige koordineringsansvaret for sine pasienter på sykehuset, mens fastlegen har det samme ansvaret for pasienter på sin liste:

Kontaktlegen er i dialog med fastlegen i medisinske spørsmål, mens koordinator er i dialog med koordinator i kommunen om praktiske spørsmål og med andre tjenesteytere, etater og institusjoner om forhold der det er aktuelt å samordne tjenester. (Helsedirektoratet, 2018c, 93)

Rent prinsipielt synes det å være ryddig at ansvarsfordelingen følger forvaltningsnivåene, men de multisyke pasientene beveger seg jo nettopp mellom nivåene. Her ligger det paradoksale i å adoptere helsetjenestens funksjonelle differensiering i organiseringen av koordinatorordningene, ved at det oppstår nye grenser og spesialiseringer også for det å utøve koordinatorfunksjonen. Dette tydeliggjøres også i beskrivelsene av forholdet mellom forløpskoordinator og koordinator: 
Begge koordinerer helsetjenester for pasienten. Et pakkeforløp for kreft omfatter hele pasientforløpet, men ofte vil arbeidsopppgavene for forløpskoordinator være konsentrert om perioden frem mot behandlingsstart. Koordinator i sykehus har sine oppgaver i perioden pasienten er under behandling eller oppfølging i spesialisthelsetjenesten. (Helsedirektoratet, 2016, s. 27-28)

Avila mfl. (2016) viser til at ansvarsdelingen og overgangen mellom disse ordningene kan være vanskelig, noe som spesielt er knyttet til at forløpskoordinatorens funksjon avsluttes ved behandlingsstart. Melby mfl. (2017) rapporterer at samarbeidet mellom fastlegen, forløpskoordinatoren og kreftkoordinatorene også kunne være utfordrende.

\section{Tre mulige paradokser}

Utgangspunktet for dette kapittelet er behovet for økt innsikt i koordineringsordninger som samordningstiltak. Gjennomgangen av styringsdokumenter for perioden 2008-2018 avdekket i alt 14 ulike koordinatorordninger i helsetjenesten. Av disse var åtte mer spesifikt rettet mot pasienter med sammensatte behov, og vi har beskrevet disse med henblikk på mål, oppgaver og organisering. Målene går ut på å sikre pasientenes behov for helhetlige tilbud, og ordlyden er til forveksling lik for de ulike ordningene. Når det gjelder beskrivelse av oppgaver, gjenbrukes mange av begrepene i målformuleringene. Det er snakk om å ivareta relasjoner på tvers av fag, forvaltningsnivåer og enheter - til beste for pasienten. I tillegg nevnes mer spesifikke prosessrelaterte oppgaver, medisinskfaglig ansvar og opplæring av koordinatorer. Nasjonale myndigheter har i hovedsak overlatt til den enkelte kommune eller det enkelte helseforetak å bestemme hvordan koordinatorordningene skal organiseres.

Problembeskrivelsene som kommer til uttrykk i styringsdokumentene, peker på at organisatorisk og faglig fragmentering gir dårlige kår for helhetlig hjelp til pasienter med sammensatte behov. Koordinatorordninger representerer en løsning gjennom å være koblingsledd vertikalt og/eller horisontalt til beste for pasienten. Ved å tolke funn fra arbeidet med de to første problemstillingene i lys av Luhmanns systemteori har vi avdekket tre mulige paradokser ved koordinatorordninger i en funksjonelt 
differensiert helsetjeneste. Paradoksene bygger på hverandre og er til dels overlappende. Samtidig tar de for seg ulike aspekter ved ambisjonen om at koordinatorordninger skal løse samordningsutfordringene som den funksjonelle differensieringen har skapt.

Paradoks 1: Funksjonell differensiering beskrives som hovedutfordringen for å oppnå samordning - koordinatorordninger bevarer den funksjonelle differensieringen heller enn å redusere den.

Det første paradokset tar utgangspunkt i styringsdokumentenes beskrivelse av at den funksjonelle differensieringen i helsetjenesten representerer en hovedutfordring når det gjelder å oppnå samordning. Det paradoksale er at koordinatorordninger som samordningstiltak i liten grad bidrar dedifferensierende. Fremfor å bryte ned profesjonelle og organisatoriske grenser er koordinatorordningene primært opptatt av å håndtere disse.

Paradoks 2: Organiseringen av koordinatorordningene adopterer og forsterker helsetjenestens funksjonelle differensiering.

Mens det første paradokset er knyttet til valg av koordinatorordninger som samordningstiltak, dreier det andre seg om hvordan ordningene blir organisert. En forankring av koordinatorordningene i eksisterende delsystemer gjør at det som skal være løsningen, baserer seg på problemet. Gjennom å gi delsystemene ansvar og frihet til å velge hvordan koordinatorordningene skal organiseres, reproduseres fragmentering og manglende helhetsforståelse. Slik blir koordinatorordningene en forlengelse av den eksisterende differensieringen.

Paradoks 3: Etablering av koordinatorordninger bidrar $i$ seg selv til å øke samordningskompleksiteten ved at man i tillegg må koordinere koordinatorene.

Det tredje paradokset viser til at etableringen av en rekke ulike koordinatorer fører til at man ikke bare må koordinere de organisatoriske og profesjonelle delsystemene, man får også et behov for å koordinere koordinatorsystemene. At koordinatorene får ansvar for koordinering, kan 
også forsterke systemgrensen i helsetjenesten gjennom at delsystemene slipper å forholde seg til den kompleksiteten som samordning med andre delsystemer medfører. Paradokset forsterker bildet av løsninger som ikke bare flytter kompleksiteten fra delsystemer til koordinatorordninger, men som også totalt sett øker den.

\section{Oppsummering}

Vårt bidrag baserer seg på dokumentanalyse og kan kun i beskjeden grad belyse hvordan koordinatorordningene fungerer i praksis. De paradoksene og utfordringene vi peker på, er knyttet opp mot styringsdokumentenes beskrivelse av samordningsbehov og mulige løsninger. Hvordan koordinatorene fungerer i praksis, er et annet spørsmål. Vi ser imidlertid at de enkeltstudier som finnes, bekrefter vår analyse og tolkning. Flere studier viser at koordinatorene fungerer godt nettopp fordi de opprettholder den funksjonelle differensieringen, og flytter kompleksitet fra profesjoner og pasienter og inn i nye systemer. Det er altså koordinatorene sett i forhold til problembeskrivelsen som er paradoksal, og ikke nødvendigvis koordinatorordningene i seg selv.

Koordinatorordningenes utbredelse og myndighetenes tiltro til denne type samordningstiltak kan tolkes som et behov for å vise handlekraft gjennom å etablere ordninger som per definisjon signaliserer at en gjør noe med fragmenteringen i helsetjenesten. Ordningene assosieres med ord som tilrettelegger, formidler og bindeledd, og kan tenkes å ha en symbolsk verdi uavhengig av hvordan de fungerer i praksis. Vår gjennomgang tyder på at ordningene også burde omtales som buffere, portvakter og systembevarere. En videre empirisk utforskning bør ikke avgrenses til å studere ulike koordinatorordningers virkemåte, men ha ambisjoner om å belyse hvilke konsekvenser de har for pasientene og helsetjenesten som helhet.

\section{Referanser}

Ahgren, B. (2014). The path to integrated healthcare: Various Scandinavian strategies. International Journal of Care Coordination, 17(1-2), 52-58. https://doi. org/10.1177/2053435414540606 
Andersson, J., Ahgren, B., Axelsson, S.B., Eriksson, A. \& Axelsson, R. (2011). Organizational approaches to collaboration in vocational rehabilitation-an international literature review. International Journal of Integrated Care, 11(4). https://doi.org/10.5334/ijic.670

Avila, H., Deglum, T.R.M., Eide, M.A. \& Vaage, L.U. (2016). Pakkeforløp for kreft.

Berg, O. (2005). Fra politikk til økonomikk. Den norske helsepolitikks utvikling det siste sekel. Oslo: Den norske lægeforening skriftserie.

Bouckaert, G., Peters, B.G. \& Verhoest, K. (2010). The coordination of public sector organizations. Shifting patterns of public administration. Houndmills, Basingstoke: Palgrave Macmillan.

Erichsen, V. (1996). Reformer i helsetjenesten: «Profesjonsstatens» sammenbrudd? I O. Lian (Red.), Helsetjenesten i samfunnsvitenskapens lys. Oslo: Tano Aschehoug.

Gjerde, I., Torsteinsen, H. \& Aarseth, T. (2016). 4 Tildelingskontoret - en innovasjon i norske kommuner? Offentleg sektor i endring (s. 48-64).

Hagen, R. \& Johnsen, E. (2013). Styring gjennom samhandling: Samhandlingsreformen som kasus. I A. Tjora \& L. Melby (Red.), Samhandling for helse (s. 31-53). Oslo: Gyldendal Akademisk.

Helsedirektoratet. (2016). Kontaktlege i spesialisthelsetjenesten. Hentet fra: https:// helsedirektoratet.no/Lists/Publikasjoner/Attachments/1197/Veileder-kontaktlegei-spesialisthelsetjenesten.pdf.

Helsedirektoratet (2018a). Pakkeforløp for kreft - Generell informasjon for alle pakkeforløpene for kreft. Hentet fra: https://helsedirektoratet.no/retningslinjer/ pakkeforlop-for-kreft-generell-informasjon-for-alle-pakkeforlopene-for-kreft/ seksjon?Tittel=pakkeforlop-pa-kreftomradet-1375

Helsedirektoratet (2018b). Veileder om oppfølging av personer med store og sammensatte behov. Hentet fra: https://helsedirektoratet.no/Retningslinjer/ Oppf\%C3\%B8lging\%2oav\%2opersoner\%2omed\%2ostore\%20og\%2O sammensatte\%2obehov.pdf

Helsedirektoratet (2018c). Veileder om rehabilitering, habilitering, individuell plan og koordinator. Hentet fra: https://www.regjeringen. no/contentassets/7b6ad7eoefia403d97958bcb344786o9/no/pdfs/ stm2015201600110oodddpdfs.pdf

Helse- og omsorgsdepartementet (2008). Samhandlingsreformen. Rett behandling - på rett sted - til rett tid (St.meld. nr. 47 (2008-2009)). Oslo: Helse- og omsorgsdepartementet.

Helse- og omsorgsdepartementet (2014). Fremtidens primorhelsetjeneste - næerhet og helhet (St.meld. nr. 26 (2014-2015)). Oslo: Helse- og omsorgsdepartementet.

Helse- og omsorgsdepartementet (2015). Nasjonal helse- og sykehusplan 2016-2019 (St.meld. nr. 11 (2015-2016)). Oslo: Helse- og omsorgsdepartementet. 
Høyem, A., Gammon, D., Berntsen, G.R. \& Steinsbekk, A. (2018). Policies Make Coherent Care Pathways a Personal Responsibility for Clinicians: A Discourse Analysis of Policy Documents about Coordinators in Hospitals. International journal of integrated care, 18(3). https://doi.org/10.5334/ijic.3617

Kjellevold, A. (2014). Individuell plan i helse- og omsorgstjenesten - behov for endringer og ansvarliggjøring? Tidsskrift for erstatningsrett, forsikringsrett og velferdsrett, 11(04), 267-300.

Lie, N.K., Hauken, M.A. \& Solvang, P.K. (2018). Providing coordinated cancer care - a qualitative study of Norwegian cancer coordinators' experiences of their role. Cancer Nursing. https://doi.org/10.1097/ncc.0000000000000504

Luhmann, N. (1982). The differentiation of society. New York: Columbia University Press.

Luhmann, N. (1993). Sociale systemer : grundrids til en almen teori. København: Munksgaard Bogdisketter.

Luhmann, N. (1997). Die Gesellschaft der Gesellschaft. Frankfurt am Main: Suhrkamp.

Moe, S. (1994). Sosiologi i hundre år. En veileder til sosiologisk teori. Oslo: Universitetsforlaget.

Melby, L., Das, A., Halvorsen, T. \& Steihaug, S. (2017). Evaluering av tjenestetilbudet til personer med behov for lindrende behandling og omsorg. SINTEF. A27799.

Mintzberg, H. (1979). The structuring of organizations. Englewood Cliffs, NJ: Prentice Hall.

Neal, J., Brown, T. \& Rojjanasrirat, W. (1999). Implementation of a case coordinator role: A focused ethnographic study. Journal of Professional Nursing, 15(6), 349-355. https://doi:10.1016/s8755-7223(99)80065-9

Nordby, T. (1989). Karl Evang. En biografi. Oslo: Aschehoug.

Nordby, T. (1993). Det offentlige helsevesenet - en fagstyrets høyborg. I T. Nordby (Red.), Arbeiderpartiet og planstyret 1945-1965. Oslo: Universitetsforlaget.

Nordsveen, H. \& Andershed, B. (2015). Pasienter med kreft i palliativ fase på vei hjem - Sykepleieres erfaringer av samhandling. Nordisk Sygeplejeforskning, 5(3), 239-252.

Paskett, E.D., Harrop, J.P. \& Wells, K.J. (2011). Patient navigation: An update on the state of the science. CA: A Cancer Journal for Clinicians, 61(4), 237-249. https:// doi.org/10.3322/caac.20111

Ramsdal, H. (2019) Tverfaglige team - hvordan lykkes? I C. Bjørkquist, \& M.J. Fineide (Red.), Organisasjonsperspektiv på samordning av helse- og velferdstjenester. Oslo: Cappelen Damm Akademisk.

Sosial- og helsedepartementet (1998). Ansvar og meistring (St.meld. nr. 21 (19981999)). Oslo: Sosial- og helsedepartementet.

Syse, A. \& Moshina, N. (2015). Kreftkoordinatorers rolle i samhandlingsarbeidet i kreftomsorgen i norske kommuner. Nordisk tidsskrift for helseforskning, 11(1), 49-65. https://doi:10.7557/14.3476 
Vik, E. (2018). Helseprofesjoners samhandling-en litteraturstudie. Tidsskrift for velferdsforskning, 21(02), 119-147. https://doi.org/10.18261/issn.2464-3076-2018O2-O3

Walsh, J., Harrison, J.D., Young, J.M., Butow, P.N., Solomon, M.J. \& Masya, L. (2010). What are the current barriers to effective cancer care coordination? A qualitative study. BMC Health Services Research, 10(1), 132. https://doi.org/10.1186/1472-696310-132

Åkerstrøm, N. (2002). Polyfone organisationer. Nordiske Organisasjonsstudier, 4(2), $27-53$. 


\title{
Prosessorienterte modeller - tre organisatoriske utfordringer
}

\section{Mona Jerndahl Fineide}

\author{
Avdeling for helse og velferd, Høgskolen i Østfold
}

\begin{abstract}
Sammendrag: Kapitlet diskuterer hvilke organisatoriske utfordringer som bør håndteres for at prosessorienterte modeller kan bidra til bedre samordning. Behandlingslinjer er et illustrerende eksempel på en slik prosessorientert tilnærming, og det empiriske materialet er hentet fra en studie om innføring av to ulike behandlingslinjer for ADHD. Gjennom å belyse hvordan selve standardiseringsarbeidet ble gjennomført, trekkes det frem tre organisatoriske utfordringer. Den første er anvendelsesområdet for behandlingslinjen. En avgrensing kan bidra til at standardiseringsarbeidet blir utført tett på de som har informasjon om hvilke samordningsutfordringer som må løses. Den andre utfordringen er å anvende hensiktsmessige verktøy og teknikker i standardiseringsarbeidet med henblikk på å finne egnede tiltak for å bedre samordningen. Og den tredje er forberedelse for god implementering, og at det iverksettes kompetansehevende tiltak i samarbeid med de som skal anvende det nye verktøyet. Disse tre utfordringene er alle sentrale i standardiseringsarbeidet, og bør håndteres for at prosessorienterte modeller kan bidra til bedre samordning.
\end{abstract}

Nøkkelord: prosessorienterte modeller, pakkeforløp, standardisering, organisering

\section{Introduksjon}

Prosessorienterte modeller i helse- og velfredssektoren betegnes ofte som behandlingslinjer, pakkeforløp eller pasientforløp. De ulike modellene kan romme alt fra velavgrensede prosedyrer som gjelder behandling av en enkelt diagnose, til omfattende samhandlingsprosesser mellom store deler av helse- og velferdstjenestene. Her handler det ikke om den enkelte prosedyrestandard, men om et helt sett av standarder som er satt sammen i en

Sitering av dette kapitlet: Jerndahl Fineide, M. (2019). Prosessorienterte modeller - tre organisatoriske utfordringer. I C. Bjørkquist \& M. Jerndahl Fineide (Red.), Organisasjonsperspektiv på samordning av helse- og velferdstjenester (s. 145-167). Oslo: Cappelen Damm Akademisk. https://doi.org/10.23865/noasp.66.ch6.

Lisens: CC BY 4.0 
kjede for å beskrive hvordan aktørene, oftest profesjonsutøvere, skal utføre sin del av arbeidsprosessen. Modellene benytter IT-baserte systemer som visualiserer hvert enkelt steg i arbeidsprosessen ned på flytskjemanivå, og det legges inn detaljerte aktivitetsbeskrivelser som viser fremgangsmåten i behandlingen av de ulike arbeidsoppgavene. Utviklingen av slike prosessorienterte modeller representerer en tung idéstrømning i organisasjonstenkningen (Røvik, 2016, s. 182). I tillegg kan denne tilnærmingen betraktes som en premissleverandør for samhandling i helse- og velferdssektoren og for helse- og velferdspolitiske prioriteringer (Dent, 2008; Fineide \& Ramsdal, 2014; Ramsdal \& Ramsdal, 2009). I dette kapitlet vil jeg diskutere hvilke organisatoriske utfordringer som bør håndteres for at prosessorienterte modeller kan bidra til bedre samordning. Jeg vier spesiell oppmerksomhet til hvordan prosessorienterte modeller - her behandlingslinjer - blir laget, altså hvordan selve standardiseringsprosessen blir gjennomført. Det empiriske grunnlaget er hentet fra to ulike behandlingslinjer: for barn og unge med ADHD og for voksne med ADHD.

Gjennom de siste 10-15 årene har det vært tydelige politiske føringer som angir en ambisjon om at innføring av prosessorienterte modeller skal bidra til å løse kvalitets- og koordineringsproblemer i helse- og velfredssektoren. Samhandlingsreformen, slik den er beskrevet i Stortingsmelding nr. 47 (Helse- og omsorgsdepartementet, 2008) skisserer at gode, helhetlige pasientforløp i større grad bør bli en felles referanseramme for alle aktører i helse- og omsorgstjenesten. For at forløpstankegangen skal bidra til bedre samhandling, pekes det på at spesialisthelsetjenesten bør bevege seg utenfor sine egne enheter: «Et viktig utviklingstiltak må være at spesialisthelsetjenesten utvider perspektivet og i større grad medvirker i utvikling av forløp som går på tvers av tjenesteområder og forvaltningsnivå» (Helse- og omsorgsdepartementet, 2008, s. 112-113). Sitatet over er et uttrykk for en klar forventning om at spesialisthelsetjenesten trekker kommunene og andre aktører, for eksempel fastlegene, inn i et samarbeid om å utvikle prosessorienterte modeller. Nasjonal helse- og sykehusplan for 2016-2019 uttrykker følgende problemformulering og ambisjoner:

Stor variasjon i forbruket av spesialisthelsetjenester kan være en indikasjon på kvalitetssvikt og innebære en fare for pasientsikkerheten. Variasjon kan være uttrykk for underbehandling, overbehandling eller feilbehandling. 
Standardisering av pasientforløp, med utgangspunkt i oppsummert kunnskap og faglige retningslinjer, er viktig for et godt behandlingsresultat, for god utnyttelse av kompetanse og ressurser i sykehusene, og ikke minst for å sikre pasientene helhet, kvalitet og sammenheng. (Helse- og omsorgsdepartementet, 2015, s. 34)

Som nevnt er det selve standardiseringsarbeidet (produksjonen) av prosessorienterte modeller dette kapitlet dreier seg om. Første del tar for seg hvordan standardisering av arbeidsprosesser kan forstås som former for regulering i vid forstand, deretter vil jeg presentere metoden som er anvendt. Tredje del belyser hvordan standardiseringsarbeidet ble gjennomført da de to ulike behandlingslinjene for ADHD ble produsert. Fjerde del diskuterer tre mulige organisatoriske utfordringer som bør håndteres, og i siste del oppsummeres kapitlet.

\section{Standardisering er regulering i vid forstand}

Prosessorienterte modeller angir prosedyrer for hvordan arbeidsprosesser skal utføres: De er standardiserte. I tråd med Mintzbergs (1983) tese er utvikling og bruk av standarder en viktig koordineringsmekanisme når det finnes høy grad av arbeidsdeling og spesialisering i og mellom organisasjoner. Man kan oppnå økt forutsigbarhet og kontroll med arbeidsprosessene, noe som er viktig for å redusere forskjellsbehandling av pasienter og brukere, forhindre dobbeltarbeid og forhindre at tjenestene får dårlig kvalitet. Det er imidlertid grenser for hvor langt man kan standardisere. Ved høy grad av kompleksitet, og ved raskt skiftende omgivelser, er standardisering ikke lenger optimalt (Mintzberg, 1983).

\section{En standard er en regel}

Regler er viktige elementer i alle organisasjoner, og vi skal nå se nærmere på direktiver, normer og standarder som alle er ulike typer regler. Et direktiv er en regel som har element av å tvinge noen til visse handlinger, og som ofte har sanksjoner knyttet til seg. De kan snarere ligge i andres interesse enn i ens eget, de er eksplisitte, og vanligvis er de nedskrevet. 
Normer er internaliserte regler vi kan følge uten å behøve å reflektere over dem. Det er først når noen bryter en norm, at vi merker det. Standarder ligner på direktiver, og skiller seg fra normer på den måten at de er eksplisitte og har en tydelig opphavsperson. De skiller seg fra direktiver gjennom at de er laget med henvisning til at de er frivillige å følge. Om standarder følges eller ikke, beror ikke på standardiseringens makt eller autoritet, men heller på at mottakeren skal ha interesse av å følge dem (Brunsson \& Jacobsson, 200o).

Standardisering av arbeidsprosesser gjennom prosessorienterte modeller er tuftet på en rekke prosedyrestandarder. Dette er eksempelvis retningslinjer, manualer og veiledere for hvordan helsepersonellet skal forholde seg til sårbehandling, eller hvordan en barnevernsansatt skal behandle en bekymringsmelding ved mistanke om omsorgssvikt. Prosedyrestandarder kan ha ulik grad av detaljnivå, de kan være utledet fra ulike kilder, og mottakergruppene kan variere. Denne typen standard forsøker altså å standardisere selve innholdet av arbeidet, noe som tidligere ene og alene var overlatt til den enkelte profesjonsutøver (Timmermans \& Berg, 2003).

\section{Fra idé til praksis}

Standardisering som begrep kan defineres som «prosessen fra behov/ idé til ferdig utviklet standard» (Standard Norge, 2019). Det er mange aktører som lager regler i ulike settinger uten at vi er oppmerksomme på deres eksistens; reglene bare er der. Og verden er full av standarder og «standardiserere» (Brunsson \& Jacobsson, 2000). Standardiseringsarbeid foregår i alle organisasjoner og berører ulike nivåer samt forholdet mellom ulike aktører i organisasjoner. Internt i organisasjonen kan det være en leder, rådgivere i støttefunksjoner, en profesjonsgruppe eller flere profesjoner som samarbeider om å utarbeide nye standarder. Standardiseringsarbeid foregår også utenfor organisasjoner - i den hensikt å regulere andre organisasjoner. I organisasjonsforskningen har det vært lite oppmerksomhet rundt nettopp dette, som ofte omtales som reguleringer (Ahrne, Brunsson \& Tamm Hallström, 2007). For helse- og velferdsfeltet kan det eksempelvis være Helsedirektoratet, Kunnskapssenteret eller en 
internasjonal organisasjon som har laget standarden, og da gjerne i form av retningslinjer, veiledere eller prosedyrer.

Hva så, når idéer om standardisering skal implementeres i den hensikt å forbedre eksisterende praksis? Her er litteraturen entydig på at dette er svært utfordrende. Pfeffer \& Sutton (200o) så nærmere på hva som skjedde i organisasjonene når nye løsninger ble introdusert, og de fant at seksti prosent av idéene aldri ble tatt i bruk. Tretti prosent av de idéene som ble tatt inn, ble faktisk tatt i bruk, men ikke slik de var tenkt. Kun ti prosent av idéene som ble tatt inn, ble ansett som vellykkete i den forstand at idéen ble omsatt til endring av praksis (Pfeffer \& Sutton, 2000). Selv om denne studien ikke eksplisitt tok for seg idéen om prosessorienterte modeller, viser andre studier til at implementering er utfordrende (Bjurling-Sjöberg, Wadensten, Pöder, Jansson \& Nordgren, 2018; Fineide, 2012; Holroyd-Leduc, mfl., 2013; Mccrone, Jarrett, Evans-Lacko \& Thornicroft, 2010).

Det kan være mange årsaker til «gapet» mellom idé og praksis. Én årsak kan være at standardisering gjennom prosedyrer er det mest radikale og direkte forsøket på å foreskrive personellets handlinger (Timmermans \& Berg, 2003). Standardisering gir nettopp muligheter for å kontrollere og regulere hvordan den ansatte skal utføre arbeidet sitt: «Because the range of stimuli is greatly reduced by standardisation and specialising in one activity, the subordinate has fewer opportunities to make decisions that maximise personal interest rather than the organisation's interests» (Perrow, 1986, s. 129). Profesjoner har jurisdiksjon over visse arbeidsområder som de søker å kontrollere samt hindre at andre profesjonsgrupper kommer inn på (Abbott, 1998). Prosedyrene kan således legge normative føringer for arbeidsutførelsen. En annen årsak til «gapet» mellom idé og praksis kan være organisatorisk dekopling. Dette fenomenet viser til hvordan organisasjoner aktivt og med hensikt dekopler for å unngå konflikter og tap av legitimitet - både innad i organisasjonen og utad overfor omgivelsene. Dette er et vanlig organisatorisk fenomen: «...these new practices and procedures function as powerful myths» (Meyer \& Rowan, 1977, s. 340).

Det kan være flere forklaringer til at dekopling finner sted, og en standard fortolkning er at den nye idéen (her idéen om prosessorienterte 
modeller) ikke passer inn i eksisterende arbeidsmåter og praksiser. De nye idéene kan altså sees som symboler som kan bidra til å gi legitimitet snarere enn å forbedre eksisterende praksiser. Standardiseringstiltak blir ofte forklart med at det er behov for noe nytt, som en løsning på problemer eller som en del av organisasjonens strategier. Når organisasjonene viser til at de adopterer disse nye idéene, blir disse som et slags «utstillingsvindu» overfor sine omgivelser (Brunsson \& Jacobsson, 2000; DiMaggio \& Powell, 1991; Scott \& Meyer, 1994).

Det kan altså være en rekke organisatoriske utfordringer i standardiseringsarbeidet som må håndteres for at prosessorienterte modeller kan bidra til bedre samordning. På et operativt nivå er det interessant å studere de som kan omtales som «regelmakere», og som sitter i førersetet i standardiseringsarbeidet. Her vil jeg hevde at det kan være en sammenheng mellom hvordan standardiseringsarbeidet gjennomføres, og hvorvidt behandlingslinjen vil kunne anvendes og tas i bruk som et samordningsverktøy. Inspirert av Fernler \& Helgesson (2006: 36) vil sammenhengen mellom kunnskapsbase, regelproduksjon og det å følge regler illustreres slik:

Figur 1 - En enkel fremstilling av forholdet mellom kunnskap og regler.

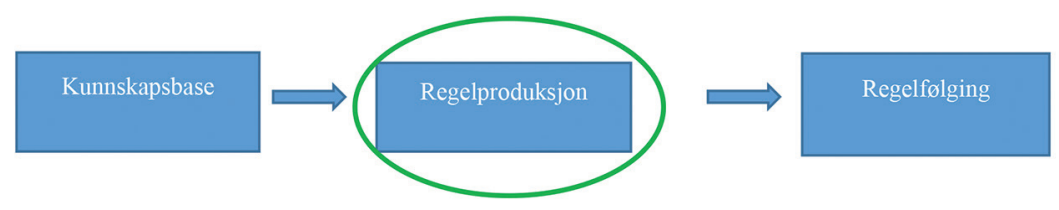

Figur 1. Rasjonell regelproduksjon (Kilde: Fernler \& Helgesson 2006, s. 36).

Denne tradisjonelle måten å forstå forholdet mellom kunnskap og regler på er tuftet på idéen om at kunnskapsbasen som anvendes under standardisering, er noe som er stabilt og entydig. Dette er jo for så vidt i tråd med standardiseringens natur, at standardisering skal bidra til å eliminere usikkerhet (Mintzberg, 1983). I praksis vil arbeidet med standardisering bestå av sosiale grupper med ulike aktører som kan ha ulikt kunnskapsgrunnlag, ulike interesser og ulike formål. Vi har sett at det kan være flere mulige årsaker til de utfordringene som kan oppstå ved implementering av nye idéer. I tråd med Evans-Lacko mfl. 
(2010), som hevder at «successful implementation of care pathways is dependent on the development process» (Evans-Lacko mfl., 2010, s. 4), vil jeg belyse hvordan samordningsaspektet ble håndtert under selve standardiseringsarbeidet.

\section{Metode}

Analysen bygger på data som ble innhentet i forbindelse med et doktorgradsstudium i arbeidsvitenskap, der jeg så nærmere på hva som skjedde med profesjonsutøvelsen når idéer om standardisering møtte lokal arbeidspraksis (Fineide, 2012). Denne studien hadde særlig oppmerksomhet på hvilke typer behandlingsfaglig kunnskap som fikk innpass i de to ulike behandlingslinjene for ADHD.

Metodene som ble benyttet i studien, var semistrukturerte intervjuer av de som hadde deltatt i standardiseringsarbeidet, og deltakende observasjon med videopptak av møter. Totalt 27 profesjonsutøvere fra ulike kommunale virksomheter og spesialisthelsetjenesten ble intervjuet og/ eller observert. Dette var rådgivere ved PPT (Pedagogisk psykologisk tjeneste), kliniske psykologer, overleger i psykiatri, barnepsykiater, helsesøstre, fysioterapeut, vernepleier, sosiallærer/rådgiver ved skole og rådgivere i spesialisthelsetjenesten som fungerte som såkalte fasilitatorer under standardiseringsarbeidet (Fineide, 2012, s. 45). I tillegg ble det gjennomført en dokumentanalyse av prosjektplaner, møtereferater og annet.

Som empirisk grunnlag for dette kapitlet har jeg anvendt de transkriberte intervjuene, observasjonene og dokumentene med det formål å belyse hvordan samordningsaspektet ble håndtert da de to behandlingslinjene for ADHD ble laget. Jeg har sett på hvem som tok initiativet til å lage behandlingslinjene, hvem som deltok i standardiseringsarbeidet, og hvilke arbeidsformer som ble benyttet. Videre har jeg sett på hvilke verktøy som ble anvendt, og hvordan problemene som dukket opp under standardiseringsarbeidet underveis, ble løst. Dette blir presentert i de to neste avsnittene. Ut av denne beskrivende analysen tegnet det seg - tematisk sett - tre organisatoriske utfordringer som jeg diskuterer. Oppsummert går denne studien i dybden, med en kombinasjon av deskriptivt og eksplorerende design, og analysene er karakterisert av en 
kombinasjon av induktive og deduktive tilnærminger (Andersen, 1997; Jacobsen, 2005; Yin, 2003).

Innledningsvis redegjorde jeg for problemstillingen som handler om hvilke organisatoriske utfordringer som bør håndteres for at prosessorienterte modeller kan bidra til bedre samordning. Jeg har nå reanalysert tidligere innhentete data om hvordan to ulike behandlingslinjer for ADHD ble laget, fordi tematikken fortsatt er svært tidsaktuell. Det styrende rammeverket - med de politiske føringene om standardisering i form av prosessorienterte modeller - er blitt enda tydeligere de senere årene, og det er svært mange aktører som arbeider med ulike former for standardisering i form av pakkeforløp, pasientforløp og lignende. Behandlingslinjen for voksne med ADHD er et eksempel på en prosessorientert tilnærming som er avgrenset til noen få avdelinger innenfor ett sykehus, og dette er et illustrerende eksempel på det standardiseringsarbeidet som i dag foregår innenfor spesialisthelsetjenesten. Men det kan også illustrere standardiseringsarbeid som foregår i andre deler av helse- og velferdstjenestene. Behandlingslinjen for barn og unge med ADHD var basert på behovet for samordning mellom spesialisthelsetjenesten, kommuner og fastleger, og dette er en aktuell illustrasjon på de nyere politiske føringene med en forventning om at spesialisthelsetjenesten bør bevege seg utenfor egne enheter i arbeidet med standardiserte pasientforløp.

\section{Standardisering i psykisk helsearbeid}

Flere norske sykehus har utviklet behandlingslinjer for ADHD, og noen er tilgjengelige på nettsiden til Helsebiblioteket, som beskriver følgende om behandlingslinjer:

En behandlingslinje er en oversikt over anbefalt håndtering av en sykdom gjennom et tidsforløp. Verktøyet kan også kalles et standardisert pasientforløp. Poenget er å skape forutsigbarhet og god samhandling. (Folkehelseinstituttet, 2014)

Helsebiblioteket skriver videre at både retningslinjer og behandlingslinjer er verktøy som brukes for å styre kvaliteten i helsevesenet, og at behandlingslinjer beskriver hvilke tiltak som skal gjennomføres, 
hvem som skal gjennomføre dem, når de skal gjennomføres, og hvilket resultat man kan forvente: «Én behandlingslinje kan inkludere mange kunnskapsbaserte fagprosedyrer. Den inneholder også standardisert informasjon til pasienter» (Folkehelseinstituttet, 2014).

Jeg skal nå presentere hvordan de to ulike behandlingslinjene for ADHD ble laget. Standardiseringsarbeidet foregikk til ulik tid, og ulike aktører var involvert, men de ble utarbeidet innenfor det samme helseforetaket, heretter omtalt som Sykehuset. På det tidspunktet arbeidet med behandlingslinjen for barn og unge startet opp, ble behandlingslinjer definert som «en dokumentert beskrivelse av et forventet pasientforløp for en definert diagnosegruppe, forankret i faglig evidens og koplet til effektiv ressursutnyttelse og målbare resultater» (Sykehusets definisjon av behandlingslinjer). Arbeidet med å lage de to behandlingslinjene presenteres kronologisk i hvert sitt avsnitt. Den første delen belyser den organisatoriske konteksten gjennom en nærmere tre år lang standardiseringsprosess for å utvikle en behandlingslinje for barn og unge med ADHD.

\section{Behandlingslinje for barn og unge med ADHD}

Idéen om å utvikle behandlingslinjen kom fra profesjoner som arbeidet ved BUP (Avdeling for barne- og ungdomspsykiatri) og BUPP (barne- og ungdomspsykiatrisk poliklinikk) på Sykehuset. Dedikerte profesjonsutøvere, spesielt en nevropsykolog og en barnepsykiater, hadde deltatt i Gjennombruddsprosjektet, som ble finansiert av Den Norske Lægeforenings fond for standardisering og kvalitetsforbedring i spesialisthelsetjenesten (Hammer \& Torp, 2006, s. 8). At ADHD ble gjenstand for et slikt prosjekt, hadde sin årsak i at det var publisert en rapport fra SINTEF (Andersson mfl., 2004), som tilsa at det var et presserende behov for å finne et verktøy som kunne bøte på de store koordineringsproblemene i oppfølgingen av barn og unge med ADHD. Her ble det - gjennom å bruke statistisk prosesskontroll (SPC) - etablert lokale forbedringsteam som veiledes av prosessendringsrådgivere gjennom en endringsperiode på rundt et halvt år. I løpet av denne tiden ble det gjennomført tre forbedringsseminarer, hvor ekspertgruppen, veiledere og forbedringsteamene kom sammen og utvekslet erfaringer og idéer. SPC gjør det mulig å gjennomføre 
kontinuerlige forbedringer og målinger av for eksempel ventetider, varighet av de ulike prosedyrene, liggetid og ressursbruk (Nyen, 2009). SPC kan sees som en teknisk innretning som brukes i Lean-konseptet, der den «magre og slanke» produksjonen - med fravær av sløsende faktorer - blir sett på som den mest effektive (Stewart mfl., 2009). Metoden er hyppig brukt på norske sykehus for å optimalisere arbeidsprosessene. Et poeng med den er å få et sikrest mulig kunnskapsgrunnlag om hvilke samordningsutfordringer som eksisterer, slik at de nye arbeidsprosessene bidrar til mer helhetlige tjenester for pasienten.

De organisatoriske rammene rundt behandlingslinjen for barn og unge med ADHD var et prosjekt som ble ledet av Barne- og ungdomspsykiatrien (BUP) i et norsk helseforetak. De som ledet prosjektet, hadde selv vært deltakere i Gjennombruddsprosjektet. Det ble etablert fem team med utgangspunkt i hver av de fem regionale barne- og ungdomspsykiatriske poliklinikkene (BUPP). Teamene besto først og fremst av profesjonsutøvere som arbeidet i BUPP og i kommunene, og de ble ledet av en representant for BUP eller BUPP. Rundt femti profesjonsutøvere var involvert i standardiseringsarbeidet. Det ble etablert en referansegruppe for prosjektet som blant andre besto av ADHD-foreningen, Nasjonalt kompetansesenter for AD/HD samt Fylkesmannen.

Arbeidsformen i prosjektet var at de fem teamene drøftet forslag til «hvem som skulle gjøre hva», de foreslo lokale tilpasninger og kom med kommentarer og forslag til manualer som ble lagt fram av prosjektledelsen. I tillegg ble det utarbeidet flytskjemaer som beskrev et typisk eksempel på dagens situasjon rundt oppfanging, vurdering og henvisning. Her ble det brukt symboler som viste start og slutt på arbeidsprosessen: fra mistanke om ADHD til henvisning og utredning med påfølgende aktivitetsbeskrivelser for de ulike aktørene og enhetene som var involvert. Det synes ikke som om det ble foretatt analyse av de reelle samordningsutfordringene mellom de berørte enhetene.

De fem teamene hadde egne møter, og det var felles samlinger for alle deltakerne. De berørte enheter for denne behandlingslinjen var fastlegene, Pedagogisk-psykologisk tjeneste (PPT), helsestasjonene, barneverntjenesten, skolene/barnehagene og de fem regionale BUPP-kontorene. I praksis vil det si at dette prosjektet handlet om å lage en behandlingslinje som skulle gjelde for hele fylket. 
Det ble tidlig etablert noen hovedprinsipper for barn og unge med ADHD (og deres familier) om at dette var et felles ansvar for kommunen og BUPP. Det som kunne gjøres av arbeidsoppgaver i kommunene, skulle gjøres der. Som hovedregel skulle diagnostiske konklusjoner og (hvis aktuelt) medikamentell behandling forankres i spesialisthelsetjenesten (BUPP). Et viktig prinsipp var at fastlege og PPT skulle gjøre sine utredninger før henvisning til BUPP. PPT skulle da innhente nødvendige supplerende opplysninger fra skole og helsestasjon.

Arbeidet med å utvikle denne behandlingslinjen ble drevet av dedikerte profesjonsutøvere. Således var det profesjonene selv som i praksis besluttet hva behandlingslinjen skulle inneholde, siden de berørte lederne var fraværende i standardiseringsarbeidet. Det var også fravær av diskusjoner og analyser av potensielle utfordringer rundt særlig to sentrale forhold, nemlig usikkerheten i kunnskapsgrunnlaget som eksisterer rundt denne diagnosen, og usikkerheten rundt prinsipper for arbeidsdeling - og da særlig mellom barne- og ungdomspsykiatrien, fastlegene og de øvrige kommunale tjenestene, som for eksempel PPT. Vi skal nå se mer konkret hva sistnevnte handlet om.

Flere av deltakerne som ble intervjuet, var opptatt av at fastlegene ikke var representert i standardiseringsarbeidet. Arbeidsgruppene skulle altså lage en ny prosedyre (her omtalt som manual) for fastlegene - basert på de etablerte prinsippene om ny arbeidsdeling - uten at «stemmen» som kunne representere fastlegene, var til stede. Prosjektledelsen diskutert hva de kunne gjøre med dette, om de eksempelvis skulle ha informasjonsmøter med alle legene. Med utgangspunkt $i$ at det er flere hundre fastleger i denne regionen, var det vanskelig å nå alle, og det «bare rant ut» (i sanden), som en av informantene uttrykte det.

Ingen i arbeidsgruppene hadde lederposisjoner. Dette var flere av informantene opptatt av. En psykolog i BUP som ledet en av de fem arbeidsgruppene, forteller at ingen hadde lederrolle i sine respektive virksomheter:

Ikke noen av oss hadde den type innvirkning på våre arbeidsplasser, direkte ... og alle måtte gå linjen opp i forhold til sine ledere når vi skulle informere om prosessene. 
Det kan synes som dette var mindre problematisk i BUP og BUPP, siden dette er innenfor spesialisthelsetjenesten, og siden det nettopp var her prosjektet hadde sin ledelse og forankring. Men det handlet ikke bare om å informere om standardiseringsarbeidet. Dette skulle (for mange aktører) munne ut i en ny arbeidsdeling mellom kommunale virksomheter, fastleger og barne- og ungdomspsykiatrien. Spesielt handlet det om etablering av nye arbeidsprosesser for henvisning, der PPT og fastlegene skulle utføre utredninger av barnet før henvisning til BUPP, slik det ble beskrevet i manualene.

Det ble utarbeidet brosjyrer med manualer for hver enkelt virksomhet, og disse ble sendt til alle kommuner, fastleger og avdelinger i spesialisthelsetjenesten. De var også tilgjengelige i elektronisk format på internett og som CD.

Som nevnt ble behandlingslinjen for voksne laget etter at behandlingslinjen for barn og unge var ferdigstilt, og det skjedde innenfor det samme helseforetaket. Vi skal nå se nærmere på hvordan denne ble laget.

\section{Behandlingslinje for voksne med ADHD}

Dette standardiseringsarbeidet hadde en varighet på nærmere to år, og det ble gjennomført i linjen på Sykehuset, det vil si ikke som et eget prosjekt. Initiativet sprang ut fra et fagmiljø som var opptatt av at voksne ADHD-pasienter ikke ble fanget opp og at de var «kasteballer» mellom de ulike enhetene på Sykehuset. Oppstarten av arbeidet ble godkjent av divisjonsdirektøren, som oppnevnte en overlege i psykiatri som leder av arbeidet, her omtalt som BAL (behandlingslinjeansvarlig lege). Vedkommende rekrutterte en arbeidsgruppe med psykologer og psykiatere som representerte både sengeposter og poliklinikker. En brukerrepresentant var også til stede på de fleste møtene. Det var to rådgivere fra HR-enheten som støttet opp under arbeidet med praktiske oppgaver som møteinnkallinger og referater, og den ene av disse var fasilitator. Dette er en rolle som sørger for å stille arbeidsgruppen spørsmål samt anvende «gule lapper», flytskjemaer og digitale verktøy under standardiseringsarbeidet.

Da arbeidsgruppen skulle starte opp, var meningen at den skulle ta utgangspunkt i behandlingslinjen for barn med ADHD, og at den skulle 
omfatter både Sykehuset, kommunene og fastlegene. Men for å gjøre standardiseringsarbeidet overkommelig, ble det i dialog med divisjonsdirektøren besluttet at behandlingslinjen kun skulle gjelde for spesialisthelsetjenesten. De ulike enhetene som behandlingslinjen for voksne med ADHD skulle omfatte, var Seksjon for langtidsbehandling av rus og psykisk helse, Seksjon for avgiftning og kartlegging, og Seksjon for utredning og behandling. Den skulle videre gjelde for Sosialmedisinsk poliklinikk (SMP), som har fem regionkontorer, og Distriktspsykiatrisk senter (DPS), som har fire regionkontorer og tilbyr både dag- og døgnbehandling. Alle enheter er ved Sykehuset.

Arbeidsformen var ofte slik at arbeidsgruppen diskuterte og kom med forslag i møtene, og at den gjerne sendte forslagene med dokumentasjon på e-post til fasilitatoren og BAL. Deretter la fasilitatoren dette inn i verktøyet, og viste det fram på neste møte. Var det større temaer som skulle utredes, ble det satt ned arbeidsgrupper som kom med forslag som ble diskutert i møtene. Av referatene fremkommer det at teamet ut fra egne erfaringer simulerte de ulike problemstillingene som kan være aktuelle i to valgte caser: «En voksen gjennomsnittsperson, simplex med ADHD som ikke er fanget opp», og caset «kompleks - ADHD som er mennesker med flere og sammensatte psykiske lidelser».

Her brukte arbeidsgruppen flippover-ark utover møtebordet og utarbeidet flytskjemaer med "gule lapper» som visualiserte hvilke oppgaver som ble utført, og hvilke aktører som var involvert i arbeidsprosessene rundt fire «hovedstasjoner» i forløpet. Dette var «oppfanging», «henvisning», «utredning og diagnostisering» samt «behandling, tiltak og oppfølging».

De forholdt seg til slik de opplevde dagens situasjon, og det var vanskelig å avholde seg fra beskrivelse av tiltak for å gjøre forbedringer (noe som ble lagt inn senere). Det kom fram at det var en mulig gevinst i å standardisere utrednings- og diagnostiseringsverktøyene, men at det var behov for opplæring, og at det var viktig at ekspertisen i utredning og diagnostisering av ADHD skulle være kvalitetsmessig god nok.

Det viste seg at det var få pasienter som var registrert med en ADHD-diagnose i det kodesystemet som Sykehuset bruker (ICD 10). Dette ble sett i sammenheng med at det var manglende kompetanse på 
ADHD i fagmiljøene. For å sjekke ut nettopp dette kartla arbeidsgruppen de ansattes kompetanse på utredning og diagnostisering av ADHD ut fra de gjeldende kriteriene i den nasjonale veilederen IS-1244. Resultatet var nedslående:

Det fantes så å si ikke noe kompetanse på ADHD i forhold til utredning. Og diagnostisering ... Det var noe på DPS, ingenting på SMP ... og lite innenfor sengepostene eller på poliklinikkene ...

Intervju med fasilitator

Problemene med at pasienter ikke fanges opp, og at de ikke blir diagnostisert, kan illustreres med hjertesukket som en psykiater kom med på et arbeidsgruppemøte i forbindelse med at enkelte pasienter som har ADHD, blir feildiagnostisert:

De har gått gjennom hele systemet, og folk oppe i 30-40-årene som har helt klassiske symptomer på det (ADHD), og ikke blitt tatt på alvor noe sted ... fått ødelagt mesteparten av sitt voksne liv ... fordi at ingen har sett det ...

Observasjon under et arbeidsmøte

Feildiagnostisering eller underdiagnostisering kan resultere $i$ at pasienter blir «kasteballer» mellom de ulike enhetene og virksomhetene i helse- og velferdssektoren. Med utgangspunkt i egen divisjon i spesialisthelsetjenesten ble det fastslått at det var samordningsproblemer internt, og at ventetiden for pasientene var for lang.

På spørsmål om hvem som skulle utrede og diagnostisere, tok arbeidsgruppen utgangspunkt i de ulike enhetene innenfor divisjonen. I et referat fra et arbeidsgruppemøte sakses følgende:

Vi vet at det er betydelig ventetid på utredning og diagnostisering og det er et faglig ønske om at de som gjør dette skal voere godt kvalifisert og de skal arbeide så mye med det at det blir effektivt og godt nok. I utgangspunktet er det DPS som har denne oppgaven. Det det må avklares hvem og hvor dette skal gjøres ut i fra dette perspektivet.

BAL fikk avklart spørsmålet med ledelsen for divisjonen. Her ble det besluttet at utredning og diagnostisering skulle utføres der pasienten først tas inn i divisjonen, enten det er DPS, SMP eller en sengepost. Dette 
betyr i praksis at utrednings- og diagnostiseringsoppgaver som tidligere var forbeholdt få enheter, nå skulle utføres av alle de berørte enheter i divisjon for psykisk helsevern. DPS spiller jo en hovedrolle, men her så arbeidsgruppen raskt at det var behov for internopplæring, spesielt av de ansatte på SMP.

I praksis har et par enheter tradisjonelt hatt utredning og diagnostisering av denne pasientgruppen som sitt «domene», og gjennom denne prosedyren ble således dette rokket ved. Av møtereferater og observasjoner ser det ikke ut som om dette var et tema som ble problematisert.

Det neste problemet som måtte løses, var å finne frem til et standardisert verktøy for utredning og diagnostisering. Dette var et stadig tilbakevendende tema på møtene. Her vil jeg vise til en sekvens fra et møte i arbeidsgruppen, der den går gjennom forslaget til prosedyren rundt dette.

Arbeidsgruppen var blitt utfordret på å finne fram til standardiserte utrednings- og diagnostiseringsverktøy som kunne brukes på alle enheter, uavhengig av profesjonstilknytning. Fasilitatoren forklarte at det var vanskelig for gruppen å komme fram til et standardisert verktøy:

Vi har hatt mange diskusjoner ... på verktøyene, valg av verktøy ... Og det er fordi at alle de som sitter i den gruppa har ulike erfaringer og ulike ... noen er mer glad i dem verktøyene enn i dem verktøyene ... Og noen jobber mer med rusrelaterte problemstillinger og andre mer med psykiatriske problemstillinger. Og da vil ulike verktøy være naturlig å bruke.

Intervju med fasilitator

Fasilitatoren fortsetter med å fortelle at de fortsatt har en vei å gå, men slik hun tolker det, har de i hovedsak blitt enige om hvilke utrednings- og kartleggingsverktøy som skal brukes. Dette har de fått til gjennom at de som er med på standardiseringsarbeidet, har en felles interesse for denne pasientgruppen. De er glødende opptatt av pasientene, og de kjenner pasientenes problemer på ulike nivåer, formidler hun. Selv om arbeidsgruppen har forholdt seg til den nasjonale veilederen i diagnostikk og behandling av ADHD, har det vært mange diskusjoner for å komme fram til et felles sett av standardiserte verktøy. Og ikke alltid løses uenighet ved konsensus. Jeg observerte arbeidsgruppen i en avsluttende diskusjonen om hvilke verktøy som skulle legges inn under hovedstasjonen. Temaet 
var engasjerende, og noen snakket innimellom i munnen på hverandre om tester, pasientintervjuer og anamneser ut fra ulike faglige perspektiver. Her kommer uenigheten som tydeligvis har vært rundt disse testene, opp igjen. Deltakerne er engasjerte, og en psykologspesialist fra DPS som er ny i arbeidsgruppen, uttrykker spørsmål rundt en av testene, men blir stoppet av en psykologspesialist fra et annet DPS. Denne sekvensen fra møtet illustrerer at den nye psykologspesialisten som ikke hadde vært med på å utarbeide behandlingslinjen over tid, hadde spørsmål som «forstyrret» det som allerede var lagt inn, og som nå var besluttet av BAL. Spørsmålet ble ignorert, og teamet gikk videre til neste prosedyre.

Da arbeidet med behandlingslinjen nærmet seg sluttøring, fikk arbeidsgruppen midler internt og eksternt for å finansiere et samkjørt og godt «diagnostisk team», som den kalte det. Dette besto av et opplæringsprogram i utredning og diagnostisering for førti psykiatere og psykologspesialister fra de ulike enhetene. De fikk her et kompetansehevende kurs som gikk ut på at de skulle bruke den samme metodikken på utredning og diagnostisering. Kursdeltakerne skulle i etterkant lære opp sine kollegaer. Dette opplæringsprogrammet kom i gang omtrent på det tidspunktet behandlingslinjen skulle implementeres i divisjonen.

De organisatoriske rammene handlet om tydelig ledelse, klargjøring av deltakernes oppgaver og roller, fast møtestruktur, skriftlig møteinnkalling og referater, opprettelse av ad hoc-grupper, gjennomføring av simuleringsaktiviteter og bruk av prosessmodelleringsteknikk. Problemer underveis ble enten løftet opp til ledelsen for avgjørelse, eller så fant arbeidsgruppen løsningen selv.

\section{Organisatoriske utfordringer}

De to foregående avsnittene ga et innblikk i hvordan de to behandlingslinjene ble produsert, og utgjør dermed empiriske illustrasjoner i diskusjon av hvilke organisatoriske utfordringer som må håndteres for at prosessorienterte modeller kan gi bedre samordning. Selv om de to behandlingslinjene dekker samme diagnose, er standardiseringsprosessene ulike. De to casene utfyller hverandre, men de kontrasterer også hverandre på en slik måte at det er mulig å se et empirisk mønster. 
Idéen om å produsere de to behandlingslinjene var tuftet på det faktum at pasienter med ADHD ikke blir fanget opp. Det var lange ventetider på utredning og behandling, og det var uklart hvem som skulle gjøre hva. En prosessorientert tilnærming handlet her om å identifisere kritiske områder som dobbeltarbeid, ventetider og annet som kunne utgjøre samordningsutfordringer. Deretter handler denne tilnærmingen om å beskrive arbeidsprosessen gjennom definerte deler av helse- og velferdssystemet. I prinsippet innebærer prosessmodeller at man fremhever sekvensiell behandling i beskrivelser av arbeidsflyten i - og mellom (horisontal) - de ulike virksomhetene. Samtidig krysses de (vertikale) etablerte strukturene innenfor de berørte virksomhetene (Fineide \& Ramsdal, 2014). De tre organisatoriske utfordringene jeg vil diskutere her, er anvendelsesområdet for behandlingslinjen, hensiktsmessige verktøy og teknikker samt implementering, herunder kompetansehevende tiltak.

\section{Anvendelsesområdet for behandlingslinjen}

Den første organisatoriske utfordringen som må håndteres, er anvendelsesområdet for behandlingslinjen. Behandlingslinjen for barn og unge med ADHD er meget oppfattende - i den forstand at den inneholder fire «hovedstasjoner» (oppfanging, henvisning, utredning og diagnostisering samt oppfølging og tiltak) med tilhørende syv manualer, hver for de ulike gruppene av aktører disse gjelder for. Med unntak av manualen for foreldre handler da denne behandlingslinjen om å regulere hva seks ulike profesjonsgrupper skal utføre innenfor disse fire hovedstasjonene. En rekke kommuner i dette fylket blir berørt, og således også en rekke kommunale virksomheter. Det var også flere hundre fastleger i denne regionen. Med et slikt anvendelsesområde er denne behandlingslinjen svært ambisiøs, nærmest et verktøy som «i teorien» er basert på gode intensjoner, men som blir vanskelig å omsette i praksis.

Når det gjelder behandlingslinjen for voksne med ADHD, ble anvendelsesområdet avgrenset til å gjelde kun én divisjon i spesialisthelsetjenesten. Hensikten var å gjøre standardiseringsarbeidet overkommelig. De ulike enhetene som behandlingslinjen skulle gjelde for, var tre seksjoner, fem sosialmedisinske poliklinikker (SMP) og fire distriktspsykiatriske 
sentre (DPS). De profesjonene som hadde en hovedrolle i denne behandlingslinjen, var psykiatere og psykologer.

Avgrensing av anvendelsesområde kan bidra til å sikre et felles kunnskapsgrunnlag for hvilke samordningsproblemer som skal løses, og det kan bidra til involvering av de aktørene og enhetene som behandlingslinjen skal gjelde for (Fineide \& Ramsdal, 2014). En avgrensning synes å gjøre standardiseringsarbeidet overkommelig, men kan også øke muligheten for en vellykket implementering.

De to behandlingslinjene ble laget ut fra et stort behov for å bedre samordningen overfor pasienter med ADHD, og dedikerte profesjonsutøvere var sterke drivkrefter for å utvikle et redskap som kunne bøte på problemene. Når det gjelder behandlingslinjen for barn med ADHD, var det også de profesjonelle som i praksis besluttet hva den skulle inneholde, siden de berørte lederne var fraværende i produksjonsprosessen.

Lederinvolvering i alle de berørte virksomhetene ville her være viktig for å tildele ressurser, organisere opplæring i de nye manualene samt sikre legitimitet for behandlingslinjeidéen (Brunsson \& Jacobsson, 2000). Men deltakelse av ledere i standardiseringsarbeidet ville også kunne utgjøre hindre ved at det ville bli stilt spørsmål om både idéen og manualene. I likhet med manglende involvering fra fastlegene i regionen, vil også manglende lederinvolvering være en viktig mekanisme for å få tempo og fremdrift i standardiseringsarbeidet - samt sikre at det blir utarbeidet konkrete resultater i form av manualer (Brunsson \& Jacobsson, 2000; DiMaggio \& Powell, 1991; Scott \& Meyer, 1994). Fravær av diskusjoner og analyse av potensielle utfordringer rundt prinsipper for arbeidsdeling, og da særlig mellom barne- og ungdomspsykiatrien og kommunenes tjenester for barn og unge med ADHD, kan også sies å ha vært viktig for å få tempo og fremdrift i standardiseringsarbeidet. Behandlingslinjen rokket nettopp ved den etablerte arbeidsdelingen mellom flere aktører, og potensielle domenekonflikter (Abbott, 1998) kunne kommet til syne. En tett kopling mellom berørte ledere og de som satt i førersetet i standardiseringsarbeidet, kunne således virke truende på fremdriften i standardiseringsarbeidet, og muligens ført til at arbeidet med behandlingslinjen ville ha stoppet opp. Allikevel kunne en tett kopling bidratt til en felles erkjennelse av utfordringer som må løses for at behandlingslinjen skal virke etter sin hensikt. 
Når det gjelder behandlingslinjen for voksne med ADHD, var en klar kopling mellom divisjonslederen og den som ledet standardiseringsarbeidet. Imidlertid vil denne behandlingslinjen kunne omfavne en rekke enheter i spesialisthelsetjenesten, og det var her en viss begrensning på involvering fra de nærmeste linjelederne. To forhold er viktige her: Alle linjelederne hadde samme divisjonsleder, og det skulle gjennomføres opplæring i nye oppgaver.

Den første organisatoriske utfordringen er anvendelsesområdet for behandlingslinjen. Avgrensing av dette anvendelsesområdet kan bidra til at standardiseringsarbeidet blir utført tett på de som har informasjon om hvilke samordningsutfordringer som skal løses. En avgrensning kan også gi muligheter for kopling mellom de som sitter i førersetet i standardiseringsarbeidet, og de ansatte og ledelsen som behandlingslinjen skal gjelde for.

\section{Hensiktsmessige verktøy og teknikker}

En svært viktig aktivitet i standardiseringsarbeidet ser ut til å være simuleringsaktiviteter, slik de ble anvendt da behandlingslinjen for voksne med ADHD ble produsert. Simuleringsaktiviteter kan bidra til å avdekke samordningsproblemer i og mellom de ulike berørte enhetene. Å utarbeide visualiserte fremstillinger av de ulike aktivitetene gjennom hele arbeidsprosessen kan gjøre enhetene bedre i stand til å beslutte hvordan forslaget til behandlingslinje skal se ut. Den støtten som en fasilitator kan utgjøre under standardiseringsarbeidet, er viktig for at arbeidsgruppen kan få et «utenfrablikk» på de eksisterende arbeidsprosessene. Å anvende verktøy til dette formålet synes hensiktsmessig for standardiseringsarbeidet.

Statistisk prosesskontroll ble anvendt i Gjennombruddsprosjektet, i forkant av at behandlingslinjen for barn og unge ble produsert. Denne metoden er en anerkjent statistisk metode som brukes på Sykehuset i forbindelse med produksjon av behandlingslinjer (Nyen, 2009), men ble ikke benyttet da de to behandlingslinjene for ADHD skulle utarbeides. Nå tilsier jo også de fortolkningene som ble gjort ut fra Sykehusets definisjoner på behandlingslinje, at effektivitetsmålinger ble tonet ned. Men det er mulig at denne metoden (i det minste) kunne ha bidratt til 
statistiske analyser av flaskehalser, ventetider og lignende - i tillegg til annen relevant ikke-statistisk informasjon. Dette for å sikre en tettere kopling mellom behandlingslinjene og de reelle samordningsproblemene på dette arbeidsfeltet.

Den andre organisatoriske utfordringen er således å anvende hensiktsmessig verktøy og teknikker i standardiseringsarbeidet, slik at det kan gjennomføres reelle analyser av hvilke samordningsproblemer som skal løses, og av hvilke tiltak som er nødvendige for å bedre samordningen.

\section{Implementering, herunder kompetansehevende tiltak}

Begge behandlingslinjene involverte planlagte endringer i ansvars- og oppgavefordeling. Vi har sett at standardiseringsarbeidet av behandlingslinjen for voksne med ADHD avdekket at psykologene og psykiaterne på flere av enhetene hadde kompetansehull på utredning og diagnostisering. Det ble da satt i gang et eget opplæringsprosjekt, og det ble avsatt ressurser til dette.

Implementering av nye idéer er utfordrende i alle organisasjoner (Pfeffer \& Sutton, 200o; Røvik, 2016). Hvordan og med hvilke tiltak det skal jobbes, vil være avhengig av hva som skal implementeres. En plan for implementering kan sikre at det gis systematisk opplæring i de nye arbeidsoppgavene, og at det avsettes tilstrekkelige ressurser.

Vi har sett at det var ulike måter for å forstå hvilke verktøy som skulle anvendes i forbindelse med utredning og diagnostisering av voksne med ADHD, selv der kun to profesjoner (psykiatere og psykologer) deltok i standardiseringsarbeidet. Profesjoner har ulike, men noen ganger også motsetningsfylte faglige tilnærminger rundt diagnostisering og behandling (Hansen, 2007). Her blir de profesjonelles eget kunnskapsfelt utfordret. Diagnostisering i seg selv kan sies å være et felt som er preget av stor grad av usikkerhet. Selv om dette er basert på et eget klassifikasjonssystem, brukes forskjellige utrednings- og kartleggingsverktøy. Vi har også sett at oppgaver som tidligere ble utført av noen spesielle enheter, nå skulle utføres av samtlige. Dette for å redusere pasientenes ventetid på utredning og diagnostisering. Dette medførte at noen enheter og profesjoner 
som hadde denne arbeidsoppgaven som sitt «domene» (Abbott, 1998), nå skulle dele den med flere profesjonsgrupper og enheter. Prosedyrene, som i dette tilfellet handlet om å beskrive nye arbeidsprosesser for å få bedre samordning, kan således legge normative føringer for arbeidsutførelsen.

Som vi har sett av de to casene, har standardiseringsarbeidet tatt henholdsvis to år og tre år fra idé til ferdig utviklede behandlingslinjer. Det er blitt anvendt mye ressurser til dette arbeidet, først og fremst i form av tidsressurser for profesjonsutøvere.

Oppsummert er den tredje organisatoriske utfordringen at det forberedes for god implementering, og at det iverksettes kompetansehevende tiltak i samarbeid med de som skal anvende det nye verktøyet.

\section{Oppsummering}

Det er klare politiske føringer, med ambisjoner om at prosessorienterte modeller skal bidra til å løse kvalitets- og koordineringsproblemer i helse- og velfredssektoren, men det er et gap mellom idé og praksis. Gjennom å belyse hvordan selve standardiseringsarbeidet ble gjennomført da to ulike behandlingslinjer for ADHD ble laget, har jeg trukket fram tre organisatoriske utfordringer. Den første er å avklare tidlig i prosessen hvilket anvendelsesområde som behandlingslinjen skal gjelde for, og at det er en tett kopling mellom de som standardiserer, og de lederne og ansatte som skal anvende behandlingslinjen i sitt daglige arbeid. Den andre utfordringen er å bruke hensiktsmessige verktøy og teknikker i standardiseringsarbeidet, som kan bidra til reelle analyser av de samordningsutfordringene som behandlingslinjen er tenkt å bøte på. Den tredje utfordringen jeg har trukket frem, er at det planlegges for god implementering, og at det iverksettes kompetansehevende tiltak. Disse tre utfordringene er alle sentrale i standardiseringsarbeidet, og de må håndteres for at prosessorienterte modeller kan bidra til bedre samordning.

\section{Referanser}

Abbott, A. (1988). The system of professions: An essay on the division of expert labor. Chicago: University of Chicago Press. 
Ahrne, G., Brunsson, N. \& Tamm Hallström, K. (2007). Organizing organizations. Organization, 14(5), 619-624. https://doi.org/10.1177/1350508407080303

Andersen, S.S. (1997). Case-studier og generalisering. Forskningsstrategi og design. Bergen: Fagbokforlaget.

Andersson, H.W., Ådnanes, M. \& Hatling T. (2004). Nasjonal kartlegging av tilbud om diagnostisering og helhetlig behandling av barn og ungdom med hyperkinetiske forstyrrelser/ADHD, Trondheim: SINTEF Helse, Oppdragsgiver: Sosial- og helsedirektoratet.

Bjurling-Sjöberg, P., Wadensten, B., Pöder, U., Jansson, I., \& Nordgren, L. (2018). Struggling for a feasible tool - the process of implementing a clinical pathway in intensive care: A grounded theory study. BMC Health Services Research, 18(1), 831. https://doi.org/10.1186/s12913-018-3629-1

Brunsson, N. \& Jacobsson, B. (2000). A world of standards. Oxford: Oxford University Press.

Dent, M. (2008). Medicine, nursing and changing professional jurisdictions in the UK. I D. Muzio, S. Ackroyd \& J.F. Chanlat (Red.), Redirections in the study of expert labour: Established professions and new expert occupations (s.101-117). Basingstoke: Palgrave Macmillan.

DiMaggio, P.J. \& Powell, W.W. (1991). The new institutionalism in organizational analysis. Chicago: University of Chicago Press.

Fineide, M.J. (2012). Controlled by knowledge: A study of two clinical pathways in mental healthcare (Doktoravhandling). Karlstad Universitet, Karlstad

Fineide, M.J. \& Ramsdal, H. (2014). «Prosesstenkning» i helse- og velferdstjenestene -standardisering av pasientforløp og behandlingslinjer. I Vabo, S., \& Vabø, M. (Red.), Velferdens organisering (s.108-121). Oslo: Universitetsforlaget.

Folkehelseinstituttet (2014). Helsebiblioteket. Retningslinjer og behandlingslinjer for ADHD samlet ett sted. Publisert 25.11.2014, https://www.helsebiblioteket.no/ psykisk-helse/aktuelt/retningslinjer-og-behandlingslinjer-for-adhd-samlet-ett-sted Hammer, L. \& Torp, A.S. (2006). Rapport fra Gjennombruddsprosjekt Psykiatri 2003-2004. ADHD - Forbedre utredning, diagnostikk og behandling. Den norske lægeforening. Skriftserie for leger: Utdanning og kvalitetsutvikling 2006.

Hansen, G.V. (2007). Samarbeid uten fellesskap: Om individuelle planer i kommunalt psykisk helsearbeid. Karlstad Universitet, Karlstad.

Helgesson, C. \& Fernler, K. (2006). Initierad ignorans: om översättningen av kunskap till regler. I Fernler, K., \& Helgesson, C. (Red.), Kloka regler?: Kunskap i regelsamhället (s. 305-325). Lund: Studentlitteratur

Helse- og omsorgsdepartementet (2015). Nasjonal helse- og sykehusplan 2016-2019 (St. meld. nr. 11. (2015-2016)). Oslo: Helse- og omsorgsdepartementet.

Helse- og omsorsdepartementet (2008). Samhandlingsreformen. Rett behandling - på rett sted - til rett tid. (St.meld. nr. 47 (2008-2009)). Oslo: Helse- og omsorgsdepartementet. 
Holroyd-Leduc, J., Steinke, V., Elliott, D., Mullin, K., Elder, K., Callender, S., \& Hildebrand, K.A. (2013). Improving the quality of care for older adults using evidence-informed clinical care pathways. Canadian Geriatrics Journal: CGJ, 16(3), 111-113. https://doi.org/10.5770/cgj.16.62

Jacobsen, D.I. (2005). Hvordan gjennomføre undersøkelser? Innføring $i$ samfunnsvitenskapelig metode (2. utgave). Kristiansand: Høyskoleforlaget.

Meyer, J., \& Rowan, B. (1977). Institutionalized organizations: Formal structure as myth and ceremony. American Journal of Sociology, 83(2), 340-363.

Mintzberg, H. (1983). Structures in fives - designing effective organizations. New Jersey: Prentice-Hall International Editions.

McCrone, P., Jarrett, M., Evans-Lacko, S. \& Thornicroft, G. (2010). Facilitators and barriers to implementing clinical care pathways. BMC Health Services Research, $10(1), 182$.

Nyen B. (2009). Forbedringsarbeid og Statistisk Prosesskontroll (SPC) Versjon 2.o. Nasjonalt kunnskapssenter for helsetjenesten, Seksjon for kvalitetsutvikling GRUK. ISBN nr. 978-82-8121-248-o

Perrow, C. (1986). Complex organizations (3. utgave). New York: McGraw-Hill.

Ramsdal, H. \& Ramsdal, K. (2007). Organisatoriske innovasjoner i helsesektoren: Prosessbaserte virksomhetsmodeller, evidensbasert praksis og behandlingslinjer. Oppdragsrapport 2007:3. Høgskolen i Østfold, Halden.

Scott, W.R. \& Meyer, J.W. (1994). Institutional environments and organizations: Structural complexity and individualism. Thousand Oaks, CA: Sage.

Standard Norge http://www.standard.no/Standardisering/ Sist oppdatert: 2019-03-12

Stewart, P., Richardson, M., Danford, A. \& Murphy, K. (2009). "We sell our time no more": Workers' struggles against lean production in the British car industry. London. Pluto Press.

Timmermans, S. \& Berg, M. (2003). The gold standard: The challenge of evidencebased medicine and standardization in health care. Philadelphia, PA: Temple University Press.

Pfeffer, J. \& Sutton, R.I. (2000). The knowing-doing gap: How smart companies turn knowledge into action. Boston: Harvard Business School Press, 2000.

Røvik, K.A (2007). Trender og translasjoner. Ideer som former det 21. århundrets organisasjon. Oslo: Universitetsforlaget

Yin, R.K. (2003): Case study research. London: Sage Publications. 



\title{
KAPITTEL 7
}

\section{Digitalisering - løsninger og problemer}

\section{Catharina Bjørkquist}

Avdeling for helse og velferd, Høgskolen i Østfold

\begin{abstract}
Sammendrag: Dette kapitlet diskuterer muligheter og utfordringer for samordning når helse- og velferdstjenester digitaliseres. Spørsmålet om hvilke utfordringer digitaliseringen er tenkt å løse, analyseres gjennom en studie av nasjonale policydokumenter. Spørsmålet om hvordan digitalisering påvirker samordning av helseog velferdstjenester, besvares gjennom en litteraturstudie hvor tidligere forskning drøftes. Den offentlige politikkens begrunnelser for digitalisering legger vekt på effektivisering og frigjøring av ressurser. Digitale fagsystemer kan hindre kommunikasjon og informasjonsflyt blant annet fordi informasjonen ikke er oppdatert, eller fordi ansatte mangler tilgang. IKT-systemer bidrar til å etablere felles faglige rammer, men skaper også mindre profesjonelt handlingsrom. Tjenesteytere finner ulike måter å gjøre motstand mot de digitale systemene på. I noen sammenhenger gir de uttrykk for at de bruker for mye tid på skjerm, tid som kunne vært anvendt med bruker. Slike forhold kan skape utfordringer med å samordne tjenester. Digitale løsninger bidrar i seg selv ikke til å løse eksisterende samordningsproblemer.
\end{abstract}

Nøkkelord: samordning, digitalisering,tjenester, organisasjon, profesjon, velferdsteknologi

\section{Innledning}

Skandinaviske land har generelt kommet langt med hensyn til digital utvikling. Tilgangen til internett i befolkningen er høy, og en stor andel bruker internett daglig. På politisk hold har man et optimistisk fremtidsbilde av hva teknologi kan bidra med, og man har allerede kommet langt når det gjelder innføring av digital informasjons- og kommunikasjonsteknologi (IKT) i politikk og forvaltning. IKT påvirker forholdet mellom

Sitering av dette kapitlet: Bjørkquist, C. (2019). Digitalisering - løsninger og problemer. I C. Bjørkquist \& M. Jerndahl Fineide (Red.), Organisasjonsperspektiv på samordning av helse- og velferdstjenester (s. 169-191). Oslo: Cappelen Damm Akademisk. https://doi.org/10.23865/noasp.66.ch7.

Lisens: CC BY 4.0 
forvaltningen, tjenesteyterne og borgerne (Snellen, 2002). Det er store forventinger til at digitalisering av helse- og velferdstjenestene medfører effektivisering og økt produktivitet innen offentlige tjenester (Breunig \& Skjølsvik, 2017).

Digitale løsninger som informasjons- og kommunikasjonsteknologi inngår i forvaltningen generelt og $\mathrm{i}$ helse- og velferdstjenestene spesielt. Det kan være teknologi som endrer arbeidsorganiseringen, de ansattes arbeidsmåter og arbeidsprosesser så vel som den offentlige sektoren selv. Informasjonsflyt gjennom elektronisk samhandling som eLink og digital sykefraværsoppfølging er eksempler på slike digitale løsninger. Andre teknologiske løsninger er mer direkte rettet mot brukere av helsetjenester og velferdsytelser. Formålet kan være å øke deres opplevelse av trygghet, lette sosial kontakt med andre eller kompensere for sviktende hukommelse. Trygghetsalarmer, videokommunikasjon, kalender med påminnelsesfunksjoner og automatisk måling av blodsukker er eksempler på hjelpemidler. Ofte knyttes diskusjonen om bruk av slike teknologiske løsninger til at eldre brukere fortrinnsvis skal bo lenger hjemme eller i omsorgsbolig. Teknologi er da tenkt å enten være et supplement til nåværende tjenester eller en erstatning for andre tjenester.

Offentlig politikk generelt, og digitalisering spesielt, kan knyttes til en diskusjon om utfordringer i forbindelse med samordning på tvers av forvaltningsnivåer, politikkområder og virksomheter. Mye av oppmerksomheten fra nasjonale myndigheter når det gjelder samordning og digitalisering, er rettet mot felles løsninger, standarder og annen infrastruktur (Schartum, Jansen \& Tranvik, 2017).

Helse- og velferdstjenester som leveres av henholdsvis spesialisttjenestene og ulike kommunale tjenester, må også samordnes for å sikre et helhetlig tilbud til brukerne. Brukere med komplekse behov mottar flere kommunale tjenester samtidig - som hjemmesykepleie, rustjeneste, dagsenter og bolig - tjenester som kommunen må samordne om de skal oppleves som helhetlige. Den videre diskusjonen konsentrerer seg om muligheter og utfordringer for samordningen når tjenestene, ansatte og brukere på ulike måter skal benytte digitale løsninger. Det vil fortsatt være flere enheter og virksomheter som er involvert i tjenesteleveransene til bruker. Dette medfører et behov for samordning og integrasjon av 
tjenester for å jobbe mot helhetlige tjenester (Axelsson \& Axelsson, 2006; Valentijn, Schepman, Opheij \& Bruijnzeels, 2013).

Dette kapitlet vil drøfte følgende spørsmål: 1) Hvilke utfordringer er digitaliseringen tenkt å løse? og 2) Hvordan påvirker digitalisering samordning av helse- og velferdstjenestene?

Nedenfor følger en presentasjon av bakgrunnsstoff, etterfulgt av en redegjørelse for metode. Spørsmålene ovenfor diskuteres deretter ved hjelp av henholdsvis policydokumenter og en litteraturstudie. Til sist følger en oppsummering.

\section{Bakgrunn}

Økt befolkningsvekst, en generell bedring av folkehelsen samt økt levealder gir utfordringer relatert til en aldrende befolkning med sammensatte og komplekse hjelpebehov. Samtidig er det knapphet på ansatte innenfor helse- og velferdstjenestene (Chidzambwa, 2013; Helse- og omsorgsdepartementet, 2014; NOU 2011:11), tjenester som gjennomgående er svært arbeidsintensive. Innføring av ny teknologi, både i hjemmet og på ulike nivåer av pleie- og velferdstjenester, kan være nødvendig for at samhandlingsreformen skal kunne realiseres. Behovet for teknologiske løsninger er forankret i et hovedpoeng i samhandlingsreformen: at en ikke vil kunne ivareta mange mennesker med pleie- og omsorgsbehov i kommunene uten at en tilfører større kapasitet i støttefunksjoner innenfor pleie- og velferdstjenestene.

Det er flere begreper som benyttes om IKT-systemer og digitale løsninger i offentlig forvaltning og tjenesteyting, blant annet e-forvaltning, velferdsteknologi og eHelse. E-forvaltning refererer til bruk av digitale løsninger for å løse oppgaver i offentlig forvaltning. Det innebærer at «e-forvaltning [...] betegner de ulike organisasjonsformene initiativene er ment å resultere i» (Tranvik, 2008, s. 9). Velferdsteknologi viser til «teknologisk assistanse som bidrar til økt trygghet, sikkerhet, sosial deltakelse, mobilitet og fysisk og kulturell aktivitet» (NOU 2011:11, s. 100). Begrepet brukes i noen sammenhenger om løsninger rettet mot arbeidsorganisering innen helse- og velferdstjenestene, som logistikkløsninger og pasientvarslingsanlegg. eHelse er et samlebegrep for IKT i helse- og omsorgstjenestene. Velferdsteknologi kan grense til eller overlappe med 
IKT i helse- og kommuneforvaltningen og på hjelpemiddelområdet (Helse- og omsorgsdepartementet, 2012). I dette kapitlet diskuteres forhold relatert til velferdsteknologi og eHelse, IKT som beslutningsstøtte og digitaliserte arbeidsmetoder.

Bruk av digitale teknologiske løsninger medfører i seg selv både muligheter for og krav om økt samordning og sambruk. Teknologi fremstilles ofte som et nøytralt virkemiddel, men den fremmer bestemte handlinger og praksiser gjennom hvordan den utvikles og implementeres (Sprogøe \& Jørnøe, 2015). Teknologiske systemer påvirker arbeidsmåter, informasjonstilgang, kommunikasjon, samordning, maktforhold samt rolle- og oppgavefordeling. Digitalisering kan videre skape utfordringer med hensyn til hvordan tjenesteytere kan utføre sine oppgaver og ivareta sitt ansvar. Det kan være oppgaver knyttet til det å ivareta arbeidsflyt i pasientforløp, sikre tilstrekkelig beslutningsgrunnlag for å fatte vedtak om tjenester, eller til å følge opp brukere med komplekse behov som gjerne mottar tjenester fra flere ulike tjenestesteder samtidig.

Samordning viser til prosesser der man ser ulike deler i sammenheng, prioriterer og tilpasser dem til hverandre. Innenfor helse- og velferdstjenestene vil det å skape helhetlige tjenester for brukere med sammensatte og komplekse hjelpebehov være mer enn summen av de ulike tjenestetilbudene som ytes. Det er tjenester som er planlagt og tilpasset hverandre slik at de utfyller hverandre i samspillet mot et felles mål (Hudson, 2004). Dette kan skje på ulike måter, som gjennom oppgavefordeling og ulike former for samarbeid med ulik grad av kompleksitet (Andersson, Ahgren, Axelsson, Eriksson \& Axelsson, 2011).

I helse- og velferdssektoren vil IKT kunne være et verktøy for å støtte arbeidsprosesser. Da er det ikke teknologien i seg selv som er i fokus, men hva man kan gjøre annerledes med teknologi. Det viser gjerne til forventinger om en bedre eller til og med «riktigere» måte gjøre ting på. IKT blir et verktøy for rasjonalisering, og tilrettelegger for videre modernisering av offentlig forvaltning (Margetts, 2003). Digitale systemer gjør det i større grad mulig å formalisere regler og prosedyrer, noe som igjen åpner for forsterket objektiv rasjonalitet i beslutningsprosesser som saksbehandling av helse- og velferdstjenester, med andre ord en fortsettelse av weberske rasjonaliseringsprosesser. 
Digital-era governance (DEG) som perspektiv på reformering og modernisering av offentlig sektor viser til den betydningen IKT og IKTsystemer har for organiseringen av offentlige tjenester, og for hvordan tjenester leveres til borgere og brukere. DEG kan sammenstilles i tre tema: reintegrasjon, behovsdrevne helhetlige tjenester og digital endring i offentlig forvaltning (Dunleavy, Margetts, Bastow \& Tinkler, 2006). Digitalisering presser på for å reintegrere tjenester ved å trekke tilbake desentraliserte funksjoner fra lokale til sentrale enheter. Dette skal hindre dobbeltarbeid, og kan dermed redusere kostnader som er forbundet med å ha flere enheter. I tillegg kan man få økt kontroll med forbruket. Med brukerdrevne helhetlige tjenester søker man å endre forholdet mellom myndighetene og borgerne. Endringer, her i form av digitalisering og i henhold til ideer innenfor DEG, vil kunne være et svar på krav om innsparinger. Forbedring av tjenestene er sentralt, og organisering av helhetlige tjenestetilbud rundt brukeres behov og bruken av one-stop-prosesser (førstelinjetjenesten har tilgang på informasjon i sanntid) eller one-stop-shops (flere tjenester på ett sted) får økt utbredelse (Dunleavy mfl., 2006; Lægreid \& Rykkja, 2015; Margetts \& Dunleavy, 2013).

\section{Metode}

Det første spørsmålet, hvilke utfordringer digitalisering er tenkt å løse, blir besvart ved å gjennomføre en tematisk analyse av policydokumenter (Braun \& Clarke, 2014).

Nasjonale policydokumenter for perioden 2006-2018 er valgt ut som datamateriale. Det starter med St.meld. nr. 17 (2006-2007) Et informasjonssamfunn for alle, som er den første stortingsmeldingen med betydning for digitaliseringspolitikken. De øvrige dokumentene er valgt ut med tanke på at de omhandler bruk av digital teknologi i offentlig sektor og organisering av helse- og velferdstjenester.

Formålet med tematisk analyse er å identifisere betydingsmønstre i data. Tematisk analyse "provides a flexible and useful research tool, which can potentially provide a rich and detailed, yet complex, account of data» (Braun \& Clarke, 2006, s. 79). I tillegg til studiens problemstillinger 
er spørsmålene som styrer kodingen, viktige for utviklingen av koder i analysen (Braun \& Clarke, 2006).

Datamaterialet er analysert med utgangspunkt i følgende spørsmål:

- Hvem er aktørene?

- Hvorfor skal man ta i bruk digital teknologi?

- Hva er målet?

Dette har gitt to kategorier, henholdsvis forholdet mellom tjenestene og brukerne samt effektivitet, som også strukturerer diskusjonen nedenfor.

Det andre spørsmålet - hvordan påvirker digitalisering samordning og arbeidsorganisering - besvares ved å gjøre en litteraturstudie. Formålet med utvalget har vært å inkludere studier av både helse- og velferdstjenestene. Siden samordning og arbeidsorganisering er tema som skal diskuteres, er det viktig at tidsskriftene ikke primært publiserer kliniske studier. Følgelig har jeg søkt i tidsskrifter hvor formålet er å publisere artikler om forskning på henholdsvis sosialt arbeid og helsetjenester samt praksis knyttet til disse. The European Journal of Social Work og The British Journal of Social Work er to sentrale tidsskrifter innen sosialt arbeid. BMC Health Services Research er et tidsskrift som formidler helsetjenesteforskning og i mindre grad vektlegger kliniske studier. Det samme gjelder Journal of Health Organization and Management. I litteratursøket er også snøballmetoden benyttet i datainnsamlingen (Grønmo, 2004) ved at litteratur som det er henvist til, var aktuell for kapitlets problemsstilling. Denne litteraturen har igjen ført til nye artikler.

\section{Utfordring som digitaliseringen skal løse}

Myndighetene har store forventinger til elektronisk beslutningsstøtte, digitale kommunikasjonsløsninger og velferdsteknologiske løsninger, og kan slik sett sies å være «teknologioptimister». Det er flere departement som fremmer et slikt syn og bidrar til politikkutformingen. Kommunalog moderniseringsdepartementet (som har tatt over mange av oppgavene til det tidligere Fornyings- og administrasjonsdepartementet) sier noe om i hvilken retning myndighetene ønsker at kommunene spesielt skal 
jobbe fremover. Dette kapitlet er avgrenset til å se på det som gjelder de kommunale helse- og velferdstjenestene. Her er også Helse- og omsorgsdepartementet, Helsedirektoratet og Direktoratet for eHelse sentrale aktør. Sammen med KS leder de to direktoratene Nasjonalt velferdsteknologiprogram. Arbeids- og sosialdepartementet er opptatt av at NAV skal ta i bruk stadig flere digitale og automatiserte tjenester. Presentasjonen nedenfor viser hvilke utfordringer og målsettinger disse aktørene fremsetter knyttet til bruk av digitale teknologiske systemer.

\section{Forholdet mellom tjenestene og brukerne}

Myndighetene argumenterer for at IKT-systemer vil kunne endre både brukernes og de pårørendes tilgang til informasjon samt deres kommunikasjon med forvaltningen og tjenesteyterne (Fornyings- og administrasjonsdepartementet, 2006). Én måte endringen kan skje på, er ved å legge til rette for at brukere og pårørende i større grad kan ha kontakt med hverandre og med tjenestene enn det de har i dag, som mer tradisjonelle tjenestemottakere (Helse- og omsorgsdepartementet, 2012; 2017). Brukere og pårørende kan betraktes som ubrukte ressurser som gjennom samproduksjon kan bidra til at tjenestene utvikles og leveres på en ny måte (Boyle \& Harris, 2009). Teknologiske løsninger er tenkt å bidra til at disse ressursene ikke lenger er ubrukte.

Bruk av digitale løsninger for å kommunisere med og informere brukere og pårørende skal bidra til at kommunene får «utnyttet kapasiteten» sin (Helse- og sosialdepartementet, 2017, s. 152). Dette vil med andre ord endre forholdet mellom bruker og helse- og velferdstjenestene ved å gi mulighet for avlastning av tjenestene samt et større ansvar til de pårørende. Samproduksjon, forstått som et system hvor tjenesteytere, brukere og pårørende samarbeider, kan ses som en måte utvikle bærekraftige helse- og velferdstjenester på (Askheim, 2016).

Hovedmålsettingene i Digital agenda for Norge er «en brukerrettet [...] offentlig forvaltning» med «deltakelse for alle» (Kommunal- og moderniseringsdepartementet, 2015, s. 11). Sentralt her er kravet om at brukerne skal settes i sentrum (Kommunal- og moderniseringsdepartementet, 2015). Brukersentreringen skal skje på ulike måter, blant annet gjennom 
involvering, veiledning og brukertilpasset språk (Digitaliseringsrundskrivet, 2017). Involvering av bruker - og pårørende - er en viktig demokratisk begrunnelse for samproduksjon, hvor brukernes og de pårørendes kompetanse, kunnskap og erfaringer anerkjennes. Involvering gir også mulighet for individuelle tilpasninger og vil dermed kunne bidra til kvalitet i tjenestene (Askheim, 2016; Bjørkquist \& Hansen, 2017). Men samtidig kan dette være urealistisk, fordi det ikke er gitt at virksomhetene, de ansatte og brukerne har samme mål eller felles interesser.

Myndighetene argumenter med at digitalisering vil kunne gi brukerne en mulighet til å «ta aktive valg» og «påvirke eget helsetilbud» (Helse- og omsorgsdepartementet, 2014, s. 83). Det vil kreve at helse- og velferdstjenestene har tilgang på IKT-verktøy som støtter arbeidsoppgavene de skal utføre. I tillegg må informasjonen følge brukeren. Videre argumenterer myndighetene for at digitale tjenester som er selvbetjente og hvor brukerne kan komme i dialog med tjenesteyterne, er et virkemiddel for brukermedvirkning.

NAV legger vekt på at brukerne vil forvente at flere av tjenestene blir automatiserte og selvbetjente. For å kunne avlaste NAV-ansatte må brukerne få dekket sitt behov for informasjon gjennom digitale løsninger (Arbeids- og sosialdepartementet, 2015). På nav.no er det utviklet ulike selvbetjeningsløsninger. I tillegg er saksbehandlingen for ordninger som barnetrygd og alderspensjon automatisert. Automatisering og digitalisering av tjenester og informasjonstilgang gir NAV mulighet til å styre kontakten med sine brukere, heter det. Det er da snakk om å utvikle selvbetjeningsløsninger som øker brukernes tilgjengelighet til NAV, samtidig som brukerne i større grad kan hente ut informasjon selv - uten å kontakte sitt lokale NAV-kontor. NAV-kontorene skal da kunne bruke mer av sin tid på brukerne og mindre på å gi informasjon. Digitalisering blir i meldingen (Arbeids- og sosialdepartementet, 2015) knyttet opp til det å skape en brukerrettet og effektiv forvaltning, hvor en av hovedprioriteringene er bruker i sentrum. Dette er i tråd med føringene i Digital agenda for Norge (Kommunal- og moderniseringsdepartementet, 2015).

Brukerdrevne tjenester kommer til uttrykk på flere måter, og i mange av dokumentene. Det skjer ved at man vektlegger at bruker skal kunne ta aktive valg, og at tjenestene skal utformes ut fra brukers behov og med 
bruker i sentrum (Dunleavy mfl., 2006; Margetts \& Dunleavy, 2013). Ressurser som er frigitt gjennom digitalisinger, skal brukes der det er behov for relasjoner og møter. Oppmerksomheten om tjenester for brukerne, og som er i tråd med deres målsettinger samt med deres medvirkning, er større i de senere stortingsmeldingene enn i de tidligere.

\section{Effektivitet}

Teknologi blir sett på som et tiltak for en mer effektiv og bedre produksjon av tjenester. Myndighetene er opptatt av at ressurser kan frigjøres, noe som man mener vil kunne bidra til å styrke velferdstilbudet samtidig som administrasjon blir redusert (Fornyings- og administrasjonsdepartementet, 2006).

I samhandlingsreformen vektlegger myndighetene behovet for nye teknologiske løsninger (etter hvert omtalt som velferdsteknologi) til brukere i eget hjem, i omsorgsboliger og i sykehjem. Dette er knyttet til et hovedpoeng i samhandlingsreformen, nemlig at man ikke vil kunne ivareta de mange brukerne med pleie- og omsorgsbehov i kommunene uten at man tilfører større kapasitet i støttefunksjoner innenfor pleie- og velferdstjenestene. Ettersom rekruttering av pleie- og omsorgspersonell vil være en knapphetsressurs i fremtiden, vil innføring av ny teknologi være nødvendig for at reformen skal kunne realiseres (Helse- og omsorgsdepartementet, 2008).

I den videre oppfølgingen av samhandlingsreformen er det et politisk mål at velferdsteknologi skal innlemmes i kommunenes ordinære tjenestetilbud. Gjennom opprettelsen av det nasjonale velferdsteknologiprogrammet (NVP), et program for utvikling og implementering av velferdsteknologi i helse- og omsorgstjenesten, viser Stortinget et ønske om å legge til rette for dette (Helse- og omsorgsdepartementet, 2012). Velferdsteknologiske løsninger kan bidra til økt trygghet for brukere og pårørende, slik at brukerne kan bo hjemme lenger. Arbeid med løsninger egnet for sykehjem og omsorgsboliger inngår også i oppdraget. Avlastning for pårørende blir også trukket frem som et viktig bidrag til at brukerne skal kunne bo hjemme lenger. I løpet av programperioden til Velferdsteknologiprogrammet har Helsedirektoratet gitt følgende 
anbefalinger for hvilke løsninger kommunene bør ta i bruk: varslingsog lokaliseringsteknologi, elektronisk medisinstøtte, elektronisk dørlås, digitalt tilsyn, oppgraderte sykesignalanlegg/pasientvarslingssystemer samt logistikkløsning for mer optimale kjøreruter og bedre kvalitet på tjenester (Mellting, 2017).

Også i NAV er man opptatt av at digitale løsninger skal benyttes der det kan gi mer hensiktsmessige arbeidsprosesser. Digital sykefraværsoppfølging trekkes frem som særlig viktig - fordi teknologiske løsninger i denne sammenhengen bidrar til å bedre oppfølging og dialog med brukere som har størst behov for det. I tillegg skal verktøyet effektivisere samhandling og informasjonsutveksling mellom den sykmeldte, arbeidsgiver, behandlere og NAV (NAV, 2017).

Som vist ovenfor er effektivisering et gjennomgående argument i de stortingsmeldingene som er presentert ovenfor. Digital endring skal med andre ord effektivisere tjenestene (Dunleavy mfl., 2006; Margetts \& Dunleavy, 2013). Omsorgstjenestene er arbeidsintensive, og myndighetene er opptatt av at behovet for tjenestene vil øke. Likeledes er det et stort press på NAV-kontorene og et tilsvarende behov for frigjøring av ressurser. Man anser det som nødvendig å jobbe med effektiviseringstiltak for å frigjøre ressurser, slik at viktige oppgaver kan prioriteres.

\section{Muligheter og utfordringer ved samordning av tjenestene}

Generelt handler mange av policydokumentene om effektivisering av tjenester og brukerorientering, og gir uttrykk for at forvaltningen er på brukernes side. Fra nasjonale myndigheters side er det stor tro på at digitale prosesser kan endre og fortrinnsvis forenkle folks hverdag og tjenesteutøverenes arbeidsdag. IKT brukes av mange som beslutningsstøtte i saksbehandling og profesjonsutøvelse. De ulike systemenes kompleksitet varierer, noe som har betydning for hvorvidt og hvordan systemene brukes. Noen utfordringer ved IKT-systemer er at de ikke nødvendigvis er egnet til sitt tiltenkte formål. Studier viser at de mangler funksjonalitet, er kostbare både i innkjøp og vedlikehold, og at de svekker heller enn bedrer effektiviteten (Ince \& Griffiths, 2011). 
Nedenfor følger en diskusjon av hvordan digitalisering påvirker samordningen av helse- og velferdstjenestene. Diskusjonen er strukturert etter fire sentrale forhold i litteraturen, henholdsvis kommunikasjon og informasjonsflyt, faglige perspektiver og standardisering, motstand og modifikasjoner samt skjermtid versus tid med bruker.

\section{Kommunikasjon og informasjonsflyt}

Monitoreringsteknologi kan på den ene siden være positiv for brukeren, med tanke på mestring og kontroll med egen sykdom. På den andre siden samles det inn og lagres informasjon om bruker, som skal forvaltes, benyttes i tjenestene og deles mellom tjenestene. KOLS-monitorering kan illustrere utfordringer knyttet til disse hensynene. I likhet med andre former for helsemonitorering kan KOLS-monitorering gi brukerne en opplevelse av mestring. Det er særlig fordi de kan bruke måleverdiene de selv registrerer, og kunnskapen om hva det betyr for egen dagsform, til for eksempel å opprettholde et visst aktivitetsnivå tilpasset dagsformen (Bjørkquist, 2015). Slik sett kan monitorering medføre en helsegevinst for noen KOLS-pasienter, fordi brukerne opplever økt trygghet og mestring basert på økt forståelse av og kontroll med sykdommen (May mfl., 2011).

Skal monitoreringsteknologi bidra til redusert fragmentering i tjenestene og lette samordningen, vil det kreve at helseopplysningene ikke lagres i egne systemer. Mange private aktører tilbyr applikasjoner for monitorering og oppfølging, også til friske brukere. For brukere som også har hjemmetjenester og/eller henvender seg til legevakten, vil samordning være en utfordring. Dette er fordi private aktører ikke inngår i informasjonsstrukturen og deler informasjon om sine pasienter/kunder med andre. Andre helsetjenester vil dermed ikke ha oppdatert informasjon om pasientens helsetilstand, med mindre vedkommende selv har dette med seg i elektronisk form i møte med legevakt eller andre, og kan orientere eller gi andre tilgang til registrerte data. Det at ulike databaser og registre ikke er koblet sammen, er en utfordring. Samordningen av tjenester blir krevende når en ikke har tilgang på informasjon eller kan være sikker på at informasjonen er oppdatert, for eksempel når det gjelder hvilke tiltak andre tjenester gir til brukeren. 
Meldingsutveksling av store datamengder, som bilder og noe pasientinformasjon, er vanskelig. Derfor vil det være mer hensiktsmessig at tjenesteytere får tilgang til informasjon i databaser der den er lagret, fremfor at informasjonen sendes rundt (Hauge, 2017). Informasjonsutveksling er blant de minst komplekse formene for samarbeid (Andersson mfl., 2011). Når informasjon ikke deles, er det grunnlag for å hevde at mulighetene for samordning av tjenestene også vil være utsatt. De ulike enhetene kan da operere innenfor sine egne grenser og bidra til å forsterke allerede eksisterende «siloer». Da kan det være behov for å etablere andre og mer komplekse samarbeidsformer enn informasjonsutveksling, som for eksempel møteplasser (Andersson mfl., 2011).

Det finnes eksempler på at digitale fagsystemer undergraver heller enn støtter arbeidet i førstelinjetjenesten. Studier innen barnevernet har vist hvordan slike systemer øker sjansen for feilaktige beslutninger - på bakgrunn av hvilken informasjon de bygger beslutningene på. Digitale fagsystemer kan bidra til at tjenesteutøvere endrer eller får begrensninger på hvilken type informasjon de benytter i sitt arbeid (Gillingham, 2018a). Flere systemer krever at ansatte legger inn og oppdaterer samme informasjon flere steder. Dette medfører dobbeltarbeid og blir sett på som sett på som en ekstra arbeidsoppgave (Gillingham, 2018b).

Det er også eksempler på at innføring av velferdsteknologi, her i form av digital trygghetsalarm, ikke løser allerede eksisterende utfordringer knyttet til fragmentering, manglende kommunikasjon og samarbeid (Bjørkquist, Forss \& Samuelsen, 2018). En tjeneste med digital trygghetsalarm involverer gjerne flere enheter og ulike tjenesteytere. Skal man kunne gi respons på utløste alarmer, vil det være et behov for informasjonsdeling og samordning med andre tjenester brukeren gjerne har. En vurdering av brukerens endrede behov for tjenester vil kreve informasjonsutveksling og samarbeid. Det kan for eksempel være når trygghetsalarmen ikke benyttes slik den er ment - hvor bruker utløser den ved andre behov enn de som vanligvis defineres som rent akutte (Bjørkquist mfl., 2018). Uten informasjonsdeling vil systemet ikke fungere som beslutningsstøtte for andre tjenester til brukeren. Det vil heller ikke bidra til samordning slik at bruker får helhetlige og integrerte tjenester. 
Generelt er det en utfordring for samordning og helhetlige tjenester at beslutningsstøtte ikke er integrert i journalsystemer, men at informasjon om brukeren finnes i mange ulike systemer - noen elektroniske og andre i papirform (Hauge, 2017). Når det gjelder helseregistre, er det ikke tillatt med dobbel dokumentasjon i henhold til pasientjournalloven og helseregisterloven (Christiansen mfl., 2017). Det betyr at dokumentasjon som ligger i et delt elektronisk helseregister, skal erstatte informasjon som ligger i interne systemer. Hensikten er å hindre at informasjon fra ulike kilder ikke stemmer overens.

Teknologiske løsninger virker inn på relasjonen mellom tjenesteyter og pasient. Tre forhold knyttet til teknologi trekkes frem: Det er nasjonale og kommunale krav om mer effektive tjenester, myndiggjøring av bruker og potensialet for overvåking som ligger i teknologien (Nakrem, Solbjør, Pettersen \& Kleiven, 2018). Et eksempel på en teknologisk løsning som skal effektivisere tjenesten, er digitale medisindispensere. Hensikten er å frigjøre tid for helsepersonell fordi tjenestemottaker får hjelp av en digital dispenser til å ta medisiner til rett tid. Det gjør at tjenesteyter vil ha færre besøk hos bruker, tid som i prinsippet kan benyttes på andre brukere eller til andre tjenester for de som har fått medisindispenser. Utfordringen er at det krever samordning av tjenestene og av arbeidet til tjenesteutøverne. Men slike hensyn synes å få lite oppmerksomhet i arbeidet med innføring av digitale medisindispensere, slik det er fremstilt i studien til Nakrem mfl. (2018).

Tilgangen på og bruken av informasjon er viktig når tjenester til bruker skal samordnes. Om informasjonen ikke er tilgjengelig eller ikke er oppdatert og gyldig, vil det vanskeliggjøre samordningen for brukere med komplekse behov, som gjerne mottar tjenester fra ulike enheter og instanser. Det kan også synliggjøre behovet for å samordne informasjonen i de ulike informasjonssystemene, slik at samme informasjon blir tilgjengelig for tjenesteutøvere som er involvert i beslutninger rundt samme bruker.

\section{Faglige perspektiver og standarder}

Det kan ses som en fordel å ta i bruk digitale fagsystemer som innlemmer et felles rammeverk for tjenesteutøvernes praksis. Bruk av IKT-systemet vil over tid styrke dette rammeverket. Et felles rammeverk kan lette 
samarbeid på tvers av ulike virksomheter og jurisdiksjoner samt bidra til at tjenenesteutøverne bruker samme språk når de er i kontakt med brukere (Gillingham, 2018b). Samtidig vil bruk av rammeverk i en elektronisk kontekst gi mindre rom for tjenesteutøverne til å legge inn ulike faglige perspektiver og praksiser. Standardene som ligger i rammeverket, vil kunne begrense det faglige handlingsrommet, og det vil kunne komme i konflikt med den selvstendigheten i yrkesutøvelsen som profesjonelle tjenesteutøvere har (Grimen, 2008). Standardene kan videre oppleves som en motsetning til individuelt tilpassede tjenester - og dermed også til faglige og profesjonelle målsettinger (Skjødt \& Sprogøe, 2014). Slik sett kan digitaliseringsprosesser åpne for en viss profesjonspessimisme, hvor de faglige utfordringene problematiseres. Dette kan også kobles til at profesjonelles skjønnsutøvelse vil kunne bli begrenset som følge av at beslutningsprosessen og interaksjonen er standardisert (Bovens \& Zouridis, 2002).

Uavhengig av om fagsystemer og rammeverk kommer i en digital form eller ikke, legger arbeidsfordeling og rutiner i seg selv begrensninger på den enkelte tjenesteutøverens beslutninger og handlingsrom (Christensen, Lægreid, Roness \& Røvik, 2009). Dette vil være en måte for organisasjonen å virkeliggjøre bestemte mål på, men det er ikke gitt at det er oppslutning om virksomhetenes mål, verken blant tjenesteutøvere eller -mottakere (Jacobsen \& Thorsvik, 2013).

I kommunenes arbeid med innføring av velferdsteknologi kan det være grunnlag for å hevde virksomhetenes mål har en mer fremtredende plass enn brukernes mål eller profesjonelle mål. Virksomhetenes mål består av ulike former for effektivitet, enten det er indirekte økonomiske innsparinger eller mindre tid brukt hos tjenestemottaker. Bedre tjenestekvalitet kommer gjerne litt lenger ned på listen, og brukers mål nevnes sjelden først. For å kunne forbedre tjenestene er det et behov for å utvikle de ansattes kompetanse innenfor velferdsteknologi. Denne kompetansen er også viktig for oppnå målsettinger om reduserte kostnader gjennom økt effektivitet (Barakat, Woolrych, Sixsmith, Kearns \& Kort, 2013), og vil samtidig være en indirekte måte å nå virksomhetens mål på.

Når effektiviteten i den enkelte virksomhet gis størst oppmerksomhet, vil det være en utfordring å yte helhetlige tjenester - fortrinnsvis med 
bruker i sentrum - også når tjenestene digitaliseres. Dette er fordi hver virksomhet først og fremst tar utgangspunkt i egen drift. Det kan være overlapp mellom ulike offentlige virksomheters mål i tilfeller hvor en gruppe brukere skal motta tjenester fra flere organisasjoner (Christensen mfl., 2009). Samordning kan innebære noen kostnader som virksomhetene ikke nødvendigvis påtar seg, selv om de har overlappende målsettinger for en gitt brukergruppe. Behovet for samordning er vesentlig, men ikke nødvendigvis prioritert (jf. Kommunal- og moderniseringsdepartementet, 2015). I samhandlingsreformen understrekes det at innføring av teknologi ikke er tilstrekkelig for å effektivisere og forbedre kvaliteten. Det er også nødvendig med «organisasjonsutvikling, endringer av rutiner og nye måter å samarbeide på for å oppnå effektivisering og kvalitetsforbedring» (Helse- og omsorsdepartementet, 20o8, s. 35). Felles budsjetter kunne være en måte å stimulere til nye måter å samarbeide på (Andersson mfl., 2011).

\section{Motstand og modifikasjoner}

Det finnes eksempler på at ansatte modifiserer et program når det tas inn i den enkelte virksomheten. Resultatet blir at man ikke jobber etter de «løsningene» som IKT-systemene foreslår (Bergschöld, 2016; Gillingham, 2018b). Innføring av elektronisk ruteplanlegger i hjemmetjenesten (VPR-løsning) er et eksempel på hvordan teknologien ikke brukes slik den er tenkt, og hvor man dermed heller ikke oppfyller formålet. Ruteplanlegging er en av Helsedirektoratets anbefalinger når det gjelder velferdsteknologi. Dette er en logistikkløsning for mer optimale kjøreruter og er rettet mot arbeidsorganisering. Hensikten er å redusere kostnadene ved at både tidsbruken på ruteplanlegging og reisetiden mellom tjenestemottakernes hjem går ned (Bergschöld, 2016). Tester har vist at så er tilfelle, men når systemet settes i drift, endres dette bildet. De ansattes atferd styres ikke bare av forhold utenfra, men også av krefter i organisasjonen. Slike krefter kan bidra til at ansatte bare til en viss grad endrer atferd, eller at endringer uteblir helt (Pierson, 2004; Thelen, 2003).

I arbeidet med å sette opp kjøreruter bruker programmet geodata for å angi veivalg og tidsrammer. Det har vist seg at den som har ansvar 
for å sette opp og planlegge kjøreruten i hjemmetjenesten, for eksempel teamleder, slår av geodata-funksjonen. Ansatte ser på muligheten for å lagre store mengder informasjon i VPR-løsningen som nyttig, og den blir også brukt (Bergschöld, 2016). Men når kjørerutene er fordelt på tjenesteyterne, bruker hver av dem opptil 30 minutter på å endre på dagens ruteplan før de reiser ut. I dette tilfellet ser vi at de ansattes atferd bare til en viss grad endres. Det kan forstås som at det finnes noen institusjonelle normer for kollektive praksiser, her hva som er en god kjørerute og hvordan man styrer dem, som bidrar til å forsinke eller modifisere endringen (Thelen, 2003). Slik som her, hvor man tilsynelatende tar i bruk nye digitale verktøy, men med en lokal tilpasning. Hvorvidt kostnader knyttet til planleggingstid og kjøretid blir redusert sammenlignet med praksis før innføringen av teknologi, er uklart. Men det er grunn til å anta at ansatte bruker mer tid på å endre rutene manuelt enn det man skulle forvente ut fra optimal bruk av teknologien.

Flere studier viser at systemene brukes ulikt, og at tjenesteutøverne ikke registrerer saker de jobber med på samme måte. Dette får konsekvenser for hvordan informasjonen kan brukes videre, ikke bare i saksbehandlingen. Det vanskeliggjør planlegging og kvalitetssikring, siden det kan hefte usikkerhet ved det statistiske materialet og data på aggregert nivå (Lagsten \& Andersson, 2018). Selv om systemene legger grunnlag for å standardisere tjenesteutøvernes vurdering, både når det gjelder hva som skal vurderes, og hvordan det skal gjøres, er det fortsatt rom for å bruke andre løsninger. Dette kan være løsninger som enten fungerer best for den enkelte, eller som utgjør en del av en kollektiv forståelse av hva som er bedre løsninger enn det systemet legger opp til. Institusjonelle normer kan fungere som motkrefter. Disse motkreftene svekker virkningen av endringer som skulle følge av standardene som ligger i de teknologiske løsningene (March \& Olsen, 2006; Pierson, 2004).

Nilsen, Dugstad, Eide, Gullslett og Eide (2016) har studert innføringen av digitalt nattilsyn ved hjelp av dørsensor og sengematte, og finner at dette skaper motstand hos de ansatte. Studien viser fire ulike former for motstand - organisatorisk, kulturell, teknologisk og etisk -, og disse har sitt utspring i opplevde trusler mot stabilitet, gruppeidentitet og tradisjonelle helse- og omsorgsverdier. Man kan vise til at innføring av 
velferdsteknologi skaper motstand mot kommunikasjon og mot deltakende prosesser (Nilsen mfl., 2016). Slik motstand vil blant annet kunne hindre deling av og tilgang til informasjon. Det at ansatte ikke utfører deler av arbeidsoppgavene sine, dog uten nødvendigvis å gjøre aktiv motstand, kan forstås som misbehaviour eller ulydighet (Ackroyd \& Thompson, 2003). Ansatte vegrer seg for å føye seg etter retningslinjer og krav, her hvordan teknologi skal brukes og digital informasjon deles. Slik ulydighet blant ansatte får konsekvenser for muligheten til å samordne tjenestene rettet mot bruker. Men også medvirkning og involvering av bruker kan bli vanskeliggjort av tjenesteutøverens vegring for å inngå i deltakende prosesser.

Generelt kan samordning vanskeliggjøres av at ansatte yter en eller annen form for motstand eller modifiserer tiltak som innføres, fordi de ikke vet hva som faktisk skjer i organisasjonen. Dette gjelder innføring av digitale løsninger så vel som andre tiltak og endringer.

\section{Skjermtid versus tid med bruker}

Tjenesteytere i sosialtjenesten kan bruke uforholdsmessig mye tid foran skjermen for å dokumentere, kommunisere og hente ut informasjon, tid man mener går på bekostning av tid med bruker (Lagsten \& Andersson, 2018). Leger i sykehus bruker også mer tid på skjermarbeid - både fordi det er et krav om dokumentasjon, men også fordi medisinske beslutninger tas i journalsystemet. Det innebærer at skjermtiden også er pasientrettet arbeid (Lotherington \& Obstfelder, 2015). Likevel kan det forstås som at legene har mistet kontroll over sin egen arbeidssituasjon, og at den faglige autonomien er svekket. I noen tilfeller kan det være uklart hvem man deler hvilken informasjon med (Ince \& Griffiths, 2011; Peckover, White \& Hall, 2008).

Når ansatte opplever at skjermtiden tar tid og oppmerksomhet bort fra andre oppgaver, kan det komme i strid med faglige verdier. Tjenesteyterne må da kompromisse med egne faglige normer for å møte kravene som ligger i bruk av digitale verktøy og systemer, og som da er organisasjonens krav og systemer (Ekeland, Steinstø \& Stefansen, 2011). Bruk av IKT-systemer i arbeidet kan også forstås ut fra en etisk dimensjon 
hos tjenesteytere (Peckover mfl., 2008). Det viser til dilemmaer knyttet til at ansatte bruker tid på å legge inn data om bruker, tid som i stedet kunne vært brukt direkte i møte og i klientarbeid, eller som utgjør ekstraarbeid.

\section{Oppsummering}

Følgende problemstillinger ble reist innledningsvis: Hvilke utfordringer er digitaliseringen tenkt å løse? og 2) Hvordan påvirker digitalisering samordning og arbeidsorganisering?

Digitalisering for å etablere mer effektive og kvalitativt bedre helse- og velferdstjenester dreier seg dels om nye IKT-baserte løsninger rettet mot arbeidsmåter og organisering av pasientbehandling. Det er da snakk om å kunne organisere arbeidet på en mer effektiv måte ut fra økonomiske og faglige hensyn. Videre handler det om velferdsteknologiske løsninger som støtter opp om den enkelte brukers daglige gjøremål, trygghetsopplevelse og behandling. Presset på tjenestene skal lettes ved å innføre digitale løsninger som frigjør ressurser, slik at disse kan settes inn der det er behov for å etablere relasjon og møter. Brukernes behov og mulighetene for aktive valg skal være sentrale i utviklingen av tjenestene. Samlet sett endrer dette forholdet mellom tjenestene og brukerne.

Helsedirektoratet har gitt noen konkrete råd knyttet til valg av velferdsteknologiske løsninger, basert på erfaringer fra utprøving i det nasjonale velferdsteknologiprogrammet. Digitaliseringens rolle og omfang innenfor lokale rammebetingelser i helse- og velferdstjenestene er likevel en stor utfordring. Forventingene til at fragmentering på helse- og velferdsområdet kan reverseres ved hjelp av digital teknologi som muliggjør informasjonsdeling og samordning på tvers av sektorer og virksomheter, er så langt ikke innfridd. Det er fortsatt et sterkt behov for samordning av tjenestene for brukere som har komplekse behov og mottar tjenester fra flere enheter, gjerne samtidig og over tid.

Det er mange av tiltakene som er diskutert ovenfor, som ikke nødvendigvis vil kunne sies å innebære en digitalisering, hvis vi med digitalisering forstår en transformativ endring i organisasjonen hvor IKT-løsninger ikke kun er et verktøy (Andersen \& Sannes, 2017; Breunig \& Skjølsvik, 
2017). På bakgrunn av de digitaliseringsprosessene som er gjennomført til nå, vil jeg hevde at det er et skille mellom NAV og helse- og omsorgstjenestene når det gjelder potensialet for å få samordnet tjenester til den enkelte bruker innenfor de ulike sektorene. Det synes som om digitaliseringen av arbeids- og velferdstjenestene i større grad blir samordnet, og at man deler informasjon innenfor ett NAV, selv om det er ulike kommuner og kontorer. Innenfor helse- og omsorgstjenestene - med et skille mellom kommunene med sitt lokale selvstyre og sektorinndeling på den ene siden og de regional helseforetakene på den andre, med ulike systemer og ulikt ansvarsområde - er samordning en stor utfordring, med eller uten digitalisering. Samordning mellom tjenester som NAV gir, og kommunale helse- og omsorgstjenester, er fortsatt vanskelig.

De ulike tjenestene har forskjellige digitale fagsystemer, journalsystemer, m.m. I tillegg har de ofte ulike målsettinger, for eksempel bruker versus virksomhet. Brukerne har flere tjenester som fortsatt ikke snakker sammen, eller som ikke nødvendigvis inkluderer bruker med hensyn til kartlegging og vurdering av tiltak. I de kommunale tjenestene det er vist til ovenfor, er det manglende - eller i beste fall mangslungne erfaringer fra effektivisering av tjenestene og bruker i sentrum. Intern motstand modifiserer de digitale systemene, og tjenesteytere opplever å bruke tid på skjermarbeid fremfor på direkte kontakt med bruker.

Generelt er mange av studiene som er gjennomgått, opptatt av å utforske forhold ved teknologi knyttet til bruker, til ansatte eller til forholdet mellom ansatte og bruker. Det er få studier på teknologi i organisasjonen. Her er det et tydelig forskningsbehov.

Behovet for ny teknologi innenfor den kommunale pleie- og omsorgssektoren er klart erkjent, men konkretiseringen av denne teknologien, dens rolle og omfang innenfor nye lokale rammebetingelser (de kommunale pleie- og velferdstjenestene), er en stor utfordring. Det knytter seg etiske utfordringer til anvendelse av teknologiske løsninger innenfor hjemmet eller i tjenester til pasienter, og møtet mellom ny teknologi og profesjonelt pleie- og omsorgsarbeid vil også innebære profesjonelle utfordringer. Innføringen av ny teknologi skjer i spennet mellom «teknologioptimister» og «profesjonspessimister», der de sistnevntes problematisering av faglige og etiske utfordringer - sammen med manglende 
kompetanse i å håndtere ny teknologi - ofte vil utgjøre barrierer for å ta i bruk det potensialet som teknologisk kunnskap representerer, slik et ensidig teknologisk perspektiv kan innebære.

\section{Referanser}

Ackroyd, S. \& Thompson, P. (2003). Organizational misbehaviour. London: SAGE Publications Ltd.

Andersen, E. \& Sannes, R. (2017). Hva er digitalisering? Magma, 2o(6), 18-24.

Andersson, J., Ahgren, B., Axelsson, S.B., Eriksson, A. \& Axelsson, R. (2011). Organizational approaches to collaboration in vocational rehabilitation - an international literature review. International Journal of Integrated Care, 11(4), 1-10. https://doi.org/s10.5334/ijic.67o

Arbeids- og sosialdepartementet (2015). NAV i en ny tid - for arbeid og aktivitet. (Meld. St. 33 (2015-2016)). Oslo: Arbeids- og sosialdepartementet.

Askheim, O.P. (2016). Samproduksjon som velferdssektorens kinderegg. Tidsskrift for omsorgsforskning, 2(01), 24-36.

Axelsson, R. \& Axelsson, S.B. (2006). Integration and collaboration in public health - a conceptual framework. The International Journal of Health Planning and Management, 21, 75-88. https://doi.org/10.1002/hpm.826

Barakat, A., Woolrych, R.D., Sixsmith, A., Kearns, W.D. \& Kort, H.S. (2013). eHealth technology competencies for health professionals working in home care to support older adults to age in place: Outcomes of a two-day collaborative workshop. Medicine 2 o, 2(2), e1o. https://doi.org/10.2196/med20.2711

Bergschöld, J.M. (2016). Domesticating homecare services: Vehicle route solver displaced. Nordic Journal of Science and Technology Studies, 4(2), 41-53. https:// doi.org/10.5324/njsts.v4i2.2184

Bjørkquist, C. (2015). Erfaringer med helsemonitorering for KOLS-pasienter. Nordisk tidsskrift for helseforskning, 11(2), 200-211.

Bjørkquist, C., Forss, M. \& Samuelsen, F. (2018). Collaborative challenges in the use of telecare. Scandinavian Journal of Caring Sciences. https://doi.org/10.1111/scs.12605

Bjørkquist, C. \& Hansen, G.V. (2017). Samproduksjon med pårørende til personer med ROP-lidelser. Tidsskrift for omsorgsforskning, 3(3), 194-203.

Bovens, M. \& Zouridis, S. (2002). From street-level to system-level bureaucracies:

How information and communication technology is transforming administrative discretion and constitutional control. Public Administration Review, 62(2), 174184. https://doi.org/10.1111/0033-3352.00168

Boyle, D. \& Harris, M. (2009). The challenge of co-production. London: New Economics Foundation. 
Braun, V. \& Clarke, V. (2006). Using thematic analysis in psychology. Qualitative Research in Psychology, 3. https://doi.org/10.1191/1478088706qpo630a

Braun, V. \& Clarke, V. (2014). What can "thematic analysis" offer health and wellbeing researchers? International Journal of Qualitative Studies on Health and Well-being, 9, 26152. https://doi.org/10.3402/qhw.v9.26152

Breunig, K.J. \& Skjølsvik, T. (2017). Digitalisering av kunnskapsarbeid; utvikling, hindringer og drivere i virtuelle advokatfirma. Magma, 2o(6), 63-73.

Chidzambwa, L. (2013). The social considerations for moving health services into the home: A telecare perspective. Health Policy and Technology, 2(1), 10-25. https:// doi.org/10.1016/j.hlpt.2012.12.003

Christensen, T., Lægreid, P., Roness, P.G. \& Røvik, K.A. (2009). Organisasjonsteori for offentlig sektor: instrument, kultur, myte. Oslo: Universitetsforlaget.

Christiansen, E.K., Skipenes, E., Hausken, M.F., Skeie, S., Østbye, T. \& Iversen, M.M. (2017). Shared electronic health record systems: Key legal and security challenges. Journal of Diabetes Science and Technology, 11(6), 1234-1239. https:// doi.org/10.1177/1932296817709797

Digitaliseringsrundskrivet (2017). Rundskriv H-7/17. Oslo: Kommunal- og moderniseringsdepartementet.

Dunleavy, P., Margetts, H., Bastow, S. \& Tinkler, J. (2006). New public management is dead - long live digital-era governance. Journal of Public Administration Research and Theory, 16(3), 467-494. https://doi.org/10.1093/jopart/muio57

Ekeland, T.-J., Steinstø, N. \& Stefansen, J. (2011). Klinisk autonomi i evidensens tid. Styringspolitiske utfordringer for klinisk praksis. Tidsskrift for velferdsforskning, 14(1), 2-14.

Fornyings- og administrasjonsdepartementet (2006). Eit informasjonssamfunn for alle. (St.meld. nr. 17 (2006-2007)). Oslo: Fornyings- og administrasjonsdepartementet.

Gillingham, P. (2018a). Decision-making about the adoption of information technology in social welfare agencies: Some key considerations. European Journal of Social Work, 21(4), 521-529. https://doi.org/10.108o/13691457.2017.1297773

Gillingham, P. (2018b). Developments in electronic information systems in social welfare agencies: From simple to complex. The British Journal of Social Work, bcyo14-bcyo14. https://doi.org/10.1093/bjsw/bcyo14

Grimen, H. (2008). Profesjoner og profesjonsmoral. I A. Molander \& L.I. Terum (Red.), Profesjonsstudier (s. 144-160). Oslo: Universitetsforlaget.

Grønmo, S. (2004). Samfunnsvitenskapelige metoder. Bergen: Fagbokforlaget. Hauge, H.N. (2017). Den digitale helsetjenesten. Oslo: Gyldendal Akademisk. Helse- og omsorgsdepartementet (2008). Samhandlingsreformen. Rett behandling - på rett sted - til rett tid. (St.meld. nr. 47 (2008-2009)). Oslo: Helse- og omsorgsdepartementet. 
Helse- og omsorgsdepartementet (2012). Morgendagens omsorg. (Meld. St. 29 (20122013)). Oslo: Helse- og omsorgsdepartementet.

Helse- og omsorgsdepartementet (2014). Fremtidens primorhelsetjeneste - norhet og helhet. (Meld. St. 26 (2014-2015)). Oslo: Helse- og omsorgsdepartementet.

Helse- og sosialdepartementet (2017). Leve hele livet. En kvalitetsreform for eldre. (Meld. St. 15 (2017-2018)). Oslo: Helse- og sosialdepartementet.

Hudson, B. (2004). Analysing network partnerships. Public Management Review, 6(1), 75-94. https://doi.org/10.1080/14719030410001675740

Ince, D. \& Griffiths, A. (2011). A chronicling system for children's social work: Learning from the ICS failure. The British Journal of Social Work, 41(8), 1497-1513. https://doi.org/10.1093/bjsw/bcro16

Jacobsen, D.I. \& Thorsvik, J. (2013). Hvordan organisasjoner fungerer (4. utg.). Bergen: Fagbokforlaget.

Kommunal- og moderniseringsdepartementet (2015). Digital agenda for Norge IKT for en enklere hverdag og økt produktivitet. (Meld. St. 27 (2015-2016)). Oslo: Kommunal- og moderniseringsdepartementet.

Lagsten, J. \& Andersson, A. (2018). Use of information systems in social work challenges and an agenda for future research. European Journal of Social Work, 1-13. https://doi.org/10.108o/13691457.2018.1423554

Lotherington, A.T. \& Obstfelder, A. (2015). Digitalisering av arbeidsflyt på sykehus - konsekvenser for legers arbeidshverdag. Nordisk Tidsskrift for Helseforskning, 11(1). https://doi:10.7557/14.3480

Lægreid, P. \& Rykkja, L.H. (2015). Organizing for “wicked problems” - analyzing coordination arrangements in two policy areas: Internal security and the welfare administration. International Journal of Public Sector Management, 28(6), 475-493. https://doi.org/10.1108/IJPSM-01-2015-0009

March, J.G. \& Olsen, J.P. (2006). The logic of appropriateness. I R.E. Goodin (Red.), The Oxford handbook of political science (s. 689-708). Oxford: Oxford University Press.

Margetts, H. (2003). Electronic government: A revolutions in public administration? I B.G. Peters \& J. Pierre (Red.), Handbook of public administration (s. 366-376). London: Sage Publications.

Margetts, H. \& Dunleavy, P. (2013). The second wave of digital-era governance: A quasi-paradigm for government on the Web. Philosophical Transactions of the Royal Society A, Mathematical, Physical, and Engineering Sciences, 371(1987), 20120382. https://doi.org/10.1098/rsta.2012.0382

May, C.R., Finch, T.L., Cornford, J., Exley, C., Gately, C., Kirk, S., Mair, F.S. (2011). Integrating telecare for chronic disease management in the community: What needs to be done? BMC Health Services Research, 11(1), 131-141.

Mellting, J.B. (2017). Andre gevinstrealiseringsrapport med anbefalinger. Oslo: Helsedirektoratet. 
Nakrem, S., Solbjør, M., Pettersen, I.N. \& Kleiven, H.H. (2018). Care relationships at stake? Home healthcare professionals' experiences with digital medicine dispensers - a qualitative study. BMC Health Services Research, 18(1), 26. https:// doi.org/10.1186/s12913-018-2835-1

NAV (2017). Årsrapport 2017. Oslo: Arbeids- og velferdsdirektoratet.

Nilsen, E.R., Dugstad, J., Eide, H., Gullslett, M.K. \& Eide, T. (2016). Exploring resistance to implementation of welfare technology in municipal healthcare services - a longitudinal case study. BMC Health Services Research, 16(1), 657. https://doi.org/10.1186/s12913-016-1913-5

NOU 2011:11. Innovasjon i omsorg. Oslo: Helse- og omsorgsdepartementet.

Peckover, S., White, S. \& Hall, C. (2008). Making and managing electronic children: E-assessment in child welfare. Information, Communication \& Society, 11(3), 375-394. https://doi.org/10.1080/13691180802025574

Pierson, P. (2004). Politics in time: History, institutions, and social analysis. Princeton, N.J.: Princeton University Press.

Schartum, D.W., Jansen, A. \& Tranvik, T. (2017). Digital forvaltning - en innføring. Juridiske, informatiske og organisatoriske aspekter. Bergen: Fagbokforlaget.

Skjødt, U. \& Sprogøe, J. (2014). Anerkendelse i professionsfaglig ledelse. Tidsskrift for Arbejdsliv, 16(1), 83-97. https://doi.org/10.7146/tfa.v16i1.108956

Snellen, I. (2002). Electronic governance: Implications for citizens, politicians and public servants. International Review of Administrative Sciences, 68(2), 183-198. https://doi.org/10.1177/0020852302682002

Sprogøe, J. \& Jørnøe, R.L.V. (2015). Introduktion av velfærdsteknologi i professionel praksis. I K.K. Eriksen, M. Hansbøl, N.H. Helms \& M. Vestbo (Red.), Velfoerd, teknologi og loering i et professionsperspektiv (s. 49-63). Sorø: UCSJ Forlag.

Thelen, K. (2003). How institutions evolve: Insight from comparative historical analysis. I J. Mahoney \& D. Rueschemeyer (Red.), Comparative Historical Analysis in the Social Sciences (s. 208-240). Cambridge: Cambridge University Press.

Tranvik, T. (2008). Digital teknologi og organisasjonsendring: studier av offentlig og frivillig sektor. Bergen: Fagbokforlaget.

Valentijn, P.P., Schepman, S.M., Opheij, W. \& Bruijnzeels, M.A. (2013). Understanding integrated care: A comprehensive conceptual framework based on the integrative functions of primary care. International Journal of Integrated Care, 13(1). https://doi.org/10.5334/ijic.886 

KAPITTEL 8

\title{
Bedre tverrfaglig innsats - styrket tverrsektorielt samarbeid om utsatte barn og unge?
}

\author{
Marit K. Helgesen \\ Avdeling for helse og velferd, Høgskolen i Østfold
}

\begin{abstract}
Sammendrag: Helsedirektoratet og åtte kommuner har utarbeidet Bedre tverrfaglig innsats (BTI), et digitalt verktøy for å sikre at aktuelle tjenesteenheter og profesjonelle i kommuner gjennomfører samarbeid om utsatte barn og unge. Observasjoner viser imidlertid at BTI ikke i tilstrekkelig grad inngår i styring og ledelse i kommunene. Enhetsledere kan forholde seg til sektoriserte statlige styringssignaler, og oppfatte at de har et valg om å bruke BTI. Handlingsveiledere er ikke oppdaterte, og sikrer dermed ikke at tjenesteenheter, medarbeidere og foresatte får lik informasjon. Det digitale verktøyet mister effektivitet i konsultasjoner mellom tjenesteenheter i kommunen og med foresatte. For kommuner er det utfordrende å satse på utvikling og implementering av BTI og samtidig opprettholde kunnskapsnivået hos medarbeidere om andre tjenesteenheter og tiltak, samt om tverrsektorielt og -profesjonelt arbeid. Det ser også ut til at kommunene strever med å få BTI til å bli et verktøy som forenkler beslutninger om og gjennomføring av tjenesteyting knyttet til tidlig innsats for utsatte barn og unge.
\end{abstract}

Nøkkelord: BTI, kommuner, tjenester, barn og unge, styring, organisasjon, samordning

\section{Innledning og bakgrunn}

Denne artikkelen handler om et verktøy for tverrprofesjonelt og -sektorielt samarbeid horisontalt mellom tjenesteenheter i kommuner og vertikalt mellom kommuner og spesialisthelsetjenesten, eventuelt private og frivillige aktører. Verktøyet skal forenkle beslutninger om og tjenesteyting i gjennomføringen av tidlig innsats for utsatte barn og unge og deres

Sitering av dette kapitlet: K. Helgesen, M. (2019). Bedre tverrfaglig innsats - styrket tverrsektorielt samarbeid om utsatte barn og unge?. I C. Bjørkquist \& M. Jerndahl Fineide (Red.), Organisasjonsperspektiv på samordning av helse- og velferdstjenester (s. 193-214). Oslo: Cappelen Damm Akademisk. https://doi. org/10.23865/noasp.66.ch8.

Lisens: CC BY 4.0 
familier. Verktøyet heter Bedre tverrfaglig innsats. Det er også godt kjent som BTI, og er utviklet av Helsedirektoratet i samarbeid med åtte kommuner.

Det er mye kunnskap om hvordan utfordringer barn og unge utsettes for i oppveksten, følger dem livet ut. Barn og unge som har negative erfaringer som omfatter fattigdom, omsorgssvikt og vold, vil oftere enn andre oppleve dårlig helse i livsløpet. De er i større grad enn andre utsatt for å utvikle diabetes og luftveissykdommer, samt for å få slag og hjertesykdommer. Barn som vokser opp med foreldre som har rusrelaterte problemer, har en større risiko enn andre for selv å debutere tidlig med rus, og for å utvikle vedvarende rusrelaterte utfordringer. Barn og unge som lever med utfordringer som dette, er dessuten mer utsatt for å oppleve depresjon, og de har dårligere selvopplevd mental helse enn andre. De har også dårligere akademiske prestasjoner enn andre barn og unge (Marmot, 2015; Raninen, Elgán, Sundin \& Ramstedt, 2015). Andre determinanter som er bestemmende for hvordan barns psykiske helse utvikler seg, er sosioøkonomisk status, kjønn, etnisitet og familiestruktur (Stenmark, Bergström, Hägglöf, Öhman \& Petersen, 2015). Utfordringer - både sosiale og andre - har en tendens til å akkumulere seg. Dårlig utvikling tidlig i livet medfører gjerne dårligere skoleprestasjoner. Mange barn og unge får dermed ikke muligheten til å ta ut sitt fulle potensial i utdanning og arbeidsliv. Dette nedfeller seg i færre tilgjengelige muligheter på arbeidsmarkedet, noe som i sin tur påvirker inntekt og levekår senere i livet (Power \& Kuh, 2006).

Ut fra tilgjengelig kunnskap om slike forhold har Helsedirektoratet satset på å styrke kommunenes arbeid med tidlig innsats for barn og unge, og i 2007 ble det laget et forslag til nasjonal strategi for tidlig intervensjon overfor barn og unge som var utsatt for negative virkninger av rus (Helsedirektoratet, 2007). Utredningen pekte på at det er lite kunnskap om hvor stor denne risikogruppen er, altså hvor mange barn og unge som lever utsatt for rus, om hva som er tegn på utsatthet hos denne gruppen, samt om hva som er gode intervensjoner i gjennomføringen av tidlig innsats. Videre pekte den på at de viktigste arenaene for å identifisere utsatte barn og unge er de arenaene der de ferdes, og hvor foreldre er synlige, eller arenaer der «ungdom i sviktsonen» ferdes. Offentlige tjenester 
som barnehage, skole, SFO, helsetjenesten og fritidsklubber er tjenester det bør rettes oppmerksomhet mot, i tillegg til det offentlige rom. Dette gir kommunenes profesjonelle medarbeidere en sentral rolle i arbeidet med å identifisere utsatte barn og unge samt gjennomføre tidlig innsats. Utredningen retter oppmerksomhet mot enkelte profesjonelles forståelse av eget mandat for inngripen og deres handlingskompetanse, samtidig som det pekes på viktigheten av samordning og koordinering av innsatser i hjelpeapparatet knyttet til å yte tjenester til barn og unge det interveneres overfor (Helsedirektoratet, 2007). Kommunen som organisasjon og tilretteleggingen for arbeidet med tidlig innsats behandles ikke like grundig i utredningen. Dette ble løftet fram da et landsdekkende tilsyn i 2008 viste at kommuner ikke hadde rutiner for at tjenesteenheter kunne samarbeide godt om utsatte barn og unge. Hvis de hadde rutiner, ble disse ikke fulgt (Helsetilsynet, 2009).

NOU 2017:12 «Svikt og svik. Gjennomgang av saker hvor barn har vært utsatt for vold, seksuelle overgrep og omsorgssvikt» gikk inn i en del konkrete og grove saker om vold, overgrep og omsorgssvikt, og viste tydelig hvor fatalt det kan være for barn når det ikke fanges opp at de lever i en utsatt situasjon. Familiene i de fleste sakene som ble gjennomgått, mottok oppfølging fra flere offentlige tjenester uten at barnas alvorlige livssituasjon ble registrert. Samtidig pekes det på at ansvaret for å fange opp barn og unges situasjon påligger alle tjenester barn er i kontakt med, ikke bare barnevernet. Alle nevnte arenaer der barn og unge ferdes, kan dermed involveres. Utredningen aktualiserte det arbeidet Helsedirektoratet har gjennomført med BTI.

Denne artikkelen belyser om BTI vil kunne forenkle beslutninger om og tjenesteyting i gjennomføringen av tidlig innsats overfor barn og unge. For å diskutere dette stilles det tre spørsmål:1) Hva er de organisatoriske betingelsene for tverrsektorielt og -profesjonelt samarbeid i kommunene? 2) Hvordan utformes tverrsektorielt og -profesjonelt arbeid knyttet til BTI, og hvilken kunnskap har medarbeidere om dette i egen organisasjon? 3) Medfører digitaliseringen at det blir transparens i det tverrsektorielle og -profesjonelle arbeidet med BTI?

Artikkelen er i det videre bygget opp som følger: I neste avsnitt presenteres BTI nærmere, dernest presenteres metoden. Deretter følger tre 
avsnitt der jeg går nærmere inn på spørsmålene som er stilt over. Til sist følger oppsummering og konklusjon.

\section{Nærmere om BTI}

BTI er en modell for samhandling som skal sikre at profesjonelle yrkesutøvere og enheter samarbeider om utsatte barn og unge. Den inneholder fire elementer: 1) Handlingsveileder, et dokument som skal veilede medarbeidere i arbeidet med barn og unge, og spesielt i det tverrsektorielle arbeidet. Veilederen kan beskrive samarbeid med foresatte, og hvordan det kan skapes en felles forståelse av en gitt problemstilling. Den kan videre beskrive samarbeid over enhetsgrenser og koordinerende møter, samt hva som er innslagspunktet for å sette i gang tiltak innenfor rammen av BTI. 2) Stafettlogg, et dokument som skal følge barn og unge, eventuelt familier, som får ekstra innsatser. Alle involverte yrkesutøvere og tjenester, samt foresatte og barn og unge, skal ha tilgang til den. Disse to delene av verktøyet er digitalisert. 3) Det anbefales at det etableres en «stafettholder. Dette er en koordinatorfunksjon som sørger for at én person har hovedansvaret for å følge én sak. Vedkommende kan også få ansvaret for å føre stafettloggen, samt være barnets, den unges eller familiens kontaktperson overfor kommunen. At det er en anbefaling, kan bety at det ikke alltid vil oppnevnes en stafettholder. 4) Koordinerende team eller møte som skal samordne/diskutere felles handling for enheter og profesjonelle som blir involvert i arbeidet (Helsedirektoratet, u.å.). BTI kan brukes uavhengig av koordineringsverktøy som individuell plan eller ansvarsgrupper, og den kan brukes i stedet for eller i tillegg til slike verktøy. Det vil si at BTI er en modell som også er nivåoverskridende; den kan benyttes på både individ- og systemnivå.

Modellen har fire nivåer. På nivå o avklares det om en gitt observasjon av et barn eller en ungdom gir grunn til bekymring. Hvis observasjonen faktisk gir grunn til bekymring, kan løsningen finnes innenfor egen tjeneste. Å finne løsninger innenfor den tjenesten der observasjonen først gjøres, er arbeid på nivå 1. På nivå 2 samarbeider den tjenesten der observasjonen er gjort, med én annen tjeneste for å gjennomføre intervensjoner for barn og unge og deres familier. Barnevernet kan involveres her. 
På nivå 3 er det tre eller flere tjenester som samarbeider. Da har observasjonen manifestert seg i en alvorlig bekymring, og det samarbeides mellom flere enheter på kommunalt nivå og ev. med andrelinjen og private/ frivillige aktører. BTI er altså en plattform for å fatte beslutning om samt gjennomføre tverrsektorielt og -profesjonelt arbeid med intervensjoner. Den er altså ikke i seg selv en intervensjon. Modellen sier hvordan prosessen med å ta opp, snakke om, diskutere, fatte beslutning om, iverksette samt følge opp intervensjoner for barn og unge eller familier det knyttes bekymring til, kan organiseres, samt hvilke prosedyrer og rutiner som kan eller bør utvikles for å gjennomføre intervensjoner.

\section{Metode}

Det er åtte kommuner som har samarbeidet med Helsedirektoratet om å utvikle og tilpasse BTI til norske forhold. Disse er spredd geografisk, de varierer i størrelse samt når det gjelder politisk og administrativ organisasjon. Det varierer også hvor langt de er kommet i arbeidet med å utvikle BTI, hvor godt arbeidet er forankret på ulike nivåer i kommunen, og hvilke tjenesteenheter og yrkesgrupper som involveres. Samarbeidskommunene dokumenterer selv sitt arbeid med BTI, men Helsedirektoratet har gjennomført tre surveyer, i 2012, 2015 og 2018, for å følge arbeidet. Den første surveyen ble utviklet av Helsedirektoratet og preges av de behovene direktoratet hadde for kunnskap om faktorer som knytter an til tverrsektorielt og -profesjonelt arbeid for tidlig intervensjon for barn og unge på rusområdet. Analysen ble gjennomført av forfatteren. Surveyene som ble sendt i 2015 og 2018, er utviklet av Helsedirektoratet og forfatteren i samarbeid, mens analysene er gjennomført av forfatteren. I 2015 ble det lagt vekt på å følge opp spørsmål fra 2012, mens det i 2018 i stor grad ble stilt nye spørsmål, særlig knyttet til utbredelse og bruk av handlingsveileder og stafettlogg. Noen spørsmål er likevel fulgt opp, og blant dem finner vi tverrsektorielt og -profesjonelt arbeid. I denne artikkelen refereres det i all hovedsak til resultater fra surveyen som ble gjennomført i 2018, men resultatene derfra ses i sammenheng med resultater for tidligere år, der det er hensiktsmessig.

Samtlige tre ganger ble surveyen sendt til alle aktuelle medarbeidere og ledere i samarbeidskommunene, vel fem tusen respondenter hver gang. 
Kommunale prosjektledere informerte de aktuelle medarbeiderne i forkant om at surveyen ville bli sendt ut. Svarprosenten er på 34-36. Den er lav, men akseptabelt. Det er gjort strategiske overveielser i et par større kommuner der assistenter ikke er bedt om å svare på undersøkelsen. Over 50 prosent av dem som har svart på undersøkelsen i 2018, arbeider i skole, 18 prosent $\mathrm{i}$ offentlige og ni prosent i private barnehager, mens det er fem prosent som arbeider i barnevern, tre prosent i helsestasjon og PPT, samt at to prosent av dem som har svart, arbeider i skolehelsetjenesten.

Det er gjennomført intervjuer med prosjektledere eller ansvarshavende for BTI i samarbeidskommunene, i alt åtte intervjuer. Der ble det stilt spørsmål om kommunal forankring og organisering av BTI, om tverrsektorielt og -profesjonelt, samt om arbeidet med og betydningen av at handlingsveileder og stafettlogg er digitalisert. Intervjuene er gjort over telefon, og de varte ca. 30 minutter. Den siste surveyundersøkelsen ble gjennomført i perioden januar til april 2018, mens intervjuene ble gjennomført i april og mai samme år. For en fullstendig oversikt over gjennomføring av undersøkelsene, se Helgesen, 2013, 2015 og 2018. I analysen benyttes sitater fra intervjuene, de er merket med intervju og nummer. Det er også benyttet sitater som er kommentarer i surveyundersøkelsen. Fordi undersøkelsen er anonym, er disse ikke merket.

\section{Organisatoriske betingelser for tverrsektorielt og -profesjonelt arbeid}

Kommunal politisk og administrativ organisering er i stadig endring. Trenden for den administrative organiseringen er at kommuner endrer fra en flat struktur eller en tonivåmodell, der styringslinjen går direkte mellom enhetsleder og rådmann, til organisasjonsformer med ett eller flere mellomledd mellom enhetsledere og rådmann (Monkerud, Indset, Stokstad \& Klausen, 2016). Det er også en trend at det styres etter en nettverkstankegang der «enforced self-regulation», eller påtvunget selvstyring, er et viktig kjennetegn (Dent mfl., 2007). Altså at organisasjoner, deres ledere og profesjonelle medarbeidere tilpasser seg utenforliggende ofte statlige - krav, mer eller mindre frivillig. 
Tonivåmodellen var en periode populær i kommunene, blant annet fordi den ble antatt å underlette koordinering og samarbeid ved at den tillot delegering av myndighet, $i$ vårt tilfelle fra rådmann til enhetsledere. Om lag samtidig med at dette, var det også prosesser med det som kalles myndiggjøring av profesjonelle medarbeidere, og som kunne gi dem frihet til selv å fatte beslutninger, f.eks. om det var nødvendig å sette i gang samarbeid i bestemte saker. Dvs. at beslutninger om å gjennomføre tverrprofesjonelt, men også tverrsektorielt arbeid - altså arbeid på tvers av profesjonelle disipliner og tjenesteenheter i kommunene - ble delegert til de profesjonelle selv. I tonivåmodeller har enhetsledere vanligvis mer delegert myndighet knyttet til økonomi, fag og personell enn de har i trenivåmodeller (Oppedal, Stigen \& Laudal, 2002), og de kan fatte autonome beslutninger på disse områdene. I det lange løp har det vist seg at organisasjonsformen fremmet organisatorisk fragmentering og bidro til å skape såkalte «siloer», og at den dermed vanskeliggjorde en av utfordringene i kommunal organisering som den ble sett som løsningen på, nemlig arbeid på tvers mellom sektorer og tjenester i kommunene (Peters, 2015; Røvik, 1998). De profesjonelles utdanning og egenorganisering legger viktige betingelser for hvordan arbeidsoppgavene deres kan og skal utføres (Døving, Elstad \& Storvik, 2016), men også styringssignaler fra statlig og kommunalt nivå legger slike betingelser. Kommunale tjenester, det operative nivået der profesjonelle benytter sin kunnskap for å løse arbeidsoppgaver, får dermed signaler for hvordan tjenester bør ytes fra ulike steder.

Samtidig styrer og leder selvfølgelig kommunen selv sin virksomhet. Styring handler om hvordan atferd i kommuneorganisasjonen kan påvirkes ved å endre de økonomiske og administrative rammebetingelsene, det vil si ressurser som økonomi, autoritet, fag og organisasjon (Røiseland \& Vabo, 2016). Styring gjennomføres av en kommunes politiske og administrative toppledelse - og innebærer at det fattes strategiske beslutninger knyttet til planlegging og budsjettering for de ulike enhetene hver for seg, men også for kommunen samlet. Styringslinjen går via de ulike ledelsesnivåene til enhetsledere og medarbeidere. Ledelse innebærer at atferd i organisasjonen påvirkes av personorienterte aktiviteter, og at relasjoner mellom mennesker står sentralt. Det defineres som et prosessuelt fenomen (Røiseland \& Vabo, 2016). Ledelse gjennomføres på alle nivåer i den 
kommunale styringslinjen, men enhetslederne i de kommunene som har en tonivåmodell, har et større handlingsrom for å opptre autonomt og utøve ledelse enn det enhetsledere i andre typer kommuner har.

I dette datamaterialet er det to kommuner som har en såkalt flat struktur, der tjenesteenheter/enhetsledere rapporterer direkte til rådmannen, én kommune har det for sitt oppvekstområde, og én kommune har nettopp endret sin organisasjon fra to til tre nivåer. De andre har en form for trenivåmodell med kommunalsjef eller lignende, mens én kommune har sektormodell.

Surveyresultatene viser at det er en utfordring å forankre BTI, først og fremst hos rådmannen og på politisk nivå, men også hos kommunalsjef og hos ledere i de aktuelle tjenesteenhetene. 61 prosent av lederne som svarte på surveyen (343), mener at BTI er forankret hos enhetsledere, altså hos dem selv; 23 prosent mener det er forankret hos rådmenn, og 40 prosent mener det er forankret hos kommunalsjef (Helgesen, 2018). I kommentarer og i intervjuer ble det understreket at det er utfordrende å forankre BTI i enkelte tjenesteenheter. En surveyrespondent som ikke nødvendigvis er leder, uttrykte seg på denne måten:

Mitt inntrykk er at man ofte møter stor motstand [fra de] som hevder seg fritatt fra å ta i bruk en elektronisk logg. Kan bli mye dobbeltarbeid, dersom flere instanser i et samarbeidsnettverk nekter å ta i bruk loggen og ønsker informasjon på siden.

En annen surveyrespondent som trolig er leder i skolen, påpekte følgende $i$ en kommentar:

Kommunens enhetsledere innen oppvekst opplever BTI som et verktøy som verken letter samarbeidet eller er tidsbesparende for foresatte, ansatte eller andre involverte instanser. Ved min skole har vi prøvd det ut i flere saker og konkluderer hver gang med at skolens interne systemer er bedre, og den samme tilbakemeldingen får vi fra foresatte.

I ett intervju ble det sagt slik:

Jeg er ikke akkurat fornøyd med forankringen i kommunen. Jeg tenker - det er et politisk vedtak. Det er greit. Så er det et problem med ledere som ikke følger opp politiske vedtak. (Intervju 3) 
Det ble altså pekt på at det ble utøvd motstand mot BTI, men det ble også uttrykt håp om at en endring fra tonivå- til trenivåmodell i den kommunale organisasjonen skulle endre enhetslederes holdning til BTI. Ledere vil dermed i større grad innordne seg den politikken kommunen hadde fattet beslutning om at den skulle føre i forbindelse med tidlig innsats. Motstanden ble også tolket dit hen av respondenter på surveyen, at verktøy som har sitt utgangspunkt i helsesektoren, ikke nødvendigvis har legitimitet $\mathrm{i}$ andre sektorer og tjenesteenheter.

Sitatet fra lederen i skolen peker på at BTI kommer i konkurranse med enten et verktøy eller et sett rutiner for samarbeid som lenge har vært brukt i skolen. Hvis det som skjer i den enkelte kommunes styringslinje, er utydelig, og BTI ikke er gjennomgående forankret på alle nivåer, f.eks. som en del av planer og budsjett, kan enhetsledere som har fått delegert myndighet og dermed opplever at de har et handlingsrom, la være å ta BTI i bruk. Da kan det tenkes at de heller tilpasser seg sektorspesifikke krav som kommer fra statlig nivå, f.eks. innenfor skolesektoren. Slike krav er kjente og innarbeidet, og silotenkningen kan medføre at enhetsledere noen ganger ikke ser gevinsten av å ha et felles system for tidlig innsats i alle kommunale tjenester. Ledere som oppfatter at de har et handlingsrom innenfor den kommunale styringslinjen, kan tenkes å heller ikke gjennomføre ledelsesaktiviteter som styrker BTI som det rådende verktøyet for samhandling blant medarbeidere. I barnevernet ble det opplevd av en surveyrespondent på denne måten:

Ut fra slik BTI og stafettloggen er presentert for ansatte, så ville det være naturlig at det skulle være opprettet en stafettlogg i en stor del av de sakene barneverntjenesten kommer inn i, eller at det opprettes rett etter at barneverntjenesten har startet sitt arbeid. Det har ofte vært bekymringer av økende grad og ulike tiltak FØR det meldes til barneverntjenesten. Det er ofte ikke stafettlogg i barnevernssaker i praksis.

For at barnevernet enkelt skal få informasjon, vil en stafettlogg være nødvendig, men det er altså ikke vedkommende respondents erfaring at det skjer i saker som oversendes til dem. Uten en logg fungerer ikke BTI som et effektivt verktøy eller en plattform for tverrsektorielt eller 
-profesjonelt arbeid. Fra kommentarer i surveyen ser det også ut til at det er konflikter mellom kommunale tjenesteenheter om hvem som skal etablere logg, og dermed ha ansvaret for å følge en sak. Et eksempel ble det pekt på av denne surveyrespondenten:

Det er utfordrende at flere av skolene ikke er kommet i gang med bruk av stafettlogg og tar lite ansvar som stafettholdere. Opplever at flere mener/tror dette er ansvar de kan/skal skyve over på helsearbeidere (helsesøster, fysioterapeut etc.).

Dette er altså en indikasjon på at det er domenekonflikter mellom kommunale tjenesteenheter og profesjoner, der noen aktører ikke vil ta ansvar for arbeidsoppgavene knyttet til BTI, og slipper det. Årsaken ser ut til å være sammensatt. For det første gis det trolig sterke styringssignaler vertikalt mellom statlige og kommunale tjenesteenheter angående sektorspesifikke arbeidsoppgaver og verktøy. For det andre vil selvstyring medføre at disse styringssignalene fungerer godt overfor enhetsledere som er opptatt av å gjøre en faglig god jobb. For det tredje medfører tonivåmodellen at det er delegert ansvar i den kommunale styringslinjen, og enhetsledere med delegert myndighet kan oppfatte at de har et større handlingsrom for å gjennomføre kommunale arbeidsoppgaver enn det enhetsledere som ikke har like mye delegert myndighet, har. Dette kan medføre en sterk sektorspesifikk oppmerksomhet på utfordringer knyttet til tidlig innsats, en oppmerksomhet som medfører at profesjonelle medarbeidere ledes til ikke å ta BTI i bruk. Domenekonfliktene består dermed av at det foregår en overføring av uønskede arbeidsoppgaver (Abbott, 1988) fra skole til f.eks. helsestasjon eller barnevern. Dette er en overføring av oppgaver som kunne vært unngått hvis det hele tiden var blitt fokusert sterkere på den kommunale styringslinjen, og på at den skulle tas i bruk for å gjennomføre et helhetlig tiltak i kommunene. Manglende tiltak i styringslinjen, og den ikkeintenderte overføringen av arbeidsoppgaver, er til hinder for tverrsektorielt og -profesjonelt arbeid overfor den gruppen av barn og unge som BTI skal fange opp. Disse utfordringene vil trolig være større i kommuner med en tonivåmodell på sin administrative organisering enn i andre kommuner. 


\section{Tverrsektorielt og -profesjonelt arbeid og kunnskap om det i egen organisasjon}

Enhetsnivå og enhetsledere framstår altså som sentrale forankringspunkter for BTI. Enhetsledere er de profesjonelles nærmeste ledere, og de kan antas å ha oversikt over enhetens kunnskap og kompetanse, de vet hva som trengs for å gjennomføre nye oppgaver, og de har myndighet til å kanalisere ressurser - som tid og personell - mot bestemte oppgaver. Enhetsledere har også oversikt over økonomien og kan ta stilling til om enhetene har ressurser til å inngå i samarbeidet. Over ble det vist til at BTI i noen kommuner ikke oppfattes som forankret på dette nivået, og det har utviklet seg domenekonflikter der ingen vil ha ansvaret for å opprette stafettlogg og dermed ta ansvar for saken.

En profesjons faglige identitet er avhengig av hvilke arbeidsoppgaver den inkluderer i og ekskluderer fra sitt handlingsrepertoar (Holmesland mfl., 2010). Videre knyttes faglig identitet til både personlighet, arbeidssted og utdanning (Miller, 2016). Faktorer som bestemmer den faglige identiteten, kan altså lokaliseres på individ-, organisasjons- og samfunnsnivå. Der finnes også betingelser som påvirker profesjonelles holdninger og handlinger knyttet til samarbeid (San Martín-Rodríguez mfl., 2005). På samfunnsnivå er blant annet utdanningssystemet sentralt, det er også de kulturelle systemene, som f.eks. de profesjonelles organisasjoner, som profesjonsmedlemmene inngår i. På organisasjonsnivå er blant annet verdier i organisasjonen, administrativ støtte og ressurser kanalisert til samarbeid viktige faktorer (Døving, Elstad \& Storvik, 2016; Røiseland \& Vabo, 2016). Organisasjonen eller tjenesteenheten de profesjonelle arbeider i, vil i tillegg legge betingelser som innebærer disiplinering av medarbeidere, det vil si at de lærer enhetens normer og regler for hvordan arbeidet skal gjennomføres (Christensen, Egeberg, Lægreid, Roness \& Røvik, 2015). På individnivå identifiseres faktorene faktisk vilje til samarbeid, tillit, kommunikasjon og gjensidig respekt (Mangan, Miller \& Ward, 2015).

Verdiene profesjonelle er bærere av, skapes kollektivt, i utdanningene, og knyttet til de sosiale systemene profesjonelle inngår i. Verdiene omfatter ikke nødvendigvis kunnskap om at profesjonelle er gjensidig avhengige av hverandre for å gjennomføre arbeidsoppgaver som ligger 
i skjæringsfeltet mellom ulike kunnskapsgrunnlag, og at det er i dette skjæringsfeltet at profesjonelle og tjenesteenheter gjennomfører sitt samarbeid. Å utvikle en positiv holdning til tverrsektorielt og -profesjonelt arbeid innebærer da at den enkelte profesjonelle identifiserer seg med egen profesjon, samt med andre profesjoner det skal samarbeides med, og at det forhandles med andre profesjoner om gjennomføring av arbeidsoppgaver. Forhandlingene føres om holdninger og handlinger, så vel som om faktiske arbeidsoppgaver - som er konkrete saker løftet fram for samarbeid. Slike forhandlinger krever at det eksisterer møteplasser for medarbeidere med ulike kunnskapsgrunnlag.

Verdiene i kommuneorganisasjonene ser ikke ut til å omfatte kanalisering av ressurser til samarbeid. Som det er vist til over, er domenekonfliktene tydelig til stede, og arbeidet med BTI - å opprette stafettlogg og være stafettholder - er ikke en del av de oppgavene alle aktuelle tjenesteenheter og profesjoner definerer som en del av sine arbeidsoppgaver. Det inngår dermed ikke i deres profesjonelle identitet. Samtidig viser materialet i undersøkelsen til at det heller ikke finnes møteplasser der profesjonelle kan forhandle om arbeidsoppgaver og konkrete samarbeid. Det legges altså ikke organisatorisk til rette for at slike forhandlinger skal finne sted. Et tydelig funn er at medarbeideres kunnskap om det bredere tverretatlige og -faglige arbeidet er blitt dårligere i perioden mellom 2012 og 2018. På svaralternativet «Jeg vet hvordan jeg får tatt opp saker i det tverretatlige teamet», er andelen som svarer positivt, redusert med like i underkant av 50 prosentpoeng, mens det på alternativet «Jeg vet hvem som er møteleder», er redusert med like i overkant av 30 prosentpoeng. I en kommentar som er avgitt i surveyen, kommer det fram at kommunen vedkommende arbeider $i$, har lagt ned sitt team:

Min opplevelse er at etter at vi ble en BTI-kommune, så har de tverrfaglige foraene vi hadde opprettet, blitt borte. Jeg opplever at BTI har skapt større avstand mellom tjenestene i kommunen, og vi kjenner mindre til hvem som jobber hvor.

I surveyen kommenteres det også på at de tverretatlige eller -faglige foraene ikke er kjent:

Jeg kjenner ikke til om det er egne tverretatlige fora i kommunen generelt, men vi innkaller til tverretatlige møter på skolen ved behov. 
I intervjuer ble det også pekt på at det tverrsektorielle og -profesjonelle arbeidet har ligget «nede» mens arbeidet med handlingsveileder og stafettlogg har pågått. Det har altså ikke vært oppmerksomhet mot at profesjonelle i visse tilfeller forholder seg til oppgaver som ligger i et skjæringsfelt mellom flere profesjonelle grupper og kunnskapsgrunnlag. Når samarbeid ikke er på agendaen i tjenesteenhetene, vil trolig individuelle og organisatoriske handlinger og prosesser styres av de verdiene og normene som er framtredende i det kulturelle systemet profesjonene inngår i. Da skapes det et lokalt rom, der de sektorspesifikke signalene fra statlig nivå blir rådende. Også på individnivå innenfor profesjoner er disse sektorspesifikke signalene kjente og innarbeidet, og trolig vil de styre profesjonelles syn på verdien av samarbeid.

Domenekonfliktene, altså overføring av uønskede arbeidsoppgaver til medlemmer av andre profesjoner, innebærer eksempelvis at barnevernet må konsultere andre tjenester manuelt fordi sakene som kommer til dem, ikke har logg, og det må forhandles lateralt om samarbeid. Skal samarbeid etableres, må tjenesteenhetene kommunisere direkte om aktuelle observasjoner for å gjennomføre dialog og diskusjon, og for å bli enige om intervensjoner for barn og unge og deres familier. Dette krever at de samarbeidende partene har et forum der de kan utvikle felles holdninger til målet for samarbeidet, samt til hvilke intervensjoner som kan fungere. Det kan se ut til at barnevernet involveres i domenekonflikter. Det blir involvert av andre kommunale aktører som burde være deres samarbeidspartnere, og det danner selv utgangspunkt for slike konflikter. I 2018 er det mange som opplever at det er greit å forholde seg til barnevernet, og på spørsmålet «Hvordan vurderer du samarbeidet med følgende tjenester i bekymringssaker?», er det 43 prosent som mener at samarbeidet med barnevernet er godt. Det er dessuten 18 prosent som mener det er meget godt (Helgesen, 2018). Intervjupersoner kommenterer også på dette, og viser til at det er gjort en ekstra innsats for å bedre samarbeidet med barnevernet. For eksempel er det gitt opplæring til barnehager i hvordan en bekymringsmelding skal skrives - hvilken informasjon den skal inneholde, og når den bør sendes. Da omtales også innslagspunktet for når det skal etableres stafettlogg knyttet til samarbeid med barnevernet. Samtidig kommer fortsatt kommentarene i spørreskjemaet om at 
barnevernet er lukket, implisitt at tjenesten framstår som lite interessert i samarbeid.

BTI kan formalisere regler og prosedyrer som skal tas i bruk i samarbeid, og handlingsveilederen kan fungere som en standardisering av kunnskap om tverrsektorielt og -profesjonelt arbeid. Domenekonfliktene medfører likevel at handlingsveileder og stafettlogg ikke får en standardiserende funksjon. Intervjupersoner omtaler dette ved å vise til at de arbeider hardt for å forankre BTI hos alle enhetsledere. De er ute i tjenesteenhetene og snakker om BTI, og de arrangerer møter for å fremme BTI som arbeidsmodell. Likevel er det mostand:

Jeg må gå med pekefingeren og tvinge det inn. Det å tydeliggjøre lederansvaret i

en forankringsprosess på et tidlig tidspunkt er nødvendig. (Intervju 3)

En prosjektleder reflekterte over dette i ettertid og sa at:

[...] vi hadde ansvarliggjort våre ledere sterkere og vært tydeligere hvis vi nå gjorde dette om igjen. (Intervju 4)

Slike utfordringer knyttet til styring og ledelse indikerer at BTI og verktøyene blir lite brukt. For å få et bilde av dette er det stilt spørsmål i surveyen om hvor kjent BTI, handlingsveileder og stafettlogg er i kommunene, og om kommunale respondenter har erfaring med å arbeide med BTI. Mange kommunale respondenter (89 prosent) kjenner BTI og vet at deres tjeneste arbeider med BTI, men det er færre som selv har erfaring som stafettholder (25 prosent). Barnehagelærere og helsesøstre svarer oftest ja på dette spørsmålet, relativt til antallet fra stillingskategoriene som svarer på undersøkelsen. Det er også disse stillingskategoriene som oftest oppgir at de har egen erfaring som stafettholder (Helgesen, 2018). Resultatene styrker de observasjonene som er gjort i tilknytning til svak styring og ledelse som medfører domenekonflikter.

\section{Transparens og digitalisering}

Handlingsveileder og stafettlogg er verktøy som skal styre strukturen og prosessene i BTI. Teoretisk sett vil slike verktøy gjøre det mulig å arbeide tverrsektorielt og -profesjonelt uten å ha fysiske møter for å gjennomføre 
konsultasjon og diskusjon om intervensjoner. Handlingsveilederne må imidlertid være oppdatert for at dette skal være mulig, og dette er ikke alltid tilfelle. Samtidig kommer det fram at informasjonen som ligger i veilederne, ikke er tilstrekkelig for å opprettholde et tverrsektorielt eller -faglig arbeid. En intervjuperson beskriver handlingsveilederen på denne måten:

Vi har laget en digital handlingsveileder. Det er en nettside med info, et åpent forum der alle innbyggerne kan gå inn og lese. Vi har ingen hemmeligheter. Der får de innsikt i modellen. Vi har samlet all info på én side. Der er det oversikt over telefonnummer, og alt er lett tilgjengelig. Var litt slik tidligere at alle lurte på hvordan det virket? Ting var ikke samlet, det lå litt her og der. (Intervju 2)

Digitalisering oppfattes som et sentralt trekk ved BTI:

Det er den elektroniske løsningen som gjør at dette er et nybrottsarbeid. Hvis man tenker på handlingsveileder, så har mange tjenester hos oss tatt den i bruk. Den er fin og strukturert. Men den beskriver den arbeidsgangen som i stor grad var til stede før vi startet prosjektet. (Intervju 5)

Sitatene viser til at handlingsveilederen ikke gir nok informasjon om trekk ved tjenesteenheter som vil være viktige for å få i gang samarbeid. Presiseringen av hvilket ansvar ulike tjenesteenheter skal ha i intervensjoner for barn og unge, eller hva som er gjennomført av tiltak, er utdatert. Det kreves altså fysiske møter i tillegg til at det føres logg, og det kan se ut til at disse møtene må tilrettelegges slik at tjenesteenheter og medarbeidere informerer hverandre. Å bare forholde seg til handlingsveilederen og stafettloggen har altså en ikke-intendert konsekvens, nemlig at tjenesteenheter og medarbeidere ikke blir kjent med andre enheter og deres fagområder. På spørsmålet om medarbeidere vet om deres egen tjeneste har en veileder, er det 73 prosent som svarer at de kjenner nedskrevne rutiner, og 50 prosent som mener at rutinene benyttes i stor grad. Samtidig er det 21 prosent som opplever at det er barrierer for å handle når de er i tvil om barn eller unge opplever utfordringer. 29 prosent av disse igjen mener det er vanskelig å vite hva de skal gjøre i slike situasjoner (Helgesen, 2018). Dette indikerer at handlingsveilederen enten ikke er oppdatert, eller at den ikke konsulteres og følges. Som det er vist til over, støtter kommentarer og intervjuer denne indikasjonen. 
Intervjupersoner mente også at det var motstanden mot BTI i organisasjonen som medførte at medarbeidere ikke konsulterte handlingsveilederen. De fikk ikke slike konsultasjoner inn i sine arbeidsvaner. Observasjonene det vises til over, tyder også på at medarbeidere ikke oppfordres til å ta handlingsveilederen i bruk. Hvis handlingsveilederen ikke er oppdatert, gir den ikke støtte til å vurdere innslagspunktet, altså når observasjonen som gjøres av barn og unges utfordringer, er av en slik karakter at det skal etableres stafettlogg, og andre tjenester dermed skal involveres.

Oppfatningene om stafettloggen som det gis uttrykk for, er også negative. En lærer omtaler det på denne måten i surveyen:

Jeg synes ikke stafettloggen er et hjelpemiddel for meg som lærer. Det er tungvint og tidkrevende og øker barrieren for å ta kontakt med foreldre fordi det blir så formalisert. Saker jeg ville tatt en telefon om tidligere, krever plutselig et møte og en logg.

Sitatet viser også til at loggen vurderes som tungvint, og en annen lærer ga en kommentar om at prosessene BTI satte i gang, var tungvinte:

BTI er tungvint og gjør at lærere ikke vil gjøre seg bekymringer på grunn av mer skrivearbeid. Det er et svært personavhengig system, og foreldre er skeptiske. Mange skoler har allerede gode systemer, og BTI blir da mer en belastning.

Noen mener altså at BTI gjør arbeidet mer tungvint enn tidligere.

Medarbeideres kunnskap om aspekter ved det tverrfaglige arbeidet ser ut til å være redusert i den perioden arbeidet med BTI har pågått. Likevel har kunnskapen om hvilke roller og hvilket ansvar ulike tjenester har for oppfølging av barn og unge det er knyttet bekymring til, økt fra 2015 til 2018, og mange medarbeidere vet også hvilke tjenester de kan kontakte for å få veiledning eller bistand vedrørende barn og unge. Det er færrest som vet dette i forbindelse med at familien barn og unge lever i, har økonomiske utfordringer, og flest som vet det hvis barnet eller den unge har lærevansker. Det er lite kunnskap om rollene til NAV, psykisk helsetjeneste og hjemmetjenesten (Helgesen, 2018). Tilgjengelig kunnskap om hva familiens økonomiske utfordringer betyr for barn og unges oppvekstmiljø, viser til at få medarbeidere på arenaer der barn og unge 
ferdes, kjenner til hva NAV kan tilby av hjelpetiltak. Det tyder også på at det er kontinuitet $\mathrm{i}$ hvilke problemstillinger medarbeidere har forholdt seg til før og etter at BTI er iverksatt, nemlig problemstillinger som ligger nær deres egen profesjonelle bakgrunn.

At det er lite kunnskap om hva andre tjenesteenheter tilbyr, er en antakelse som styrkes når man ser nærmere på hvem som deltar $\mathrm{i}$ tverrsektorielt og -profesjonelt samarbeid. Dette er ofte enhetsledere. Det indikerer at handlingsveileder enda ikke er blitt det verktøyet som gjør tverrsektorielt og profesjonelt arbeid kjent og tilgjengelig for alle aktuelle medarbeidere i alle samarbeidskommunene. I tillegg indikerer det at det enten er lite ønskelig eller ikke vurdert som hensiktsmessig å delegere nødvendig beslutningsmyndighet til medarbeidere, dvs. de myndiggjøres ikke til faktisk å samarbeide. I undersøkelsen er dette operasjonalisert $\mathrm{i}$ et spørsmål om enheten har drøftet hvilket ansvar den skal ha hvis den inngår i samarbeid. 51 prosent mener ansvaret er drøftet. Å drøfte det bidrar til transparens, samt til å forenkle selve det tverrsektorielle og -faglige arbeidet fordi flere sitter på informasjon, og den blir felles for hele tjenesteenheten, eventuelt alle aktuelle tjenesteenheter. Også laterale konsultasjoner med andre tjenesteenheter kan bli forenklet hvis slike drøftinger gjennomføres, og dette kan bidra til å skape et felles språk om tverrsektorielt og -profesjonelt arbeid. Et felles språk er nødvendig for å skape transparens omkring arbeidet.

Forenkling av samhandlingen via bedret informasjon og kommunikasjon er et av målene med å lage digitale arbeidsverktøy. Digitalisering kan skape transparens, og alle aktuelle medarbeidere, samt foresatte, kan lese veilederen og få informasjon om trinnene i BTI-prosessen. Hvem som skal kontaktes, hvorfor, og når i prosessen det skal gjøres, er åpent tilgjengelig. Det kan også være enklere for foresatte å kommunisere med stafettholder og følge med på loggen fordi de kan sitte hjemme og slå opp via sin egen datamaskin. Slik kan maktulikhet i relasjonen mellom kommuner og foresatte unngås - fordi alle i teorien kan være like informerte.

Men også i kommunikasjonen med foresatte har de elektroniske verktøyene begrensninger. Det er nemlig ikke alle tjenesteenheter som tar verktøyet i bruk, samtidig som handlingsveileder ofte ikke er oppdatert og loggen ikke ført. Å ta seg tid til å lese i veileder eller logg gir dermed 
ikke foresatte nødvendig informasjon eller innsikt i samhandlingsprosesser om tjenester som ytes til barn og unge. Samtidig kommer det fram i surveykommentarene at medarbeideren ikke alltid mener de samarbeider godt med foresatte, blant annet fordi foresatte ikke benytter loggen. De fysiske møtene må derfor fortsatt gjennomføres, for eksempel for å få samtykke fra foresatte. Det er samtidig uklart hvordan de fysiske møtene med familier gjennomføres. Respondenter har kommentert i surveyen at kommunale tjenesteenheter kan møte med opptil tre representanter hver, både enhetsleder, fagleder og pedagog.

Følgende kommenteres også av en surveyrespondent:

Møtene kan framstå med for mange fagpersoner i møte med sårbare familier. En massiv ubalanse i makt. Burde sortert bedre hvilke instanser som er aktuelle på forhånd. For mange får kjennskap til for mye.

Hvis det ikke på forhånd gjøres et arbeid med å fatte beslutning om hvilke personer fra de kommunale tjenesteenhetene som skal delta på møter med familier, og hvilken myndighet de skal ha, oppstår det maktulikhet mellom kommunens representanter og de foresatte. Slik maktulikhet bidrar ikke til transparens eller godt samarbeidsklima i viktige saker.

\section{Oppsummering}

Innledningsvis ble det stilt spørsmål om BTI vil kunne forenkle beslutninger om og tjenesteyting i gjennomføringen av tidlig innsats for barn og unge. For å diskutere dette ble det stilt tre spørsmål: 1) Hva er de organisatoriske betingelsene for tverrsektorielt og -profesjonelt samarbeid i kommunene? 2) Hvordan utformes tverrsektorielt og -profesjonelt arbeid knyttet til BTI, og hvilken kunnskap har medarbeidere om dette i egen organisasjon? 3) Medfører digitaliseringen at det blir transparens i det tverrsektorielle og -profesjonelle arbeidet med BTI?

Hva er de organisatoriske betingelsene for tverrsektorieltog-profesjonelt samarbeid i kommunene? BTI ser ut til å være iverksatt uten å være tilstrekkelig forankret hos aktuelle enhetsledere og i styringslinjen. I kommuner som har en tonivåmodell på sin administrative organisasjon, kan 
dette ha slått spesielt negativt ut - fordi enhetsledere kan ha oppfattet at de hadde et handlingsrom til ikke å ta BTI i bruk. Den kommunale styringslinjen fungerte dermed ikke optimalt for å legge til rette for at aktuelle tjenesteenheter kunne enes om å benytte ett verktøy for tidlig innsats. Dermed kan det se ut til at man i iverksettingen av BTI må ta i bruk hele styringslinjen, og at det bør være et nivå mellom rådmann og tjenesteenheter der samordning kan foregå, og som kan utvikle felles styringssignaler for alle aktuelle tjenesteenheter. Et slikt organisatorisk grep begrunnes også av at tiltak som har sitt utspring i helsesektoren, ikke nødvendigvis har legitimitet i andre sektorer. Det er påvist helseimperialisme f.eks. knyttet til folkehelse, der helsesektoren vil at konsekvenser for helse skal vurderes systematisk i andre sektorers planlegging og tiltaksutvikling (Synnevåg, Amdam \& Fosse, 2018). Å ta hensyn til slike effekter og hindre at tiltak vurderes negativt, krever at man fokuserer ekstra på styring og spesielt på planlegging som styringsvirkemiddel.

Hvordan utformes tverrsektorielt og -profesjonelt arbeid knyttet til BTI, og hvilken kunnskap har medarbeidere om dette i egen organisasjon? BTI, og andre verktøy som er i bruk i kommunene, er ofte iverksatt i den sektoriserte relasjonen mellom nasjonalt nivå og spesifikke kommunale tjenesteenheter. I den norske iverksettingstradisjonen er samordning et kommunalt ansvar og BTI ser ut til å bli iverksatt innenfor denne tradisjonen. BTI krever da at det er et utviklet og tydelig system for tverrsektorielt og -profesjonelt samarbeid på kommunalt nivå som modellen kan iverksettes innenfor, eller det må etableres et system samtidig som BTI iverksettes. Det så vi at ikke ble gjort. Tvert imot ble systemene for tversektorielt- og profesjonelt samarbeid, som var ulike former for team og samarbeidsforumer, bygget ned i perioden kommunene arbeidet med utvikling av BTI. Medarbeiderne som svarte på surveyene hadde dårligere kunnskap om dette ved slutten av iverksettingen enn de hadde før arbeidet med BTI startet. Dette resultatet var markant og trolig gjelder det for flere av kommunene som deltok i utviklingsarbeidet, ikke bare for dem med en to-nivå-modell på sin administrative organisasjon.

Medfører digitalisering at det blir transparens i det tverrsektorielle og -profesjonelle arbeidet med BTI? BTI var ikke i utgangspunktet et digitalt verktøy, det er kommunene som har deltatt i utviklingsarbeidet som har 
utviklet BTI til å bli digitalt. På den ene siden er argumentet for å gjøre dette at det var en styrke at det ble utviklet en digital veileder og logg som alle involverte aktører enkelt kunne få tilgang til. Handlingsveileder og stafettlogg er verktøyene som skal benyttes for å gjennomføre koordineringen eller samarbeidet og disse oppfattes som BTIs mest sentrale kjennetegn. På den andre siden ble disse verktøyene også BTIs svake punkt fordi veilederen i mange tilfeller viste til gårsdagens løsninger og ikke var oppdatert med ny informasjon. I tillegg tok ikke alle aktuelle tjenesteenheter BTI i bruk. Det innebærer at de to verktøyene som skulle forenkle informasjon og kommunikasjon både mellom kommunale tjenesteenheter, og mellom disse og brukere, ikke kunne benyttes som forutsatt. Da ble ikke BTI det transparente verktøyet som det var forventet at det skulle bli, hverken for de profesjonelle eller for barn og unge, samt pårørende som var involvert i saker.

\section{Konklusjon}

Selv om det kommer fram at det er utfordringer i den kommunale utviklingen og iverksettingen av BTI, uttrykker prosjektlederne at de nå er fornøyde med sine respektive BTI-systemer. De uttrykker samtidig at det tok mye lengre tid enn de hadde sett for seg å faktisk utvikle og tilpasse modellen til egen kommune. Det ble også sagt ganske tydelig at nå var valget tatt, og det var BTI som skulle være den framtidige samordningsmodellen for tidlig innsats i deres kommuner. Samtidig var det altså uforutsette utfordringer i arbeidet med å iverksette BTI i kommunene, og disse kan tilskrives siloorganisering og -tenkning i de enkelte statlige sektorene. Slike utfordringer kunne ha vært løst hvis f.eks. nasjonale myndigheter hadde gjort en utredning på forhånd, før prosessen med å utvikle og iverksette BTI ble satt i gang, for nettopp å avklare om det eksisterte formaliserte samarbeidsrutiner på noen tjenesteområder i kommunene. Slike burde bli tatt hensyn til i utviklingen av BTI. Utfordringene vi har sett at kommuner står overfor i forbindelse med at barn og unge lever i utsatte situasjoner, rettferdiggjør iverksettingen av sektorovergripende verktøy for å fange dem opp. Dette bør følges opp eller styres fra statlig nivå, slik at styringssignaler fra ulike sektorer kan samordnes overfor 
kommunene. Samordning er ikke bare et krav staten kan stille til kommuner, det er også et krav staten må stille til seg selv.

\section{Referanser}

Abbott, A. (1988). The system of professions: An essay on the division of expert labour. Chicago: University of Chicago Press.

Christensen, T., Egeberg, M., Lægreid, P., Roness, P.G. \& Røvik, K.A. (2015). Organisasjonsteori for offentlig sektor. Oslo: Universitetsforlaget.

Dent, M., Gestel, N.V. \& Teelken, C. (2007). Symposium on changing modes of governance in public sector organisations: Public Administration, 85(1) 1-8 Action and Rhetoric. London: Blackwell Publishers.

Døving, E., Elstad, B. \& Storvik, A. (2016). Profesjon og ledelse. I Døving, Elstad \& Storvik (Red.), Profesjon og ledelse. Bergen: Fagbokforlaget.

Helgesen, M. (2018). Bedre Tverrfaglig Innsats. En spørreundersøkelse til samarbeidende kommuner. NIBR-rapport 2018: Oslo: By- og regionforskningsinstituttet.

Helgesen, M. (2015). Bedre Tverrfaglig Innsats. 2. runde av en følgeevaluering. NIBRrapport 2015:24, Oslo: Norsk institutt for by- og regionforskning.

Helgesen, M. (2013). Bedre Tverrfaglig Innsats (BTI). Følgeevaluering. NIBR- rapport 2013:23, Oslo: Norsk institutt for by- og regionforskning.

Helsedirektoratet (u.å.): (http://tidliginnsats.forebygging.no/Nyheter/Bedretverrfaglig-innsats/).

Helsetilsynet (2009). Utsatte barn og unge - behov for bedre samarbeid. Rapport fra Helsetilsynet 5/2009.

Holmesland, A.L., Seikkula, J., Nilsen, Ø., Hopfenbeck, M. \& Arnkil, T.E. (2010). Open dialogues in social networks: Professional identity and transdisciplinary collaboration. International Journal of Integrated Care, 10(16).

Helsedirektoratet (2007). Fra bekymring til handling. IS-1455. Oslo: Helsedirektoratet. Mangan, C., Miller, R. \& Ward C. (2015). Knowing me, knowing you: Interprofessional working between general practice and social care. Journal of Integrated Care 2015; 23:62-73.

Marmot, M. (2015). The health gap. The challenge of an unequal world. London: Bloomsbury.

Miller, R. (2016). Crossing the cultural and value divide between health and social care. International Journal of Integrated Care, 16(4), 10. https://doi.org/10.5334/ ijic. 2534

Monkerud, L.C., Indset, M., Stokstad, S. \& Klausen J.E. (2016). Kommunal organisering 2016: Redegjørelse for Kommunal- og moderniseringsdepartementets organisasjonsdatabase. NIBR-rapport 2016:20, Oslo: By- og regionforskningsinstituttet. 
Barne- og likestillingsdepartementet (2017). Svikt og svik. Gjennomgang av saker hvor barn har voert utsatt for vold, seksuelle overgrep og omsorgssvikt, NOU 2017:12, Oslo: Departementenes sikkerhets- og serviceorganisasjon. Informasjonsforvaltning.

Peters, B.G. (2015). Pursuing horizontal management: The politics of public sector coordination. Lawrence: University Press of Kansas.

Power, C. \& Kuh, D. (2006). Life course development of unequal health. I: Siegrist, J. \& Marmot, M. (Red.) Social inequalities in health. New evidence and policy implications, s. 27-53. Oxford: Oxford University Press.

Raninen, J., Elgán, T.H., Sundin, E. \& Ramstedt, M. (2015). Prevalence of children whose parents have a substance use disorder: Findings from a Swedish general population survey. Scandinavian Journal of Public Health, 1-4. https://doi. org/10.1177/1403494815601525

Røiseland, A. \& Vabo, S.I. (2016). Styring og samstyring: Governance på norsk. Oslo: Universitetsforlaget.

Røvik, K.A. (1998). Moderne organisasjoner. Trender i organisasjonstenkningen ved tusenårsskiftet. Bergen: Fagbokforlaget.

San Martín-Rodríguez, L., Beaulieu, M.D., D’Amour, D. \& Ferrada-Videla, M. (2005). The determinants of successful collaboration: A review of theoretical and empirical studies. Journal of Interprofessional Care. Supplement 1: 132-147.

Stenmark, H., Bergström, E., Hägglöf, B., Öhman, A. \& Petersen, S. (2015). Mental problems and their socio-demographic determinants in young schoolchildren in Sweden, a country with high gender and income equality. Scandinavian Journal of Public Health 1-9. https://doi.org/10.1177/1403494815603544

Synnevåg, E.S, Amdam, R. \& Fosse, E. (2018). Intersectoral planning for public health: Dilemmas and challenges. International Journal of Health Policy and Management, 7(11), 982-992. 


\section{Om bidragsyterne}

Tone Alm Andreassen er dr.polit i sosiologi og professor ved Senter for profesjonsstudier, OsloMet - storbyuniversitetet. Hennes forskningsinteresser er organisatorisk reform og interorganisatorisk samarbeid. Hun har forsket på organisasjonsutfordringer knyttet til mennesker med livssituasjoner og helseutfordringer som krysset velferdsstatens organisasjons- og sektorgrenser, og på politikk- og tjenesteutvikling i samhandling mellom det offentlige og organisasjoner i det sivile samfunn. Hun er nå en av forskningslederne for INTEGRATE - et kjerneforskningsmiljø om samhandling for arbeidsinkludering.

Catharina Bjørkquist er førsteamanuensis i statsvitenskap ved Høgskolen i Østfold og PhD i statsvitenskap fra Karlstads universitet. Hennes forskningsinteresser er offentlig reformer, samordning av helse- og velferdstjenester og interorganisatorisk samarbeid. Hun har jobbet med organisering av tjenester, styring, organisering og ledelse i sykehus og digitalisering. Hun er leder for prosjektet ROPIT som studerer organisering av integrerte tjenester til mennesker med samtidige ruslidelser og psykiske lidelser (ROP).

Mona Jerndahl Fineide er førsteamanuensis ved Høgskolen i Østfold ved avdelingen for helse- og velferd og er knyttet til masterstudiet i Samordning av helse- og velferdstjenester. Hun har mange års erfaring fra kommunal helse og velferdstjeneste som profesjonsutøver og leder og har en doktorgrad i arbeidsvitenskap fra Karlstad Universitet. Hennes forskningsinteresser er styring, organisering og ledelse av helse- og velferdstjenester.

Gunnar Vold Hansen er professor ved Høgskolen i Østfold og har vært knyttet til masterstudiet i Samordning av helse- og velferdstjenester siden studiet ble opprettet i 2008. Han er utdannet cand. polit med hovedfag i administrasjon og organisasjonsvitenskap. Han har i tillegg 
en doktorgrad i Arbeidsvitenskap. Hans forskning har særlig vært rettet mot samordning av tjenester for mennesker med rus- og/eller psykiske lidelser, samt domfelte som soner dom i fengsel.

Marit Helgesen er professor ved Master i samordning av helse- og velferdstjenester ved Høgskolen i Østfold. Hun har en $\mathrm{PhD}$ fra Institutt for administrasjon- og organisasjonsvitenskap, Universitetet i Bergen og har arbeidet ved By- og regionforskningsinstituttet, OsloMet. Helgesen arbeider med prosjekter om samordning av tjenester for barn og unge, folkehelse samt digitalisering og profesjonelle arbeidsprosesser.

Helge Ramsdal er statsviter med hovedfag i Organisasjons- og administrasjonsvitenskap, og professor ved Avdeling for helse- og velferd ved Høgskolen i Østfold. Han er tilknyttet masterstudiet i Samordning, og hans forskningsinteresser dreier seg om helse- og velferdspolitiske problemstillinger, og utvikling av organisasjons- og ledelsesformer i sektoren. Han har de senere år arbeidet med endringer i sykehusstruktur, og utvikling av tiltak og tjenester til mennesker med rus- og psykiske lidelser.

Mia Vabø er dr. philos og forsker I ved NOVA, Senter for velferds- og arbeidslivsforskning ved OsloMet. Hun har i en årrekke forsket på forholdet mellom styringsideologiske trender, organisering og praktisk omsorgsarbeid. Vabø har deltatt i en rekke internasjonale forskningsprosjekter og har omfattende erfaring som forskningsleder og prosjektleder. Hun leder for tiden et større dansk/norsk prosjekt, CONTEXT, som retter søkelyset mot nye idealer i helse- og omsorgstjenestene med vekt på integrerte, person-sentrerte tjenester.

Erlend Vik har en mastergrad i sosiologi fra NTNU. For tiden er han doktorgradsstipendiat ved Høgskolen i Molde, og ansatt på avdeling for økonomi og samfunnsvitenskap. Avhandlingen er en studie om hvordan helseledere, forskning og politikk forstår og forholder seg til fenomenet samhandling. Teoretisk er avhandling forankret i Niklas Luhmanns systemteori og en forståelse av helsetjenesten som funksjonelt differensiert. 
Turid Aarseth er cand. polit. fra Universitetet i Bergen og arbeider som professor ved Høgskolen i Molde, Avdeling for økonomi og samfunnsvitenskap. Hun har lang erfaring fra kommune- og helsetjenesteforskning og er særlig opptatt av desentralisering av velferdsstaten og horisontal samordning. 
